\title{
André Brink, Dissenter
}

\author{
by
}

Shelley May Dixon

\begin{abstract}
A thesis
submitted to the Victoria University of Wellington in fulfilment of the requirements for the degree of

Doctor of Philosophy in English Literature
\end{abstract}

Victoria University of Wellington

2005 
"the urge to say no"

(André Brink Contrary 362). 


\section{Contents}

Acknowledgements $\quad$ iv

Abstract

Introduction:

The Birth of Afrikaner Dissidence: A Challenge from Within the Laager

Chapter 1:

The Origins of Political Dissent in The Ambassador

Chapter 2:

Brink, Politics and the Censor - the Power of the Word in Looking on Darkness

Chapter 3:

Black/White Relations in An Instant in the Wind and A Dry White Season

Chapter 4:

Exile and the Exilic Position: The Coloured Perspective in

The Wall of the Plague

Chapter 5:

Looking Within: Afrikanerdom \& White Guilt in The Ambassador,

On the Contrary and Rumours of Rain

Chapter 6:

Metafictional Challenges to Truth in On the Contrary

Chapter 7:

States of Emergency in States of Emergency

Chapter 8:

Revisiting History: Re-mythologising South Africa in

The First Life of Adamastor, Devil's Valley and A Chain of Voices

Chapter 9:

An Act of Terror and Violence as Protest

Chapter 10:

Accusations of Misrepresentation and Appropriation: Female Representation in

A Portrait of Woman as a Young Girl, Imaginings of Sand and The Other Side of Silence

Conclusion:

The 'New' South Africa, The Rights of Desire and Before I Forget

Appendix:

Selected photographs from A Portrait of Woman as a Young Girl

Works Cited 


\section{Acknowledgements}

The completion of a project of this nature would not have been possible without the inspiration, support and encouragement of many people. To all of those who have assisted in any way, I offer my sincere thanks.

Grateful acknowledgement is made of funding from the VUW Postgraduate Scholarship.

I would especially like to thank the academic supervisors who have been involved in this project. My former academic supervisor, Dr. Kim Worthington, not only inspired the research on which this thesis is based, but has generously and patiently provided ongoing advice and encouragement. Her South African knowledge has been as invaluable as her theoretical expertise.

Likewise, my current academic supervisor, Dr. James Meffan, has been an ongoing source of advice, resources and support. His intellectual abilities and his specific strength in the realm of literary theory have inspired and motivated me. His input has stretched my thesis in new and challenging directions. Further, his belief in my ability to finish this project has often been far stronger than my own, and for his faith in me, I am especially grateful.

Dr. Jane Stafford joined my group of academic supporters at a late stage. She was given the onerous task of acting as a second reader and editorial advisor. Her willingness to do so is much appreciated, as were her insightful and helpful comments. Her involvement has resulted in a much improved thesis.

I would also like to thank the School of English, Theatre and Film at Victoria University, without whose support, funding and other resources the thesis would never have reached completion.

My family and friends have been patient and supportive while the agonising process of research and writing has transpired. I also offer them my appreciation for their constancy and faith.

I am especially grateful to John, without whose support and belief in my abilities I would never have been able to begin this project.

Finally, I would like to thank my parents, who instilled in me an appreciation of literature from an age beyond the reach of my memory; this is a lifelong gift which I will continue to cherish.

Shelley Dixon

Wellington

February 2005 


\begin{abstract}
This thesis provides a survey of the novels written in English by Afrikaans author, André Brink. It contextualises these texts in terms of the political and social issues of the era in which each was written. Specifically, it examines the ways in which the novels stand as a dissenting body of work against a particularly prescriptive and preclusive environment, challenging the racially prejudiced practices of apartheid South Africa and, later, challenging other forms of oppression in the post-apartheid nation. One of the most interesting aspects of Brink's work, I argue, is that his challenge comes from within the Afrikaner community. Discussion of the novels is concerned not merely with the literary treatment of a range of themes, but also with the worldly implications of this treatment, the ways in which Brink considers his questions about, and challenges to, authoritarianism. I argue that the oeuvre demonstrates Brink's developing social and political conscience, a series of 'rebirths' in which the artist is prompted to reconsider his role as an artist.

I examine Brink's works from a number of perspectives and in relation to a number of central themes. My approach in looking at the oeuvre from different angles is highly suggestive of the problem as it plays out for Brink: he is unable to straightforwardly resolve the themes he treats, but refuses to concede defeat or retreat from the central issues. This, I suggest, is one of the most significant aspects of Brink's work - his willingness to continually reassess his environment and his response to it. He returns to favourite themes and considers the same issues from new perspectives and with new knowledge. The irresolution which defines his treatment allows the possibility for future investigation, a further dialectic interrogation of the issues in a new context.
\end{abstract}

The works also trace the author's 'cultural conversation', a dialogue which both records and challenges the prescriptive and preclusive environment of apartheid South Africa. I extend this examination to include the post-apartheid novels, discussing the situation of the dissenting artist for whom the most obvious forms of authoritarianism have become defunct. Essentially, the thesis investigates the politics of writing as dissident politics and considers whether Brink's dissident project is a success and, indeed, whether dissent itself is viable. 


\section{INTRODUCTION}

\section{The Birth of Afrikaner Dissidence:}

\section{A Challenge from Within the Laager}

"at least we have learnt this much from Marxism, that we accept our involvement

- even our implication in our social context and in history"

(Isidore Diala, "Political Limits" 7). 
Brink claims to have been "born on a bench in the Luxembourg Gardens in Paris, in the early spring of 1960." He continues: "I had been born earlier too, of course; and after that cool bright spring morning in Paris I experienced several other births as well, some easy, some traumatic, but none quite so decisive as that one" ("Introduction: A Background" 29). ${ }^{1} \quad$ His first re-birth symbolises a striking transformation in his ideological beliefs. Born in Vrede, a small village in the Orange Free State province in South Africa in 1935, Brink spent his adolescence within a strictly conservative Calvinist Afrikaner rural environment. The first seven years of his tertiary education were spent at Potchefstroom University, a 'Dopper' (CalvinistReformed) institution of which Paul Kruger was a founder. In 1959, he embarked on postgraduate work in comparative literature at the Sorbonne in the University of Paris (Ayling 46). This geographical dislocation demarcates the point at which Brink began to question his social inheritance, challenging the ideological attitudes and implications of his homeland, and indeed the very basis on which his identity was constructed. In France, he met black students, lawyers and teachers with whom he could interact "on equal terms": prior to this, he claims that the only black people he had met in South Africa had been labourers or domestic servants ("André Brink Talks" 1). He was also exposed to a range of philosophical and literary theorists and authors who were instrumental in challenging the strictures and insularity of his Afrikaner upbringing. He notes, "suddenly I found myself in that great metropolis where every single thing I had always taken for granted had to be tested, explored, validated - or rejected" ("Introduction: A Background" 32): "tribal customs and taboos, religion, relationships with groups and individuals and with the country itself, ideas, a view of history, plans for the future" (Ambassador 9). He became interested in the theories and literature of many avant garde authors of the time who were to influence his work, most notably Albert Camus, Jean-Paul Sartre and Alain RobbeGrillet. Specifically, he was inspired by Camus' view that humankind is in a constant state of rebellion against imposed conditions ("André (Philippus) Brink" 389). It was

\footnotetext{
${ }^{1}$ Nadine Gordimer notes that this type of re-birth is an experience shared by many young white South Africans. "They are born twice: the second time when, through situations that differ with each individual, they emerge from the trappings of colour-consciousness that were as 'natural' to them as the walls of home or school" ("English-Language" 110).
} 
also in Paris that his interest in existentialism was initiated, a set of understandings which permeates Brink's works to this day.

However, Brink's sense of release, engendered by his immersion in the cultural fecundity of Paris, soon came to an end. In 1960, the Sharpeville massacre in South Africa initiated a re-assessment of his homeland and of his place in it: the incident marked a turning point in the history of the South African resistance movement which is mirrored in Brink's own response to the event. He began a sustained attempt, through writing, to change the political, social and moral environments which allow such tragedies; his growing political awareness ultimately drew him back to South Africa.

The history of South Africa is one in which the struggle between British and Dutch control is clear. What is not highlighted is that South Africa was already occupied before colonisation: the conventional "white"2 rendition of history ignores the historical contribution and narratives of the majority of the population. From the first Dutch colonist to the 1948 election of 'the apartheid government', the National Party, and beyond, vast lacunae exist in the historical record of South Africa and South Africans. As in many colonial contexts, the voices of the colonised, the nonwhite inhabitants of the land, are ignored, refuted, silenced or forgotten. Further, the specifically patriarchal rendition of white history occludes female experience(s). These silences surrounding otherness are the focus of Brink's texts and the central means by which he challenges the dominant voice of the Afrikaner establishment.

\footnotetext{
${ }^{2}$ The use of politically correct terminology to describe the various racial and ethnic groups of South Africa is problematic. The practice of labelling different groups, and the dichotomous pairing of 'black' versus 'white' (or their various euphemisms) is contrary to the moral intent of both Brink's oeuvre and of this thesis while simultaneously denying those who deem themselves members of neither group. Similarly, the use of terms which denote another by describing that which is not (e.g. 'non-white') are also inherently problematic. Invariably, the creation of new terminology designed to avoid negative associations soon becomes tainted with the same connotations of the originals. I have chosen, therefore, to use the most common terms of 'white', 'black' and 'coloured', with full cognisance of, and apologies for, the problematic nature of each. The term 'coloured' is commonly used in South Africa to describe people of mixed racial descent and, as such, I will also use it in my
} 


\section{The Sestigers}

The European experience, the social commitment which was to become so integral to Brink's work, and the experimentation in form which is increasingly evident in his writing were foundational elements shared by a group of Afrikaans writers named the Sestigers. Brink was a founding member and spokesperson for the group, which included writers such as Hennie Aucamp, Chris Barnard, Breyten Breytenbach, Abraham H. de Vries, Ingrid Jonker, Elsa Joubert, Etienne Leroux, Jan Rabie and Bartho Smit. In briefly discussing the role of this group in (dissident) Afrikaans literature, I will attempt to place Brink's contributions in historical context. His work of this time demonstrates the formal legislated censorial impediments to literary freedom which Brink was the first Afrikaner writer of note to experience and challenge. The consequent need for resistance to these impediments will also be explored, alongside Brink's realisation and adoption of the dissident role available to him in this literary realm. In outlining the literary and political significance of the era of the 1960s, and the consequent literature of Sestig, I hope to offer an outline of the contextual roots from which Brink's thematic and technical dissidence derive, an understanding intended to enrich the analyses which follow.

Adopting their name from the decade in which they operated, the Sestigers, (literally "the sixtiesers"), a collection of poets and novelists, challenged the conventional treatment of South African themes and became the enfants terribles of the Afrikaner literary establishment. Brink's manifesto for the group laid the foundations for a new era of South African literature:

First: Freedom, responsibility, honesty, joy in creation, to lay open repressions and taboos, to break down the false hierarchy and recreate the equivalence (of life).

Secondly: The development of technique, experiment, word usage.

discussion. Where appropriate, further distinctions will be made between various groups such as the 'indigenous' tribes and the 'Afrikaners'. 
Then: No tolerance or mercy for the inferior or the hypocritical; truth to the spirit of our time (qtd. in Cope 126).

Brink notes that each of the group's members had spent some time in Europe, particularly Paris, and had returned to what appeared a "stifling and parochial" atmosphere in South Africa. In response, they began writing in an alternative literary mode, inspired by the European model (Brink "Interview by Jim Davidson" 27).

In literary terms, the freedom of experimentation of the 1960s, exhibited in the European literature of the era, and the correlative questioning of existence in philosophical circles represented a threat to the hegemonic stability of authority. Apartheid South Africa, founded on principles of uniformity and adherence to accepted values, represented an antithesis to the experimental and progressive ideals of the era. Consequently, the South African authorities were to censure such aberrations from the accepted norm, labelling the literature of Sestig immoral, and staging an ongoing battle to retain the circumscribed representation of existence found in (the majority of) conventional South African literature. ${ }^{3}$ In these terms, dissident artists operated in what Brink describes as a state of moral "siege", in direct confrontation to the state (See Brink "The Writer").

Brink outlines the Sestiger objective "to query long established social values" (Malan 8) and "revolt against Afrikaner hegemony" ("South Africa" 484) which suppressed the individual within the strictures of normative discourse. In these terms, the movement necessitated a reassessment not only of the tenets of Afrikanerdom, but also of the bases of Brink's sense of self-identity. Evidently, the initial Sestiger reaction to the establishment was an attack on a certain type of hegemony. Their dissent was self-focussed in that it demanded Afrikaner self-emancipation, as the Sestigers sought identities, and the literary representation of those identities, beyond the traditional restrictions of Afrikanerdom. ${ }^{4}$ Therefore, the initial Sestiger revolt

\footnotetext{
${ }^{3}$ The censorial impediments to literary creation, and the means by which these impediments were overcome will be discussed further in chapter two.

${ }^{4}$ Brink's later work demonstrates a development beyond this self-centred conceptualisation of dissent to a cross-cultural understanding of hegemony. This progression will be delineated in later chapters.
} 
involved claiming an individual, rather than a collective, authorised voice (Wren 29); the hegemonic values of die volk required examination and refutation, in order to allow alternative individual choices regarding issues such as religion, morality and politics. The normative discourse on which apartheid South Africa was founded and survived revolved around an archetypal Calvinist male Afrikaner whose ties to his church, family, volk and to the National Party circumscribed the manner in which almost every aspect of his life was conducted. Undermining this volk-mentality, therefore, necessitated a re-assessment of each of these belief systems. The Sestigers focussed on issues of religion and morality, employing alternative theologies and secular beliefs, and questioning the authority of those who prescribe morality for the masses.

In literary terms, the Sestiger re-evaluation represents a literary renewal. Traditional, accepted modes of narrative were rejected in favour of new forms: Sestig was as much characterised by its willingness to engage in experimentation as it was by its concern with new themes. "Initially the Sestigers presented a revolt against among other things - the sort of literature acceptable as 'art' [...]: a literature of drought and poor whites. And so the new movement became, partly, a movement away from the 'typically South African' in order to explore the 'universal', the 'human"” (Brink "Position" 13). Thus, experimentation in genre and form paralleled thematic exploration. The conventional realism associated with traditional Afrikaner literature $^{5}$ was subsumed by more imaginative forms, as thematic concerns widened in scope.

Postmodernist theory, which was circulating in Europe during this time - the 1960s - also influenced the writers of this group. Postmodernist strategies were soon to become integral components in the works of Brink and, most specifically, Breytenbach. However, the adoption of such theories raised questions concerning the political issues of the era and the role of dissidents who responded to these. As Ampie Coetzee notes of the time:

\footnotetext{
${ }^{5}$ See J. M. Coetzee's White Writing: On the Culture of Letters in South Africa.
} 
[t]he awareness of the literary discourse in Europe and America, and the necessity of being part of it - for writers are also citizens of the world - of course led to tremendous contradictions. How can a post-modern mode, with the word purely a signifier, be a weapon against a dictatorship of evil? To some the answer lay in physical action, in becoming an activist in the struggle, as in the case of Breytenbach; to others it lay in representative writing - i.e. old-fashioned realism: the only way to reach the hegemony. Their books were banned, as happened with Brink and Leroux. (107)

Coetzee's suggestion that Brink's work is realist is apparently at odds with my reference to its postmodemist tendencies. While my primary concern here is with Sestig and, most specifically, with the work of Brink, rather than postmodernism, a brief response to Coetzee's claim is necessary in the context of my claims regarding the relevance and significance of his oeuvre. Clearly, many aspects of Brink's work are realist in nature, depicting credible characters, situations and contexts. However, Brink also makes extensive use of postmodernist techniques such as self-reflexivity, parody and the textualisation of the world, in order to highlight the constructed nature of the text and to undermine its author-ity. In States of Emergency and On the Contrary, for example, Brink uses postmodernist strategies which prompt the reader to read against the grain of the text. ${ }^{6}$ In each case, Brink's dissident challenge to authoritarianism is reflected in the textual disruption of author-ity. Thus, to categorise Brink as either realist or postmodernist is too simplistic: rather, he adopts (and discards) techniques from both fields, as necessary. This co-existence of two apparently dichotomous literary techniques appears irreconcilable, and yet Brink balances the two with skill. Postmodernist tendencies are increasingly evident over the course of his oeuvre as he investigates diverse ways of launching his dissident challenge to author-ity.

Despite the innovations of the Sestig movement, there are a number of critics who dispute the significance of the Sestigers as a social and political force or who

\footnotetext{
${ }^{6}$ For further examination of Brink's postmodernist techniques, see Dixon's Shouting Against Silence: André Brink's Voices of Truth.
} 
emphasise the limitations of their political motivation. Marianne de Jong, for example, admits that Sestig was "a literature of protest, and this protest [...] was also political". However, she hastens to add that their "raison d'être" was not merely political, but rather one facet of their protest against "a conventionalism peculiar to Afrikaans and Afrikaner culture". Further, she explains that their dissident stance was based primarily on resistance to the Afrikaans precept that the artist should espouse the ideological 'truths' of Afrikanerdom; she argues that the Sestigers reserved artistic licence to produce works beyond these restraints, art that was "purely functional in the modernist sense" (de Jong 250). In summary, she describes the discursive formation which produced the Sestigers as Afrikaner "self-concepts", listing several central aspects of Afrikanerdom which, she claims, prompted the development of the particular stance adopted by the Sestigers. These elements include the cultural need for innovation; adoption of a Western or Eurocentric literary aesthetic; sexual conservatism and moral parochialism and apartheid "as a discourse not only of political opportunism and immorality, but, within the Afrikaans cultural field at the time, also as an anti-intellectual discourse of control and indoctrination" (de Jong 251). Echoing Foucault's claim that power produces its own subversion (Discipline and Punish), she suggests that the above listed formations "were produced within a field of power relations which link protest with the very thing protested against: Afrikaans sexual, literary, cultural, moral and political conventionalism" (de Jong 251). In these terms, Brink works against that which has formed him, representing an enfant terrible in the Afrikaner community. $\mathrm{He}$ exemplifies Foucault's dictum in that he is both a product of his historical moment and the reaction against that moment.

However, Nadine Gordimer redefines the role of the Sestigers in the cultural environment of their time, criticising their work in terms of the conservatism later cited by de Jong. Gordimer asserts that although the Sestigers "challenged with sexual candour and religious questioning, taunting the church and the Afrikaans

\footnotetext{
${ }^{7}$ Herein, I believe, lies one of the seeds of Brink's obsessive concern with the role of the artist, and of art, to be further discussed throughout the thesis and most specifically in the concluding chapter.
} 
Academy of letters" and experimenting with literary form, "the evidence that not one of them published anything that was banned shows how they turned away, astonishingly, from the deepest realities of the life going on around them." ("EnglishLanguage" 112). ${ }^{8}$ Criticism as to the group's effect and motivation is also launched from within: Breyten Breytenbach, a poet and artist whose work has been aligned with the Sestigers, claims that the attention paid to the group "helped entrench the reactionary forces in the country". The reason, he argues is twofold. First, debate centred on the group distracted the public from more significant political issues such as the suppression of black political parties, widespread poverty and the militarisation of the country. Second, an illusion was created in which the dissidence of Sestig (and, in later decades, of white writing in general) was touted as an effective, influential method to alter the nation's political future. Breytenbach counters claims as to the efficacy of Sestig as a tool of change, suggesting that the Sestigers merely endowed "the Afrikaner establishment with a greater suppleness to resist real transformation": he argues, "The tragedy is that with the pretensions of being 'open' we closed more doors, erected new walls, blinded more eyes". In summary, he suggests, "White writers - of the 'liberal kind' - are in reality just getting a personal kick out of flaunting some tribal taboos" (True Confessions 355). Breytenbach's cynical critique suggests that not merely Sestig, but all white writing is an ineffective tool of dissent.

As my concern with the Sestigers is solely in terms of their literary association with Brink, a lengthy debate as to the relevancy and importance of Sestig as a movement is beyond the scope of this thesis. I will, however, defend Brink's work as representative of this literature before considering the nature and value of a contestational position per se - in raising some of the issues pertaining to a dissident stance, I hope to construct a method of enquiry by which to examine Brink's works. In general terms, there is some value in each of these critics' claims, which fall into two distinct categories. The first group, which includes de Jong, focuses on the

\footnotetext{
${ }^{8}$ Gordimer does, however, acknowledge Brink's later political engagement in the $1970 \mathrm{~s}$, and the subsequent banning of his novel Looking on Darkness.
} 
manner in which the movement was a byproduct of a certain era, a natural progression in literary and political terms. The second, including Gordimer and Roberts, focuses on failures in the Sestig literature itself, failures which they claim illustrate its inefficacy as a tool of dissent.

These observations, however, focus on specific aspects of Sestig, to the exclusion of other, equally relevant, considerations. The natural progression towards dissent which de Jong claims, for example, gives no value or acknowledgement to individual artists who choose to dissent. It is my contention that much of the political impact of such literature lies in an author's adoption of a dissident stance, an effect both separate from, and intimately linked to, the literature's political content: the perspective from which the literature originates is as critical as its content. The risks and responsibilities associated with the dissident artist's choice, which affect the ultimate artistic product, are not taken into consideration in de Jong's model. This lack in her argument leads to a consideration of the critique by Gordimer and Roberts who focus on the content of the literature. As they note, Sestig is limited in scope, as Brink himself has argued. However, it is my contention that the literature contains the original kernels of dissent which are later expanded to challenge more specific political themes. This claim also counters, to some extent, Breytenbach's criticisms as to the limitations in scope of Sestig, a focus which distracts from other elements worthy of critique. As to his concerns regarding the use of Sestig as a tool of the establishment used to "resist real transformation", this claim is also countered by later developments in the writing of those originally labelled Sestigers. In each respect, the criticisms of these various critics are negated when the work of the Sestigers is viewed as the initial step in an ongoing and progressive seditious literature. The criticism launched against Sestig is, therefore, limited in its conception of the movement as a separate, enclosed entity: I argue that it should rather be viewed in similar terms to Brink's Sestig, as originating texts from which future political engagement develops. 
Despite the above criticism as to the inefficacy of the Sestigers as a politically dissident force, the manner in which literary techniques and themes opened up a whole range of new possibilities from this point onwards is evident. Arguably, the Sestigers movement demarcates an era in which Afrikaans writers began to awaken from their confinement and explore possibilities beyond the strictures of the authoritarian regime. Brink notes, "the generation of the Sestigers broadened the base of contestation in Afrikaans literature" ("Introduction: A Background" 26), challenging the very heart of an institution which had traditionally refuted such challenge, innovation, or choice. Summarising the collective work of this group, Brink highlights its "attempts to emancipate Afrikaans fiction of the time from its colonial restraints by introducing trends of thought and technique then in vogue in Europe and by breaking down taboos in the field of religion, ethics, sex and even narrative technique then prevalent in Afrikaans literature" (Ambassador 9). Speaking of the political effects of the movement, he qualifies,

[a]lthough there was little overt involvement with politics, the movement had surprising political side effects, as the questioning of Afrikaner morality and religion contributed towards a breakdown in the stranglehold of the authorities on the minds of the younger generation. As such, it paved the way for a later wave of fiction which was to involve itself more explicitly with the sociopolitical scene in South Africa and of which my novels from Looking on Darkness onwards formed a part. (Ambassador 9)

As Brink claims, this contestation is evident in his literature of the time, and is more fully developed over the course of his literary career.

For the first time, the Afrikaans-speaking public was privy to alternatives in terms of literary style, thematic content and linguistic ingenuity. This recorded account of alternative forms encouraged a new generation to contest restriction: "[b]reaking literary taboos was merely a symptom of a whole new era of political thinking" (Brink, "The Breytenbach File" 6). Brink notes of the Sestigers,

the impact of their renewal went far beyond the frontiers of literature. Their work became, first, a cultural, then a political phenomenon. Social attitudes 
within Afrikanerdom are assessed, even today, on the basis of whether a person is 'for' or 'against' the Sestigers. And this applies as much to people who have read their work as to a multitude who haven't. The ripple effect has even gone beyond Afrikanerdom itself: to many English speakers in the country and, even more significantly, to a large number of coloureds and blacks (who have never read a word of the Sestigers) this work has come to signify a revolt against an entire oppressive system. ("Writers and Writing" 45)

His claim is premised on the notion that the political structure of the country was founded on the very hegemonic beliefs questioned in Sestig. In undermining the normative discourse of the authorities in both religious and moral terms, Sestig deconstructs the foundational elements of the political system exemplified in apartheid. In these terms, the ties between religion, morality and politics suggest the implicit political dissidence of the Sestigers and are therefore crucial to discussions regarding Brink's early works, prior to his overt political dissidence.

\title{
Textual Context
}

\author{
"a text within the texture of the world" \\ (Brink Reinventions 19).
}

Brink's contestation against various restrictive models extends beyond the years of the Sestiger movement, however. Reflecting social and political contexts spanning more than four decades, his texts also return to earlier historical periods in order to comment on the origins of contemporary situations. Throughout the oeuvre, the specific social and political contexts in which each novel is created have a significant effect on the literature which results. 
There is a growing and significant body of literary criticism surrounding Brink's work, both within South Africa and worldwide. However, a brief survey of a selection of recent material will demonstrate both the limitations of the current critical analyses, and will also suggest the instigation for my own resolve to provide a more complete overview of Brink's oeuvre, including some discussion as to the development over the course of the oeuvre. Recent contributions to the literary discussions surrounding Brink's work include Jochen Petzold's Re-imagining White Identity by Exploring the Past: History in South African Novels of the 1990s, with a section entitled "André Brink and the Alternative Past". This text is helpful in its deconstruction of South African history and Afrikanerdom; however, like much of the analyses of Brink's work, it focuses on a limited number of the author's works in this case merely three - neglecting the remainder of the oeuvre published before 2002. Sue Kossew's Pen and Power: A Post-colonial Reading of J. M. Coetzee and André Brink would appear to resolve this problem of limiting the discussion to a select number of texts; the first full-length text to discuss Brink's work, Kossew provides an overview of the texts up to the date of publication. However, this 1996 text is now dated, and, understandably fails to address post-apartheid issues adequately. Furthermore, like many of its counterparts, the discussion of Brink's work is made in conjunction with that of one of his contemporaries, J. M. Coetzee, a decision which clearly alters the focus of the discussion.

Other recent dialogue includes Nicholas Wroe's 2004 interview "Out of the Laager" and Mélanie Joseph-Vilain's "Writing Women Back into History: Magic 
Realism in André Brink's Imaginings of Sand". Louise Viljoen's "Civilization and Wilderness: Identity in André Brink's An Instant in the Wind..." is also useful, as is Isidore Diala's “Nadine Gordimer, J. M. Coetzee and André Brink: Guilt, Expiation and The Reconciliation Process in Post-apartheid South Africa". However, again, the scope of these discussions is limited; the nature of articles is that they must focus on a very small number of topics and texts. While the material listed above introduces many of the issues I will be concerned with in my analyses, it is my intention to delve more fully into these topics, and to discuss them with regard to the overarching nature and concerns of Brink's oeuvre. It is also my resolve to update the current analyses of Brink's work by providing a more complete analysis of the post-apartheid works. I will also consider the changing role of Brink as a dissenting voice over the course of his oeuvre, a discussion which I believe has not been undertaken in any depth thus far, and to place his complete oeuvre to date within various relevant social, political and historical contexts.

In order to trace the relationship between the conditions and results of any particular novel, a dual textual and contextual approach will be undertaken with regard to Brink's oeuvre. As contexts alter, so too does Brink's literary response to the issues of his age; this thesis does not, therefore, trace a single line of argument throughout Brink's work, but identifies a series of socio-political concerns and examines the varying treatment of these themes throughout Brink's work. This textual/contextual treatment is determined by Brink's own self-proclaimed concern with the literary representation of South Africa. The etymological derivation of the word text gestures towards the iterative relationship of the textual: 'textus' describes a weaving, woven cloth, or web, prefiguring the term 'textile' (Brink "Transgressions" 
12). ${ }^{9}$ Thus, textual interplay, in which terms such as pretext, subtext, context and intertext figure, may be metaphorically imaged as a weave of fabric in which each of the strands is both independent, but also embedded in the whole. This 'fabric' metaphorically portrays the relational positioning of text and context discussed in this thesis. The fabric metaphor also gestures towards the manner in which individual and national narratives are interwoven, and thus South Africa as a nation may be envisaged as a series of texts, each of which may be analysed in literary terms. Brink's understanding of his spatial, historical and social milieus - as a series of narratives - is both the driving force behind this particular approach and also a central aspect of the debate which follows. The iterative relationship foregrounded in Brink's texts, therefore, speaks not merely within a literary realm but also in contexts such as the political, social and historical.

Such a mode of investigation is neither unique in the realm of literary criticism, nor recently envisaged: "Numerous critics, from very different perspectives, have [...] urged us to acknowledge that literature is situated within a web of historical conditions, relationships, and influences" (Gallagher ix). ${ }^{10}$ Gallagher claims that, "[e]xamined within historical, social, and political contexts, the formal qualities of a work of literature have new significance" (14). Her seminal work on the literature of J. M. Coetzee includes a booklength study, A Story of South Africa: J M Coetzee's Fiction in Context. Introducing this text, she notes

[w]ithout denying that his novels speak of profound, universal themes, I wish to examine Coetzee's fictions in terms of their conditions in and consequences for South Africa. Coetzee's work is able to transcend its historical situation only because it is in the first place linked to that historical situation. This

\footnotetext{
${ }^{9}$ The metaphor is borrowed from Roland Barthes who states, " $\left.t\right]$ ext means tissue; but whereas hitherto we have taken this tissue as a product, a ready-made veil, behind which lies, more or less hidden, meaning (truth), we are now emphasizing, in the tissue, the generative idea that the text is made, is worked out in a perpetual interweaving" (Pleasure 63).

${ }^{10}$ In The Political Unconscious: Narrative as a Socially Symbolic Act, for example, Fredric Jameson makes the case for a dual tex tual and contextual analysis conducted in specifically political terms. The précis to this text notes that Jameson "opposes the view that literary creation can take place in isolation from its political context. He asserts the priority of the political interpretation of literary texts, claiming it to be at the centre of all reading and understanding, not just a supplement or auxiliary to other methods current today" (n. pag.) .
} 
study, then, will examine the complexly interwoven relationships of the material reality of South Africa, the various discourses that tell stories about that reality, Coetzee's narrative strategies, and his primary thematic concerns. (22).

Gallagher's analytical strategy offers a model for my own. We have each chosen to interact with an oeuvre "that arises out of history, but also rivals history" (Gallagher abstract) - this is Coetzee's understanding of the novel's relationship to history in which, "in times of intense ideological pressure $[\ldots]$ the novel $[\ldots]$ has only two options: supplementarity or rivalry. It cannot be both autonomous and supplementary" (J. M. Coetzee "Novel Today" 3). The central concern is to analyse the various means by which this interaction occurs. Gallagher demonstrates that Coetzee's works operate as a series of responses to discursive practices in South Africa. His novels "suggest a more accurate human history would encompass more than just the material world and the will to power; it would include outcast voices and the ineffable transcendent" (Gallagher xi-x). I will attempt, as Gallagher has done with Coetzee's work, to place Brink's fictional oeuvre in chronological, geographical and ostensibly 'factual' contexts. This attempt will be made in order to interact with texts not merely as fictions, but also as contextual narratives or, to employ Gallagher's term, "cultural conversation" (Gallagher 13) ${ }^{11}$ in which dissident forces are often in operation. The discussion which follows will address the historical, sociological and literary nexus in operation in Brink's work. Thus, my aim is to explore the extent to which Brink's novels respond, in a rewarding way, to specific historical and social realities. I will endeavour to place Brink's novels as revisionist texts that continually interrogate South Africa's historical narrative(s).

In these terms, the series of analyses which follow should be understood as New Historicist in approach, a method of reading which aims, as Edward Said notes, "to make visible, to give materiality back to, the strands holding the text to society, author, and culture" (Gallagher 15). As literature is created in specific environments, 
inter alia cultural and political, it must also be analysed in these terms in order to gain a fuller appreciation of the resonance of these origins. In Brink's own terms, these readings hinge on the political or ideological context of literary production and consumption, rather than mere aesthetics. He notes that a reading position such as this "regards the artistic text as part of an intricate sociocultural discourse, a network of interrelations which is simultaneously the product and the cause of the text" (Reinventions 15). His texts are rooted firmly in a specific socio-historical web which both informs and is informed by the texts. Therefore, a continual awareness of the interplay between author, environment and audience or, more succinctly, between text and world, is of primary concern. Equally crucial is the role of transtextuality, in which echoes of previous textual interpretations of the world continue to flavour new ones.

In essence, this series of readings of texts, and the analytical approaches which correspond to them, all gesture towards the importance of narrative as a means of identification and understanding. Brink, like other writers and philosophers before him, understands narrative to be the means by which senses of identity and belonging may be obtained. In Narrative and Self, Anthony Paul Kerby claims narrative as the "primary embodiment of our understanding of the world, of our experience, and ultimately of ourselves" (14 qtd. in Worthington 13-14). Brink's conception of the purpose and strength of narrative is framed in similar terms; he notes, "[i]nventing stories can offer us a possibility of understanding a little bit more about the world, going back to the basics (Brooks 3). Under these circumstances, he claims that, "Rather than becoming obsolete, the function of the storyteller is becoming more indispensable" (Brooks 3). These interrelated claims form the basis of my focus on the text, its narrative themes, technical forms, context, intertext, subtext and pretext and direct my interrogation of the role of both the artist and artistic creation.

\section{The Value of Dissidence}

\footnotetext{
"Gallagher's term is later reflected in Brink's reference to "the processes of cultural communication" (Reinventions 10). in which writers engage; I believe Gallagher's term captures the interactive and
} 
Having now established the nature of Brink's contestational stance, I wish to briefly raise some issues in respect to dissidence itself, which will frame my investigation of Brink's work. As I have intimated above, Brink clearly revolts against what he considers an oppressive and unjust milieu. His conception of the state and its prejudicial tenets motivates him to challenge these aspects of his environment. As I will demonstrate in the following chapters, Brink's oeuvre is driven by various mandates, each of which impels the reader or individual to contest that which s/he considers unjust. However, one must ask whether dissent is necessary or of value and, if so, in what context? Certainly, a challenge to oppressive and unjust environments has value in articulating alternatives to an authoritarian regime, but who defines oppression or injustice? Where the freedom to choose is curtailed by political or other ulterior motives, the dissenting voice traditionally critiques, while simultaneously offering alternatives. However, by definition, the subversive role requires something to be subversive against: there is a co-defining binary relationship between discourse and counter-discourse. This co-definition frames the manner in which any challenge is launched. Brink, for example, attacks institutionalised, prescriptive religion - initially on the basis of a renegotiation of his own identity as an Afrikaner and later, as a myth by which the Afrikaner spuriously claims superiority in the apartheid state. One must ask, if he positions himself as anti-religious, then why does he choose to engage with religion? It is my contention that there are dual, interrelated reasons. First, his challenge is framed by his own identity as an Afrikaner: he is unable to distance himself entirely from that which has shaped his identity and sense of belonging as an Afrikaner - a Calvinist upbringing. As I will argue in relation to The Ambassador, Brink's textual examination of religion represents a process of negotiation in which he attempts to redefine his position in various communities, one of which is in the context of religion. Second, and particularly in texts from Looking on Darkness onwards, Brink makes a choice, deciding to directly engage with - rather than ignore - that which he considers unjust:

ongoing nature of the process more fully. 
his work is permeated with religious references in order to undermine the specific constructed and prejudicial structures of apartheid.

The mutually co-defining nature of the relationship between the 'oppressor' and the dissident is of particular interest in respect to Brink's work. Brink argues that, in an "ideal situation the writer (and the artist generally) prevents stagnation by defining new options; he is the agent of change, of exploration, of risk" ("Censorship and the Author" 16). He suggests that, ideally, state and artist each act to balance the excesses of the other: "Neither can really do without the other. The artist on his own would introduce anarchy; the agents of society, if left unchecked, would impose absolutism' ("Censorship and the Author" 16). However, in a less than ideal situation, the equalising effect is unbalanced as one of the elements takes control. In apartheid South Africa, the state usurps the authority of artists and thus represents totalitarianism. In this context, the state determines the 'taboo' - the censored - that which is disallowed as thematic material for artists. The mutual bond between discourse and counter-discourse arguably creates a crisis when authority is destroyed or disbands: the post-authoritarian crisis is one in which the subversive role must be redefined in opposition to a new authority. Where a new authority has not yet been established, the dissenting voice arguably becomes mute - until, that is, the emergence of a new discourse. Thus, dissident roles are constantly under negotiation, whether in relation to (oppressive) authority, or in response to its loss.

I have argued that dissidents may be muted by the overthrow of an established authority. However, it must be acknowledged that dissenting voices assert their own authority, and that this may stand as an alternative to the usurped model. In this respect, dissident stances are problematic in that they ostensibly challenge the prescriptive model in operation, and yet essentially offer an - arguably equally prescriptive - alternative. My comments above suggest that dissidents will continue to inhabit positions from which they will challenge whatever new (prescriptive) authority is established. There is, however, the danger that dissidents will instead usurp the authority of the oppressor and merely replace one form of oppression with 
another. Ideally, dissenting voices must remain marginalised, ex-centric and oppositional to an oppressive regime: there is no justifiable position of dissent in opposition to a fair and equitable system of governance. Again, the oppositional and co-defining nature of discourse and counter-discourse is crucial.

The value of the counter-discursive stance is thus predicated on the nature and extent of the discursive. In apartheid South Africa, the insurrection against an overtly prejudicial and oppressive regime is favoured - by those who value fairness and equity - because the injustices of the apartheid era are severe and overt. Arguably, in social systems where the policies and behaviour of the authorities are less intrusive, less violent or overt, the position of dissenters is granted a lesser value. In terms of literature, therefore, dissenting artists are judged by the manner in which their works respond to the rhetoric of authority. In this respect, dissenting voices are always responses to the actions and statements of a higher authority, unwelcome replies to the monologue of the establishment.

Speaking of his distaste for purely politically dissenting literature, Milan Kundera claims, "The nonconformity of the novel [...] does not lie in its identification with a radical, opposition political line, but in presenting a different, independent, unique view of the world" (154). Brink's subversive tactics are launched against a range of fixed and foreclosed aspects of his environment, offering instead the possibility of alternatives. In response to the official, sanctioned record of history, he offers narratives of black, coloured or female South Africans - those traditionally silenced or ignored by (white/colonial) historians. In doing so, he demonstrates his understanding of the ideological assumptions inherent in traditional official and singular modes of historical record, a recognition particularly apt when considered in relation to apartheid South Africa. J. M. Coetzee shares this awareness, stating that "history is not reality; that history is a kind of discourse; [...] that, inevitably, in our culture, history will, with varying degrees of forcefulness, try to claim primacy, claim to be a master-form of discourse" ("Novel Today" 4). The implicit danger recognised here is that master narratives may be, and often are, 
espoused as truth, becoming self-fulfilling methods of control in which contradictory or alternative modes of belief are forcibly disallowed or devalued as 'untrue'.

Crucially, dissidence is defined as a breaking away from authority, a questioning of the status quo; is this, however, a truly dissident stance? Problematically, this type of opposition is not in itself questioned or undermined, but is generally assumed to be an inherently noble and moral position. In respect to dissidence as a concept, and to Brink's work specifically, several questions must be addressed in order to evaluate the oeuvre and the implications of its politically dissident stance. On what basis, for example, is contestation judged noble and/or moral? The apparent 'purity' attached to the motives and behaviours of dissidents must be critiqued in much the same way as that of the state/oppressor. Dissidents are as ideologically moulded as any other individual, and inevitably constrained by these factors; therefore, they cannot pretend any moral purity in these terms. Further, dissidents are mutually defined by an adversary of some kind, a (conventionally dominant) individual or collective deemed oppressive, unjust, or wrong. Clearly, this binary understanding is too simplistic to describe the intricacies of social or political morality; both dissidents and their adversaries are neither purely 'good', nor 'evil', but a mixture of the two. And finally, one must consider the situation of dissidents who no longer have a suitable adversary - in a post-apartheid context, this hypothetical context is particularly apt - do dissidents become redundant, or is there inevitably a new cause with which to align in any particular environment? In each of the situations identified above, I have intimated that dissident positions are not inherently favourable, and that they must instead be judged by some evaluative model.

If dissident stances do not automatically confer moral impunity, then on what basis may one judge the literature of a dissenting artist such as Brink? This is a concern raised by the artist himself in various ways over the course of the oeuvre; throughout, the author focuses on the role and effect of art as a subversive political tool. There is a question implicit in each of the texts: how effective is a (dissident) 
artist and her/his medium? I contend that, although dissident positions are not inherently of value, there are certain criteria by which dissenting voices may be evaluated. It is not the position of contestation itself which is the focus of my evaluation - although that is significant in the particular context of South Africa - but rather the purpose and effect of that dissent. In examining Brink's novels and interrogating the role of the artist in a political context, I will demonstrate that Brink's oeuvre is an effective contestational tool against a restrictive and censorial regime. Further, I wish to trace a development in the work, and discuss the manner in which Brink's contestational stance is transformed in direct response to various social, political and literary conditions. Most importantly, perhaps, my examination will demonstrate that Brink's texts interrogate both the apartheid state (and its postapartheid counterpart), and also themselves. In this respect, they do not pretend moral impunity, but arguably undermine all authority, including their own (dissenting) stance. While Brink's novels may fail in various ways, the self-interrogation foregrounded in each suggests a willingness to continually reassess and reconfigure, an ongoing process of interrogation which I consider the hallmark of truly dissident literature.

This understanding of Brink's literature as a process of interrogation has prompted me to consider the texts not solely as individual entities, but also as a(n incomplete) project. I have chosen to discuss the novels primarily in groups, in order to demonstrate Brink's range of approaches and reactions to certain topics and contexts. This thematic approach cannot encompass all of the issues central to the South African environment, or indeed to Brink's work, but rather identifies pivotal, recurrent concerns in the works and traces their development. I wish to establish a developing political and social consciousness over the course of the oeuvre, and also to demonstrate the author's willingness to return to central themes and interrogate previous understandings. This discussion first establishes Brink's ongoing commitment to resist authoritarianism, traces the ways this is rehearsed in his oeuvre and then addresses questions concerning the dissident author's changing role once an 
oppressive authority is defunct. It examines the evolving contours of Brink's specifically dissident cultural conversation and the implications of that dialogue. 
CHAPTER 1

\section{The Origins of Political Dissent in}

The Ambassador

"our gay little pilgrimage of wonder and discovery"

(Brink Ambassador 276). 
Brink's various re-births represent a series of philosophical, personal and ideological epiphanies which inform his literary oeuvre. As I intimated in the introduction, the first of these re-births symbolised an awakening from the ideological constraints of the Afrikaner community; in essence, Brink became rebellious against the beliefs of his own people. The epiphanic moment when Brink sat on a park bench in Paris represents the beginning of an ongoing spiritual, emotional and intellectual journey. Throughout his literary career, there is textual evidence to suggest Brink's continual reassessment of his own position and that of his society. From the initial inklings of protest against the ideological environment in which he had spent the first two decades of his life, to the more mature investigations of the origins and contexts of such a heritage, to the most recent engagements with a nation attempting to deal with its horrific past, Brink's literature traces both his own growth and that of his homeland. The initial stirrings of this interrogation are evident in the first of his novels published in English, The Ambassador $(1967)^{12}$. A range of themes are introduced in this early novel, each of which is further examined and developed in later texts. It is for this reason that it has been chosen as the first text under discussion, in order to provide an originating point by which later developments in the oeuvre and in Brink's politics may be measured.

As in all Brink's works, a dualistic textual and contextual approach is central to an appreciation of this early novel and to the resonant role it has in his oeuvre as a whole. The opening paragraphs of the Author's Note to The Ambassador ${ }^{13}$ clearly demonstrate this relevance. Speaking of the years he spent in Paris, Brink

\footnotetext{
${ }^{12}$ Earlier Brink texts were published solely in Afrikaans. The plays include Die band om ons harte (1956), Caesar (1961), Elders mooi weer en warm (1965) and Bagasie: Triptiek vir die toneel (1965). Novels include Die meul teen die hang (1958), Die gebondenes (1958), Eindelose weë (1960), Lobola vir die lewe (Pledge for Life) (1962), Orgie (1965) and Miskien nooit (1967). Travel books include Pot-pourri-sketse uit Parijs (1962), Sempre Diritto - Italiaanse reisjoernaal (1963), Olé-Reisboek oor Spanje (1965), Midi: op reis deur Suid-Frankryk (1969), Parys Parys: retoer (1969) and Fado: ' $n$ reis deur Noord-Portugal (1970).

${ }^{13}$ Unless otherwise stated, all references are made to the revised English text of The Ambassador. The novel was first published in Afrikaans as Die Ambassador in 1963 and was translated by Brink into English as The Ambassador in South Africa (1964) and as File on a Diplomat in Britain (1967). Brink described this early translation as "embarrassingly deficient" (9) and in 1985 published a new edition, "an entirely new translation which is also the result of extensive revision of the text itself" (10). This
} 
acknowledges the influence this period had on his beliefs, on his own work, and on that of the Sestigers. He claims the Parisian experience represented a release from the strictures of his South African environment, and an opportunity to explore alternatives. However, Brink describes this 'freedom' as a traumatic experience: "[a]fter more than twenty years within the comfortable, closed framework of conventional Afrikaner attitudes, values and beliefs, the sudden discovery of all the cross-currents of thought and experience in Europe was a cultural shock from which it took years to recover" (Ambassador 9). Brink's protagonist undergoes a similar cultural crisis, mirroring the position of one newly aware of the incongruities of his privileged social role. In terms of both plot and theme, the text is an exploration of environment and context: "[f]or me", Brink claims, "The Ambassador was the first expression of a search and an exploration which is still continuing" (Ambassador 9). Brink's protagonist enacts this metaphysical enquiry on Brink's behalf, questioning the very bases on which his life has been founded. The seemingly privileged and protective environment of the Embassy becomes stifling as he undergoes a crisis of faith in religion, morality and politics.

In undermining the 'security' and 'comfort' of exclusivity, Brink juxtaposes the South African Embassy and its recluses against the seething life stream of Paris. The Ambassador's wife, Erika, notes of the Embassy and its inhabitants that "we are [...] shut in by our four walls, protected from this strange spectacle, life, of which we've heard, but which we hardy know at all" (52). Cultural and moral rigidity are exemplified in the enclave of the Embassy, in its sterile architecture and fittings, in the Ambassador's office which is likened to a "prison" (100) and, most specifically, in the Embassy employees. Anna Smith, for example, epitomises the cultural rigidity and fixity of belief of the Afrikaner establishment. Stephen notes, "her ideas tend to move in an extremely narrow circle. (Move? They stand very firmly, in the tradition of Luther). She has 'unseverable bonds' with her People, her Language, and her Church - Dutch Reformed" (44). Thus, she exemplifies the traditionally stereotyped

chapter focuses primarily on the superior revised edition, but makes reference to the earlier translation, as appropriate. Essentially, I discuss the two texts as variations of the same narrative. 
Afrikaner, staunchly secure in moral, cultural and religious superiority. Refuting all other modes of belief, she describes Paris as "such a terribly profane city, so Catholic" (176), ironically remaining oblivious to the ritualistic nature of Catholicism and the manner in which it mirrors the many rituals associated with Afrikanerdom.

In contrast to the sterility of the Embassy, the city is a bohemian, exotic and chaotic environment. It also represents a co-habitation of extremes: in the centre is Notre Dame, a place of conventionality and ritual mirrored by numerous other cathedrals, and constantly juxtaposed with brothels and nightclubs. Central to this contrast of apparent purity and sinfulness is Nicolette's residence, a microcosm of the city itself. The promise of both good and evil is embodied in the engraved images on her front door. The "weather-beaten scenes from a pagan paradise" (164) are a melting pot of mythological and religious imagery of "a long-lost paradise" (109), and reflect the tarnished Venus within. Likewise, the city represents a mixture of elements, each of which feeds on others: the duality of binary oppositions such as good and evil are revealed as too simplistic to describe the fullness of the city and its people. Further, an environment in which both the authoritative and the 'dissident' co-exist undermines prescription and prohibition. In a street-scene described by Stephen, this co-existence is represented:

[1]eaned back against the dirty wall she [a prostitute] just stared at me through drooping eyelids, no expression whatsoever on her face. Above her red head, in high, uneven letters a fanatic had written: Love thy neighbour as thys- The rest was a whitish, dirty smudge. Underneath was an obscene drawing and the word merde. And behind her forbidding black letters proclaimed: Défense d'afficher. Loi du 29 juillet 1881. Three yards away, on the edge of the pavement, was a round disk attached to a pole, with the inscription, Défense de stationner. (19)

This image acts as a visual metaphor for confrontation with authority. The prostitute, the obscene drawing and the profanity refute the authority of religion and state. The cultural conversation begun in this text is premised on undermining both state and 
church, two central symbols of prescriptive and prohibitive authority and the two which, for Afrikaners, are at the heart of the conception of civil society.

\section{The Exile's Search for Meaning}

"forever on the verge, outside it all, unable to understand"

(Brink Ambassador 158-159).

The various searches for meaning undertaken by the text's central characters are each initiated by feelings of exclusion, a metaphorically exilic experience. Nicolette's search is tied to religion and to her ostensible exile from the Catholic faith. In the (imagined and mimicked) rituals of confession, absolution and worship Nicolette performs she derives some comfort, and yet she is ultimately denied the certainty of religious faith, through self-imposed exile. She considers herself unworthy to be admitted to the Catholic faith because she remains unbaptised; she laments, "[i]f you're not baptized you have only your natural human life. This body [....] But if you're baptized you have a supernatural, immortal life as well. Don't you think that's important? Unbaptized, you live without grace" (179). Despite her Afrikaner identity, in the text Nicolette also epitomises the excluded, the other who is denied admittance to the exclusive community of those who have deemed themselves superior. ${ }^{14}$ In religious terms, Nicolette represents black South Africans, those excluded from the privileges of the white world. Such inversion of black and white identity undermines this binary pairing and encourages examination of the prejudicial foundation of such terms. In this sense, Nicolette's variable positioning in the text, ranging from the exclusive to the excluded, blurs such boundaries, exposing the manner in which they are constructed.

\footnotetext{
${ }^{14}$ It must be noted that the other is a mutable term, referring only to that which is not self, rather than to any fixed individual or group, or exclusively to those oppressed. Thus, a male Afrikaner identified with the hegemonically empowered of South Africa may equally be considered other in relation to selves who do not identify with these categories. Throughout this work, the focus on the other is almost exclusively related to those who have experienced oppression in apartheid South Africa; namely, black, Coloured and/or female South Africans. The aim is not to collapse these different oppressed groups into one discourse of oppression, but rather to reflect on the manner in which the justifications for each form of oppression are undermined in Brink's oeuvre.
} 
Defining Nicolette as an exile is, however, complicated by her own complicity in that exile. If she truly wished to become a member of the exclusive religious set, then she would become baptised and be initiated into that group. Unlike the black South Africans with whom I compared Nicolette, she has a choice. Due to the colour of her skin, she could belong, if she wished. However, her way of life - her sexual freedom and mode of employment - are significant factors in her sense of exclusion from religious grace. In these terms, her 'exile' is a decisive act of self-exile. Clearly, there is a tension between her desire to belong and her resistance to categorisation, conformity and constraint, a conflict which is arguably rehearsed in all exilic positions.

Nicolette's simultaneous desire for, and fear of, religious acceptance symbolises the cultural schizophrenia of the exile, a theme which recurs in both South African politics and literature and in Brink's own oeuvre. I have intimated that Nicolette is both drawn to, and wary of, the church and its icons: "round her neck she wears her worn-out old brown rosary like a piece of valuable jewellery" (218), and yet the Ambassador notes that "[i]n spite of the mystical attraction the Church has for her I often notice, whenever we pass a priest or a nun in the street, that her right hand forms the fica sign against the Evil Eye" (274-275). Her superstitions denote a fear concomitant with the desire she feels to belong to this exclusive set. The exilic experience is envisaged here as both isolating and liberating. In these terms, it may be seen as the result of either a rejection of the individual by a hegemonic community or as representative of a conscious decision on the part of the individual to operate outside of the constraints of a delimiting milieu. Thus, exile represents not merely a tool of exclusion (on the part of a group), but also a choice which may be made by the individual in a deliberate movement away from a prescriptive society. ${ }^{15}$ In the latter, a deliberate, conscious choice to become exiled is a threat to authority in its refusal of hegemony and in its adoption of an alternative mode of living - though at the same 
time a kind of capitulation, given that the removal 'works' by removing oneself from the reach of the society in question and thus, concomitantly, one's absence removes one's dissension as a direct and problematic intervention in the social fabric. Whether the exile has chosen that condition or not, s/he is potentially vulnerable to the effects of cultural schizophrenia, in which the desire to belong co-exists with a fear that individual identity will be subsumed in the hegemony of the group.

Nicolette's exile exemplifies the manner in which circumscribed notions of identity and therefore of belonging, exclude the other, an exilic experience which is further emphasised by Edenic imagery, in which access to Eden is denied. She tells the Ambassador of an incident in which she was "chased out" of the Luxembourg Gardens at closing time (194). Nicolette's story of being locked in at the forest of Versailles at night and having to climb over the grille to escape complicates this image of exclusion. She wonders, "[w]hy does it happen like that? Why do I want to get in when I'm outside; and if I'm locked in I get scared? Why can I never find rest?" (194-5). Parisian gardens envisaged as paradisal or Edenic places recur throughout the text. ${ }^{16}$ Initially viewed as desirable, ultimately, the very conditions by which these gardens are judged induce feelings of suffocation, stifling the inhabitants and resulting in the rejection of such confining environments. Thus, when Nicolette's various attempts to enter the paradisal garden converge in her narrative of escape, the security of the garden with its gates and locks is revealed as a place of imprisonment. This implicit questioning of the confinement and exclusionary tactics of such environments speaks not merely to a religious context, but delves deeper into the hegemonic foundations of many exclusionary and/or authoritarian groups. Themes of exile, as exemplified in this text, recur in South African literature as a means by which to explore the exclusionary nature of regimes such as apartheid. In Brink's later novels, his awakening to the delimiting consequences of such apparently privileged communities, and of the narratives about them, is far more explicitly

15 The manner in which this choice represents a specifically dissenting position is important in later discussion surrounding the decision to challenge the state, and to debate as to how this challenge may be made. 
voiced, resulting in a critique, specifically, of the Afrikaner hegemony of Brink's own upbringing. Thus, thematic concerns with exclusion and exile in the text demarcate Brink's initial engagement with issues which later lead him to critique both Afrikaner hegemony and the apartheid regime which derived from it.

The isolation, solitude and loneliness of the exile searching for community may be likened to the experience of the existentialist subject who has no guiding force with which to identify. The exilic experience is frightening because it defies categorisation, representing a space beyond the security and comfort of the known. The solitude experienced by each of the central characters $(140,163)$ and recurrent throughout the text in images of isolation (141) acts as a reminder of this void. Erika, in particular, notes the manner in which Ambassadorship and the Embassy represent exile from the South African homeland, and yet also acknowledges that South Africa itself no longer seems like home. Exiles may not identify either with an old homeland or a new one, and may instead experience feelings of 'in-betweenness'; they are faced with the prospect of the continual restlessness Erika describes as "drifting" (58). Physical distance from one's homeland is not a pre-requisite for feelings of exclusion, or metaphorical exile, however. South Africans who are deemed beyond the confines of exclusive communities, whether through their own actions, or due to the colour of their skins, may also experience exile within South Africa. This was the experience of millions of black South Africans who, under apartheid legislation, were essentially defined as 'non-citizens', despite being granted their own 'homelands'. White South Africans who refused to comply, or to remain silent, in a prejudicial regime, were similarly excluded from the white enclave.

The exilic experience prompts a search for meaning, identification and belonging: this search is, however, problematic in its own way. Nicolette's (complicated) desire for religious acceptance is, arguably, symbolic of a generic desire for belonging and a search for meaning undertaken by each of the central

\footnotetext{
${ }^{16}$ Notably, the Luxembourg Gardens were the site of Brink's proclaimed epiphany when he began to question the ideological basis of his Afrikaner roots.
} 
characters, the author himself, by means of his text, and ultimately by the reader also. While at Mass, the Ambassador suggests Nicolette "is trying to reach out from herself, beyond the balustrade separating us from the faithful, beyond all barriers, to a wider expanse, a purer form of existence, salvation; and I can feel my own urge growing with hers, because I know it will give meaning to so much of the confusion I live in at the moment" (220). Their search is "for common denominators, symbols to render life intelligible" (221). Eventually the Ambassador realises that Nicolette is not interested in God, but rather in the ritual of belonging, a ritual mirrored, in various ways, by each of the novel's central characters. Having no identity except through others, Nicolette exemplifies this notion. Whether in a ritualised union such as marriage, in sexual coupling, national commonality or in a notion of shared superiority such as that which underpins Afrikaner belief, these characters strive for identification with others. Collective identity, it appears, is the only means by which the individual has meaning in an existential world: identity is realised only in its reflection by others, by commonality, shared experience, origins and beliefs or, in the act of sexual union, in shared physicality. Thus, the ritualisation of these communal bonds becomes the framework against which identity leans.

Paradoxically, the very act that could offer communion also involves a fear of loss of selfhood, or selfhood undermined. Offering a means by which to articulate shared values, beliefs and experiences, celebrations such as those related to national and religious holidays and events operate as markers of belonging (and, consequently, of exile). These customs - the rhythms and patterns of a society - are designed to give some form, in existentialist terms, to an otherwise meaningless existence. Much as the Latinate liturgies of the Church and the festivals of the religious calendar correlate the lives of the faithful to that of their higher being, celebrations such as New Year's Eve give celebrants a sense of purpose beyond their individual existences. The Ambassador, however, notes that the celebration of New Year's Eve "is merely a civilized mask for the ancient, primitive fear of the unknown, and, perhaps, of death" and notes "the deceit inherent in any custom, any 'system"” (188). The ritual of baptism is of particular significance in this text; the baptised may remain 
confident in their place in religious festivities, in the Church, and ultimately in the afterlife; however, those who, like Nicolette, remain unbaptised and without Grace, are exiled from these privileges. "Sed libera nos a malo"17 (221) resonates throughout the text, representing a request for deliverance from individual freedom, a plea for communality. The Ambassador asks, "is this what [Nicolette] has come for, to form part of this rhythm and illusion of certainty, this unchanging pattern?" (220), and concludes, "[a]ll she wants to escape from is the fear that liberty may include evil; and that she may destroy herself by remaining free. And so she takes refuge here, in this beautiful pattern" (221). Images of pilgrimages, both literal and figurative, religious and secular, permeate the text in a physical exemplification of characters' searches for meaning, identity and origin. Likewise, the reader is invited to experience the search for meaning, forced into a voyeuristic position and encouraged to untangle the nightmarish images experienced by the Ambassador as he remembers his childhood discovery of adult sex (72-73). This keyhole image recurs throughout the text in various forms in resonation with the reader's implicit role in creating meaning from the text.

The persistence of religious reference and imagery in the text suggests religion is a central concern for Brink at this time. Rather than dismissing religion entirely, he examines its role in his society and reveals both positive and negative attributes. The tension between negative and positive representations, and of religious acceptance and exclusion, indicates a process of authorial investigation. Brink appears drawn - like Nicolette - to the comfort of religious belonging, while simultaneously rebelling against the church's exercise of authority - like Stephen. Here lies early indication of Brink's later movement towards a direct critique of the Calvinist religion and its Biblical myth of white superiority, a fundamental justification of apartheid ideology - both the curse on the offspring of Canaan and the confusion of Babel are refuted. In The Ambassador, Brink attempts to renegotiate the relationship between the individual and religion, instigating a search for identification, belonging and meaning which permeates his oeuvre.

${ }^{17}$ ('Deliver us from Evil'). 
In their dreams Nicolette and the Ambassador both metaphorically envisage the manner in which their lives are meaningless. The Ambassador's description of his life as a "journey through the land of Nod" (162) highlights the existential tone of the text, in which life is of a dreamlike substance, without form or purpose, an endless wandering, desperately searching for a meaning which is ultimately denied. Nicolette's childhood sleepwalking, in which she is lost, confused and directionless, signals an anxiety: the fear that life might be meaningless (248). Meaninglessness is central to existentialist philosophy which understands there to be no outside purpose, authority or guidance; an understanding of particular interest as contrasted with the conventional religious adherence of Afrikanerdom and the authoritarianism of apartheid. Thus, Nicolette's fascination with astrological readings illustrates her (irreligious or secular) desire for meaning, purpose and explanation, which is unattainable to the existentialist subject $(15,265)$. Characters in search of individual or collective meaning undergo a quest for identification, striving to belong. Brink's own quest is mirrored in those of his characters: in each of his texts, and over the course of his oeuvre, he also undertakes an exploratory journey endeavouring to discover his identity as an Afrikaner, his place as a (dissident) writer, and as a South African.

One means of confronting meaninglessness is to create meaning through narrative, as Brink does, and many of his characters do, in his texts. This is perhaps the central concern in Brink's oeuvre. The proliferation of songs and prayers in The Ambassador $(114,148,180)$, and the recurrence of the Au clair de lune song in which entry is forbidden (116-117, 142-143, 220-221, 248, 287), exemplify the characters' attempts to gain meaning through narrative. Nicolette's recital of something which could be either a religious liturgy or a rhyme from Mother Goose (180) undermines the conventional distinctions between 'high' and 'low' art, placing them on equal footing (at least at the level of function), and, in the context of the novel's thematic concerns, lays both bare as narratives invoked to keep meaninglessness at bay. The Ambassador enacts 'authorial' roles at various levels of narration: he acts as one of 
the text's narrators, in the past he was a fiction writer and in his current employment is responsible for providing a myriad of reports and statements. In each of these ways he is a creator of narrative, a role which is described in existentialist terms: "[e]ach word that took shape in black letters on the white paper under his hand was a small creative act against meaninglessness. [...] What he did was done because he could not conceive of any other form of existence, because that had become his only way of expression, of finding meaning." (83-84). The Ambassador enacts his author-ity upon the blank page, inscribing meaning onto meaninglessness, and thus the proliferation of paperwork, reportage and note taking permeating the text acts as a recurrent metaphor for such attempts to impose meaning. In an authoritarian environment, in which identity is circumscribed or enforced, this undertaking is of particular importance as an act of contestation against the imposition of individual and collective identities, and therefore of meaning. The challenge to the imposition of limited and fixed meaning is a crucial stage in the re-negotiation of author-ity.

This re-negotiation also demonstrates a series of attempts to gain meaning. Nicolette, for example, explains the hardships of her life in terms of a nursery rhyme, stating, "I was born on a Wednesday, you know [....] Wednesday's child is full of woe" (113). She is also imaged in a series of word portraits, or mini-narratives framed as chapters: "[t]he endearing way she has, whenever she feels upset or sad, of twirling a little curl on her forehead with one finger, faster and faster, until she is soothed or falls asleep" (218). In the context of the existentialist vein of the text and the themes of alienation and exclusion which permeate it, the overall effect is to deny the possibility of knowing another in any meaningful way. The Ambassador acknowledges the correlative failure of art to mirror reality when Nicolette has her portrait done and he comments, "[i]t was not a bad resemblance after all, although it certainly wasn't Nicolette - but how could anybody capture her on paper?" (31). This notion is substantiated in mirror imagery which explores the self as reflected through a medium, in this case, the mirror. Of particular relevance is the description of a broken mirror in which pieces of Nicolette are visible, but not the whole (242). This dismemberment of identity, metaphorically realised in the separate images of 
Nicolette's body parts, suggests identification is requisite upon some medium by which it may be reflected. The mirror-frame provides cohesion in a situation which is otherwise fragmentary and meaningless: it represents a narrative by which pieces become part of a whole. The shards of broken glass, therefore, speak of the displacement of master narratives, and the resultant existentialist void in which the subject must now search for new forms of meaning. Nicolette embodies the mutability of identities, denying the fixity demanded by authoritarianism. This thematic concern with the denial of identity continues to permeate many of Brink's later texts and colours his own correlative search for (various) identification(s).

Textualisation is also invoked in an attempt to place order on incoherence, or meaninglessness. Stephen's attempts to order experience in his report on the Ambassador's activities are, however, undermined by the disruption of linearity found in the text proper, a device which allows the reader access to a fuller account of the relevant events than is allowed in Stephen's report. The limitations of chronological renditions are exemplified in the Ambassador's description of Nicolette in which he asks, "[h]ow can I give a chronological account of her if she has no chronology? She is a continuous present tense, a book one starts reading in the middle and which has no cover, title page, beginning or end. What I have of her is a jumble of loose impressions" (151). Nicolette represents the limitations of chronological or linear description, the impossibility of capturing identity or reality in a text, and thus metaphorically challenges the fixity of official historical record. Similarly, the manner in which narrated events are constantly revised by subsequent narrators undermines narrative claims to 'truth' (e.g.1985 61 c.f. 99-100; 62 c.f. 103 $105 ; 68-69$ c.f. $121-125 ; 69-70$ c.f. $125-126 ; 63-66$ c.f. $190-192 ; 84$ c.f. 25$)$.

The rebellion against oppressive forms is also undertaken in terms of a rebellion against religion. Throughout the text, the institution of religion is subjected to a series of attacks from various characters disillusioned with the tired formulas of the church. For Erika, the church "has become an equation incapable of solving $\mathrm{x}$ " (197; original emphasis), while the Ambassador's rejection of religious faith is based 
on the formulaic nature of its worship. He suggests, "[p]erhaps it was the linear, hygienic nature of Calvinism that never appealed to me: stark, unimaginative, sober, the miracle of bread and wine reduced to a formula which had long ago lost even its symbolic power" (219). Stephen's relationship with religion is similarly problematic. His upbringing by a strict father whom he both loved and despised has resulted in a rejection of the values of his childhood: for him, religion is merely "the comfort of a convenient fiction" (44)). Gillian's rejection of religion is perhaps the most emphatic. Brought up by a pastor whose "religion had consisted mainly of fire and brimstone, so that as a child her dreams at night had been a never-ending foretaste of hell" (107), her "head-on attack on all conventional values" (107) is most powerfully enacted when she blasphemously tears the pages from her father's Bible (175). Thus, each of these characters represents a confrontation against accepted, conventional values, a questioning of the evaluative and moralistic models of a society - this confrontation clearly mirrors Brink's own (moral) state of siege as a dissident artist.

In demonstrations and questionings of the reliance on institutions (in both senses of the word), the text delineates the origins of Brink's later concerns with institutionalised belief and behaviour, most explicitly critiqued in terms of Afrikaner hegemony and the apartheid regime. Religion bears the brunt of Brink's dissident focus, but is directly correlated to authoritarian regimes per se. The series of minor characters, wandering aimlessly through their transparently futile lives, acting the roles assigned them and desperately avoiding confrontation with anything external to their insulated environment, symbolise the masses subdued by authoritarian or institutional means: these are the apathetic creatures Brink's increasingly dissident texts attempt to awaken. In the text, the Ambassador's rhetoric addresses these issues:

Could it all be reduced to this? - all the organizations people had devised to bolster their security: state and church, commerce and politics and education, everything: the more laws there were, the more refutations, the more securely one's pattern of existence was predetermined, the easier one could continue without the need to think. And all this to maintain an illusion - the illusion 
that there did exist a cosmic, basic pattern of order, that the universe was functioning according to set laws, and that, consequently, society and the individual should also be governed by laws. For this was the only way one could contain the terror of the freedom that lay at the root of all things: this passionate life which existed without aim or pattern or direction, this essential chaos". (169)

This passage articulates the essence of the novel: the author's questioning of the "organisation" imposed on life by humanity, the "conditioned identity" (File 98) of the masses. Crucially, the existentialist refusal of cosmic or universal 'law' and 'order' is linked to a political challenge to the state's order and authority.

The Ambassador, and the title by which he is addressed, symbolise the loss of individual identity in favour of societal roles. Likewise, the social and employment roles of other characters suggest social automaton. Speaking of one of a series of indistinguishable social events at the Embassy, the Ambassador articulates this sense of monotonous uniformity: "[e]very single guest had his or her predestined role to play. Each came equipped with a well-tried set of opinions and convictions: like information punched on a card, so that each time the correct key was applied the same formula was conjured back" (223). Notably, this zombie-like existence is framed in religious terms, suggesting its correlation with blind faith:

I didn't know whether anyone there really believed in it any longer, but nobody would even for a moment consider an alternative; this existence was so well established, so harmonious, so successful. If life had lost its power of transubstantiation, we nevertheless went on drinking the wine, eating the bread, making the required gestures. Come fill the cup. Tomorrow, thank God, we die. Et aprés nous - (223)

Brink's refutation of religious authority, in which the Biblical sanctioning of apartheid resonates, recurs and is developed as a politically dissident metaphor in later texts. In this text, the Ambassador argues that " $[\mathrm{t}]$ he system itself operated and existed only in its absence - like God, $[\ldots]$ in the mind of a good Christian who might commit the most atrocious acts in the pious conviction that it was sanctioned by a 
Being whose existence was, per definition unprovable" (139). In this context, the religious cynicism of the text, expressed by a number of characters, becomes representative of political dissatisfaction and eventual dissidence.

\title{
Sexual Themes
}

\author{
"their shameless affirmation of sexual delight \\ gave me a sort of spiritual concussion"
}

(Ambassador 165).

The inclusion of sexual content and themes in the text, evident in the above description of a soliciting prostitute, is an innovative strategy, in keeping with the objectives of the Sestigers. de Jong notes of Brink's earlier works, "political and sexual subversion are more or less inseparable" (250). In destabilising the carefully construed frameworks in which 'morality' was previously defined, Brink and his fellow Sestigers challenged the very foundations on which the prejudicial and the oppressive depended. Arguably, Brink's focus on Nicolette's sexuality is a refusal to constrain the content of his literature to the circumscribed notions of 'morality' prescribed by the ideals of the church and enforced by the Afrikaner community and, ultimately, by the state. ${ }^{18}$ The sexual content of the text, although tame in contemporary terms, must be discussed in the context of its era and environment. South African literature of the time was largely devoid of sexual reference or profanity, and therefore Brink's inclusion of prostitutes, his depiction of Nicolette's sexual availability, and the (repeated) description of Nicolette's two 'rapes' (37, 41, 238 ; 145) were radical for their time, challenging the boundaries of Afrikaner 'decency'. The sexual content is not merely explicit, or recurring, but often publicly exhibited (228), refuting a conventional and censorial attitude in which such acts are hidden from view.

\footnotetext{
${ }^{18}$ It may also be argued, however, that Brink's sexual depiction of women is an objectification or misappropriation of the male author's role, an argument further explored in chapter ten.
} 
Further, Brink's decision to combine religious imagery and content with that of a sexual nature strengthens this imagery, acting as a reminder that both sex and religion are conventionally 'taboo'. Childhood memories, in which Nicolette reveals her genitals in exchange for apples, operate as Biblical images of lost innocence and sinfulness and the attainment of forbidden knowledge $(238,245)$; simultaneously they depict sexual acts as transactions. The memories also prefigure adult experiences in which religion and sex are linked: during Nicolette's nightclub stripping, for example, she is envisaged "crucifying herself against the light" (192). Descriptions of sexual interactions also employ religious language and ritual such as the terms "praying" and "forgiveness" (240-241) and thus resonate in the text as confessional acts. ${ }^{19}$ In this way, Brink undermines carefully policed boundaries between the 'immorality' of sexual acts and the sacred institutions, language and rituals of the church - sex and religion are granted the same status.

The ostensible sinfulness and immorality of sexual practice is refuted and sex is instead depicted as offering meaning and affirmation. Sexual union thus symbolises metaphysical enquiry, a search for meaning and identity. In response to the overwhelming sense of existential despair experienced by many of his characters, Brink offers union as a possible resolution. Echoing a philosophy originating from Søren Kierkegaard, Brink suggests that individual unhappiness is momentarily forgotten in communion with others. Kierkegaard's notion that "it is impossible to exist without passion" and that "one is able to make sense of one's life as a whole only through personal conduct and relationships with others" (Honderich 259), offers a solution to the angst of the existential individual. The Ambassador's head resting on Nicolette's lap is of greater significance, she claims, than possessions or achievements (147): his meaning is revealed in his connection to others. This philosophy is also crucial to Brink's non-prejudicial directive in which the self must engage with the other in order to become whole: "it is only by entering into engagements whose fate can arouse the passion that we gain a sense of our own

\footnotetext{
19 The text's characters remain entrapped in a triadic cycle of transgression, confession and forgiveness which structures their lives and permeates the very architecture of the novel. Confessional acts and
} 
identity and in that way become an "existing individual" (Honderich 259). Consequently, communion with others is a theme re-addressed and substantially developed throughout Brink's oeuvre.

Brink's notion of self/other union as a panacea to existentialist angst and solitude is, however, fraught with a crucial paradox. Union is contradictory to the binary notion of self versus other: when union is complete, the terms of self and other become obsolete and are transformed to the collective we/us. In this context, the collective subsumes individual identity and the individual experiences a sense of loss similar to that of the original existentialist loss of authority. Whether this collective is an equal sharing, or blend, of aspects of the two individual selves, or, alternatively, an engulfment of one identity by another, is unclear. Herein lies the tension between self and another, and the fear of possession and oppression which frames this text and Brink's others. These questions resonate throughout Brink's work, indicating an unresolved conflict in Brink's 'solution' to the self/other dichotomy.

The sexual act itself is problematic in its representation. Recurring images of prostitution frame sexuality as a commodity and sexual acts as transactions in which financial restitution is not the only form of payment. Nicolette, for example, has received food and lodging in exchange for sexual intercourse (243), offers sexual payment in exchange for the Ambassador's assistance (85) and continues to benefit financially during her relationship with him (273-274). Conventional romantic associations of sex as linked to love are absent or distorted. The portrayal of sexual intercourse is voyeuristic and often animalistic and/or grotesque. The grotesque, for example, is evident in an episode narrated by the Ambassador as he passes through a restroom:

[ $\mathrm{t}$ ]he third door is wide open and in passing I catch a glimpse of a young man and a girl inside standing pressed together, both half naked, pumping away like dogs. On the floor, propped up against a little heap of the clothes they've shed, is a torch, which casts their grotesque shadows against the back wall, 
resembling giants with writhing torsos frantically trying to escape from a well.

Here, the sexual act appears to engulf selfhood, rather than offering identification, as previously claimed. In these terms, sexual acts are as threatening as the solitude and angst of the existentialist individual. Sexual 'freedom', therefore, does not exist, but rather hinges on the same dependencies and loss of individual freedoms which haunt any collective identity. The Ambassador's comment regarding Nicolette's immersion in religion may now be quoted in full. After revealing religion as a place of "refuge" for Nicolette, "in which she may find relief from the evils of solitude, he qualifies his statement by noting that religion's "beautiful pattern [...] will, just as surely, destroy her once she gets enmeshed in it" (221). Thus, Nicolette's predicament exemplifies the paradox of communion, reflecting on the mutual desire for acknowledgement in another, concomitant with the fear of loss of selfhood, or selfhood undermined. This paradox is reflective of all encounters or engagements with the other, in both sexual and colonial terms and thus resonates in the text as a thematic concern particularly relevant in the (post-)colonial context of South Africa.

\section{Politics}

“In Brink's earlier writing political and sexual subversion are more or less inseparable" (de Jong 250).

In political terms, The Ambassador contains few, oblique comments concerning South African politics of the time. At this historical moment, Brink seems unprepared to openly challenge the prejudicial policies of his nation, or of his people. The political environment in which the novel is set is subservient to the exploration of human relationships, providing merely a backdrop to the interactions of the characters. This background, however, provides a continuous undertone of political awareness and tension. Rumours of unrest in South Africa, in conjunction with the misconduct of the two diplomats, threaten to unsettle precarious arms 
negotiations with the French government. South Africa is described as a nation on the verge of violent and cataclysmic change: industrial action followed by police and military retaliation and international concern over such incidents frame the novel (60). In Brink's few depictions of the political climate of the era, therefore, there are cues which gesture towards the need for the overtly political stance Brink was to adopt in his next novel.

Brink's focus on the religious and the sexual is a focus on 'morality' as a concept prescribed by an authoritarian body such as the apartheid government. His objective is a call, to those who have been subsumed by such authoritarian bodies, to seek knowledge beyond prescribed and restrictive realms. Authoritarian states, he implies, construct and police the boundaries of morality which affect all aspects of human interaction. In recurrent religious imagery, he suggests that individuals must choose "between happiness without knowledge, and agony with knowledge" (221): unquestioning ignorance and inertia in an authoritarian environment is juxtaposed against the existentialist agony of the individual who has denied all such authority and taken responsibility for her/his own knowledge. Religious images centred around the tree of knowledge and its fruit depict this juxtaposition. Stephen, for example, invokes the religious imagery of his childhood to portray the angst he experiences as an adult:

I come from a past of Sunday nights and I'm still caught under that spell. Nothing will ever set me free. And I want to be free! No I don't. Why not try to be philosophical and conclude that the Tree of Knowledge bears shrivelled fruit; and sometime or other one has to taste it? It brings no revelation either of angels or of devils, and there is no god who nowadays rounds up offenders in the evening breeze. Perhaps this is the greatest letdown of all. Adam and Eve could at least count on punishment, which gave them something against which to measure, as it were, the extent of their achievement. But if there is no punishment because there has never been any sin to start with, one can only feel duped. (20). 
Here, Adam and Eve are suggestive of Afrikaners struggling to derive meaning in a world suddenly devoid of value. Existentialist Afrikaners experience a sense of limbo, uncertain how to act without the proscribed guidelines of the higher authority of the church. Without judgment on all actions, it appears, all actions are insignificant, irrelevant, obsolete. Stephen's rejection of religious faith results in existentialist feelings of disillusionment and loss: he thus epitomises those who have tasted the fruit of the tree of knowledge, and who can never again return to the prior 'ignorance' and security of their religious selves.

In similarly religious terms, the Ambassador describes the search for knowledge, the precursor to a post-religious era. He states,

Adam and Eve had lived in their garden in the supreme happiness of ignorance. But the fruit of knowledge had to be picked. Not to rebel against God, not to obey the Serpent, but simply because they couldn't have done anything else. To be human means to desire knowledge. Without knowledge there can be no sin; without $\sin$, no knowledge. And how can we exist without either? (171)

The Ambassador, it seems, fully comprehends this existentialist dilemma, and ponders "[i]s not the foundation of all religion the maintenance of the illusion that Paradise still exists? Its image remains alive in us because we cannot otherwise bear the idea of wandering eternally in the land of Nod" (221).

In these terms, Nicolette's relationship to religion, and to an accepted definition of 'truth', is relevant. Nicolette epitomises irreligion and antiauthoritarianism, refusing to remain fixed to one narrative or 'truth'. Thus, she undermines the foundations of religious and state 'truth'. Her yearning for religious acceptance and belonging is concomitant with an acknowledgement of the contradictions and failure of religion. She notes, "[t]hey say it wasn't an apple Eve gave Adam, so I wonder what the hell it was, and why they lied to me" (245). She herself constantly lies, about her places of residence $(24,39)$ and of employment, (36$37,39,104)$ her relationship to the Ambassador (162), and events that occurred with 
Stephen (216-217), refuting the fixity of closed narrative. Her lies represent the myriad truths which she may have lived. Stephen describes Nicolette in terms of her mutability, as a "question mark", a riddle to be solved, ultimately viewing her as "incomplete" (37). In searching for the meaning of Nicolette, Stephen discovers that her refusal of fixity refutes any 'knowledge' of her; she epitomises alternatives to fixity. Narrative is envisaged here as a liberating form of expression in which identity, or selfhood, may be (re-)created and by which meaning is obtained. There are no 'lies', in this context, but rather 'fictions' which allow a variety of engagements with the world. ${ }^{20}$ In this sense, Nicolette is a precursor to Brink's own ongoing narrative response to the political foreclosure of narrative possibilities in South Africa. The indefinable nature of this character reflects on the mutability of identity and of narrative in contestation to religious and state fixity. Her inconstancy also reflects on the existential meaninglessness resulting from a refutation of accepted knowledge, a concern Brink develops in later texts.

\section{Conclusion}

"his long journey"

(Brink Ambassador 285).

The re-birth experienced by the Ambassador mirrors that of Brink. The Ambassador, in his union with Nicolette, undergoes a spiritual reawakening, envisaged as a release from the confinement of his upbringing and of his environment. "It seems to me", he states,

the concept of being 'born again' is merely the Christian equivalent of an experience which is fundamental to every human being: an act of renewal, a dying of the self, in order to become aware, anew, of world and self. And in this sense I have been born again through her. Once born, one cannot crawl

\footnotetext{
${ }^{20}$ As I have previously argued, Brink's oeuvre depicts an alternative view of 'truth' and 'lies' to that officially espoused, In Brink's terms, 'lies' are statements and discourses which declare a fixed 'truth', precluding alternatives. In response, Brink develops his own notion of 'Truth' (which I have
} 
back into the womb, however much some may try to do so; once reborn into this new awareness of the world, it is just as impossible to undo or deny it. (202-203)

The author's proclaimed re-birth, and subsequent involvement with the Sestigers, also demarcates his conscious rejection of the past and its restrictions and the genesis of his objective to embrace alternative modes of understanding and operating in his world. His focus is epistemological in its concern with the nature of knowledge, its presuppositions, foundations and construction, and its extent and validity. Thus, the text operates both aesthetically and also contextually in the environment of apartheid South Africa at that time. The Ambassador is evidence, in terms of both content and theme, of Brink's own exploration of the human condition, a theme which recurs in varying forms throughout his oeuvre. In this text, Brink begins to question the reigning authority of church and state in which sex, morality and religion are strictly policed and circumscribed and to take a moralistic stand against such prescription. This implicit undermining of authority is central to his later more overt political engagements, representing a crucial precursor to the remainder of his oeuvre. The Ambassador, Brink claims, represents "a point of departure; without it, I would not have been able to write Looking on Darkness, or An Instant in the Wind, or Rumours of Rain, or A Dry White Season, or A Chain of Voices, or The Wall of the Plague. It was another kind of writer who produced The Ambassador" (10). This shift, and Brink's developing social and political consciousness, will be traced in the chapters which follow. Specifically, I will provide a series of analyses of the texts in order to consider the politics of writing as dissident politics; I will consider the effectiveness and potentially paradoxical nature of writing as a dissident project.

marked with an uppercase ' $T$ '), as a series of alternative versions which challenge the fixity of authoritarian 'truth'. See Dixon, "Shouting against Silence". 


\section{CHAPTER 2}

\section{Brink, Politics and the Censor - the Power of the Word in}

\section{Looking on Darkness}

"removed from the context of its emotive avatars (protection of virtue, protection from temptation; a superego policing the obstreperous national id), censorship is control of communication [....] that in the final analysis is the process by which men reach out and find each other" (Gordimer "Apartheid" 26). 
If Paris in 1960, and Sharpeville represent epiphanic moments for Brink, a further metaphorical "new birth" ("Introduction: A Background" 34) occurred during another of his "emancipating periods in Paris" (Wheatcroft 14) during 1967-8. This revisitation, in which he experienced the 1968 student revolts, re-invigorated and refocused his social commitment, and the literature published after this sojourn clearly reflects a different stance, demonstrative of his self-confessed "rediscovery of South Africa" (Wheatcroft 14). Admitting that Sestig literature was limited in its scope, Brink implies that the manner in which it relied on Westem influences denied it an individual voice with which to speak of the political realities of South Africa. The nation, he suggests, needs to - indeed must - forge a new literature on its own terms, to respond to its own context. Of his earlier work, he notes that it remained focussed predominantly on issues of religion, sex and morality and that he was afraid to overtly question the political foundations of the apartheid regime ("André Brink Talks" 3). However, the student revolts were primarily, Brink claims, a "revolt against obsolete forms" (States 112) and "brought into focus one issue above all others, $[\ldots]$ the relationship of the individual with his society, and his need to assume responsibility within that society" ("Introduction: A Background" 34). Consequently, Brink's return to South Africa in 1969 heralded a new engagement with South Africa. He determined to accept responsibility for his role in the apartheid regime - a sense of responsibility which is linked to his identification with the ruling enclave of the era, the Afrikaners. His intention, he claims, was to "open up a dialogue with my own society" and produce literature that was "politically committed" ("André Brink Talks" 4). From this point onwards, Brink's work becomes increasingly dissident, engaging more overtly with what he considers the political injustices of his nation. 


\title{
The Muzzle ${ }^{21}$ Of Censorship
}

\author{
"Je permet que tu parles, mais j'exige que tu taises" \\ (I allow you to speak, but I order you to stay silent) \\ (Hugo n. pag. qtd. in Beekman 42).
}

In 1968, the apartheid government proclaimed the freedom of speech of its citizens. A publication intended for international distribution and entitled "South Africa and the Rule of Law" claimed,

It is no offence in South Africa to oppose the policy of separate development. It is opposed by the opposition party in the South African parliament itself. [...] No action can be taken under South African legislation against critics of the South African government as long as their opposition is conducted in a constitutional manner. (67 qtd. in Dugard 149)

As Dugard emphasises, this statement avoids mention of the manner in which the majority of South Africa's inhabitants were denied constitutional means of dissent: they and their voices were, in effect, censored. Defining South Africans in similar terms, Christopher Merrett ${ }^{22}$ acknowledges the manner in which "a speechless people" (201) - an entire body of voices - has been silenced throughout South Africa's history in both literal and literary terms. Freedom of speech is proclaimed by the Universal Declaration of Human Rights, ${ }^{23}$ the International Covenant on Civil and Political Rights ${ }^{24}$ and the European Convention on Human Rights ${ }^{25}$ and yet, in

\footnotetext{
${ }^{21}$ The term is borrowed from Margreet De Lange's The Muzzled Muse: Literature and Censorship in South Africa.

${ }^{22}$ Merrett's seminal text, A Culture of Censorship: Secrecy and Intellectual Repression in South Africa, is the most comprehensive overview of South African censorship to date. His broad definition of censorship encompasses the roles of colonisation, segregation and apartheid as 'censorial' tools. He describes government interference with "political and social rights which govern the communication of ideas and information" (2) and equates state violence with censorship: "the censorship of the bullet" (30). He traces the development from these proscriptive environments to the explicit implementation of legislated censorship up until the election of the first democratic government in 1994.

23 Articles 19 and 20, 1948 (Dugard 146). Article 19 states, "Everyone has the right to freedom of opinion and expression; this right includes freedom to hold opinions without interference and to seek, receive and impart information and ideas through any media and regardless of frontiers" (qtd. in Birley 40).

${ }^{24}$ Articles 19 \& 21, 1966 (Dugard 146).

${ }^{25}$ Articles 10 \& 11, 1950 (Dugard 146).
} 
South Africa, the freedom to speak or to publish in a manner considered subversive to the apartheid state was deemed illegal for a period of some decades.

In the South African context, Brink argues that censorship must be contextualised as part of an overall policy of oppression. Censorship, he suggests, operates in the same manner as any other infringement on personal liberties ("Censorship and the Author" 18), as outlined in Merrett's text. When imposed by the state, he suggests that censorship becomes a political activity, part of a web of measures designed to quell dissent" ("Censorship and the Author" 18). It is a tool designed not merely to police what the public views or reads, but also, Brink argues, what the public should think ("Censorship and the Author" 20) and thus enables the maintenance of the political status quo.

Censorship ostensibly disallows freedom of choice. As Gordimer argues, under a censorial regime,

a whole generation of South Africans is growing up with areas of the world of ideas closed to them, and without any insight into the lives and aspirations of their fellow countrymen, black or white as the case may be, living on the other side of that net of legislation through which we may all only peer at each other dumbly. ("Apartheid" 29)

Her comments are particularly apt in a society subjected to an extended period of censorship, as was the case in apartheid South Africa. The isolation of South Africans - both black and white - from any exterior reality and from each other is apparently the intention and the result of censorship. This is the position of the South African reader, to whom Brink's texts are predominately - although not exclusively addressed. I contend that his novels reveal the isolation of South African individuals from their fellow South Africans and, by implication, from a wider universal community. They also offer the opportunity to participate in a dialogue to counter the silence by which censorial South Africa is defined. Thus, Brink's (increasingly dissident) cultural conversation is increasingly moulded by an awareness of censorial constraints. 
As early as 1961, Randolph Vigne stated, "[w]hile English and African writers unendingly examine and analyse the life around them, very little has been done in Afrikaans that admits the real difficulties of our racial situation" (qtd. in Moyana 86). His comment provides a framework by which to judge the importance of Brink's work at this time. Clearly, Brink was not the first to challenge the authoritarian and racially prejudicial regime of South Africa: he was, rather, the first Afrikaner novelist to publish a substantial piece of literature in which his political dissidence was overtly displayed, and to subsequently have that publication banned. ${ }^{26}$ Following the dissident literature of English and Black South Africans, Brink spoke from within the laager, against his own people.

\title{
Looking on Darkness: Art as a Tool of Challenge
}

\author{
"In South Africa one never writes in a void: \\ there is always a reaction, often violent" \\ (Brink "Breytenbach File" 6).
}

In his second English publication, Looking on Darkness (1974), ${ }^{27}$ Brink specifically and directly engages with his restrictive and censorial environment, confronting the political realities of apartheid South Africa. As I have noted, this text marks the point at which censorial impediments and considerations begin to influence his work. It also delineates a clear development in Brink's literary skills, demonstrating a greater range of characterisation and more careful manipulation of

\footnotetext{
${ }^{26}$ Commentary regarding Brink's banning differs: the consensus, however, appears to be that Brink was the first Afrikaans novellist of any note to be banned, a distinction which suggests that lesser Afrikaans writers, and those writing in different genres, had previously been subject to similar censorship. Breytenbach's collection of protest poetry, entitled Skryt. Om 'n Sinkende Skip Blou te Verf (Skryt. Painting a Sinking Ship Blue) (1972), was apparently the first Afrikaans text to be banned under the new censorship dispensation (Weschler 155).; (Galloway 129), while Brink's text was banned under the old dispensation.

${ }^{27}$ A number of texts including novels, travel writing and plays, were also published in Afrikaans during this era and are beyond the scope of this work. Plays entitled Die verhoor and Die rebelle were released in 1970, Kinkels innie kabel in 1971, Die bobaas van die boendoe and Afrikaners is plesierig in 1973 and Pavane in 1974.
} 
plot, structure, language and metaphor. Also evident is a development beyond the self-focussed dissent of the Afrikaner found in The Ambassador to a more specifically cross-cultural dissent exhibited in Brink's focus on his Coloured protagonist. The result is a text superior, in terms of both artistic and political interest, to those which precede it. In contrast to The Ambassador, which critiqued Afrikanerdom but avoided overt political challenge, this later text demonstrates Brink's objective to directly engage with the political injustices of his country.

Unsurprisingly, the disruption of religious certainty, the inclusion of sexual content and the overt political challenges evident in the text instigated negative criticism from both the public and the authorities. Initial reviews of the Afrikaans version of the text, however, praised both the novel and the author's courageous treatment of race relations. ${ }^{28}$ As de Lange notes, the text was originally treated as "a literary event and not as a potentially political one", with reviewers failing to mention the possibility of a ban (47): notably, no Afrikaans text had ever been banned at this point. In fact, the text was ignored by the authorities for almost a year, remaining uncensored until the first edition was sold out and the concerns of "moral watchdogs" demanded attention (Cope 133). ${ }^{29}$ However, in 1974, two crucial events occurred that were to greatly affect both Brink's own literature and that of South Africa as a whole. First, the Afrikaans version of the text, Kennis van Die Aand was published and subsequently banned in $1974,{ }^{30}$ the first Afrikaans novel to be treated in this way. Second, the new censorship act was legislated and was subsequently promulgated in 1975, further extending censorial powers in South Africa. Noting that the text defied many of the 42 subjects deemed undesirable under the current censorship legislation, Cope suggests a link between the challenge Brink posed to the state and its subsequent decisions to amend the censorship laws and to ban Brink's work (Cope

\footnotetext{
${ }^{28}$ See, for example, Ampie Coetzee's review in Rapport (7 October 1973) and E. Lindenburg's in Die Burger (27 November 1973) excerpts of which are translated in Margreet de Lange's The Muzzled Muse: Literature and Censorship in South Africa (46-7).

${ }_{29}^{29}$ Jack Cope's The Adversary Within: Dissident Writers in Afrikaans provides thorough commentary on the novel's reception and subsequent censorship. Likewise, Margreet de Lange's text is informative.

${ }^{30}$ The novel was published by Buren Publishers, a small South African firm known for its support of 'revolutionary' authors and texts (Brink "Summer" n. pag.).
} 
133). Subsequent to the banning of Kennis van Die Aand, the novel was published in English, entitled Looking on Darkness, and was also banned in the same year and again in 1980. These bannings are indicative of the more stringent enforcement of censorship which characterises this era.

Censorship of literature such as Brink's offers proof of its importance as a tool of challenge. Despite a high percentage of illiteracy, the censorial constraints of the apartheid regime suggest that literature is considered a 'threat'. Merrett notes that "The vehemence with which the authorities persecuted writers was seated in the realisation of their power to communicate universal values so dangerous to the authoritarian, conformist state" (200). His statement echoes Havel's claims that the savage response to individuals who speak out against the totalitarian state is explained by their representation of the 'truth' versus the state's 'lies' (Merrett 6). In this context, literature is framed as a political tool in which a search for alternatives is undertaken. Thus, Looking on Darkness may be viewed as a significant contribution to the development of dissident literature in South Africa. Likewise, Brink's role as a politically challenging artist is crucial. Gordimer notes that Looking on Darkness answers Brink's challenge: "[i]f Afrikaans writing is to achieve any true significance within the context of the revolution of Africa [...] it seems to me that it will come from those who are prepared to sling the "No!" of Antigone into the violent face of the System" (Brink "Position" 15, qtd. in Gordimer "English-Language" 112). ${ }^{31}$ Brink's overarching conception of the artist's role in society is that $\mathrm{s} / \mathrm{he}$ "is not a mere cultural appendage; his influence can be immensely vital and formative" ("Breytenbach File" 6). This possible influence, he suggests, is twofold. The artist must first inform the public, but must also

explore the roots of the human condition as it is lived in South Africa: a grappling with essentials, with the fundamentals of human experience and human relationships, sup specie historiae. By keeping alive the voice of reason and the search for meaning in a demented world he offers a safeguard 
to human dignity and an awareness of human values. ("After Soweto" 152)

This search for alternative meanings is considered undesirable by the authorities, or 'aanstootlik' ('offensive'). It is in this act of offence, he claims, that the possibility of freedom is glimpsed ("Literature and Offence" 127). Brink notes that "the Greek word for 'heresy,' originally meant choice, which made of the heretic "one who chooses"' (qtd. in Miller 44). It is the notion of choice, he implies, which poses a threat to the fixity and stability of authority. In Brink's schema, therefore, the dissident position is not fixed, but centres on the possibility of choice in an arena of multiple alternatives:

literature has by its very nature a dissenting function in society, through its subversion of whatever dominant discourse holds sway at any given moment - even, and perhaps especially, when it has itself contributed toward the evolution of that discourse. That is why there can never be any final 'positions' in literature: whatever position is occupied at a certain time, or in a certain text, demands by its very existence the deconstructive scrutiny of its contemporaries and successors. (qtd. in Miller 56)

Inherent in this statement is a warning to those who adopt a dissident stance. Brink argues that "a culture of resistance can become a habit like any other" and warns against a literature which threatens "to become oppositional and only oppositional in the narrowest and most realistic sense of the word" (Reinventions 13). Littérature engagée must, he claims, continue to question its own stance, revising and renewing the challenge to that which is considered repressive. The effective dissident must be offensive in terms directly responsive to the injustices of her/his environment.

Implicit in Brink's articulation of the artist's antagonistic role is a notion of that artist's power to challenge. The suggestion of this power is interesting in the context of a prescriptive and censorial environment. Surely the artist is silenced by the censors? Brink, however, subscribes to a view that art outlives the censor.

\footnotetext{
${ }^{31}$ Notably, Brink claims that prior to the publication of Looking on Darkness, he had already begun to "introduce a political dimension" in his next novel, The Saboteurs, which remains unpublished
} 
Drawing on an essay by Afrikaans poet Van Wyk Louw, he describes how,

on the eve of his execution, a condemned writer is visited in jail by the head of state. The tyrant promises him a reprieve on the condition that he recant. If not, he will die and every word he has ever written will be destroyed. With quiet assurance the humanist elects to die, bolstered by the conviction that he will win in the end. 'How can that be?' the tyrant asks. 'I have two reasons,' replies the condemned man. 'One is that your executioner sees me die. The other is that you have found it necessary to visit me tonight.' ("Mahatma Gandhi" 56)

Brink's conception of the artist and of his art is that both remain a threat to the tyrant beyond their death or destruction. He notes, with irony, that "[i]n several countries a new awareness of South African writing has grown precisely because of the publicity given to the workings of censorship ("Failure" 145). In these terms, Brink claims, censorship "lent greater resonance to the words of writers" ("Failure" 11). Thus, he views South African censorship as a failed enterprise. ${ }^{32}$

J. M. Coetzee openly criticises Brink's idealisation of the artist's role in an article entitled "André Brink and the Censor". Delineating two distinct stages in Brink's conception of the artist's role in relation to the state, Coetzee challenges Brink's view. Initially, he claims, Brink's thesis is that "the writer triumphs in the end because his version of truth will outlast the antagonist's" (60). Brink's later model, he argues, is a more "complex" and "dialectical" relationship in which, like Antigone, "the writer affirms the higher authority of his own conscience" (60). This positioning gives rise to a tension between state and author in which the writer is compelled to undergo an ongoing assessment of her/his stance. This relationship is a "healthy" one, it is suggested, in which each party challenges the other in an ongoing renegotiation of their respective positions. Until, that is, they become "enemies", and the second model reverts to the earlier conception of the artist's truth outliving that of

\footnotetext{
("Introduction: A Background" 34).

${ }^{32}$ See "The Failure of Censorship" where Brink outlines the seven central tenets of censorship and argues that each of the tenets is ineffectual and has, in fact, led to further support for the dissident writer.
} 
the antagonist (60-1). Censorship, Brink argues, is the ultimate mode by which the reciprocal challenge, found in a healthy co-existence, converts to an unhealthy and destructive relationship: in these terms, the artist "is in fact an organ developed by society to respond to its need for meaning" (61). This society is sick, requiring healing, the artist its diagnostician. ${ }^{33}$ Coetzee analyses this metaphor, revealing inconsistencies in its representation. How, he asks, can the artist emerge in a society which enforces homogeneity and generates its own organs? Similarly, he critiques the assumption that the artist will always represent a 'healthy' stance. Further interrogations of the metaphor include questions as to whether diagnosis originates from within or without the body. If from within, Coetzee asks, how is contagion escapable? How can one escape ideological contagion or write from outside of one's historical moment? If from without, how does the organ return to the body? How can the exiled or alienated truly return in either literary or literal terms? The problems which plague Brink's metaphor suggest that the diagnostician can never be anything other than incompetent, tainted by the very disease s/he intends to diagnose and treat. "The problem", Coetzee concludes, "is ultimately not one of knowing what to say about the censor, but of finding a position from which to say it" (72). Here is Brink's ultimate paradox: he attempts to diagnose the state, but is himself a product of it; he both challenges and reaffirms apartheid tenets. The difficulty - arguably, impossibility - of locating a position beyond discursive authority from which to challenge a dominant hegemony will remain a latent concern in my examination of Brink's works.

Coetzee's overriding view is that Brink's "notion of the lone writer confronting the colossus of the state is excessive", redefining the relationship as one in which, "caught up in the dynamic of blaming, the writer cannot do without the state and its denunciatory organ, the censorship" (72). The oppressive state/dissident artist relationship is therefore mutually defining and co-dependent: the dissident and the censor operate under an adversarial relationship in which each reinforces the

\footnotetext{
${ }^{33}$ Brink clarifies that the artist's "domain is that of meaning, not of healing. But unless he performs his function and performs it well, and unless his diagnosis is heeded, healing would not be possible"
} 
position of the other. If the state were to revoke all censorial measures, then the reinforcement of the dissident's work would immediately cease. Likewise, the seditious artist must have a prohibitive environment or body to oppose. This view of mutual dependency derives from Coetzee's own deterministic literary and political philosophies in which he suggests that the writer is determined by her/his context and is therefore unable to effectively work beyond that context. In contrast, Brink's works suggest an ongoing search for a means of challenging one's ideological construction. Coetzee does, however, ultimately admit that the artist invariably articulates the last word, in her/his inevitable challenge to the judgement of the censors (63-4). It is art as a whole, I suggest, which provides an ongoing challenge, rather than an individual artist or artwork. Art represents an ongoing process of renegotiation in which representation is the subject: such an endeavour must question the status quo.

\section{Narrative Truth(s)}

" narratives are a primary embodiment of our understanding of the world,

of our experience, and ultimately of ourselves"

(Kerby 3 qtd. in Worthington 14).

The narrative self-consciousness of Looking on Darkness rehearses the ways in which narrative truths reflect both authoritarian and alternative positions. Joseph, as actor and narrator, speaks directly to the reader in a personal communication which refutes the authority of any court proceedings. Of the trial, he asks, "how could the case itself be other than disloyal to the truth of what had gone before?" (14). In response to what he considers the misrepresentations of his story, Joseph provides his own narrative, granting himself author-ity over his past, present and, ultimately, his future. In creating, communicating and destroying his narrative, he controls representation of himself and others, wrestling this authority from those who would narrate him in other terms. His story is his own, to fabricate, communicate or to 
destroy as he chooses. Ultimately, his text is destroyed, in an action which acknowledges his power over his own narrative: “[w] hat I'm writing here, I shall destroy as I go on. Otherwise they may get hold of it, and that may implicate too many others. Fortunately, the paper is very thin and it will be easy to flush it, page by page, down the toilet. In that way it will remain my own, which is all that matters now" (9). The freedom granted by such narrative in the text is perhaps its most dissident achievement. Power is placed with the individual, rather than with an external authority and thus, personal histories are seen to challenge the fixity and singularity of official historical record (137). Foregrounding a thematic concern with narrative authority, the author draws on narrative control or manipulation as a means by which to challenge authoritarianism, a model which structures his entire oeuvre.

The impossibility of Joseph's narrative, which has ostensibly been destroyed prior to his execution, but which is paradoxically communicated to the reader, creates a framework of narrative and textual interrogation by which the author and reader may ponder questions of narrative truth and fixity. ${ }^{34}$ After the destruction of Joseph's text, what remains is a series of misquoted Shakespearean sonnets transcribed onto toilet paper, a medium which in itself reflects the fragility of narrative stability or permanence and also the unreliability of the narrative voice. The misremembered sonnets contain alterations which shape the meaning to more closely mirror the themes of the preceding text proper. Focussino on love life as a staoe and men and 
deconstructive agenda of the novel as a whole. The textual fragility of Joseph's narrative suggests that the same pertains in all narrative, undermining the traditional reliance of South African political and social realities on fundamental religious, moral and political mythologies. Thus, evidence is given of both the power of narrative and, paradoxically, its fragility.

Looking on Darkness is an overtly inter-textual novel; recurrent references to the writings, teachings and philosophies of key literary and historical figures encourage the reader's consideration of the themes under examination. Inter-textual referencing incorporates a body of literary and philosophical material which reflects on human interaction and (in)equality. Likewise, the focus of each of the central characters is humanitarian and often explicitly dissident. Ranging from the flawed liberalism of Richard Cole, a romance writer frustrated by the overwhelming challenge posed to South African writers (335); to the more politically dissident Dulpert, Joseph's Coloured roommate who states his intention to marry a white woman (130), the cast of Brink's theatre of horrors covers the spectrum of political dissatisfaction. Minor characters such as Willem, expand the range of political view to include those who benefit from and are complicit in the system of oppression known as apartheid. Willem represents those who justify their role in this system by claiming their helplessness. At the opposite end of the spectrum are those who view violence as the only decisive act of challenge. The entire scale from complicity to active dissidence is represented. Thus, each of these characters mirrors aspects of Brink's own engagement with and frustration at the South Africa he returned to after experiencing the comparative freedom of Europe. Characters such as Jessica, a social anthropologist horrified at the injustices of the South African segregation laws, and sensitive to their effect on her lover Joseph, may represent those who, like Brink, wish to challenge the status quo. Likewise, Richard Cole may represent writers who, like Brink, feel overwhelmed by the literary challenges of the South African situation. He represents the unenviable position of a white South African liberal who must speak against his own people in order to be a true dissident: he is a 'traitor' to the laager. It is indicative of the environment experienced by each of these characters 
that they are all silenced, by various means, over the course of the text: Jessica is 'murdered', Joseph executed and Richard is struck metaphorically dumb with writer's block.

While drawing on the writings of others, the text itself is also permeated with its own narrative concerns. A variety of narrative forms are adopted in order to emphasise a thematic concern with the desire and the need to narrate oneself into the world. Altemating between Joseph's self-conscious prison narration in which he relates the events leading up to the trial, ancestral memories, miscellaneous memories of Jessica and the theatrical dramatisation of the trial, the text becomes a patchwork of narrative possibilities. This patchwork posits narrative as a creative and cathartic response to the horrific realties of the South African environment, both past and present. Ranging from the comedy of errors that comprise Uncle Juts' funeral and burial (31-2), to the Biblically enhanced versions of Joseph's ancestral history, the text offers narrative means by which to search for meaning. The examination of personal and collective desire to find meaning, begun in The Ambassador, is here a more forcefully articulated concern.

\title{
Searching for Meaning
}

\author{
"humanity also requires meaning, \\ or at least the opportunity to search for meaning."
}

(Brink "The Arts in Society" 50).

Theatre is the central form through which this search is undertaken. ${ }^{35}$ The theatrical is utilised not merely as a plot device, but also as a metaphorical tool to describe a sense of alienation and/or distancing from one's environment. Joseph uses theatrical form and language to express the feelings of alienation and shock he

\footnotetext{
${ }^{35}$ The text's theatrical focus is interesting in relation to the Black theatre being developed in South Africa at the time. Noteworthy is the significant number of plays Brink wrote during the period, suggesting his engagement with theatre as a form of challenge with direct, immediate access to one's audience.
} 
experiences on his return to South Africa from Britain, and also to narrate the trial proceedings (13ff) and his torture while incarcerated (256ff). The reality/unreality binary on which traditional narratives hinge is here blurred, in a confusion which undermines such categorical distinctions. Simultaneously, the theatrical allusions place Joseph, in moments of vulnerability and insecurity, as a spectator of his own life (17). This sense of helplessness reflects the same condition experienced by the masses of hegemonically disempowered South Africans Joseph represents. It is the undertaking of the text, and of Joseph, to wrestle with this disempowerment and to gain control of the narrative. In the text, theatre is the central medium through which this battle is staged. Joseph notes the manner in which theatre is, for him, a means of finding meaning, it is "more than a refuge: an opportunity to sort out the disparate elements of the world and make them intelligible to me" (131).

Ultimately, Joseph's search for meaning, through theatre, becomes a dissident challenge. His intention is to fulfil the requirements of dissent, as defined by Dulpert, that theatre "must force them to remember, not pamper them by allowing them to forget. They must never be allowed to forget. It's from remembering that revolutions are born" (137). Joseph states, "[a]cting as such was not enough. I had to discover, on the stage, an hour of truth as liberating as the matador's in a corrida; it had become a projection, a focal point, of the blind thought and feeling of an entire society. It had to break down all the conventional barriers" (183). Joseph's involvement with a travelling band of Coloured actors who perform traditional plays adapted to reflect their own specific realities (215), represents the renegotiation of historical and literary narrative. The actors reappropriate canonical works, usurping the author-ity of the white authors of literature and the historical. In doing so, they produce living texts more relevant to the social and political realities of themselves and their audiences. Their production of Romeo and Juliet is exemplary, a canonical work reinterpreted for a South African reality, in which the Coloured Romeo and the White Juliet mirror Joseph and Jessica (245). In a further example of narrative's potential for mutability, Joseph remains obsessed with the notion of playing a Coloured Hamlet (134), a role awash with dissident possibilities and which 
metaphorically reflects on Joseph's own dissent. Quoting the iconic character, he states, "the play's the thing wherein I'll catch the conscience of the king!" (222), a specific and overt challenge to the South African authorities. Joseph's group, however, soon discard their initial dependence on canonical forms, developing their own material based on their experiences. Their production of $S A$ ! is exemplary in its narration of what may or may not have happened to Dulpert (306).

Reflective of the censorial environment in which Brink created this work, his characters are also subjected to increasing authoritarian harassment and censorship. Of interest is the scene in which the group are prevented from performing $S A$ !, the riots which ensue mirroring the events in the play: art speaks to the reality depicted in the novel, and vice versa (309ff). Ultimately, the text of the play is banned by the Publications Control Board (310), an action eerily predictive of the banning of Looking on Darkness itself. Joseph's attempts to "produce theatre which has something to say" (318) are all too effective: the authorities silence him before he becomes a greater threat.

The search for meaning, expressed in various forms, permeates this, as in earlier, texts in a series of artistic representations. Frequent references to pictorial art, for example, and the interpretation of that art, foreground artistic expression as a means of attempting to find, and narrate, place and identity (182). Likewise, Joseph's ancestors provide a precursor to his own search as they each 'perform' in the contexts of their respective historical moments. The illiterate Moses, for example, recites songs and rhymes for bystanders (39), Dlamini/Daniel plays music (44), Abraham writes poetry (57), and Joseph's mother narrates the family history (35ff). Each of these characters has been denied voice, yet narrates her/himself into being/history by alternative means. This ongoing expression of identity refutes the authority of the hegemonically empowered, as does Joseph's (impossible) narrative. At each narrative level, therefore, characters challenge their silencing, countering the process that censorship laws merely formalised. 
In each of the searches in the text, 'truth' is the ultimate goal. Joseph's narrative, he explains, is a means by which "to fight [his] way through a web of syntactic certainties towards a final, possible glimpse of truth" (8). Joseph's 'truth', however, must be redefined in order to 'mean' something: "Truth is not a collection of facts which can be narrated but a landscape through which one travels in the dark" (34). For Joseph, as for the text as a whole, 'truth' lies beyond the factual; it is an exploration of possibilities rather than a final conclusion. ${ }^{36}$ Thus, the "facts" of Joseph's trial are not merely contested but their very possibility is undermined. Family mythologising (58), and doubts and suppositions in the narrative (66, 37ff), reflect the ongoing narrative possibilities traditionally denied in totalitarian environments. In addition, the intermingling of Biblical stories with ancestral memories denies the distinction traditionally upheld between authoritative versions and personal anecdotes while simultaneously questioning this distinction. The interweaving also undermines the exclusivity traditionally associated with religious belief and narrative. Upheld as a text which ostensibly both justifies and teaches prejudice, the Bible has been traditionally touted as 'belonging' to the hegemonically empowered of South Africa. The invocation of Biblical names and references in the narrative of Joseph's Coloured ancestors is therefore a revolutionary act which refutes the religious exclusivity of Calvinism and its proponents. The ongoing process of narrative re-creation is enacted here: 'truth' is renegotiated.

\section{The Historical Search}

"All that is history, but once again our family passed by on the shadow side" (Brink Looking 67).

In a similar refutation of the sanctioned 'truth' of the empowered, the text describes the experience of exile from one's historical moment and renegotiates this historical positioning by narrative means. Joseph's ancestor Abraham is the physical

\footnotetext{
${ }^{36}$ See Dixon's "Shouting against Silence: André Brink's Voices of Truth.", "Personal and National Knowledge in André Brink's South Africa," and. "Stories or History?: Female Counter-Narratives in
} 
exemplification of those who feel themselves continually on the brink of, but excluded from, history. He metaphorically represents one alienated and exiled from an exclusively white rendering of history; he exists on the "shadow side" (67) of history. During Joseph's narration of his ancestral stories, he often pauses to comment on this breach between personal and authoritative histories: "strange to think how little of the country's official history appears in my chronicle, as if we've always existed apart from it" (48). It is not until Abraham lies dying, telling the stories of the battles he had missed as if he had actually been there, that he is "accepted by history" (62): re-creation gives him a voice and a place in history. The series of narrative possibilities in the text offers a means of representation to those silenced by hegemonic fixed and singular historical records.

History, it appears, is the predominant means by which personal and collective identities are negotiated and understood. Throughout the text, the traditional assumptions of historical record are juxtaposed against the personal experiences of Joseph and his ancestors in a series of (subtle) interrogations of history (e.g. 37). Additionally, recurrent references to history foreground its importance as a means of representation and understanding of the past and of the present. After his return to South Africa, for example, Joseph revisits his homeland "in search of traces of [his] history" (231), a recurrent refrain in the text (see e.g. 59).

The exploration undertaken by the novel's protagonist and narrator is a search for self-knowledge by narrative means. The ancestral narrative of Joseph's family provides a model for narrative exploration and illustrates the importance of narrative re-creation and the comfort derived from it. Joseph notes of his mother, "[t]o her, our story, despite the twists and turns she gave it in her manifold renderings, was the one abiding thing of comfort and pride and respectability in a life which all too often experienced the defeat of the spirit by the flesh" (35). Ultimately, Joseph is not merely a link, but also the conclusion to an ancestral narrative chain of pain and suffering (43). It is not unreasonable, therefore, that when the experience of 
imprisonment and torture becomes unbearable, Joseph chooses to absent himself from the present by drawing on his ancestral past (259). Joseph attempts to convince himself, and the reader, that there is freedom in the narrative of his ancestors and in his own choice to suffer as they have done before him. In the concluding pages of his text, he states, "I'm not alone tonight, they are all with me, the long dark row. I am not a victim of my history. What happens, has been chosen by myself. I do not undergo it, I create it" (393). Joseph's existentialist claim refutes the power of those who oppress and silence, but is problematic in its insistence upon a 'choice'. Joseph claims he has chosen to suffer, an existentialist choice of endurance, as opposed to the relief of death. Ultimately, however, each of these 'choices' is prescribed by the oppressor, who is granted the only true freedom of choice.

The search for identification, a fundamental thematic concern in The Ambassador, is also a crucial component of the search for meaning in this later text. The novel commences with the phrase, "[t]o know who I am" (7) - outlining a central concem with identification which permeates Brink's oeuvre. The search for (personal) meaning is an individual response to the prescribed identity and preclusion of alternatives required in oppressive and restrictive environments; the search is for identification beyond the confines of authoritarianism and the acceptable, stultifying image this demands. The desire to discard an ordained and delimiting identity in favour of an alternative represents a direct challenge to totalitarianism and is, in these terms, of political significance - it is an act of dissidence.

Similarly, the text as a whole is politically dissident in its undermining of the prejudicial foundations on which apartheid legislation and its policing depend. Joseph Malan is depicted as a 'normal' human being: his intellectual, moral and social interactions are no less complex than those of his white counterparts. Thus, the traditional justifications for the prejudicial treatment of white South Africans, in which they are cited as superior in intellect, morality and socialisation, is undercut in the characterisation of Joseph. His equality in these terms offers a challenge to a system which denies basic human rights to those classified as racially inferior to 
those in power. In the text, Joseph represents Coloured South Africans who have consciously rejected the terms under which they are disempowered, and who search for a new identity beyond the prescriptions which deem them inferior.

Joseph's search for a new, alternative identity is framed in ways which speak not merely of selfhood but also of the self's relationship to the other. Joseph's romantic and sexual relationship with Jessica metaphorically envisages the crossing of racial boundaries policed under apartheid. Responding directly to an environment in which legislation such as the Immorality Act constrains social interaction, miscegenation is arguably the most dissident aspect of the text in its blatant refusal of racial segregation, the very basis of apartheid ideology. ${ }^{37}$

In the text, one's sense of "place" is inextricably linked to "knowing your place" (267, 383, 393), suggesting a correlation between the manner in which geographical and societal prescriptions operate. In the South Africa of the text, one's spatial allocation is determined by one's sense of "place" in the prejudicial hierarchy of race: one must live in the social and spatial boundaries determined and policed by white South Africans. Thus, an ongoing search for a sense of belonging includes a search for a "place" in which to feel secure. For Joseph, this place is the stage, a "home" where he is momentarily freed from the strictures which his society imposes on those of Colour (15). Despite his continued insistence that South Africa is his "own place" (204), Joseph's treatment at the hands of his oppressors suggests that he has no "home" except as determined by the authorities or, alternatively, as he himself imagines. Joseph's alienation from a homeland which he feels is his own, but with which he is refused a meaningful relationship, is most powerfully exemplified after his return from Europe. In London, he suddenly realises his feelings of estrangement from his environment and is prompted to return "home" (189); his epiphany and his sudden return home mirror Brink's own experience. Renewing his acquaintance with the place of his birth, he describes a "vast country which was mine and which I hardly

\footnotetext{
${ }^{37}$ An in-depth discussion of the theme of miscegenation is deferred to the next chapter.
} 
knew" (221), a comment which speaks to the metaphorical exile of the majority of South Africans from their birthright during the apartheid era.

The ongoing and overarching concern with narrative as a means of representation is evident in this text and indicative of Brink's continuing concern with narrative expression throughout his oeuvre. The demonstration of, and concern with, the constructed nature of narrative speaks to the manner in which narration may be used not merely as a weapon of oppression, but also as a tool of dissent. Brink's text illustrates the manner in which narrative may be fixed and espoused as the 'truth' and subsequently used to justify oppression and abuse. He argues, however, through means of his own narrative, and those of his characters, that narration may also offer the possibility of refutation, of freedom against the prescribed 'truths' of those in authority.

\section{Religion Undermined}

"I'm Coloured, Mr Joubert. Surely you don't expect me to believe in God."

(Brink Looking 12 ).

The espoused 'truth' of religious scripture is one of the central claims Brink undermines throughout his oeuvre, and with which he engages in this text. Deployed as the foundation of Afrikaner belief and of apartheid ideology, the fundaments of Calvinism have been traditionally upheld in South Africa as justification for the oppression of non-white South Africans. Based on the central tenet of Biblical segregation, apartheid is the epitome of the ideology of exclusivity and exclusion. As Joseph's white childhood friend, Hermien, explains to him, "[w]e whites are the children of Shem and Japheth and you are the children of Ham and his son Canaan. That's why it is like that" (77): Joseph's people bear "Cain's mark" (233) and are subsequently submitted to a 'destiny' of abuse and oppression. 
Central to Brink's undermining of religiously justified white superiority is his demonstration of the constructed nature of religious narrative and its subsequent 'truth' claims. The deconstruction of religious 'truth' has been sufficiently explicated in the chapter related to The Ambassador, and it is therefore unnecessary to reiterate these claims except to note its continuation, in similar terms, in this novel. It is noteworthy, however, that Brink's deconstruction of religious certainty and the subsequent loss of faith demonstrated in The Ambassador is developed here into a specifically atheist position, in the character of Joseph. He looks back to a period when "the Bible still mattered" (18) to him and when Jessica asks him if he is a "believer", he responds, "[n]o. But I'm trying. I wish I could. But sometimes it seems to me that faith must be a thing like innocence, something one loses" (283). Speaking of a role he played in a production of Six Characters in Search of an Author, he claims that he cannot believe in God "any more than the Son could believe in the existence of his Writer" (250). Here he articulates not merely a loss of faith, but his awareness that this loss also represents the loss of author-ity, of a means by which to frame one's existence and actions, demonstration of the existentialist angst of the individual.

The insistence on religious imagery and reference in the text acts as an illustrative counter to Joseph's atheist position and provides a contextual frame of reference for his resistance to the authority of fixed and prejudicial 'truth'. His upbringing, and the environment in which he lives continue to bombard him with religious images and language now devoid of their context. Thus, religious phrases resonate in the text as meaningless liturgies: "by his one oblation of himself once given: to the contrary notwithstanding" (323). However, despite his denial of religious belief, Joseph continues to be plagued by his past faith. He is haunted by a religious text which Jessica told him hung above her bed as a child: "Thou God seest me" (19). The warning points to specific aspects of surveillance and judgment, and the 'censorial' aspect of these. During Joseph's imprisonment, this notion of an allseeing authority is re-envisaged as the bare bulb which continuously lights his cell $(30)$. 
Most clearly indicative of Joseph's inextricable link to the religious faith of his past is his metaphorical and literal search for grace. His narrative is a confession, a final testament in which he explains the context of his 'sin'. In a manner reminiscent of scenes from The Ambassador, Joseph sins, confesses, and awaits the grace of forgiveness. Notably, the text itself provides definition of a grace specific to its context: Father Mark notes that grace is "[n]ever to confuse our resistance with hate. To have that love which makes resistance meaningful" (325). Grace, for Joseph, is defined in a specifically dissident context, in that it is granted by virtue of one's intention, rather than one's actions. Thus, for those who may commit violence, such as Jerry (392), or Joseph, the sin is expiated by the sincerity of the action, by the desire to challenge oppression and suffering, rather than to perpetuate it - this distinction is important in light of later texts. Here Brink reveals the extent to which, for him, morality is defined in religious terms. The ongoing paradox in which Brink overtly challenges Calvinist tenets, yet continues to implicitly reaffirm them in the novel's structure and narrative, is similarly demonstrated.

Brink's own challenge to Christianity is most powerfully realised in his conflation of the character of Joseph with key Biblical and historical characters. Undermining white possession and control of the Biblical text, in particular, Brink associates Joseph with various central Biblical figures in order to undercut the exclusivity asserted in Calvinist renderings of the Bible. Joseph, a Coloured South African, is metaphorically aligned with the two Biblical Josephs, each of whom plays a central role in Biblical narrative. A childhood memory of a nativity play resonates in the text, recurrently linking Joseph to his Biblical namesake(s). Joseph wanted to act the role of the Biblical Joseph in the play, but was refused because of his colour. Ironically, further resonance is supplied by the boot-polished face of the white child playing one of the three Magi: Joseph asks: "if you play again nex' year... c'n I be the black men?" "Course not" Thys replies. "How can you? You're not white" (81). Again, the text's central questions of "[w] ho am I?' and “[w] here is my place?" (88) cannot be answered in a prejudicial context. In adulthood, Joseph confronts the white 
child who played the role of Joseph: he tells Willem, "you were Joseph. Which created quite an ontological problem for myself: how could Willem be Joseph if Joseph was Joseph?" (216).

Most strikingly, Joseph is frequently likened to Jesus (206) and is specifically aligned with His suffering. Jerry, challenging Joseph's dedication to the dissident cause, frames his concerns in religious terms: "[y]ou want to set people in motion like Christ" (296). ${ }^{38}$ Likewise, Joseph views himself in Christ-like terms, likening his suffering and imminent execution to that of the sacrificial, crucified Christ figure, while simultaneously invoking images of transubstantiation to suggest that while his body will be destroyed, a part of him will live on (in his narrative) (14). The suggestion of a Coloured Christ figure inverts the traditional association of Biblical and authoritative icons with white skin, critiquing and undermining the bases on which religious exclusivity is founded. In discussion related to publications deemed blasphemous, J. C. W. van Rooyen notes that although opinion on the matter varies, the majority of Christians do not regard the portrayal of Jesus Christ in drawings, paintings and on film as offensive provided it is done without violating fundamental beliefs regarding his life on earth. Minor deviations from such beliefs are permitted in the interests of drama and literature; such deviations must, however, be either unimportant or merely annoying, but not offensive. (91)

In these terms, and in the context of religious beliefs premised on the superiority of whiteness, the Coloured Christ figure of Joseph may well be considered 'blasphemous'.

\footnotetext{
38 The ongoing debate surrounding non-violent versus violent means of protest is central to both Brink's work and the South African situation and is further addressed in chapter nine.
} 


\section{Political Dissidence}

"The Law is my Shepherd"

(Brink Looking 226).

Just as Looking on Darkness develops the challenge to religion posed in The Ambassador, it also engages more overtly with the political realities of South Africa. Brink's previous publication, The Ambassador, challenges Afrikanerdom, citing its prejudices and irrationalities and critiquing them, but ultimately fails to politically engage with its subject matter. In contrast, Looking on Darkness offers a more specifically political challenge in its critique of the segregational practices of apartheid South Africa, particularly in its challenge to the laws on racial segregation and the prohibition on marriage between White and Black South Africans. The novel is a testimony to the various oppressions of the apartheid era, cataloguing examples of revolutionary violence, black resistance, censorship, detention without trial, murder, torture and, most pointedly, the enforcement of the Immorality Act. In terms of an overt political challenge, Joseph's narrative is dissident both thematically and technically. Thematically, the miscegenation exemplified in the sexual and emotional relationship between Joseph and his lover Jessica challenges the segregational legislation by which the prejudicial oppressions of apartheid are upheld. Technically, Joseph's narrative represents the "No!" of Antigone (242, 267, 335-6), or, alternatively, the critique posed by Hamlet (335), each of which recur throughout the text as metaphors of refusal and challenge to dictatorship. In these terms, Joseph represents South African dissidents, traditionally, excluded, denied, oppressed and silenced, contesting their oppressors.

The restrictive and oppressive environment which Joseph challenges is clearly described and (often ironically) critiqued in the text. During Joseph's trial, the court hopes "to establish beyond all doubt that the relationship between the accused and the deceased had reached a point beyond which it could no longer continue in the framework of the laws and the traditional way of life in this country" (16). These 
laws and traditions are the focus of Joseph's and of Brink's protest. The author includes a series of historical markers in order to construct an environment of oppression and to justify the attitude of dissent. The events at Sharpeville are drawn on (143ff), as is the destruction of District Six (194ff). These are politically iconic moments in South African history on which Brink's text is appended and within which it is contextualised. They offer a context for the reader, a key by which the fiction may be read and understood as a dissident challenge to apartheid.

Opposing the authoritarian environment in which 'truth' is singular and fixed, Brink creates one of intellectual and physical alternatives and possibilities. Joseph's roommate, Dulpert, in particular, is a vehicle by which alternative philosophies, politics and religions are introduced into Joseph's previously limited realm. The Calvinist foundations of apartheid South Africa, for example, are met with a myriad of spiritual alternatives: Hinduism, Buddhism and devout heathenism take their place within the realm of possible forms of belief and worship (127). In this way, the exclusivity and exclusion of Afrikanerdom and its religious, moral, social and political forms of control is undermined. Later, Harry Tsabalala and Jerry Buys take on Joseph's 'education', introducing him to the intellectual and religious possibilities previously denied him. Suddenly exposed to the music of Lourenço Marques Radio and Radio Bantu, to the theories of Camus, Fanon, Stokely Carmichael, Leroi Jones and Eldridge Cleaver, the words of Mandela and Bram Fischer's statement from the dock (255-6), Joseph realises the delimiting environment in which he has existed. In the context of apartheid South Africa, these views are clearly dissident.

The creation of an environment of alternative possibilities to hegemonic Afrikaner rule provides a means by which to critique specific political injustices. Throughout the text, the author cites instances of legislative and social injustice, overtly and repeatedly. Examples of his literary engagement with the specifics of the South African context include mention and critique of the Immorality Act, apartheid as a whole, violence, revolution, Black power, censorship, the 180 day detention legislation, legal injustices, racial discrimination, disappearances and suspicious 
deaths, torture and an implied association with the ANC in relation to Jerry Buys. Further overt dissent is evident in the performance of Life is a Dream, the plot of which explicitly posits a challenge to white rulers, with its threat of an apocalyptic future (238-9). Also evident is an ironic overtone that ridicules the current regime and its dogmatic justifications. Joseph, for example, relates how the authorities answered accusations of brutality after a child was mauled by a dog while police dispersed a crowd waiting to see the cancelled $S A$ ! production. He states, "[e]nquiries had revealed $[\ldots]$ that the child's parents had deliberately tried to provoke an incident by thrusting her unto the dog's mouth" (310). It is Joseph who articulates the most blatant political dissent, challenging Willem, the metaphorical representation of Afrikanerdom. Joseph proposes,

[s]uppose my people were governing this country and decided: from tomorrow white Afrikaners will have political rights in the Orange free State only. You're all repatriated - but we keep the gold and diamonds for ourselves, of course; and if you set foot outside the Free State, you must carry a pass and keep out of our theatres and schools and restaurants and trains and lavatories and churches: and you're not allowed to have property outside the Free State or to earn as much as we do for the same job.... (347)

This imagined inversion of oppression is the apocalyptic future feared by the empowered.

\section{The Politicised Dialogue}

"a dialogue with my own society"

(Brink "André Brink Talks" 4).

Looking on Darkness clearly demarcates the point at which Brink's work may be labelled dissident. His direct critique of the socio-political context of South Africa, in both content and theme, is therefore a significant development of his more naïve challenge in The Ambassador. Apropos of the Sestigers, Brink notes, "towards the end of the sixties, after having broken the taboos of morality, of sex and so on, in 
Afrikaans literature, we realised that one of the greatest taboos still had to be broken, that was politics" ("André Brink" 55): Looking on Darkness breaches this final taboo. Notably, two significant historical events framed the inception and completion of the novel, arguably providing political prompts for the author: the text was begun when the Sharpeville massacre occurred in 1960, but was not completed until after the Paris riots of 1968 (Goldblatt 97). From the publication of this text onwards, Brink's work becomes increasingly dissident, openly critiquing his society and those who govern it. He himself cites a "growing militancy" in the books and articles he published in the 1970s ("André Brink Talks" 5), and a consequent intensification of authoritarian interest in his activities. Faced with increasing contestation from both Black and White South Africans, the authorities responded to this 'threat' quickly and forcefully. For the first time, censorship was invoked to silence dissent from within the Afrikaner laager. Brink notes that the works of the Sestigers "led to an increasing wave of intimidation and eventually repression" of Afrikaans writers which had previously been experienced predominately by English and Black writers ("Failure" 143).

Just as Brink's renegotiation of representation was evident in The Ambassador, in its exploration and critique of Afrikaner identity, the renewed social commitment claimed after Brink's second metaphorical rebirth is evident in Looking on Darkness. Brink notes that "no text can ever emerge in a vacuum", that "the politics may not be overt: but it is there - in the sense that every written line is produced by the pen and the mind of a woman or a man who is herself/himself the product of a particular time and place, a particular society, a particular historical juncture" (Reinventions 20). This may be true of The Ambassador; Looking on Darkness, however, clearly represents an overt engagement with the politics of his place and time and an open challenge to the apartheid state. Contextually, the novel speaks both to and of South Africa. Refusing to adhere to ideological conformity, the text poses a threat to the hegemonically empowered, in its suggestion of alternatives.

It is for this reason that Looking on Darkness was censored. Brink clearly 
views literature as a mode of expression with the possibility to promote, indeed provoke, social change. This text reflects the censorial nature of Brink's environment in two central ways: it is a dissident response to the prohibitions and prescriptions of a censorial milieu and it is also a victim of the censorship apparatus. Simultaneously, the novel raises questions as to the nature and role of censorship in its various forms. It treats the prohibitions and prescriptions of the apartheid regime and also the specific censorial apparatus in place. The censorship of this text offers evidence that Brink's dissent against the state is seen as a threat: the novel speaks 'truths' to counter the 'lies' of the apartheid state. Speaking of the original Afrikaans text, Brink notes that it contains so much material that the majority of his later novels are elaborations of themes found in the earlier text. ("Interview" n. pag. qtd. in de Lange 51). Thus, the search for identity, place, and truth, beyond the boundaries of the authoritarian or the censorial, that 'cultural conversation' begun in The Ambassador and resumed in Looking on Darkness, must now continue. 


\title{
CHAPTER 3
}

\section{Black/White Relations in \\ An Instant in the Wind and A Dry White Season}

\author{
"All I was aware of was distance. \\ I could touch him, but it wouldn't bridge the space between us. \\ He, I. Black, White." \\ (Brink Wall 428).
}


South African literature focuses, to a large extent, on notions of exile because this theme speaks of the context in which that literature is created:

One could nearly postulate that South Africa is the homeland of exile. There are many kinds of banishment: the physical one [...], but also a spiritual or cultural one when people have to use the language of the colonizer; then there is the exile of Afrikaner writers in South Africa itself, those who have no true insight into the South African reality because of the restricting laws or an induced tribebound blindness; and the political exile of those whose works are quite simply forbidden in the country. (Breytenbach, "Conflict and Literature" 77)

Technically, the state of exile implies a process of expatriation, in that one is excluded from a group or place to which one previously belonged. My use of the term is slightly irregular in suggesting that the identification with a group and/or place is an ideal, or idealised one, rather than an experience previously enjoyed and since denied - the subject is excluded from what s/he imagines as a just society. The experience of exile is the loss of an imagined ideal, and the desire for a return to this holistic state in which people are accepted on their own terms. ${ }^{39}$ David Bevan's definition of the exilic experience is helpful in this regard. He focuses on marginality or alterity, rather than physical distance, as the defining feature of the exile:

exile, in its broadest sense, is not only a specific historical circumstance, it is also a constant of our common predicament. In this the evident particularity of political displacements may be merely a symptom or an image of some other form of estrangement: womanhood, the Third World, migrant labour, apartheid, colonisation and sundry further estates of marginality. Indeed exile within a place is often still more poignant than exile from a place or exile to a place. Exile, viscerally, is difference, otherness. (3)

The 'exilic' experiences of South Africa and its inhabitants and their longing for identification and belonging will be relevant in the following discussion related to the ongoing negotiations of self/other pairings.

\footnotetext{
39. This imagined place of belonging and acceptance is often described in physical terms. Black Nationalists speak of a future post-apartheid South Africa as the free land of 'Azania'.
} 
In the previous chapter I outlined the censorial environment of South Africa in which notions of identity and expectations of behaviour are circumscribed by an authoritarian regime. As suggested in Looking on Darkness, apartheid South Africa was framed by a prejudicial apparatus of government and judiciary designed to segregate the racial other from white - specifically Afrikaner - South Africans. It was a means by which to alienate the self from the threat of the racial other. This exclusionary process was fundamental to the original colonisation of South Africa and subsequent interracial relations. In Giving Offense, J. M. Coetzee records the role colonisers played in constructing binary oppositions to label self and other:

$[w]$ hen Europeans first arrived in southern Africa, they called themselves Christians and the indigenous people wild or heathen. The dyad Christian/heathen later mutated, taking a succession of forms, among them civilized/primitive, European/native, white/nonwhite. But in each case, no matter what the nominally opposed terms, there was a constant feature: it was always the Christian (or white or European or civilized person) in whose power it lay to apply the names - the name for himself, the name for the other. ( 1 ; original italics)

This binary model is reflected, critiqued and undermined in the texts under discussion in this chapter.

Brink's objective to engage in a 'cultural conversation' with his society continues in the two texts under examination. An Instant in the Wind (1976) ${ }^{40}$ continues the exploration of the theme of miscegenation, first introduced in Looking on Darkness. The later text provides an historical depiction of interracial contact as a metaphor for contemporary interracial relations in South Africa. The discussion then turns to Brink's A Dry White Season (1979). ${ }^{41}$ Although arguably a lesser text in terms of literary technique, the novel is discussed as a further example of Brink's analysis of interracial concerns. The black/white friendship described in this text

\footnotetext{
${ }^{40}$ The Afrikaans edition, n'Oomblik in die Wind, was originally published in 1975.

${ }^{41}$ The Afrikaans edition, ' $n$ Droë Wit Seisoen, was originally published in 1979.
} 
treats interrelational issues similar to those in Looking on Darkness and An Instant in the Wind, but in an asexual manner. Simultaneously, the text specifically describes the social and political realities of contemporary South Africa, demonstrating Brink's renewed intention to engage politically with his environment.

Arguably, An Instant in the Wind most fully explores the theme of miscegenation latent in the majority of Brink's work. The novel develops the concems of Looking on Darkness, in which Joseph's romantic and sexual relationship with Jessica metaphorically envisages the crossing of racial boundaries policed under the apartheid regime. This largely idealised form of union mirrors the African understanding of ubuntu (or umbuntu), a concept based on the belief that "a person is a person through other persons" and foregrounding ideals of sharing, generosity, hospitality, and love (Tutu 1). In Brink's text, ubuntu is offered as an alternative to the exclusionary practices of apartheid. Joseph and Jessica tell one another "This is you" (23): recognition of another, it is suggested, is the means by which the reconciliation and harmony proposed in Brink's essays may be achieved. ${ }^{42}$

Looking on Darkness and An Instant in the Wind respond to segregational constraints such as those imposed by the Immorality Act; miscegenative acts blatantly refuse racial segregation, the very basis of apartheid ideology. Brink's liberal treatment of miscegenation as a central thematic concern challenges its traditional depiction in South African literature. Seminal South African texts such as Sarah Gertrude Millin's God's Step-Children represent the 'tragic' consequences of miscegenation, a warning to those who would cross racial boundaries. As Sander Gilman asserts, prohibitions on miscegenation are premised on fear, not merely of sexual interaction with a racial other, but also the ostensible result - a decline of the (white) population (107). Millin's treatment suggests both an obsession with, and anxiety regarding, miscegenation as representative of the Afrikaner fear of the other. In striking contrast, in Looking on Darkness, the coloured Joseph develops a sense of self-awareness through social, romantic and sexual interactions with Jessica, who is

\footnotetext{
${ }^{42}$ See, for example, "On Culture and Apartheid".
} 
white. As in The Ambassador, one's identity is reflected in how one is viewed by another. If Joseph is representative of self, Jessica epitomises the other. In contrast to his gender, race, citizenship and social standing, she symbolises the binary opposition of all that categorises him: she is female, white, foreign and yet (somewhat paradoxically, in terms of her gender and foreign status), empowered. Thus, the couple represent a renegotiation of traditional self/other pairings and the rejection of segregation in favour of communion and understanding.

Gilman argues that the 'stereotypes' which determine and define otherness reflect the insecurities of selfhood. He notes, "Although this activity [the activity of stereotyping] seems to take place outside the self, in the world of the object, of the Other, it is in fact only a reflection of an internal process, which draws upon repressed mental representations for its structure" (18). Further, he argues,

The categories into which stereotypes can be divided [...] are not arbitrary. They are bipolar but are mutable and constantly shifting. They reflect certain basic perpetual categories, which are in turn projections of internalized, often repressed models of the self and the Other. All of the categories reflect the cultural categories of seeing objects as a reflection or distortion of the self. The resulting basic categories of difference reflect our preoccupation with the self and the control that the self must have over the world. Because the Other is the antithesis of the self, the definition of the Other must incorporate the basic categories by which the self is defined $(23)^{43}$

Further, Gilman argues that "[T]he very concept of color is a quality of Otherness, not of reality", and describes both blackness and whiteness as "mirage" (30). Therefore, to embrace the sublimated other is to acknowledge previously denied aspects of one's own selfhood, inter alia, shared geography, ancestry and history. In Brink's texts, it appears that all prescriptive identifying terms must be renegotiated: notions of self and other and the interactions between the two must be examined and renegotiated in a search for new meanings from which to move forward. This overarching political message was latent in The Ambassador, more fully developed in

\footnotetext{
${ }^{43}$ Saul Dubow's Scientific Racism in Modern South Africa is useful in this respect.
} 
Looking on Darkness and permeates the remainder of Brink's oeuvre. I will examine the theme as it appears in An Instant in the Wind and A Dry White Season, using these two quite different treatments as representative of Brink's engagement with these issues throughout the remainder of his oeuvre.

\title{
An Instant in the Wind
}

\author{
"Here I am, explore me"
}

(Brink Instant 41).

In 1836, the Stirling Castle was shipwrecked off the Queensland coast of Australia. The Captain's wife, Eliza Fraser, was marooned with a number of the ship's crew and captured by Aborigines but ultimately returned to 'civilisation'. The island on which this occurred has since been named Fraser Island, in her honour. In the context of early Australian history, the incident is viewed as an iconic narrative of first contact. The ensuing mythology surrounding the event demonstrates how Australia's narratives of nationhood and identity continue to be shaped by colonial encounters: the story is retold in popular myth, music, literature, art and film and has instigated a body of scholarly research. ${ }^{44}$ In 1976, Brink published his account of the event entitled An Instant in the Wind. The novel is set in early 1749 in South Africa and focuses on miscegenation in order to comment on the oppressive and segregational nature of both historical slavery and apartheid in South Africa in the 1970s. Notably, the text's release was counterpointed by the Soweto Riots, providing a contextual framework which emphasises the novel's contemporary relevance.

Brink's novel is framed as an exploration, an answer to the question posed in the text's opening words: "[w]ho were they?" (9). Recurring throughout the novel in various forms, this question foregrounds the continuation of Brink's overarching

\footnotetext{
${ }^{44}$ See, for example, Kay Schaffer's In The Wake of First Contact: The Eliza Fraser Stories and Constructions of Colonialism: Perspectives on Eliza Fraser's Shipwreck by Ian J McNiven et al. .Australian writer Patrick White published his fictional account of the Fraser story, A Fringe of Leaves in the same year as Brink's novel.
} 
theme to this point in his writing: identity and its representation. More specifically, his investigation focuses on notions of selfhood and otherness. Theorists Hélène Cixous and Catherine Clément remark on "a commonplace gesture of History: there have to be two races - the masters and the slaves" (qtd. in Young 1), "[t]here has to be some 'other' - no master without a slave" (qtd. in Young 70-1). ${ }^{45}$ Brink begins with this premise and its particular rendition in South African terms. Identity is thematically explored and used as a means by which to examine interracial relationships which speak to the segregational context of South Africa at the time of writing. ${ }^{46}$ An Instant in the Wind offers a response to a specific segregational context and, in doing so, examines not merely the individual identities of Adam/Aob and Elisabeth, but also uses these protagonists as symbolic of black/white interrelations. In the novel's concluding pages, as Adam and Elisabeth spend a last night together on the beach at the Cape, the phrase recurs: "[w] ho are you? I have never known anyone better. Yet you are altogether strange to me" (249). The question framing the text is refocused in an acknowledgement of the inability to fully 'know' another. As the novel concludes, with soldiers bearing down on the waiting Adam, the narrator imagines them asking him, "[w] ho are you?" (250), bringing the examination of identity, prejudice and relationships to a close.

In relating the manner in which prejudice is displayed, challenged and discarded and imagining the growing understanding and love between man and woman, black and white, mistress and slave, Brink traces the possibility of interracial reconciliation in the South African context. He also relates the manner in which prejudice is ultimately upheld, metaphorically representing the betrayal of mutual understanding: the image of Adam standing alone, awaiting his capture and punishment, reflects similar results in a South African milieu. Likewise, Elisabeth returns to her own form of enslavement, in which she is also 'betrayed' by society. Thus, their respective experiences of betrayal correlate to those of the apartheid state

\footnotetext{
45 Refuting such simplistic pairings, however, is Young's criticism that this model fails to acknowledge the multiple layerings of prejudice and oppression in operation at any time (5).
} 
- in none of these situations is there any possibility for positive intercourse. In these terms, the novel is pessimistic in tone, and yet also offers the possibility of alternatives to segregation and oppression. The text suggests, therefore, that South African society, as it stood at the time of writing, was not ready to assume the responsibility for engagement with the other - simultaneously, it offers interrelational contact and mutual understanding as a future possibility.

In An Instant in the Wind, co-defining relationships are symbolised by the juxtaposition of the Cape and the wilderness. Neither setting has any meaning except in relation to its opposite: the notion of 'civilisation' is dependent on a conception of that which is not 'civilised', the wilderness. Adam's escape to the 'freedom' of the wilderness thus defines civilisation as a place of confinement. The co-definition of Cape and wilderness reinforces the co-defining bonds described in terms of self and other as exemplified in the relationship between Elisabeth and Adam. Elisabeth's fear that her individuality will be subsumed in an engagement with Adam represents a justification for Afrikaner exclusivity. The Afrikaner, prior to and during the apartheid era, excludes the unknown and feared other by societal and judicial means such as those epitomised in the apartheid regime. This attempt at exclusion is a denial of the inextricable bonds between self and other. Whether in union with the other, desiring that union, or denying it, the bond is irrefutable. The self requires reflection in the other in order to gain proof of its existence: acknowledgement by another grants and reinforces individual identity. Elisabeth, for example, undergoes a crisis of identity when she realises "there is no one in terms of whom she can be recognised" (49). In the wilderness, she is no longer a daughter, friend, wife or mother, but merely a woman without a defined role. In denying the other, the self denies crucial aspects of its own identity. This denial is usually framed in terms of justifications based on binary oppositions in which the other is deemed inferior in every category. Thus, the other may be black, female, homosexual, uneducated,

\footnotetext{
${ }^{46}$ Notably, the self/other union depicted here is a complication of two distinct binary pairs, that of the female/male and of the black/white. My discussion will focus predominately on the black/white pairing as representative of self/other politics.
} 
illiterate, impoverished and impure, in contrast to the more favourable binary values associated with the self: white, male, heterosexual, educated, literate, wealthy, pure.

The desire for community, for companionship and understanding, which each of the protagonists displays, reflects a desire to move beyond restrictive modes of contact and to explore the other. This desire has obvious significance in the context of segregational realms such as apartheid South Africa. If the other were truly 'undesirable' - as envisaged in apartheid ideology - there would be no need to regulate interracial interaction. Segregation is a regulation against a human instinct to commune. Ironically, the prohibition of such interaction deems it even more desirable. Adam's urge to follow the group of explorers and his ultimate decision to expose himself to Elisabeth and to join her is indicative of the desire for community which exclusion instigates (17ff): he initially follows the wagon "weighing his freedom against his loneliness" (73). His escape, framed in terms of self-exile, results in a desire to return to others, to explore relationships beyond the individual: his 'freedom', therefore, is not absolute. Adam is symbolic of the self/other paradox; the dual fears of entrapment in community and fear of exclusion.

Adam's motivation for following and approaching Elisabeth is a desire to learn of the Cape, to hear of all that he has abandoned in order to gain 'freedom' (34). As he stands before Elisabeth and allows himself to be noticed for the first time, he silently asserts, "[h]ere I am" (18), claiming identity and inviting acknowledgement. Her initial response, "[w]ho are you?" (18) reiterates the concern with identity expressed in the text's opening words. After Adam has stated his name, she repeats her question, demonstrating a resistance to the acknowledgement Adam desires. This resistance will, in due course, dissipate, as the relationship between self and other, male and female, mistress and slave, founded on the precepts of 'civilised' society, is reassessed and reconstructed in the relative 'freedom' of the wilderness. The desire for union, community, a cure for loneliness, impacts on the negotiated relationship between the pair. When Adam feels Elisabeth watching him, he believes her observation is founded on a desire for connection. He realises that all that is required 
of him is to look up and he will "see" her, but wonders what would he say?: "I know you? I don't know you? Who are you? What are you doing here? You don't belong here" (21). Echoing Elisabeth's initial question, the question of first contact, Adam also articulates the spectrum of interactions by which self and other may engage. Ranging from acceptance to denial, each of these engagements is enacted, at some point, in their relationship. Union with another is desirable, it appears, and yet also poses a threat to selfhood, representing as it does a surrender of the sovereignty of self. Echoing and foregrounding various power plays enacted between himself and Elisabeth, Adam wonders, "[w]ho [...] is in whose hands? Who needs whom?" (34). Individual survival, each of the protagonists (initially) suggests, depends on exclusion of the other and yet such exclusion results in individual isolation and loneliness.

The theme of abandonment is set in juxtaposition to that of union and each prompts consideration of the self/other dynamic. Elisabeth's fears of abandonment are most specifically imaged as a recurrent dream in which she is buried in a porcupine hole (129), a fear derived from the "Hottentots" method of abandoning ill and elderly members of the tribe who cannot keep pace with their fellow travellers. As their journey progresses, however, Elisabeth becomes less fearful for her own safety and more concerned for that of Adam (106-7). This shift in perspective traces a progression in their relationship, in which self-preservation is subsumed by a concern for the other. This shift has relevance beyond its location in the text. In its reflection on the self/other dynamic, it also points to interracial relations in South Africa; in each context, the fear of self-dissolution drives the exclusionary project of segregation. In the text, this fear is discarded in favour of concern for the other; thus, Adam asks, "[w] hat will become of us if we no longer hold onto each other?" (227). This recognition is an acceptance of the part the other plays in selfhood, as discussed above.

Ultimately, the self/other union is viewed as one of both liberation and bondage. Liberation derives from the complete realisation of selfhood, an acknowledgement of aspects of selfhood that are fully realised only in their reflection 
in the other. Ultimately, the text's central question, 'who are you?' is answered: Elisabeth claims, "[w]e are" (236). Drawing on the mythology of first contact between coloniser and colonised, a mythology inherent in the original Fraser narrative, Elisabeth and Adam's encounter re-envisages the development of black/white relations while simultaneously reflecting on their contemporary enactment. The narrative is thus an examination of both a developing 'civilization', in which possibilities are rife, and also of a contemporary society, burdened by centuries of segregation, oppression, violence and hatred. Thus, Elisabeth and Adam's first conversation, which commences with her question, "“[w] resonates in both historical and contemporary contexts. The question echoes throughout the text as a constant reminder of the interplay between self and other.

The pairing between Elisabeth and Adam evolves over the course of the text, undergoing many transitions in which the interaction is reassessed and/or renegotiated. Initially, Elisabeth is fearful of the 'threat' posed by Adam, the black/male/slave. She muses,

[y]ou, dark man, death or life: who and what are you? [....] Why do I fear you? [...] I'm afraid of you. All right, in this darkness I'm prepared to admit it. The only way to control you is to command you. Fear is more imperative than one's little dignity. But why should I fear you? [....] What is your place? Have you any place [...]?" (66)

Elisabeth articulates a series of issues which frame negotiations of identity between the pair. Firstly, she acknowledges her fear of the unknown identity before her and questions the basis of this feeling. Secondly, she acknowledges that oppression is used to quell this xenophobia. Thirdly, she voices a desire to identify Adam, to discover him as a person and to place him in her context. These articulations are the basis on which self/other negotiations begin.

In the text, power plays demonstrate the renegotiation of interpersonal relations between Elisabeth and Adam. Elisabeth attempts to assert her authority and to ensure some control, by means of her racial and class 'superiority'. Adam's lack 
of concern when Elisabeth accuses him first of murdering her husband and then of stealing his clothing, and his disrespectful response, prompt her to ask, "[w]ho do you think you are speaking to?" (19). Her attempt to assert authority over Adam is, however, a failure: he continues to resist. When Elisabeth asks, "[w]here do you come from?" (20), his vague gesture acts as an obstacle to her attempts at categorisation. He refuses to be 'understood', fearful that this knowledge will enable her mastery over him. This is the paradoxical fear of the self/other dialectic: one must relinquish some part of oneself to another in order to commune, or else remain isolated. Elisabeth recognises that a role reversal has taken place: "[i]t is as if he has taken over momentarily, a quiet supervising master" (44). She is now "powerless" (48), her "white vulnerability" (81) making her dependent on him for survival.

This dependency is problematic. While Adam is granted some sense of esteem in this role reversal, the relationship maintains binary dichotomies. The self/other relationship between mistress and slave is merely replaced by the male/female pairing first represented in Elisabeth's original dependence on her husband. Thus, there is no opportunity for equality in these terms. Adam recognises his own oppressive tendencies acknowledging "the need, the necessity, to remain in control. To subject her to his decisions. To keep her in her place" (83). Elisabeth attempts to assert her authority by ordering Adam to bring her water, relegating him to the slavery from which he has escaped. The ensuing exchange demonstrates Adam's recognition of the societal structures on which authority and oppression depend:

'In the Cape I would have had to obey you. Here it's up to me to decide.'

'In the Cape I would have forced you to obey me.'

'Oh no. The Cape would have forced me, not you. Otherwise you would have been able to do it here, too.' (76)

His acknowledgement that societal structure and expectation frames behaviour echoes throughout the text as a warning that the Cape and its inhabitants - symbolically, contemporary white South Africa - will not accept the relationship which develops between Elisabeth and Adam. The only possibility for its continuance is in an 
environment free of prejudicial political and social frameworks. The South African interior, therefore, represents the uncharted possibilities of new forms of social interaction such as that negotiated between Elisabeth and Adam, a metaphor which will be further discussed. Thus, for Adam and Elisabeth, the interior is their "little paradise" (145) in which they are 'freed' from the constraints imposed by an ostensibly 'civilised' society.

The journey into the self and towards the other is suggested in the physical journey into the South African interior. The map which Larsson carries on his trek contains a small portion inscribed with demarcations which represent the landmarks and contours of the land: this portion is "surrounded by white emptiness containing only a few tentative lines and dots, open and exposed, terra incognita, great and wide" (17). The terra incognita of the landscape is the unexplored and uncharted territory beyond the defining and delimiting boundaries of the segregational context of apartheid; it is, therefore, open to a myriad of possibilities. This is the landscape Elisabeth and Adam metaphorically traverse, moving away from (and yet ultimately returning to) the prescribed and charted territory of 'civilisation' in which relations between self and other are prescribed, defined, limited.

Each of the central characters undergoes a journey of self-discovery and investigates an alternative mode of interaction with the other, far removed from the prescriptive engagements allowed by 'civilised' society. Elisabeth muses, "what am I doing here? I must have come in search of something" (20). Throughout the text, there is conflict between two distinct forms of community and isolation. 'Civilisation' offers a multitude of relational ties, and yet there is isolation in the manner in which the gendered and racial other (Elisabeth and Adam respectively) are treated. In contrast, the wilderness offers an environment in which the union between Elisabeth and Adam is possible, and yet they are forever exiled from the community of their respective peoples: the only possible solution to this solitude is found in the creation of their own community, in the miscegenative offspring which they imagine 
(128). This conflict, in which the desire for togetherness is offset by both feelings of isolation and the desire for independence, frames the text.

\title{
Miscegenation
}

\author{
“"'They'll never forgive you,' he persisted relentlessly. \\ 'If their white women start doing this sort of thing: \\ it undermines everything in which they've got to believe \\ if they want to remain the masters in the land"
}

(Brink Instant 231).

Developing thematic links first introduced in The Ambassador and Looking on Darkness, the author portrays various sexual encounters in order to focus on the dynamics between self and other and, most specifically, to explore interrelations between traditionally segregated groups such as black and white South Africans. Some of Elizabeth's earliest childhood memories establish her sense of identity and her understanding of interpersonal relations in sexual terms. Specifically, the memory of her genitalia being furtively stroked by the brown hand of one of the slave children $(167-8,246)$ prefigures and frames later miscegenative acts, while the incestuous sexual abuse she experiences with her Uncle Jacobs (64, 237-8) foregrounds the sexual power plays of subsequent sexual interactions. The sexual relationship between Elisabeth and her husband Larsson may be viewed as a continuation of Elisabeth's formative sexual experiences, in its reflection on the interplay between the male self and the female other. The union is a disappointment to her: there is no connection between the pair, and their intercourse is merely a means by which roles of domination and submission are enacted (162). After their first coupling, Elisabeth expresses her disappointment and Larsson responds, "'I don't understand you"' (161), a summary of their relationship. Elisabeth's desire was "to know what it meant to be a woman, to be transformed into a person by [Larsson]" (61). She articulates her need to be recognised and acknowledged, the desire to be granted proof of one's existence through union with another. 
The threat of the sexual or gendered other is also examined in sexual terms in the text. Elisabeth represents "the ultimate thou-shalt-not, the most untouchable of all, [...] white, woman" (22): her role in ensuring the racial purity of future offspring is sexually defined. Until their (consensual) sexual union, Elisabeth's stance is that of the stereotypical Afrikaner woman resistant to the threat of interracial 'rape'. When she confronts Adam with her fears, he denies any attraction to her, prompting Elisabeth to suggest, "[w] hat we really fear, $[\ldots]$ is this space forcing us inward to one another" (89). Adam's conception of the sexual dynamic is revealed in his claim, "I can take your body and force it and break it, I can tear a scream from it: a scream of life like that other scream of death. But even so you'll be untouchable. Your eyes. Somewhere inside your body, beyond my reach, you have secured yourself in your whiteness" (54). Adam suggests that the self/other union must be consensual, one must give freely of oneself in order to completely unite with another. His claim raises the question, does this refusal to truly engage operate in reverse? Can blackness secure itself against complete invasion?

The relational interplay between Elisabeth and Adam is often described in terms of love. The manner in which love is depicted, as both a form of bondage and of control, represents the power struggle between self and other. It is this torturous co-dependency which prompts Adam to describe his love for Elisabeth as "agony and anguish" (171), as he recognises the responsibility and bondage of emotional attachment. The acknowledgement of emotional ties leaves one vulnerable to the other, susceptible to domination. Elisabeth's concern that togetherness subsumes individuality is prefigured before her marriage to Larsson. Reflecting on marrying Larsson and becoming "one flesh", she asks her father, "[w]hat will be left of myself?" (245). The model on which she bases her knowledge of matrimony, that of her parents, epitomises inequality, warning of the dangers of submission to another. Throughout the text, the battle between Elisabeth and Adam to retain individuality while finding solace in one another, continues to reflect this power play. 
It is this struggle between self and (gendered/racial) other which results in Adam's ultimate betrayal, a theme which permeates the text and adds further resonance to the exploration of interrelationships and their outcome. Textual evidence points to Brink's attempts to represent a model of 'first contact' that achieves two goals. The first is to demonstrate the possibility of non-exclusionary practice and to model the conditions under which this may have come about removal to the 'uncharted' interior, away from the mechanisms of social propriety. Simultaneously, his narrative is concerned with remaining true to history; he imagines the reasons why interracial union was never realised (at least not in a way that was ultimately represented in South Africa's socio-political structures). $\mathrm{He}$ considers how to model possibility while remaining true to historical outcome. $\mathrm{He}$ sets up the conditions under which the overlaid pre- and pro-scriptions of society may be dismantled while acknowledging that, ultimately, this possibility was not realised. Thus, interracial union remains a future possibility worthy of further exploration in subsequent texts.

\section{Dissidence}

"Can you understand what happens inside one when you grow up to discover you will never be allowed to be anything in your own right?"

(Brink Instant 150).

'Punishment' of the type experienced by both Elisabeth and Adam on their return to civilisation is instigated in response to a dissident stance foregrounded in the text in terms of both content and context. Each protagonist represents a dissident reaction to an oppressive environment. Adam - the racial other- escapes both literal and figurative bonds. He searches for freedom beyond the society that oppresses him and thus poses a threat to carefully policed categories such as self/other and civilised/uncivilised. ${ }^{47}$ Elisabeth symbolises the gendered other and epitomises,

\footnotetext{
${ }^{47}$ For an examination of the master/slave relationship, see discussion of $A$ Chain of Voices in Dixon, "Shouting against Silence: André Brink's Voices of Truth.".
} 
specifically, the situation of the white female, subordinate to the male, in Afrikaner society at the time: "[n]ever to be able to do what you really want, because you're a woman; never to be allowed to become what you desire, because you're a woman...." (65). Like Adam, she resists, reacting against the stultifying conventions of her society and refusing to behave in the manner expected of her. She is adamant that she will no longer allow herself to be subjected to such treatment: "I can't allow anyone else to dictate to me. I'm not just a woman, I'm a person. I want to mean something" (245). Further, she correlates gendered prejudice with racial forms: after confronting her father regarding his paternity of illegitimate slave children, she accuses him, "“[y]ou think a slave is nothing but a woman!"” (27). Thus, she articulates one of Brink's central concerns: the author recognises that the male/female dynamic rehearses power plays similar to those of the white/black dichotomy. This acknowledgement flavours the interaction between the protagonists in crucial ways. Their relationship rehearses renegotiations of power in various pairings - black/white, male/female, mistress/slave - simultaneously. Their respective positions as 'dissidents' add additional energy to this renegotiation, as each refuses to adopt a submissive position.

The dissident stance foregrounded in the content of the novel is also reflected contextually, reinforcing Brink's own challenging position. The novel includes reference to the manner in which civilisation is as imprisoning as slavery. Elisabeth claims that the authorities goveming South Africa would "like to keep us here, confined between the mountains and the sea. I suppose they're scared of what would happen if we started moving inland. They may lose some of their authority" (37). This statement speaks to the contextual environments of both South Africa at the time, and also the contemporary apartheid era in which the text was written and published. The metaphor is one of both literal and figurative confinement and control. Citizens are exposed to limited physical, social and ideological environments and denied alternatives. This restrictive situation has an obvious correlation with the apartheid era in which the actions of not merely the black inhabitants of the nation, but also their white counterparts, remained circumscribed by 
legal and social frameworks. Miscegenation, for example, was both socially unacceptable and punishable by law for both black and white South Africans. Further, Elisabeth's statement reinforces imagery in the text related to journeying "inland", or inward. The suggestion is that it is necessary to move beyond prescribed boundaries in both personal and social terms: a journey into one's self and towards the other. In discovering and exploring alternative physical, social and ideological environments, the authoritarian stranglehold may be loosened.

\section{Returning to 'Civilisation'}

"We have come such a long way on our trek through one another"

(Brink Instant 236).

The miscegenative coupling between Adam and Elisabeth is the central motif on which the text hinges, offering a response to the segregational context of both the novel's setting and the South African environment in which the text was published. The consummation of their relationship represents the rejection of imposed societal taboos and their acceptance of one another as individuals, beyond (forbidden) racial categories. Adam articulates this acceptance of the other when he says of Elisabeth, "I recognise you" (188). This union between self and other is a frequently articulated early postcolonial response to prejudice and to the antagonistic interracial relationships which ensue. Ostensibly, in accepting the other, selfhood is fulfilled and prejudice rendered obsolete. However, this 'resolution' to the prejudices involved in interpersonal and interracial engagement is problematic. Acceptance of another may be viewed as subsuming the other into the hegemony of the self. This act naively denies difference, collapsing all into a hegemony that does not allow any form of specificity: cultural, ethnic, linguistic and gendered specificity, for example, are masked by a focus on collective homogeneity. Brink's decision to portray the continuation of Elisabeth and Adam's miscegenative relationship as a failed enterprise may be viewed as indicative that the relationship itself is no resolution to interracial prejudice. Rather, the relationship is symbolic of each protagonist's 
individual journey of self-discovery in which traditional values are examined and renegotiated. The miscegenative relationship is therefore metaphorically relevant in its portrayal not merely of a journey towards the other, or into the self, but also as a reassessment of societal relationships per se. This journey is also undertaken by the author and the reader - each 'progresses' into the 'interior' - or psyche - in a manner similar to that of the protagonists.

The novel's focus on relations between self and other and their representation in miscegenative acts offers a specific challenge to prejudicial policies and practices. While the novel's historical setting is at a remove from contemporary events in apartheid South Africa, the text speaks metaphorically to that context and to the necessity for negotiations of identity between self and other, black and white. The ostensibly 'uncharted' territory of the South African interior which Elisabeth and Adam traverse becomes representative of the uncharted in terms of both personal and historical realms. The metaphor speaks to the uncharted territory of otherness and, implicitly, of selfhood. Central is the foregrounding of possibility, the challenge to the restrictive and the implicit suggestion that the reader participate in the critique of prejudicial frameworks and societal oppression, to question one's relationship to the other. Whether in specific contexts such as that of the apartheid regime or in more universal terms, the journey is relevant. Brink offers no simplistic solutions, no happy conclusion, but rather poses the questions necessary in such environments, and encourages each reader to involve her/himself in imagining a solution. As Adam states in the text, “[d]idn't you know that one asks most of one's questions only because one knows they cannot be answered?" (232). This statement may also describe Brink's position, a role instigated in texts such as The Ambassador and Looking on Darkness and continued throughout his oeuvre.

\section{A Dry White Season}

"another dry white season" 
(Brink Dry 163).

A Dry White Season represents a further landmark in Brink's social and political commitment, another 'rebirth' in which his engagement with South Africa is refocused and reinvigorated. The titular "dry white season" reflects the aridity and inhospitable nature of both the fictional heterocosm and of contemporary South Africa. The phrase derives from Mongane Wally Serote's poem, "For Don M. Banned", which describes a hiatus in the revolutionary movement as a dry white season, a period where nothing constructive nor destructive occurs (Sheckels 197). This bleakness frames the text, and is the motivating factor for the narrator's retelling of Ben's narrative. The unnamed narrator is a writer of romantic fiction, suffering from writer's block. He adopts images of aridity to describe this period of artistic muteness, in which he cannot speak to, or of, his environment (11). Disillusioned by the irrelevancy of the material which is the basis of his narratives and awaiting new inspiration, he brings together a miscellany of notes and records compiled by his deceased friend Ben, creating a narrative framework by which to piece them together. It is his role to imagine the gaps, and bring the narrative alive: "what is illegible or missing I must imagine. What he suggests I must expand" (33). He contextualises the 'facts' surrounding Ben's investigation and death, much as Brink himself imagines a fictional context for his political environment.

It is no coincidence that this text was the first Brink novel to be published after the Soweto Riots; this event demarcates a turning point in South Africa's political realm, and in Brink's response to it. The riots represent a moment in South African history when large numbers of the public began to openly challenge the apartheid state, and a time when this protest was met with unjustified and increasing violence, in a state clampdown on the masses intended to quell public dissent. The horrific events of 1976 prompted Brink to complete a manuscript he had earlier set aside. He notes 
Biko's back as it were, and use him to write a novel about a person dying when a real person - and such a person - had died so close to Grahamstown. In fact the whole thing started when the Security Police arrested him there. It was only after I lived through that whole traumatic thing that I realised that it was also a matter of making sure the people knew about it, and were forced never to allow themselves to forget it, because it's amazing how easily people can just wipe anything as dramatic as that off the slate. ("Interview by Jim Davidson" 27).

Clearly, Brink considers the completed novel a restorative project, a means by which to record the horrors of a specific oppressive environment. This intention is evident in the content of the text which directly engages with the realities of the apartheid years. Abandoning the metaphorical exploration of contemporary issues of $A n$ Instant in the Wind, Brink instead imagines a contemporary South African reality and speaks directly to it.

The text is steeped in political detail, describing the political realities of contemporary South Africa. The manner in which this novel speaks to a specifically political context is evident in the author's disclaimer:

Nothing in this novel has been invented, and the climate, history and circumstances from which it arises are those of South Africa today. But separate events and people have been recast in the context of a novel, in which they exist as fiction only. It is not the surface reality which is important but the patterns and relationships underneath that surface. (4)

A Dry White Season is, in one sense, a catalogue of horrors, an ongoing series of unjust and oppressive incidences narrated in a documentative style, from which the reader is neither shielded nor distanced. The novel resounds with corporal punishment (39), unjust imprisonment (51), beatings, ill-treatment, torture $(50-1,67)$ and death $(37,76)$. Most specifically, the Soweto riots provide a violent background to the text's central events $(37,41)$ demonstrating Brink's imaginative engagement with the specific political realities of his era. The author does not, however, limit his treatment to an overview of the apartheid regime, a tract in which oppressor is 
contrasted with victim; individual, everyday cases of oppression and brutality are also imagined. Stanley, for example, speaks against those who have oppressed him, complaining that every aspect of his life is delimited by white authority (98), his complaints pointing to specific apartheid legislation. In this way, this text enlarges Brink's implicitly humanitarian and dissident stance to a contestation against specific prejudicial treatments of black South Africans. By individualising state oppression, the text highlights aspects of the apartheid regime which had remained long unspoken and encourages the reader to empathise with individual characters suffering hardships under oppressive legislation and policing.

Likewise, the author frankly describes the tone of the era, encapsulating the mistrust and fear of both black and white. Those in authority are particularly prone to prejudicial statements of this kind. Mr Cloete, principal at the school where Ben teaches, symbolises conventional Afrikaner mistrust of the black other. His claim that "[y]ou can't trust one of them these days" (54) is reiterated by Afrikaners throughout the text. Further, justificatory statements are made for the mistreatment of blacks, such as those made by Captain Stolz of the Special Branch of the Police: "[l]ook at everything the Government's doing for them - and all they can think of in return is to burn down and destroy whatever they lay their hands on. [.... No white child would behave like that" (62). The black view of the white man is similarly mistrustful and accusatory. Stanley has learnt from experience to mistrust (white) authority noting that "when a man gets picked up by the Special Branch, you just start talking about him in the past tense, that's all" (54).

The text, like an Instant in the Wind, revolves around a central question, rephrased and readdressed throughout. Initially, Gordon, who seeks his missing son, poses the question. When he is informed of his son's death in police custody, he asks, "How did Jonathan die?" (48). When news of Gordon's own death reaches his wife, Emily, she, in turn, adopts the stance of inquisitor, asking, "Why did they kill him?" (92). Recurring throughout the novel, questions such as these become the motivating force for Ben's investigation. His inquiry is essentially a questioning, of 
himself and of others. Searching for the truth on behalf of others, he also discovers truths about himself. Confronted with the injustice and oppression of the apartheid state, he is prompted to consider his own complicity in that context. Simultaneously, he feels increasingly alienated from his own environment, indeed, from Afrikanerdom itself. Immersing himself in the milieu of the other, he discovers the humanity and witnesses the pain and suffering of the black South Africans of his community. He is horrified. His inquisition is both a literal and metaphorical examination of the central tenets on which his life as an Afrikaner is founded. In his questioning of the police and of the courts, each of which exemplifies injustice, Ben challenges the authority on which his ideological beliefs depend; the investigation is both outward and inward, critiquing prejudicial environments, but also one's own complicity in them. Increasingly, he symbolises a dissident response to the alienation, oppression and injustice surrounding the other. This response is a central concern. The reader's increasing awareness of, and horror at, the violence and corruption of the apartheid state parallels that of Ben. In this sense, the reader is encouraged to participate in the act of investigation which frames the text. Here, Brink's ongoing 'cultural conversation' is framed as a mandate to challenge oneself and one's environment. It is an imperative to question that which has traditionally been taken for granted. 


\section{Investigating Otherness}

"The Government is handling the electorate as if it were a bloody donkey.

Carrot in front and kick in the backside.

The carrot is Apartheid, Dogma, the Great Abstraction.

The kick is, quite simply, fear.

Black Peril, Red Peril, whatever name you want to give it"

$$
\text { (Brink Dry 187-8). }
$$

The investigation which Ben undertakes represents the type of challenge proposed by the author. Ben moves beyond the known boundaries of his environment, both literal and figurative, in order to engage with other realities. His association with both Gordon and Stanley enables this investigation of self and other. His developing friendships with these men parallel his increasing awareness of the injustices the other suffers in a prejudicial and oppressive environment. His journey towards the other represents a journey into the unknown, a connection between two separate realities: "[n]ever before had he experienced so acutely the total isolation of their respective worlds, and the fact that only through the two of them those worlds were allowed to touch briefly and provisionally" (171). As he comes to recognise and acknowledge the individual humanity of the racial other through these relationships, he feels alienated from the physical and ideological frameworks on which his life has depended. Returning home, he realises

all at once this was what seemed foreign to him: not what he'd seen in the course of the long bewildering afternoon, but this. His garden, with the sprinkler on the lawn. His house, with white walls, and orange tiled roof, and windows, and rounded stoep. His wife appearing in the front door. As if he'd never seen it before in his life. (99)

In this respect, the text is a further exploration of the self/other dialectic examined in An Instant in the Wind. Here, the comradeship represented in Ben's interactions with Gordon and Stanley is used in a similar way to that of the sexual interaction depicted 
in the earlier text. Each speaks to the segregation of self and other in an apartheid context and offers opportunity to explore the possibilities of union.

A Dry White Season depicts contemporary oppression of the other, while simultaneously critiquing the basis on which the prejudicial regime relies. The author considers the relationships of power and control constructed in the name of apartheid. He depicts the collective oppression of the masses, and also describes individual cases of injustice and mistreatment. His critique is, therefore, both a critique of the 'apartheid regime' over the masses, and of one's personal relationships with the other; it is both collective and individual. In the context of the novel, the oppression of the other is ostensibly legitimised under the name of apartheid. However, the oppression is merely a modernised addenda to any other form of historical enslavement. This enslavement is depicted as a response to the threat of the other; ostensibly a method of controlling fear. As Professor Bruwer articulates, every man is on his own; each has to find his own definitions, and each man's freedom threatens that of all the others. In both this text and An Instant in the Wind, the journey towards otherness results in the destruction of either the self or the other. Brink proposes black/white union as an ideal while simultaneously describing its tragic results in the context of a hostile regime. In this respect, he remains true to both contemporary and historical contexts which deny such union. Ultimately, A Dry White Season depicts the journey from self to other as one of self-discovery, in which traditional values are examined and renegotiated. As in An Instant in the Wind, it is the reassessment and re-negotiation of societal relationships, which results from the self/other union, which is crucial. In each of the novels discussed here, the individual - rather than society undergoes transformation. 


\title{
Narrative as a (Dissident) Record
}

\author{
"in a certain sense a writer is 'selected' by his subject \\ - his subject being the consciousness of his own era.
}

How he deals with this is, to me, the fundament of commitment"

(Gordimer "Selecting" 116-7).

The desire and hope for societal change is, however, constant; narrative is apparently the means by which the possibilities of change may be imagined and rehearsed. Responding to his own question as to what he can possibly hope to achieve, Ben foregrounds the act of narration highlighted in the text, suggesting that narration is in itself a redemptive act. This claim mirrors Brink's own statements concerning the redemptive role of narrative. Speaking specifically of the South African context, he argues that "where the word has become employed more and more to distort and to destroy, I am committed to the faith that only the word can be used to correct and to create" ("Arts" 57). In the novel, Ben reiterates the importance of his particular narrative, stating, "'I've got to be sure that someone will look after it. That someone knows about it"' (13). It is my contention that this objective to record is shared by Brink himself. The novel stands as an account of the apartheid years, an exposition which testifies to the experiences of those who suffered and those who witnessed that suffering. It is a challenge to all to acknowledge the prejudicial and oppressive nature of the apartheid regime. It is in this context that Brink's text is most specifically a reaction to his political environment and representative of a further development in his oeuvre. Brink abandons the 'indirect' approach adopted in response to censorial impediments and returns, with renewed vigour, to directly confront the prejudicial policies and practices of the apartheid regime. Specifically, he uses narrative to both record and challenge the mistreatment of black South Africans. This text depicts Brink's increasingly blatant description of, and engagement with, the specific social and political environments of apartheid South Africa. This particular 'rebirth' develops from both the censorial environment in which Looking on Darkness was banned, and the political environment in which the 
Soweto Riots occurred. In response to both the censors and the authorities, Brink claims, through his protagonist, "that it will not be possible for any man ever to say again: I knew nothing about it" (316). The reader is denied the terrible excuse of Nuremburg and is forced to confront her/his own complicity in interracial prejudices. A Dry White Season, I have argued, is a refutation of the power of the censor, an indictment of the apartheid authorities and also a challenge to complicit individuals. ${ }^{48}$

\section{Conclusion: The Dissenting Voice}

"There are only two kinds of madness one should guard against [....]

One is the belief that we can do everything.

The other is the belief that we can do nothing"

(Brink Dry 244).

Brink's 'cultural conversation' continues in both An Instant in the Wind and A Dry White Season. The themes addressed are essentially those of his earlier novels: the prejudices and oppressions of the apartheid regime are scrutinised and undermined. I have argued that An Instant in the Wind develops Brink's use of miscegenation, introduced in Looking on Darkness, as a metaphor for interracial relations. As an adjunct to that discussion, I briefly discussed Brink's next novel, $A$ Dry White Season, as a further example of Brink's exploration of interracial concerns in the context of platonic relationships. I have focussed, therefore, on each text's concern with black/white interaction, a pivotal theme in the context of apartheid South Africa, in which racial segregation is fundamental. In this respect, these novels challenge prejudicial practice, suggesting that connection with another is both a fundamentally human instinct and one which counters the inhumanity of apartheid. Gerise Herndon claims that "[p]olitical works attempt to redefine the social order"

\footnotetext{
${ }^{48}$ In a way fittingly, the text was itself censored, subject to a ban enacted in September 1979 (Cope 136). Brink claims established South African publishing firms were intimidated by the censorial milieu and refused to publish the text and it was therefore released by Saayman and Weber and published in London in the same year (Cope 136). Brink did not submit the novel for examination by the censors, but instead sent copies of the text to subscribers (Ilan Peleg 131). The film version of the text, released in 1989 under the same title, was subsequently banned.
} 
(237); this pair of texts attempt this type of redefinition. Brink's focus on interracial relations and his imperative to journey towards the other in order to examine selfhood/interior/psyche place these texts as political. While the themes of the novels are developments of those of earlier texts, the framing and focus of the novels is reconceptualised as a direct response to the environment in which Brink writes. In these terms, the novels are shaped by their contextual environment. I argued that the deployment of an historical metaphor in An Instant in the Wind was a direct response to the censorial environment in which Brink's previous publication, Kennis van die Aand Looking on Darkness was banned. I discussed the manner in which this metaphor operates, and made claims regarding its effect as an 'indirect' examination of prejudicial themes. A Dry White Season, in comparison, represents a direct, explicit engagement with the horrors of apartheid South Africa in the mid-1970s. Brink's specific and detailed descriptions of the injustices and oppressions of that era provide a documentary record. I suggested that Brink's return to the direct engagement with the political realities of his nation was instigated by two central events: the Soweto Riots and the banning of his previous novel were motivating factors. I argued that this reinvigorated and refocused commitment to write in a directly dissident manner is a further development in his work, another 'rebirth'. A Dry White Season, I claimed, is a testimony, (an attempt at) a redemptive act in which the protagonist, the narrator, (and, implicitly, the author) each claim the right to speak of their realities, and to record them. The novel is, therefore, a challenge, posed by the author, to both the authorities and his society. His implicit imperative is for others to speak of their experiences, to challenge the censorial and authoritative versions by which the world is traditionally narrated. Brink's mandate is essentially that of Camus, whom Professor Bruwer quotes in the novel: "[o]ne always has a choice" (190). The choice is between acceptance, or challenge: Brink chooses to challenge.

In each text, the promise of interracial union is ultimately quashed by the reigning authorities. I have argued that this bleak tone suggests that any hope of reconciliation is a future, rather than a present, possibility. However, the deferral of 
interracial resolution and the end of segregation does not obviate the need for present action. As is demonstrated in later texts, the oeuvre becomes increasingly concerned with the necessity for present action in order to facilitate this imagined nonprejudicial future. Each of the texts under discussion is framed by a question - one that is rephrased throughout the novel. Within these questions, I suggest, lies the key to each. They speak not merely to the text's central themes, but also outline the direction Brink himself, as author, follows. In each of the novels thus far, Brink does not reveal a simplistic resolution, but rather poses questions. Elsewhere, Brink notes that this is the function of the dissenting author: s/he "is not a provider of ready answers, but an asker of questions" ("Writing Against Silence" 206). "Only through questions", Brink argues, "can one hope to gain access to truth" ("Arts" 58). Throughout his oeuvre Brink continues to ask and rephrase his questions, to examine their contours and imagine possible answers. 


\section{CHAPTER 4}

Exile and the Exilic Position:

The Coloured Perspective in

The Wall of the Plague

"An island between two existences"

(Brink Wall 81). 
The black/white dichotomy which ostensibly typifies racial issues in South Africa is inevitably too simplistic a model to explore the intricacies of racial engagement and politics in the nation; it denies the positions of those deemed beyond the categories of either black or white. Central to both Brink's exploration of the South African context and my commentary on it is a shared awareness of the situation of those for whom both 'black' and 'white' are alienating - arguably exilic - terms. Statistical data of the South African population points to a multitude of ethnic groups, many of whom are not represented by the terms 'black' or 'white'. The majority of these South Africans are encompassed under the collective term, 'coloured'. 49 This chapter will examine the position of 'colouredness' and consider the implications of the state of double marginalisation - or 'in-between-ness' - which the term implies.

Historically, practical difficulties in racial differentiation have led to the deployment of visual markers as determining factors, eliding questions of genetics in relation to outward appearance. This reliance on the visual is suggested in the terms by which race is often described: descriptors such as black, white and coloured putatively indicate various hues of skin tone and thus verbalise the primary physical characteristic by which race is conventionally differentiated. What is clear, however, is that differentiation on the basis of skin tone is merely a pretext which (ineffectually) masks more insidious motives; racial classification is more closely aligned with political and ideological objectives than with scientific claims or rationale - skin colour is merely a means by which to demarcate groups of privilege from the oppressed.

Seemingly unperturbed by the difficulties associated with determining race, the apartheid regime legislated to reify racial theory as fact, creating categories ostensibly racially-based. In 1950, The Population Registration Act 30 divided the population into three distinct categories, white, coloured and native (later renamed

\footnotetext{
49 As Paton notes, many 'coloured' South Africans refuse the term, preferring instead to label themselves 'black', 'so-called coloured' or 'classified coloured' (20-1). While recognising the problematic nature of any racial term (except, arguably, those adopted by the racial groups
} 
Bantu and still later black) (Ormond 21). ${ }^{50}$ A system of classification was deemed necessary and justifiable in terms of the rhetorical, imaginative and administrative purposes of the state. Apartheid legislation was premised on - indeed depended on racial categorisation, a system assumed to be meaningful. For black and white South Africans, the effect of such legislation was to enforce segregation. In terms of the authorities, the legislation ostensibly ensured reliable demarcation from an administrative point of view and provided a legislative basis by which prejudicial treatment was effected. This allowed for the maintenance of privilege and power for the white group and a concomitant disempowerment of black South Africans.

Apartheid legislation also had the adverse effect of encouraging the maintenance of that same racial binary for those who would challenge the oppressive regime: whites came to represent 'the oppressor' and blacks 'the oppressed' in revolutionary struggles. Thus, regardless of one's acceptance of 'race' as a meaningful method of classification, apartheid remains a defining feature, even if one resists racism. An awareness of this distinction between the rhetoric of race and the physical characteristics and realities of a diverse population is central to an understanding of the implications of racial policy in South Africa. Apartheid policy and, in particular, the segregational intent of such policy, is premised on racial beliefs without scientific endorsement or a rational basis. The groups into which the South African population is divided may be viewed as constructed categories vulnerable to deconstruction. In this respect, the revolutionary struggle is not one of 'colour' black versus white, with a problematic third category of coloured - but rather one of the oppressed versus the oppressor.

The existence of this third category in an otherwise black/white binary is of particular interest in the South African context; discussion surrounding the coloured

themselves), for the sake of clarity and consistency, I will refer to this disparate 'group' as 'coloured', with apologies.

50 'Coloured' and 'native' South Africans "could also be subdivided according to their ethnological groups" (Ormond 21). Section 5 (2) of Proclamation 46 of 1959 divided coloureds into Cape Coloured, Cape Malay, Griqua, Indian, 'other Asiatic' and 'other Coloured' (Dugard 60-1). A series 
position provides a useful platform from which to challenge prejudicial policies. On the one hand, 'coloured' is a designated category into which those people who are deemed neither black nor white can be contained (physically, given the aims of the morality laws). The descriptor commonly refers to the miscegenative offspring of black and white South Africans; descendants of a variety of groups including slaves from Malaya, white settlers and sailors, the Khoikhoi people and various indigenous tribes (Paton 20-1) are defined by the collective term. These various peoples are homogenised under a referent which depicts them solely in terms of their mixed racial ancestry and elides any distinct ethnic affiliations. In this respect, the coloured category may be viewed as an attempt to prevent (further) dilution of 'pure' races simplified as black and white. However, the term encompasses 'other' racial groups as well as those classified as of mixed blood. Asiatic South Africans, for example, may be as racially distinct and 'pure', in terms of their ancestry, as Afrikaner or British South Africans, and yet they are incorporated into a composite group 'coloured'. Effectively, the category is an amalgamation of the racially distinct and indistinct. This racial commingling operates counter to the proclaimed intent of racial classification, the segregation of the various races. Reputedly, categories of race are designed to circumvene an admixture of this kind. Thus, the classification of 'coloured' operates against the rhetoric surrounding the maintenance of racial 'purity' - rhetoric which putatively justifies and maintains apartheid ideology. The problematic nature of this miscellaneous category 'coloured', points to fundamental inconsistencies in both the system of racial classification and the rhetoric of race which supports it. The miscellaneous nature of the grouping suggests the arbitrariness of the entire system and reveals the manner in which racial categorisation is a social and political construct designed to support the state's prejudicial policies; an awareness and critique of this aspect of apartheid ideology permeates Brink's work.

of subsequent re-negotiations of racial classifications points to problems of definition and highlights the homogenising nature of such terms. 
For coloured South Africans, the challenge is to find a way to live that is not constrained by the limitations of a particular racial grouping. The political landscape, however, is configured in such a way as to demand (racial) alignments (for reasons of force and power). Seemingly, the coloured subject must choose a racial - inevitably also political - affiliation in order to survive in such an environment. The choice available to members of the coloured group becomes one of pragmatically accepting an alliance with another racial group. This momentary 'acceptance' of racial groupings is at a purely rhetorical level and is not an endorsement of the system of racial categorisation per se. The coloured subject struggles to retain a sense of selfhood in a situation which disallows any meaningful communal identity groupings or terms (other than those that conspire to make one feel doubly marginalised in one's own place). The coloured South African is doubly dispossessed, marginalised from both white and black communities. This marginalisation leads to feelings of rejection and displacement, feelings which have many similarities with those experienced by exiles.

\title{
Exile
}

\author{
"Displacement is an exile \\ from older certitudes of meaning and selfhood"
}

(Krupnick 109).

In one of Brink's later novels, An Act of Terror, Thomas asks, "Surely one can be an exile only abroad, in some foreign land? Or is another kind of exile conceivable, inside the place you love?" (159). I have intimated that the experience of the various marginalised - and of the coloured in particular - may be likened to that of the exile; the sense of estrangement of the physical exile is shared by those denied a sense of belonging. Effectively, a sense of estrangement is not merely common to all exiles, but is a defining characteristic of exclusionary practice. Like the racially marginalised, female subjects in a patriarchal society are effectively exiled from the possibility of acceptance and equal treatment they imagine in a fair 
society. Arguably, women experience the same feelings of rejection, subsequent rootlessness and longing for return as those associated with actual exile. A feminist awareness of the unnatural and illegitimate nature of patriarchy and of the unjust position in which women exist is recognition of the manner in which they are exiled from the privileges which other - (white) male - members of society enjoy. Similarly, black South Africans experience an exilic state in that they are also denied access to certain fundamental rights and privileges and long for a new order. Again, the longed for (imagined) and just society represents a loss of what should have been, rather than the physical removal conventionally referred to as the exilic process. In each case, the basis of this denial is a socially and politically constructed system of control which ensures that 'undesirable' subjects remain excluded. In this respect, exile is a fitting metaphor for the sense of loss and desire experienced by those rejected and/or denied. What is unique to coloured South Africans, however, is that the experience of exile is doubled, representing exclusion from both white and black communities. Arguably, under apartheid, coloured South Africans are forcibly denied identification with both whiteness and blackness and instead occupy positions of 'in-betweenness', 51 enforced and undesirable states of isolation likened to exile. For female coloured South Africans, the layers of marginalisation, of exclusion, are further multiplied.

In counterpoint to this notion of exilic or excluded subjects is the premise that a sense of belonging is an ideal and desirable state. Throughout Brink's oeuvre, individual and collective identity and identification are central concerns. As I have suggested in earlier chapters, in Brink's texts one's sense of belonging in terms of both place and community is considered central to an understanding of selfhood. In a nation in which so large a degree of one's impulse towards identification is determined and/or constrained by the tenets of the state, the church and the community, perhaps a certain rootlessness and desire for union beyond these strictures is inevitable. In this respect, every South African may identify with the

\footnotetext{
${ }^{51}$ Thus, Trui, a coloured woman who appears in Brink's Imaginings of Sand, describes herself and her ethnic group as "us in-between people" (169).
} 
exilic aspects of experience and empathise with the doubly marginalised position of the coloured.

\section{The Wall of the Plague}

\section{"And South Africa, a volcano smouldering through it all to remind one of the persistence of the Black Death"}

(Brink Wall 441).

The Wall of the Plague (1984) treats the problematic positioning of coloured South Africans. First published in 1984, the novel traces the parallel literal and figurative journeys of Andrea Malgas, a coloured South African expatriate from District Six. Andrea's literal journey is a research trip across Europe taken in order to identify possible locations for a film project she and her white lover, and writer, Paul, are working on. Her figurative journey is twofold. Firstly, it is a journey across a land whose history reflects the ostracism of the apartheid era in South Africa: the titular wall of the plague, constructed in the $14^{\text {th }}$ century in order to exclude those infected with the Black Death, provides an analogy for the contemporary prejudicial (mis)treatment and exclusion of non-white South Africans. Secondly, Andrea's journey is also an inner one, an "appointment with [her]self" (85). Before she left for Provence, her lover, Paul, proposed to her and this trip reputedly grants her the freedom to reflect on that proposal and to make a decision. Her response to Paul's question is crucial. If she were to accept, the interracial marriage would exile them both irrevocably from her homeland as their marriage would be considered illegal in apartheid South Africa. Despite her self imposed (and self-proclaimed) exile from South Africa and her lack of desire to return, their marriage would enforce permanent exile and the loss of the choice to return if she so wished; ${ }^{52}$ she must decide either to renounce her ties to South Africa irrevocably, to continue to live as a rootless individual, or to return to her homeland.

\footnotetext{
${ }^{52}$ Consideration as to whether chosen exile constitutes a truly exilic experience is discussed in chapter one.
} 
Ultimately, she accepts that she is both coloured and, inevitably, South African. This renewed awareness instigates a (solo) return to her homeland to adopt a dissident stance against the apartheid government. In the terms described above, her self-examining narrative echoes that of Martin in Rumours of Rain and prefigures that of Estienne in On the Contrary. However, Andrea's narrative is significant in that her perspective is that of a coloured woman - her viewpoint is thus doubly removed from the traditional white male perspective represented by the narratives of Martin and Estienne. Her narrative is, therefore, central to Brink's ongoing examination of the South African environment in that she represents the marginalised positions of both females and coloureds. In examining each of these positions, the text interrogates the inevitability of the subjection or oppression of females in a patriarchal milieu and of coloured subjects in apartheid South Africa. ${ }^{53}$

The text is also a return to earlier themes. In its concern with miscegenation and the enforcement of the Immorality Act, the novel echoes Looking on Darkness and yet the focus is not on the discovery of the miscegenative act, or on the punishment Andrea and her white lover receive, but on the consequences. After their discovery (144), both Andrea and her former lover, Brian, are charged under the Immorality Act and are subsequently granted suspended sentences subject to their agreement to leave the country (260). Andrea's memories of the miscegenative relationship and its horrific outcome constantly resurface, in memory and discussion, providing a contextual backdrop to her contemporary relationships, in terms of both social and political contexts. Recent and historical past events are thus used, as in other Brink texts, to reflect on the contemporary context and to consider future possibilities.

\footnotetext{
${ }^{53}$ I will consider the female position more fully in chapter ten.
} 


\section{The Plague}

"the invisible Plague" of apartheid"

(Brink Wall 385).

The most significant historical event which operates in the text in this way is the bubonic plague, pandemic throughout Europe and parts of Asia during the $14^{\text {th }}$ century and reported to have decimated three quarters of the population over a period of two decades (Microsoft). ${ }^{54}$ Brink's text is permeated with references to the disease and the novel's very structure is determined by the fact that victims die within five days of infection: Brink's novel is therefore partitioned into five parts which trace the five days of Andrea's joumey, a progression towards a figurative re-birth. Historically, the Black Death provides material for a number of literary examinations which reflect on the social and moral implications of exclusionary practice. Albert Camus' La Peste (The Plague) (1947) is the urtext to which Brink's later examination speaks. Camus' parable examines human nature, aligning the physical manifestation of plague symptoms with a metaphorical plague affecting humankind. The text suggests that every individual is in some way affected by this figurative plague, either by infection, complicity or in active resistance to it. The novel's implicit commentary on the German occupation of France and its effects prefigures Brink's use of the analogy to reflect the apartheid context. In each of the novels, there is a mandate to grapple with the problems of one's age. This urge towards moral imperatives is evident in the epigraph to Brink's text, borrowed from one of Camus' characters, Tarrou: "All I maintain is that on this earth there are pestilences and there are victims, and it's up to us, as far as possible, not to join forces with the pestilences" (207 qtd. in Wall 7). In terms of both content and social commentary, therefore, Brink's text is aligned with that of Camus and yet, in each, the plague is not the central focus but rather a secondary narrative used to emphasise the novel's central concerns.

\footnotetext{
${ }^{54}$ Paul claims between one-third and half of the inhabitants of Europe died within a period of a few years. As is implied in Brink's novel, the plague is not merely historically significant, but remains a contemporary concern. The disease remains prevalent in some parts of the world and as recently as
} 
In Brink's text, various intertextual references to the 'Black Death', its effects and (ineffective) treatment, emphasise the experiences of Andrea and the context of apartheid South Africa. Notably, two organs are particularly susceptible to the symptoms of the plague, Artaud suggests: "the lungs and the brain, the only two organs that can be directly controlled by will and consciousness" (236) are the sites where the plague is manifested. The allegorical implication is that prejudice may purposefully be rejected. Further, excerpts from, inter alia, Daniel Defoe's A Journal of the Plague Year (1722) provide examples of the manner in which Brink's text is intertwined with the narrative experiences of an earlier age. The implication in linking the historical with the contemporary is twofold. Firstly, it is implied that history is cyclical - society repeats the events of the past. Secondly, the possibility of learning moral and practical lessons from the 'errors' of the past is suggested. This possibility is paradoxically countered by the first implication, that history is (deterministically) repetitive. This depiction of the problematic nature of the relationship between the past and present implies similar difficulties in extrapolating future possibilities from present events. Any suggestion as to a way forward must be judged in this context. 'Solutions' to contemporary social and political problems offered in the text may be viewed as suggestive and provisional. As in Brink's previous texts, The Wall of the Plague trials some possible solutions to the specific problems of apartheid South Africa, but offers no flawless model.

\section{Exclusionary 'Walls'}

"They keep us out of sight, because they're scared of us" (Brink Wall 284).

In the context of apartheid South Africa, the wall of the plague is metaphorically aligned with the exclusion of non-white South Africans and the

1994 an outbreak occurred in India; Paul asserts "there are still only five or six areas in the world from which the Plague regularly starts all over again - and [...] one of them is in South Africa" (39). 
sequestration of ostensibly threatened Afrikaners. In Europe during the plague years, fear of infection resulted in a decision to construct an extensive wall in an attempt to physically exclude those who posed a threat to the health of a town's inhabitants - the physical manifestation of a siege mentality. Paul recounts that the original Dutch settlers of South Africa attempted to create a similar protective wall against the dangers of the continent (56-7) and thus links the exclusionary practices of $14^{\text {th }}$ century Europe to those of $17^{\text {th }}$ century South Africa and, metaphorically, to the apartheid era. He claims, "That's the worst of the Plague [...] that one tries to deny what one doesn't know. That what you know nothing about you cannot accept as true" (292). In both contemporary and historical contexts, social interaction in South Africa has been predicated on exclusionary practice. In various models of oppressive practice - from the historical oppression of slave by master, to contemporary economic and governance imbalances between black and white - prejudicial treatment is founded on the privilege of one group and the exclusion of another. Thus, the wall represents the various forms of exclusion in practice in apartheid South Africa, the legislated and social forms of the exclusive versus the excluded. Notably, just as the wall is a constructed edifice, so too are the labels by which exclusion and exclusivity are defined and maintained. What is suggested, in the exposure of such construction, is that the labels are, like the wall, vulnerable to both decay and destruction. The means by which this destruction may occur, however, is imperfectly realised in this novel.

While plague allegory represents acts of exclusion, the fear of 'infection' provides scope to examine the fears which motivate exclusionary practice. Blackness is an ostensible 'plague'. Both the wall of the plague and apartheid are constructed in attempts to prevent the spread of infection, the taint of blackness. The contagious nature of the plague victims is aligned with the assumed infection of 'blackness'. This analogy is particularly apt given the symptoms of the disease which include the appearance of black spots on the skin, hence the term 'Black Death'. Each of the undesirable characteristics associated with a 'black' racial categorisation is viewed as a threat to the purity of whiteness. The white community, reliant on myths of purity, 
morality, intellectual acuity and spiritual enlightenment, associates the negative, opposing characteristics with blackness (Mohamed 63). Thus, in order to avoid the contamination of impurity, immorality, imbecility and paganism, members of the white group must construct and maintain a barrier. ${ }^{55}$ In terms of apartheid South Africa, this barrier is a network of legislated and social frameworks which ensure the exclusion of blackness. Whether in the context of Europe during the plague years, or in the colonial years of South Africa, or in apartheid South Africa, the implementation and retention of exclusionary frameworks is a result of the fear of 'infection'. The text's focus on isolation and exclusion, the fear of infection and the impossibility of determining the infected reflect similar motivations and practices in terms of apartheid South Africa.

Notably, each of these constructions - the wall and apartheid legislation fails to protect against contagion. As Paul suggests, these forms of protection merely bring about another disease. Speaking of the plague years he notes,

The way it warped and distorted the brain, the emotions, one's whole dignity. Making one suspicious towards all other people, even those nearest to one, those one is supposed to love, because their very closeness poses the greatest threat. In the end nothing is too revolting or excessive to consider. The imagination grows weary. One learns not to care. Total indifference settles in. Everything around one is black and transparent with death. And right through the lovely smell of rosemary one recognizes the Plague itself, for everything is infested with it. (41)

Despite attempts to eliminate the risk of infection the 'protected' are overcome by paranoia and general malaise. Like the characters of Camus' La Peste, Brink's characters are effectively contaminated with a separate affliction, one that attends the first but is physiologically distinct. In these terms, apartheid is actually the more virulent disease which infects society. It represents the contamination to which

${ }^{55}$ For a complete historical examination of the inception, maintenance and operation of stereotypes, including discussion related to the 'otherness' of both blackness and illness, see Sander L. Gilman's Difference and Pathology: Stereotypes of Sexuality, Race, and Madness. He notes that "Writers, both 
Coetzee refers when he discusses Brink's conception of the artist as diagnostician of the diseased state ("André Brink and the Censor" 61ff).

\section{The Coloured Position}

'I've spent my whole life 'in between', not really belonging anywhere [...]

- neither black nor white, but 'coloured', whatever that may mean'

(Brink Wall 335).

The plague analogy, representing the segregation of black from white, problematises the coloured position. The impossibility of determining the healthy from the infected suggests that the division of black versus white and their associated (stereotyped) characteristics is similarly impossible: as Paul imagines, "'How shall I recognize the Plague when I see it? How do I recognize a Jew? What does a heretic look like?'" (40). Further, historical attempts to counter the risk of infection, most notably exemplified in the wall, fail. Paul muses, "It's easy to be amused by it afterwards; to say they should have known better: how could the Black Death be stopped by a manmade wall? What hurts, is not the comment it offers on the dead but on the living" (439). The text suggests that apartheid is similarly flawed in its attempts to separate the 'healthy' from the contaminated; it fails to represent those for whom the labels of healthy/ill or white/black are inadequate descriptors. One must ask if the wall metaphor is to be utilised in respect to the coloured South African populace, where does the coloured subject reside? Must s/he inevitably reside with the blacks/ill, on the outside of the wall, in order to ensure the continued health/whiteness of those within, or must a third space be designated? In this context, the coloured position represents a 'grey' area of categorisation between healthy and ill, black and white - a position denied in the apartheid context where division was clearly established between white and non-white.

liberal and conservative, employed the image of the black as a reflex of difference in their texts. Political ideology can thus be formed by stereotypes as much as it forms them" (127). 
This grey area of racial categorisation is a central concern in Brink's text, reflecting the problematic double marginalisation of coloured South Africans. A newspaper report Paul shows to Andrea demonstrates the impossibility and futility of attempts at racial categorisation and characterises the coloured position as an indistinct space between black and white. The item reports the discovery of an abandoned baby girl whose future will be determined by means of racial classification. The article notes that "scientific methods" have been used to determine the coloured status of the child. These methods comprise "an examination of a single hair, which was found to be crinkly" (94). Thus, Andrea is prompted to consider whether her own future children will be relegated to "a twilight world of half-people, neither white not [sic] black" (94), wondering where she 'belongs', with which group she should be aligned. This is the central question which frames colouredness, both in the text and in the apartheid model. The reader is also encouraged - by means of an empathetic relationship with both Andrea and the abandoned child - to consider the issue of racial inclusion and exclusion, a theme pivotal to both Andrea's individual examination of selfhood and her sense of collective belonging. Should she, as her brother Boetie and Mandla suggest, join the black revolutionaries who struggle for equal rights? Alternatively, should she align herself with the 'white' world, represented by the men with whom she has been romantically involved? Mandla derisively labels her a "try-for-White" (111); Expressing his disgust at her racial 'treachery', he implies that her relationships with white men reflect her refusal to confront her 'colour'. In aligning herself with the 'whiteness' of her romantic partners, he claims, she avoids the responsibilities of her 'colour', refusing to challenge the prejudicial treatment of both black and coloured. 


\section{Longing for Identification}

"even now no more than a guest, a traveller, an adopted child, in transit"

(Brink Wall 272).

Andrea's search for identification and belonging is enacted in her various relationships with men, but is also indicated by her suppressed longing for South Africa. Despite the racial discrimination and associated injustices of Andrea's birthplace, the temptation to return to South Africa remains. She and the various expatriates who roam the fictional heterocosm are connected by their love/hate relationship with the land they have abandoned or been exiled from, each desiring the beauty and comfort of 'home' while rejecting the political and social injustices which characterise it. Paul claims, "I'd drawn my comfort, however meagre, from knowing that I'd left the country, that I was no longer there. Surely that, too, was a way of withholding my consent?" (435). He claims that his self-exile is a passive form of protest against the nation's prejudicial policies and yet, ultimately, his exilic state is viewed as an avoidance of his responsibilities as a white South African. Like Andrea, in a state of exile, Paul avoids any direct confrontation with the realities of the political situation of his homeland. The focus of his research avoids his contemporary context in terms of both history and geography. He is thus both a literal and metaphoric exile, estranged from the context he critiques in his work. Like Paul, Andrea experiences a constant conflict, longing for her 'home' while simultaneously repelled by the impracticalities of living in such an environment (160). However much she denies her longing for home, her feelings of angst symbolise those of any exile, caught between two places - the land from which one is exiled and one's chosen residence: each land offers only part of the imagined paradisiacal homeland.

In this text, physical exile parallels the psychological exilic aspect of Andrea's experience, reinforcing the notion of the exclusion of coloured South Africans. Images of exclusion depict the exilic condition as experienced both within and 
beyond South Africa. For Andrea, her original homeland becomes a symbolic "longlost land" (27), a forbidden paradise in many respects, forbidden not because she cannot return, but because she (initially) considers the prohibitions associated with her return untenable. She epitomises the position of exiles in both literal and metaphorical terms. Under apartheid, as a coloured South African, she is excluded from both black and white communities; as a woman, she is marginalised in a patriarchal society; and as an expatriate she is physically exiled from her homeland. She complains, "I'm a woman. I'm coloured. I'm everything that can be exploited" (73). Throughout the novel, Boetie, the initial political voice in the novel, articulates the marginal position of the coloured community. He claims, "in this country you got Black and you got White. But what about us? What's 'Coloured'? It's nothing, it's neither Black nor White, just in-between sort of, and they're squeezing us from both sides" (64). Some of the novel's central questions revolve around the sense of belonging posited in the notion of 'home'. Where and what is home? $(237,270)$. As in earlier Brink texts, each of the central characters undertakes a (sometimes unconscious) search for roots, for a location in which to centre one's identity, "A place to weigh anchor" (300). Inevitably, for exiles, the location and substance of home remains problematic and unresolved. For coloured South Africans, one's homeland is a nation in which senses of communal identity and belonging are denied.

The sense of rootlessness associated with exile is evident. While skindiving in tidal pools in South Africa, Andrea metaphorically describes two aspects of her exilic experience. As she comes out of the water, she notes,

Re-emerging, inevitably, at last, one stumbles clumsily over rocks and pebbles. All of a sudden one no longer feels at ease in what has always been one's 'own' world. For a long time one will carry behind one's eyes the imprint of other realities, other dreams. One's feet will now feel ill-equipped to find their way, sounds will be different, harsher, more ominous. One feels driven by a dark urge always to stumble back to that submarine world so briefly glimpsed, so deeply lived. And yet, at the same time, one knows that permanent return is impossible: one can never live there. However magical it 
is, one can never be more than a visitor, an on-looker, an in-looker, an intruder in the other world. One remains conditioned by the requirements of lungs, the need for air. In there, one will always be a stranger, will never 'belong'. A brief, beautiful immersion - then the sad return, back to this side, to the place one has come from. Even if one knows one will, in future, never quite belong here either. (23)

The world beneath the water represents "a world operating according to laws different from those in one's own" (23), a realm of possibilities disallowed in apartheid South Africa. The underwater world is akin to being abroad, a place where Andrea does not belong, but in which she is paradoxically allowed freedom of movement. In contrast, when she returns to the land, she is newly aware of the manner in which her movement there is constrained. During this figurative return to South Africa Andrea's sense of belonging is thrown into question and yet she acknowledges that she is inextricably tied to her homeland. Despite her acknowledgement of the manner in which she naturally belongs in South Africa, she also realises that she will inevitably remain an 'outsider' in both worlds - an acknowledgement of dual aspects of the exilic experience. Andrea's 'colour' determines the manner in which she is treated both in South Africa and, as is demonstrated in the text, by the racially prejudiced of Europe. She has not, therefore, discarded prejudice in deciding to leave South Africa, but rather exchanged the overtly and institutionally legitimated/enforced discriminatory practices of apartheid South Africa for less overt and less frequent instances of racism and moralistic prejudice in Europe. ${ }^{56}$ Discrimination, it appears, is more widespread than the apartheid regime. As Boetie foresees, the issues by which she is defined in South Africa follow her into exile (261). It is suggested that figurative exile - a sense of dispossession - is the condition of coloured South Africans both within and beyond South Africa. Exilic images of this sort continue in the text as Andrea comes to realise her alienation from Europe, her chosen place of exile, and is drawn back to South Africa. 
Andrea's decision to return to South Africa and her resolution to join the black resistance movement and become actively involved in challenging apartheid practice are posited as the solution to the exilic aspect of coloured experience. In terms of the plague wall imagery which frames the text, Andrea chooses to join those who refuse to accept the wall as a valid and impermeable structure; instead, they endeavour to scale its walls and demolish it piece by piece. ${ }^{57}$ Andrea's alignment with black resistance is a strategic one, a means by which she may, communally, protest against the unjust treatment of not merely black, but also coloured South Africans. In direct confrontation with the injustices of the apartheid regime, Andrea may assert her identity as a member of South African society, as a woman and as a coloured. In confronting the specific prejudices by which she is oppressed, she hopes to establish both a more just society and also assert her identity and value. The hope for future change in the apartheid state and in the treatment of non-white South Africans is seemingly the motivation which drives Andrea to return. Focussing on Mandla's involvement in black activism, she resolves to continue his struggle for black rights. There is little acknowledgement, however, that contemporary South Africa remains unchanged and that she will return to a nation 'plagued' with the same prejudices and oppressive policies as when she was exiled. Seemingly, the events which instigated her withdrawal from her homeland are no longer valid reasons to remain in exile. ${ }^{58}$ The problematic nature of her return is thus avoided in the text. As in previous novels, the specific and practical details of any solution to apartheid South Africa's problems are deferred to a future date. Brink's text instead suggests a possibility for resolution, often avoiding or ignoring the complications by which this possibility may fail and focussing predominantly on the elements by which it may succeed. Andrea's return to South Africa, it is implied, is merely an initial step in an ongoing, personal challenge to the prejudicial milieu of apartheid South Africa. The

\footnotetext{
${ }^{56}$ Examples of discrimination extend beyond the racial. In Avignon, Brian and Andrea are refused accommodation because they are not married (130-1), an ironic counterpoint to the 'immorality' of their relationship in the South African context.

57 This call to action against an oppressor pre-empts Brink's later interrogation of the validity of specifically violent protest in An Act of Terror.
} 
means by which this challenge may be launched are secondary to the acceptance of responsibility and will to action Andrea exemplifies.

\title{
Countering Marginalisation
}

\author{
'What's in a name?' \\ (Shakespeare Romeo and Juliet 52).
}

In response to the marginalised position associated with her femaleness and her colour - marginalisation which positions her effectively as a non-person - Andrea attempts to create an identity for herself beyond such delimiting categories. Her selfconstructed identity is premised on a number of inversions of prejudicial and/or oppressive societal practices. First, declarations of one's existence permeate the text, emphasising the desire to assert one's place in an environment which denies such identification. As Andrea is being examined by a surgeon to assert whether she has breached the Immorality Act, she notices some graffiti carved into the wall of her cell. The phrase, "I was here" - a statement which operates as proof of existence, an assertion of identity - is juxtaposed with the inhumane treatment Andrea experiences, in which she is objectified, denied the rights of (white) humanity (265). The incident echoes others in which she inscribes her name on various edifices in order to assert her identity in specific spatial and temporal contexts (197, 372-3). According to the narrator, the graffiti fulfils a desire "To be present wherever one finds oneself: with the full weight of one's whole history, one's whole self, all one's possibilities" (394). The desire to claim a sense of belonging, to assert one's existence in a certain temporal and spatial environment, is an important precursor to Andrea's ultimate assertion of identity, her decision to join the struggle for black rights and oppose the inhumanity by which black and coloured South Africans are labelled.

\footnotetext{
${ }^{58}$ Presumably, and problematically, the circumstances in which she was initially exiled will no longer apply, as she has distanced herself from her white lover.
} 
Andrea's second inversion of prejudicial practice is related to the act of naming. This act may be viewed as a mini-narrative of identity, a label by which one's place in society is identified. Names may also be considered markers of the roles of oppression and submission in which the power to name is associated with ownership - the namer and named are forever bound by this relationship. ${ }^{59}$ As outlined in the preceding chapter, in postcolonial terms, naming asserts authority over the named, whether in relation to the land, its vegetation or its inhabitants. In societal terms, the familial tie is traditionally represented by the father's surname, the patronymic (and, in the case of the - usually male - first-born, often his full name) being conferred on his children. Female children may later exchange this surname for that of their husband, while male children continue to impose the patronymic on future generations in a continuation of patriarchal labelling. Clearly, in terms of female subjects in particular, this practice denies individual markers of identity independent to male lineage. Further, any name conferred by another may be viewed as an imposition, in which the named subject has no right, (and often no ability), to protest against such naming. In these terms, the sense of ownership associated with being named by another is countered by the possibility of naming oneself, an act which ostensibly asserts one's freedom. Andrea's assertion or reclamation of personal, individual identity is centred on her use of the term "Nanna" to describe herself. A remnant of her childhood, when she was unable to pronounce "Andrea", the nickname persists as an assertion of selfhood beyond the labelling of others. Further, the name is also invoked to describe anything claimed as her own; a rag doll, a stray kitten and her favourite blanket, a present from her father which she carries with her on all of her travels, are each granted the name of "Nanna" $(65,345)$.

However, while this inversion of the naming process allows Andrea some control over her own labelling, suggesting a reversal of the power play in operation, it is also problematic. Firstly, she is still, inevitably labelled, and is therefore still determined by a set of characteristics associated with that label. Despite her

\footnotetext{
${ }^{59}$ For further commentary in this regard, see the chapter entitled "Who are you?: The Search for Truth in A Chain of Voices" in Dixon's Shouting Against Silence: André Brink's Voices of Truth.
} 
(admittedly inadvertent) construction of the term, and the sense of 'control' which the power to name implies, the label remains restrictive. Secondly, in naming herself and, more specifically, in naming those objects which she owns, she perpetuates through merely inverting - the naming/ownership process against which she rebels. She thus represents the inextricable position in which one's identity is linked to a limiting mode of representation, that of language, and to the constructive processes by which prejudicial terms are designated and maintained. Andrea's failure to recognise her own imperialist attitude in this respect is emphasised by her continued awareness of and complaints about her own marginal and oppressed position.

Andrea's experience of rootlessness and her crisis of identity are also countered to some degree - and somewhat ironically - by an invented relationship and ongoing dialogue with an imagined ancestor named Xhorê (133). Brian quips that she may be able to trace her ancestry back to Xhorê, a member of the Khoikhoi who travelled from the Cape to England aboard an English ship. He spent six months in London where he was treated as a pet, but pined for his homeland so desperately that he was eventually returned to the Cape. However, he continued to be dissatisfied, longing for London and unable to reconcile the two distinctly separate experiences until, as Andrea relates, "He didn't seem to belong anywhere anymore" (134). Eventually the English returned to the Cape and a dispute resulted in Xhorê being sentenced to hanging. Andrea clearly identifies with the estrangement epitomised in the figure of Xhorê and Brian's narrative inspires her to communicate with her 'adopted' ancestor. This ongoing exchange provides Andrea with an ancestral and historical base of identification. Traditionally, an ancestral link symbolises one's belonging in an historical and familial context and, in these terms, Andrea's assumed relationship with Xhorê is arguably redemptive in that it operates in opposition to the exclusion by which coloured South Africans are demarcated. However, the importance of this association is not premised on an ancestral link Andrea need not revert to imagined kinship for such identification - but rather with her empathy for a similarly rootless figure. Like Andrea, Xhôre is caught between 
two poles, and it is to this doubly exilic state that she relates - it is with rootlessness she identifies, rather than with belonging. ${ }^{60}$

\title{
The Dissident Stance: Action as Proof of Existence
}

\author{
"“Imagine going on and on like that, \\ against all the power of kings and cardinals and armies.' \\ "That's exactly what makes one go on."'
}

(Brink Wall 266).

Throughout the text, the double marginalisation Andrea experiences provides opportunity to reflect on the problems of the exilic state both in and beyond South Africa and to postulate a solution. The journeys framing the text culminate in a complete reassessment of Andrea's life. She describes "The slow loosening from my grip of everything I'd always thought of as ordered and manageable and mine: the new perspective on what I'd used to regard as too obvious for enquiry" (380). Further, she asks, "Can what you relinquish open you up to the possibility either of something new or something already forgotten?" (381). The solution to rootlessness is found in Andrea's decision to return to South Africa and to adopt an actively dissident stance against marginalisation, aligning herself with the black resistance movement. Notably, she tells Mandla, "I'm the same colour as you are. [...] I never knew it. For years I never wanted to know. I'm no longer living 'in between', Mandla. I'm no longer in a no man's land" (352). Here blackness is posited as "something already forgotten" (381), an essential characteristic long denied and recently rediscovered. However, her kinship with Mandla (like that with Xhorê) is not premised on a conventional understanding of the term 'colour', - specifically 'black' - but instead recognises the shared history of oppression and injustice which 'blackness' symbolises. This shared experience of prejudicial treatment and the

\footnotetext{
${ }^{60}$ Her relationship with Xhôre is also ironic in that Andrea again claims her own identity by association with others: again, this association is with a male subject. However, notably, this particular male subject is unable to oppress her: as narrator of his story, Andrea holds a position of authority over the deceased Xhôre, who is unable to retort.
} 
subsequent desire to challenge such oppression draws Mandla and Andrea together. The resultant sense of community, of belonging, is the panacea to Andrea's isolated and rootless existence. Andrea's sense of identification with Mandla's oppressed position prompts her to return to South Africa and join the 'quest' to challenge the prejudicial structures and practices of apartheid. This decision acknowledges that the political and social environment must be altered in order for marginalised South Africans to gain a sense of belonging, "a way of taking up a responsibility [she's] long tried to deny (399). It is the acceptance of one's moral obligation to act against immorality, as posed by Camus' text, La Peste. In terms of Brink's text, the 'immorality' of the present age is an inversion of the reputed immorality of miscegenation as posited by the state, and instead describes the prejudicial and unjust treatment of non-white South Africans.

Like apartheid, the plague is viewed as instigating similar rebelliousness. According to Paul's research, there is evidence to suggest a correlation between the plague and the subsequent "great social revolution of the same century" (323). The implication of Paul's insight is in accordance with Foucault's maxim that power - in this case specifically oppressive power - produces its own subversion (Discipline and Punish 223). In the text, one of Paul's sources, Ada Levett, claims, "The Black Death did not, in any strictly economic sense, cause the Peasants' Revolt or the break-down of villeinage, but it gave birth, in many cases, to a smouldering feeling of discontent, an inarticulate desire for change, which found its outlet in the rising of 1381" (Levett and Ballard n. pag. qtd. 323). So too, with the plague's metaphorical counterpart, apartheid South Africa: Andrea makes a decision to challenge the status quo, to take the opportunity to effect future change, as a result of her feelings of discontent under the conditions of apartheid. The acceptance of coloured South Africans, it is suggested - as with the acceptance of black South Africans - lies in the future and necessitates contemporary action. This activity - the actions of the marginalised, rebellious groups of South Africa - is a means by which the victims of a prejudicial political regime may assert their identities and allegiances. The apartheid state's denial of the rights of both black and coloured South Africans is 
challenged by an assertion of the value of black and coloured identity. An incident in which Andrea describes her shadow provides a fitting metaphor for this awakening and assertion of one's substantiality: "The strange discovery: I have a shadow! It's mine, exclusively mine. I claim it. Look at me standing here, being here. I have substance enough to block out the sun and cast a shadow. My own" (268-9).

\section{The Right to Choose}

Andrea: "I'm neither black nor white."

Mandla: "Right, so you're in between. It means you got to choose."

(Brink Wall 223).

As Mandla attempts to instill in Andrea a concern for the plight of her homeland, he states, "You got a choice!" (154). Ultimately, the only means by which Andrea may assume an identity of her own and create a place for herself beyond the marginalised position of colouredness is in asserting her right to choose. Amongst the choices available to her is the opportunity to make the moral, politically motivated decision to assume the struggle for a non-discriminatory nation. In making this choice, she is arguably asserting her identity in terms described by Franz Fanon. He suggests that the ability to choose is empowering; 'choice' determines one's humanity, allowing the assertion of not merely identity, but also of action (155). In these terms, Andrea's empowerment lies not merely in the act of challenging her oppressors, but also in her choice to do so: both choice and act represent the assertion of her humanity. ${ }^{61}$ Ostensibly, she creates an identity for herself as a South African when she adopts a dissident stance. In this respect, she is no longer merely coloured - with all of the prejudicial connotations which that term implies - but is instead South African.

\footnotetext{
${ }^{61}$ In Imaginings of Sand, the narrator asserts "there is a difference between taking a decision because it is the only one, and doing it because you would have chosen it from any number of others had they been available" (349).
} 
In the terms detailed above, The Wall of the Plague continues the cultural dialogue begun in Brink's earlier novels, extending the examination of the South African environment beyond that of black versus white. The coloured position is employed as a means by which to complicate and undermine the dichotomous presuppositions of the prejudicial apartheid regime. It is also a means by which to examine the exilic experience of those excluded from this oppositional model, and a forum in which to explore possibilities for identifying and maintaining identities beyond the confines of state segregational policy. I have suggested that much of the text is an exposure of the complex position of the coloured South African. This text is clearly a further step in a developing philosophy concerned with the problems and possible solutions of apartheid South Africa, a step in which depictions of, and possibilities for, the South African context are further developed. 


\section{CHAPTER 5}

\section{Looking Within:}

Afrikanerdom \& White Guilt in

The Ambassador, On the Contrary and Rumours of Rain

"Where does guilt begin

and with whom?"

(Brink Chain 393). 
Historical examinations of his nation are pivotal to Brink's examination of contemporary issues: he searches for answers to the problems of the present by delving into those of the past. It is important, in the context of Brink's work as a whole, to examine his depiction of Afrikaner complicity and guilt, as it is the issue which frames his own (dissident) position in South African society. In Brink's texts, examination of the confessional model in a South African context also raises questions as to the (white) writer's role as 'confessant', her/his role as spokesperson for a guilt-burdened community. ${ }^{62}$ Brink appears to speak on behalf of 'his people', suggesting the guilt of a community, while simultaneously implying that a large number of Afrikaners continue to deny their complicity in the injustices and oppressions of the apartheid regime. Brink represents, it seems, a rogue orator, rather than an 'authorised' spokesperson for 'his people': one must ask, is it possible to condone the actions of the individual (now seditious) Afrikaner while continuing to censure the actions of her/his group? This is one of many questions raised in examinations of this kind, questions which Brink raises in his work on this subject, even if he doesn't find answers.

The Afrikaner focus in the texts under discussion here also provides balance, in my exploration of his work, to discussion related to black, coloured and female South Africans. Thus, my examination is shaped by Brink's concern to explore the South African environment from a variety of perspectives. In this chapter, my examination of On the Contrary (1993) and Rumours of Rain (1978) considers the guilt of the white South African from dual perspectives - the differing viewpoints suggested by the texts themselves - and reflects on these issues as they were first raised in The Ambassador. In discussion of On the Contrary, I will briefly consider the historical sense of guilt experienced by the narrator in $18^{\text {th }}$ century colonial South Africa. This sketch of historical, colonial guilt will then provide a benchmark by which the contemporary experience, found in Rumours of Rain, may be compared.

\footnotetext{
${ }^{62}$ Kossew notes her interest in the emergence of Brink's "assertion of mea culpa and this reexamination of the very idea of writing both as confession and as resistance" at a time "when the role of white writers would be likely to be scrutinised carefully in the light of changing political realities" ("Anxiety of Authorship" 76).
} 


\section{Sin, Guilt, Confession \& Forgiveness}

"This terrible, primitive need to confess!"

(Brink Ambassador 197).

As I have suggested, The Ambassador introduces a series of themes which continue to permeate the remainder of Brink's oeuvre: the cycle of guilt and confession is central. In terms of this confessional 'system', characters are entrapped in a cycle of transgression, confession and forgiveness which structures their lives and permeates the very architecture of the novel. Each of the narratives are confessional, pairing various characters together as confessant and priest, and ultimately placing the reader in a role of judgement. Both personal and political responsibility are framed in terms of religious and ritualistic processes of sin, guilt, confession and forgiveness. In each confession, it appears the sense of guilt is assuaged by the confessional act: communality offers some relief from the existential angst of the individual, a realisation which is further developed in later texts. In a spiritual universe, a higher being offers absolution upon confession: in an existential universe, however, there is no absolution, and yet the characters enact the ritual, endeavouring to grasp an inaccessible peace. In these terms, sin and guilt are envisaged as the ultimate delimiters of freedom, as the removal of authority, (the deity), results in a residual guilt which can never be assuaged. If guilt is dependent on the possible redemption or forgiveness of an authority, then the removal of such authority ostensibly creates freedom from guilt.

These issues are relevant not merely at the level of the individual, but resonate in a national context. They bear relevance to debates surrounding national guilt as experienced in, inter alia, authoritarian regimes, in nations dealing with the consequences of colonial encounters and in those which have initiated truth and reconciliation commissions to explore past injustices. This spiritual angst links to similar concerns in a South A frican context. The loss of authority and of the security 
which that authority provides reflects the South African context in terms of both religion and politics. The dismantling, or opening up, of previously accepted forms of belief such as the Calvinist religion or the apartheid regime arguably creates an existential void in which there is no framework on which to base one's actions. The rituals of the church, however, remain: in a passage excised from the revised edition, the Ambassador laments, "[i]f only one could get rid of this concept of sin and live freely, live absolutely, without the relativeness of the system in which we are entrenched" (162). Thus, sin and guilt are envisaged as the ultimate delimiters of freedom: individual actions are circumscribed by the strictures of the institution, restrictions resisted by both protagonist and author. Ultimately, one must ask who defines "such cliches as 'sin' and 'guilt"? (187). Similarly, it must be asked, who can grant forgiveness, and where does grace lie? These questions are continually rephrased and addressed throughout the remainder of Brink's oeuvre. In terms similar to those used to question religious strictures, Brink's later work addresses issues of hegemony and blind adherence to authoritarian principles.

\section{On the Contrary}

"You think one man can cancel the accumulated guilt of a generation?"

(Brink Contrary 355).

Published just one year prior to the dismantling of the apartheid regime, On the Contrary examines roles of oppression in eighteenth century South Africa while simultaneously reflecting on the contemporary, disintegrating, apartheid regime. Clearly, events of the last years of apartheid rule prompted reconsideration of the role of white South Africans in the nation from both white and black perspectives. The likelihood of future 'black rule', in particular, instigated re-examinations of the historical, contemporary and future positions of both white and black South Africans. The text is also a rendition of the historical guilt associated with white oppressors what may be termed 'white guilt'. 
The protagonist, Estienne, is reputedly insane. He is visited by, and has conversations with, the deceased Jeanne d'Arc and becomes increasingly immersed in an imaginary world in which dreams, nightmares and visions merge. His 'madness' is, however, largely symbolic. Over the course of the novel, the reader is increasingly alerted to the manner in which Estienne's insanity reflects those who willingly transgress the boundaries of society. Because he is considered a "rebel" and a "traitor" (3) to that which has framed him, he must be excluded, an exclusion framed in terms of a dichotomy which opposes the sane and the insane. ${ }^{63}$ As Foucault notes, "The madman, understood not as one who is sick but as an established and maintained deviant, as an indispensable cultural function, has become, in Western experience, the man of primitive experiences. [He] is the man who is alienated in analogy. He is the disordered player of the Same and the Other" ("Don Quixote" 120). As I noted in the previous chapter in discussion surrounding selfhood versus otherness, the undesirable characteristics of madness - the lack of control and potential loss of power associated with loss of reason - are imposed on the other. ${ }^{64}$ In Brink's text, Estienne symbolises the marginal position of the dissident, the man who shouts the titular "on the contrary" in the face of authority. Over the course of the novel, he becomes increasingly resistant to the prescriptions of authority, rebelling against those who attempt to command him, while simultaneously realising his own authoritative and oppressive role. In these terms, the novel is an historical version of the same growth process outlined earlier in A Dry White Season.

On the Contrary traces the protagonist's increasing white guilt, an acceptance of responsibility and the exhibition of contrition. Arguably, taking responsibility for one's actions is the first step towards forgiveness, representing a counter to prior denial. Simultaneously, the adoption of responsibility is viewed as the creation of an ongoing commitment which potentially entraps: responsibility continues beyond

\footnotetext{
${ }^{63}$ This exclusion of the insane is interesting in light of Brink's conception of the apartheid state as diseased and of the artist as its diagnostician: his metaphorical interrogation of the state is an inversion of the traditional labelling of the diseased and/or insane other/transgressor.

${ }^{64}$ Dissident artists are positioned in similar terms. Likening the contestational stance of the author to that of the insane, Gilman notes, "Unlike the patient, of course, artists must create for themselves the
} 
oppression. Estienne refers to the time when he assisted Rosette's escape from slavery, noting, "That night I removed the shackle from your leg I did not realise it meant assuming for myself a burden for the rest of my life: my responsibility to you, to all those who remain shackled. I bow to that knowledge now" (371) and claims, "my own freedom had become involved with yours" (71). Estienne's acknowledgement of his complicity centres on recurrent memories of his involvement in the slaughter of indigenous tribes and he remains haunted by images of the murdered (358). As the novel concludes, Estienne also concludes his assessment of his complicity and guilt: he assumes the blame, shame and guilt of white South Africans (355).

In the traditional religious cycle of transgression, confession, penitence and absolution - as found in The Ambassador - Estienne's narrative is ultimately offered as a confession to the tribes harassed and abused during his time in the interior. The plot is structured around three journeys undertaken by the protagonist. The first is an exploratory expedition into the interior on behalf of his employer, the Dutch East India Company, the second, a trek to discover the fabled city of gold, Monomotapa and the third, an imaginative flight in search of the 'real' Africa, symbolised by a slave woman named Rosette. These journeys signal the three central phases of colonial history as identified by Luc Renders. He suggests the first episode represents the rule of a colonial power, the second relates to the era of gradual colonisation of the interior and the subjugation of the indigenous peoples, and the third symbolises a period of attempted atonement (11), the confession and plea for forgiveness with which this chapter is concerned. As Estienne's confession concludes, he humbles himself before those he formerly ridiculed: "To all of them I kneel and ask forgiveness; I wash and kiss their feet" (358). Many of the tribal members offer forgiveness, while others enact retribution. Estienne accepts punishment as willingly as he accepts forgiveness, claiming, "it is the only way to redeem myself. [....] It is a terrible via dolorosa, yet I exult. This is my necessary

persona of an outsider, which they don like a helmet to do battle with society" (230). Interestingly, Estienne fulfils both roles: he is both 'madman' and dissident author. 
purging on behalf of all of us who have invaded this space to subjugate it with our presumption and visit it with our devastation" (359). A physical purgation accompanies this metaphorical release, as Estienne refuses food, water, sleep (355) or clothing (361). Estienne suggests that complete atonement necessitates a rejection of all tokens of prior complicity and privilege, including - ultimately - his life. However, this purification process, in which his confession is met with both punishment and forgiveness, is merely imaginary: the tribal members who visit him are hallucinations. The narrator's various confessions are, therefore, essentially psychological self-confessions, a process of self-scrutiny and self-discovery in which he is the arbiter. In these terms, Estienne's narrative fulfils the requirements of the confessional form as defined by J. M. Coetzee: he engages with the problems of truth and of self-knowledge (Attwell 252). Simultaneously, the reader is privy to Estienne's confessions and is placed in the role of priest or confessor, with the associated possibility of offering absolution. Each of these relationships between Estienne and his various confessors is a further enactment of the possibilities of a confessional model, representing trials of the confessional process: in each, however, the granting of forgiveness is suspect.

The possibility of forgiveness suggested in the novel is crucial. Throughout Brink's oeuvre there is an inextricable link between past events and those of the future: he suggests that past injustices must be resolved (as much as that is possible) in order to create a future beyond the hatred and bitterness which has resulted:

'Forgive me,' I say to them. I prostrate myself in the dust before them and clutch their gnarled feet and say, 'Forgive me.'

'There is no forgiveness to be asked,' says an old man. 'Why do you want it?'

'Because I am here,' I say. "Because you are here.'

'You need nothing from us.'

'We need everything from each other. I was present at too many killings. Without forgiveness it cannot end.' (352) 
The narrator craves forgiveness not merely for his involvement in brutality, however, but also for his past inaction:

They have sentenced me to death for what I have done. I now accept that sentence for what I have not done, for what I have failed to do. Even if no one knows it. I know my true guilt, I acknowledge it. I assume it. And in writing it here today [...] I must try to ensure that my confession reaches others beyond you. (370-1)

In this way, he articulates the central anxiety surrounding Afrikaners in the apartheid state: Estienne highlights the co-agency of A frikaners who initially choose to remain silent and are, therefore, complicit oppressors, while simultaneously foregrounding a now dissident stance. In these terms, Afrikaners are denied a justificatory stance and are forced to assume the blame associated with inaction. Estienne's experience suggests that, while confession allows forgiveness, a sense of guilt remains. During his confession Jeanne tells him, "We have to learn, I suppose, not only to accept judgement or forgiveness from others, but to forgive ourselves" $(362)::^{65}$ the manner in which this may be done, however, remains unclear.

Ultimately, neither confession nor forgiveness 'save' Estienne or grant him grace. He is 'sacrificed' for his rebellion against the authorities, an execution which symbolises both the policing of accepted oppressive boundaries and also the existentially catastrophic consequences of a loss of belief in, or rebellion against, authority. Estienne is cleansed of sin, through his act of confession and atonement, but is punished by the state. In these terms, he negotiates the (imagined) reconciliatory process between himself as oppressor and those he considers his victims, but is unsuccessful in terms of the 'real' world, failing to favourably negotiate with those who oppress him. Is this an encoded suggestion that it is only from a position of power that one can safely negotiate? Is this why Brink considers it necessary for Afrikaners to instigate reconciliation? Clearly, the act of confession is the responsibility of those accused of wrongdoing and yet, in circumstances where the 
accused are unwilling or unable to confess, the reconciliatory process must inevitably halt, or perhaps even collapse. In light of Estienne's execution, the tone of the novel is consequently bleak suggesting that, despite Estienne's enthusiastic involvement in the confessional process, for him, reconciliation is a failure in any practical terms and his white guilt remains. ${ }^{66}$ His symbolic madness, the madness of dissidents, is a threat to authority and he must be exterminated. If Estienne and his journey into madness represent a failed (historical) attempt to reconcile, then perhaps the possibility of forgiveness and atonement lies in a contemporary context. Rumours of Rain is the text in which this hypothesis is tested.

\title{
Rumours of Rain
}

\author{
"in a land where rain was no more than a rumour \\ or an intimation of mortality" \\ (Brink Rumours 161).
}

Rumours of Rain explores issues similar to those later re-examined in On the Contrary, but in a specifically contemporary context. ${ }^{67}$ The text falls, chronologically, between those discussed in the previous chapter, An Instant in the Wind and A Dry White Season. While the historical setting of An Instant in the Wind places it at a remove from the two later texts, each shares a thematic concern with Afrikaners in South Africa, from varying viewpoints. A Dry White Season and Rumours of Rain frame this examination in a contemporary context and describe the 'awakening' of two Afrikaners who, for Brink, represent an imagined, collective set of 'Afrikaner' qualities. In the character of Ben du Toit, this awakening is a recognition and an acknowledgement of the injustices and oppressions of apartheid society. It is also an adoption of responsibility framed by a desire to both investigate

\footnotetext{
${ }^{65}$ Ironically, this is Estienne's own belief, as Jeanne, his constant companion, is merely a mirage, his voice who guides his conscience. Thus, his comment reinforces the notion that his confession is a selfconfession, with no one but himself to offer absolution.

${ }^{66}$ Estienne's guilt is clearly aligned with his position as a white man in colonial South Africa, rather than as an Afrikaner: as I have noted, he is of French descent.
} 
and 'correct' injustice and oppression. In Rumours of Rain, the awakening is framed in terms of an altered perspective in which both historical and contemporary denials and justifications of the imagined Afrikaner are viewed in a new light. The protagonist is forced to reassess his life and his identity as an Afrikaner and, in doing so, is also forced to come to terms with his complicity and guilt as a member of a privileged and oppressive group. The text is, therefore, not merely an examination of the guilt of a contemporary Afrikaner, but also an exposition of his initial denial of that guilt, and a tracing of his journey towards acceptance. Thus, through the individual awakenings of two representative Afrikaner characters, Brink examines the complicity, the responsibility and the guilt of Afrikanerdom.

Rumours of Rain undertakes a similar project to that of On the Contrary, focussing on an individual who examines the past in order to understand the present and move forward into the future. However, in contrast to Estienne's experience, Martin's journey into his inner psyche never develops into madness, either symbolic or literal. Martin remains firmly rooted in the realities of his past and present and it is perhaps for this reason that his particular awakening is more successfully configured than that of his historical predecessor. He is also, however, depicted as rootless - his various personal, relational and spatial ties disintegrate as the retrospective narrative progresses - and his inner journey is, in these terms, an attempt to interrogate and reestablish these links. There is a distinct suggestion that Martin's 'sane' investigation of his inner psyche is a more valid approach, in terms of the societal frameworks in which he exists. The text delves into the justifications of Afrikaners - those which sanction historical and contemporary oppressive practices - not merely exposing these justifications as constructed mythologies, but tracing, through the characters of Martin, Bernard and Louis, the development of an Afrikaner self-consciousness.

The text is essentially confessional. The memo preceding the text proper suggests the process of writing is a form of catharsis for the narrator and a means by

\footnotetext{
${ }^{67}$ Diala claims the novel is, in many respects, influenced by André Malraux's La Condition Humaine (1933) (9).
} 
which he may attempt to understand the events of his past and, consequently, reveal a way forward into the future. ${ }^{68}$ The nine days he spends in London writing his memoir represent an enforced period of contemplation, an opportunity to analyse the narrator's life, past, present and future: "the departure from routine forced me to take stock" (72). The central event on which this contemplative record focuses is a weekend trip to his family farm, in which he attempts to convince his mother to sign documents necessary to sell the property. It is a return to his origins, to the Calvinist, Nationalist upbringing which has shaped his identity and the record of that event. Memories continually intrude into this recounted experience and his writings become instead a narrative of "the individual and his context" (257). He claims, "I have no choice but to take an unfaltering look not only at that weekend, but beyond it - the way one would peer through a windscreen smeared with gnats - at the entire landscape of my life. Perhaps that is the only remaining hell" (342). This "hell", in which self-critique, and ultimately self-condemnation, threaten the very foundations of identity - of selfhood - has long been avoided. The sense of danger inherent in this form of contemplation is clear. Martin is fearful of what may be revealed in reflecting on the past: "what awaits me at the end I am, in fact, reluctant to face" (283). This fear is justified, as Martin recounts a multitude of ancestral stories and anecdotes from the distant and recent past, each of which provides opportunity to consider his role in society and his relationships with family, friends and others, while simultaneously representing his avoidance in describing the crisis of identification to which his story leads. At every turn, the novel suggests, there is an opportunity for Martin to face the guilt and complicity surrounding his Afrikaner identity, and yet the narrator persists in justifying or refuting any suggestion of guilt or blame. Set against the narratives of former friend and convicted activist Bernard Franken, the disillusioned and "liberal" commentary of Martin's son, Louis, and the liberal actions of his mistress, Bea(trice) Fiorini, Martin's increasingly uneasy justifications are constantly undermined. The result is an examination of Afrikaner

\footnotetext{
${ }^{68}$ This relationship between author and text may also be extended to Brink as author. The reader is also involved in the cathartic process. As Gordimer suggests, such texts create "the Aristotelian effect [...] a catharsis of white guilt, for writer and reader" ("Living" 273). For the black reader, Gordimer suggests, the process is one which relieves "self-pity" ("Living" 274).
} 
psychology, a voyeuristic view of the imagined Afrikaner who recognises his secure and privileged life in South Africa is about to end.

\section{The Afrikaner/Narrator as Epitome of Afrikanerdom:}

"You Afrikaners are all imperialists by nature.

Always want to be the boss, even in love"

(Brink Rumours 429).

Early in Rumours of Rain Martin states, "I am an Afrikaner. I'm a Nationalist. I've never had any reason to be ashamed of it. On the contrary" (53). This attitude frames the text, and all that follows is set against such declarations. Martin is characterised as the epitome of Afrikanerdom, a middle-aged, wealthy Nationalist who was raised as a Calvinist. (Self-)depicted as a successful businessman with a talent for negotiation, he is involved in mining, an industry which exemplifies the plundering of the land and its resources, including the use of cheap 'black' labour $(339,375)$. He is likewise stereotypical in his continual justification for the privileged role he, and Afrikanerdom in general, holds in South African society. Martin is essentially a mouthpiece for the justificatory claims of Afrikanerdom in answer to charges of exploitation. He attempts to justify the exploitation of land, of cheap labour and of the wealth of the country - exploitation he himself is guilty of. His claims are viewed as the hollow assurances they are: the reader remains aware that the statements by which he excuses himself and his people are those of a man clinging desperately to a few central tenets, each of which is merely a pretext for oppressive and exploitative practices. These justifications extend from the individual to the collective: seemingly, Martin is as comfortable excusing himself from blame for his marital infidelities as he is in justifying the oppressive role of Afrikaners in South Africa.

The apartheid mentality seemingly endorsed by the narrator also extends to his personal sphere. Segregation of society is mirrored in the narrator's personal life, 
a form of 'personal apartheid': "One tries to keep the different parts of one's life apart" (395). This segregation is not merely a separation between his mistresses and his wife, or between the business world and his home-life, but is rather the deliberate retention of distance in all of his relationships. He upholds a personal 'policy' of non-involvement $(32,52)$ on the basis of which he refuses to engage in situations of confrontation or emotional attachment. The suggestion is that Martin is acting against a natural instinct, waging a constant battle against an urge towards union. This resistance is notable in light of Brink's earlier endorsement of union as a means to effect social and political resolution. The natural instinct which Martin resists offers some sense of hope for the future possibility of union. This 'policy' of emotional detachment ostensibly justifies his refusal to confront the injustices of his environment. He remains instead aloof, detached and, he asserts, 'secure'. When Martin describes his increasing fascination with Bernard's court case, he notes, "I blamed Bernard for undermining my resistance" (70): here, Martin's policy of noninvolvement is threatened and he is drawn, by his friendship with Bernard, towards issues with which he refuses to engage. In contrast, Bernard exemplifies commitment, asking, "How could I remain a passive spectator while others were suffering?" (139).

Martin's resistance to others reflects the fear associated with the unknown. A recurrent concern with knowledge of self and others suggests not merely that Martin fails (or refuses) to explore or know another, but that he also refuses to engage with himself. This fear of both the other and of self is inherent in the very concept of otherness. Gilman's examination of the "myth of otherness" - as discussed in an earlier chapter - clearly delineates the basis on which this fear is grounded. Examinations of self and other reveal the mythologising by which the concepts of selfhood and otherness are defined and maintained. Because these mythologies represent the very basis of identity and identification, the recognition of their falsity consequent to self/other-examination - instigates a crisis of both individual and collective identity. Martin's engagement, or confrontation, with his innermost beliefs, is ultimately undertaken as he writes his narrative. At the novel's close his 
'resistance' is undermined: "I've tried with so much care to keep all the elements of my life apart and intact. But now they merge and run into each other like streams of rain forming rivers and pools and dams. [...] Does one inevitably become the victim of one's own paradoxes in the end?" (446).

Initially, the novel appears to endorse the privilege of Afrikanerdom, justifying Afrikaner control of non-white South Africans and of South Africa's economic realm: however, these justifications are soon undermined. As Martin's narrative progresses, the reader senses that the protagonist protests too much: there is an increasing tension between his justificatory claims and the opposing views offered in the text. Martin's narrative is constantly interrupted by those of other, more liberal, narrators. The first of these is that of Bernard and consists of his statement from the dock made immediately prior to his sentencing (64ff). ${ }^{69}$ Bernard is charged with

twenty-three indictments under the Terrorism Act and the Suppression of Communism Act, referring to a countrywide organisation aimed at urban terrorism, sabotage and even political assassination; the recruiting and training of guerillas abroad; the distribution of inflammatory pamphlets; the stockpiling of grenades and other arms, etc. (68)

Bernard and his values are characterised in opposition to those of Martin, his former friend: Martin's Nationalism, for example, is countered by Bernard's involvement in terrorist attacks against a government he believes guilty of injustice and oppression. For example, Bernard's court statement, in which he justifies his actions, is juxtaposed with Martin's similarly justificatory memoir. Likewise, the experiences of Louis, recently returned from military service in the Angolan War, indicate a change in direction - towards liberalism and away from Nationalism -

\footnotetext{
${ }^{69}$ Bernard's statement from the dock echoes that of South African advocate and activist Abram Fischer who was charged and convicted with having furthered the aims of the Communist Party.
} 
which contrasts with the beliefs of his father. ${ }^{70}$ Indeed, Bernard's dissident counter to the justificatory narrative of Afrikanerdom continues in the figure of Louis. This reading, however, is too simplistic. It is important to emphasise the manner in which the narratives of others are retold by Martin: his is the viewpoint from which these dissident voices are relayed. Thus, they indicate an uneasy relationship - indeed, a confrontation - in the mind of the narrator, between opposing views. There is a sense that the narrator's way of life, and the beliefs he espouses, are challenged by the more liberal views he actively suppresses: he claims, "There was no need for me to believe in the sort of life I led. I only had to live it" (265).

As I have noted, Louis' narrative is centred on a change in his view of society and of his place in it: likewise with those of Bernard and Martin. Like the re-births of the author, Brink - depicted as critical moments in which one's relationship with the world is crucially altered - Louis, Bernard and, ultimately, Martin, experience similar epiphanies. After his return from Angola, Louis notes

You know, Dad, I never used to bother much about religion before I went to Angola. I mean, it was all right, it didn't hurt me. But over there God began to sort of worry me. I was a good Nationalist when we crossed that border. But when I saw what sort of war we were really fighting and what was behind it - sorry, Dad. It taught me to puke on everything I'd believed in before.

Importantly, Louis' rejection of some of the central tenets of Afrikanerdom religious faith and Nationalism - is based on his disbelief in the justifications for South African involvement in Angola: he remains disillusioned with the political and social frameworks and actions of his society. Likewise, Bernard becomes dissatisfied with the apartheid government and its policies. In a description echoing Brink's own first re-birth, Martin recounts Bernard's claim to an awakening linked to meeting blacks "on a basis of social equality" at a university in Holland. After contemplating his initial resistance to this interracial contact, Bernard claims, "What became

\footnotetext{
${ }^{70}$ Interestingly, a section of Louis' disillusioned commentary regarding the Angolan conflict is absent from the Afrikaans version, suggesting some concessions were made in a text designated for Afrikaans
} 
abundantly clear was that $[\ldots]$ I had developed an antagonism for which I could find no rational basis whatsoever" (92). Importantly, Bernard recognises the irrationality of Afrikaner justifications: they are both invalid and, (it is implied), constructed. He notes that this experience "was the beginning of a process which I had to see through to its logical conclusion - philosophically, morally and, in the final analysis, in practice" (92). Compared to the re-births of both Bernard and Louis, Martin's awakening is less simplistically realised.

Martin's surname, Mynhardt, reflects his metaphorical re-birth or awakening. While the surname is emphatically Afrikaans, it suggests a German or old Dutch derivation translated as "my heart". References to Martin's heart, or to his heartlessness recur and are centred on a Biblical phrase he remembers from childhood: "And have not love" $(189,312)$ echoes throughout the novel, reflecting Martin's emotional detachment from his country and its people. This heartlessness is viewed against the backdrop of Martin's early years, a time he describes as his "Early Romantic Period" (351), prior to his denial of emotion. The heart motif culminates in a literal and figurative crisis of the heart which drives the narrative: Martin's recent coronary, which occurred during sexual intercourse with his mistress, is its physical manifestation (442). Martin's heart is both literally and figuratively under pressure, and he is forced to become attuned to its needs, tailoring his actions to ensure its continued health. Figuratively, he must examine his inner self - his identity, place in society and connection to others - in order to build 'healthy' relationships. This is the premise of the novel as a whole, in which such examination takes place. Remembering his now deceased father, Martin recounts his belief that

One has got to open one's heart to history, you see, to find out what it really wants to say to you. You can't just sit down and read it like a book. Even though it may all be printed in books, you need a code, as it were, to decipher it. A matter of interpretation. [....] I mean, trying to reshape and hone one's definitions. What does it mean to be a Mynhardt? What does it mean to be an Afrikaner? (223)

readers (Brand J. Toerien 549). 
These are the questions under examination in Martin's memoir.

The ostensibly legitimising myths which shaped Martin's life thus far are revealed as constructed mythologies, resulting in a fracturing of his Afrikaner identity. His memoir is, in these terms, a deconstruction of the foundations on which the narrator's life has been based: his ideological context is irrevocably altered. Thus, the novel fulfils Coetzee's definition of "the literature of truth", described as "a fiction centring on a crisis of illumination, retrospectively narrated by a speaker (now a truth-bearer) about his earlier, (self-) deceived self' (Attwell 262). 


\section{White Guilt?}

"No one can hold me responsible for what happened, damn it"

(Brink Rumours 40).

During his process of self-examination, Martin asks, "Could it be argued that, like Pilate, I'm trying to wash my hands? Possibly" (100). Throughout the text, he raises questions of culpability and responsibility, a line of inquiry common in postcolonial theory and literature, in which the guilt of colonisers (commonly white Europeans) is a central issue. Early evidence of this questioning includes his reflection on a series of incidents in which others were killed or injured while he remained unharmed: he notes, "I have often wondered, not without cynicism, whether perhaps I have a 'gift' for this, acting almost as a catalyst for violence which breaks out all around me yet leaves me unscarred" (28). His statement contains a suggestion of guilt: he is, perhaps, "a catalyst" - instigating a reaction without being himself consumed - and yet the justificatory and defensive tone of the remaining narrative denies blame. The guilt-tainted and yet justificatory stance epitomises that of the Afrikaner, complicit in her/his environment, whether through non-involvement or active oppression, but yet ideologically sanctioned from blame.

The text resounds with references to guilt and innocence, which are granted further significance by the religious imagery of the text. In keeping with his characterisation as an imagined stereotypical Afrikaner, religious faith plays a significant role in Martin's ancestral heritage and familial upbringing. The Bible remains the authoritative text by which Afrikaners justify their oppressive role in South Africa. In this model, the guilt of Afrikaners is traditionally voided by justifications derived from a higher authority, God. The text's return to notions of innocence and guilt, however, undermines this simplistic model. Throughout the novel there is a pervading sense that Afrikaners are tainted with both complicity and guilt. At the moment when Martin realises his son is amongst the crowd of onlookers waiting for a black man to jump to his death, he demonstrates an understanding of 
complicit guilt. He wishes Louis were not witness to the suicide, claiming "I would have preferred one of us to remain innocent, unblemished by our presence in the crowd" (34). Here the narrator suggests not merely the sense of taint derived from witnessing horrific events, but also a suggestion of complicity attributable to the onlooker. Read in the context of Martin's constant return to scenes in which he both avoids involvement and instantly offers justification, this taint is clearly that of complicity, the blemish attached to those who bear witness, but refuse to assist.

In contrast to Martin's association with guilt, characters such as Bernard, who exemplifies a commitment to involvement in his society, are aligned with "Innocence" (34). This binary relationship is crucial in both individual and wider social contexts. Martin associates the notion of innocence with its binary counterpart, guilt: "It is not a positive or real phenomenon, but simply the denial of the real phenomenon, guilt. It is part of our social foundation, part of our Christian tradition, that we are guilty by definition. Our dimension is that of guilt. The opposite, i.e. innocence, is an un-condition, an absence, a negative, a denial" (370). In these terms, the narrator's previous justificatory claims, in which his innocence is foregrounded, are predicated on the very notion of guilt.

The importance of Martin's individual examination of complicity and guilt in the context of the nation is made clear: "Perhaps there is a similar transition from a state of innocence to a state of guilt in historical process" (370). Further, he notes, "I was heir to an entire history of violence, revolt, and blood. In the historically extreme situation like ours there is only total complicity" (370). This is Martin's ultimate acceptance of the guilt of Afrikaners, a statement in direct contrast to his previous denials. Earlier, in response to Charlie Mofokeng's accusation that every white in the country is responsible for the current situation, Martin characteristically excuses himself from blame, claiming the South African "situation" is an inheritance - for both black and white - from previous generations. Further, he states, "I can't stand the attitude of people who, the moment things start going wrong, assume that all the blame must lie with us for the sole reason that we're White" (110). Such statements 
provide a point of reference by which to measure Martin's movement away from the justification and denial of the imagined Afrikaner to his later acceptance of collective responsibility, complicity and guilt.

Central to the text's examination of the position of Afrikaners is not merely the historical blame by which Afrikanerdom is judged or condemned, but also the role Afrikaners may play in the nation's future. Bernard suggests that the central issues of South Africa's future are not whether a black majority will rule, or when; rather, he asks, can a change of this nature occur peacefully and - crucially - what position will Afrikaners have in this new society? Further, he claims,

In both respects the Afrikaner himself finds himself in a decisive role. It is he who is in power; which means that it is he who is blamed for the evils and humiliation of apartheid. But it also means that he is in a position to negotiate a peaceful changeover, provided he is really sincere about it; he can eradicate such wrongs as may later give rise to a justified call for vengeance. In this situation it has become imperative for me to act as an Afrikaner.

[....]

As a White, as an Afrikaner, linked through the colour of my skin, and through my culture and my language, to that group which is in power in this country, my choice is different. I am free to reap the fruit of my White superiority while it lasts. Or I may choose to do nothing at all. But a third course is open to me. And as a thinking and feeling man my only freedom today lies in renouncing, for the freedom of others, everything I might otherwise lay claim to, not through any merit on my part, but through the condition of my birth - which is the epitome of bondage. No man is so completely oppressed by the oppressor as himself. (134; original italics)

Bernard's recognition of the mutual bondage of oppressor and oppressed motivates him to create some sense of personal freedom. He chooses to resist this entrapment by refusing to fulfil (or perhaps refusing to continue) the role of oppressor. Likewise, at the novel's conclusion, Martin is faced with the three options outlined above: he 
may continue to benefit from his position of privilege, he may do nothing, or he may renounce privilege: these are the choices available to every Afrikaner. ${ }^{71}$ Although it is suggested that Martin will choose renouncement, the novel is ultimately equivocal: his personal indeterminacy may be seen as a depiction of the uncertainty of imagined Afrikaners. Interestingly, Albert Memmi notes that 'the colonizer who refuses' - one who is both aligned with, yet resistant to an oppressive group -

invokes the end of colonization, but refuses to conceive that this resolution can result in the overthrow of his situation and himself. For it is too much to ask one's imagination to visualize one's own end, even if it be in order to be reborn another; especially if, like the colonizer, one can hardly evaluate such a rebirth. (Memmi 40-1) ${ }^{72}$

Resistance to one's own destruction, as posed by Memmi, may explain Martin's equivocal position as the novel concludes. Earlier, I suggested that the enquiry framing Rumours of Rain is a common aspect of postcolonial examinations of white guilt - such as Memmi's. Brink's text responds to these types of questions regarding white positioning and culpability - with questions of its own: it concludes with a question, rather than a resolution, asking what role will Afrikaners have in a new society?

In Bernard's case, the guilt he assumes as a member of a privileged group prompts him to become dissident, to act against those with whom he is historically aligned. However, as Martin tells him, he can never fully renounce his position as an Afrikaner, nor the blame attached to that role: "Your position continues to be determined by the group you've tried to break away from" (162). ${ }^{73}$ This is the tragedy of Afrikaners: they can never entirely abandon the complicity and blame symbolised by privilege: every action or inaction is framed by the context of a 'superior' - here specifically Afrikaner -identity. The ideological implications of

\footnotetext{
${ }^{71}$ Notably, Memmi states that "accepting the reality of being a colonizer means agreeing to be a nonlegitimate privileged person, that is, an usurper" (52).

${ }^{7}$ Disappointingly, Memmi argues that the inevitable result of this untenable position is the reduction of 'the colonizer who refuses' to silence (43),

${ }^{73}$ Likewise, in the colonial context, Memmi argues that, "Accepting his role as colonizer, the colonialist accepts the blame implied by that role" (51).
} 
one's upbringing and social ties continue to frame one's collective identification, if not individual identity. Bernard argues that, the taint of the oppressor remains. This is crucial in terms of Brink's own imperative to speak against that which has framed him: as I have suggested, he is dissident, but also remains undeniably complicit. What remains unclear is how removed future generations may be from the complicity of their ancestors. In this respect, Elazar Barkan asks, "Is there a statute of limitations on national injustices?" (xxviii). Will new generations be freed from the stigma of past injustice or will they simply abdicate moral responsibility for acts committed by previous generations? An answer is not offered in Brink's texts: rather, his novels suggest that the possibility of future forgiveness and reconciliation depends on the confessional stance and acceptance of responsibility of Afrikaners.

\section{Apocalypse}

"If He [God] wants you to suffer, you blerry well suffer.

And if He decides to wash you away, it's a worse flood than the one that hit old Noah"

(Brink Rumours 90).

The indeterminacy of the future is aligned with a sense of impending doom. The literal and figurative aridity of A Dry White Season is deployed in Rumours of Rain in similar ways, and rain is the longed-for solution to drought. However, in association with the novel's collection of images, the titular suggestion of rain instigates feelings of both hope and fear: hope for resolution to the nation's metaphorical aridity is countered by (white) fears of a 'flood', a social and political apocalypse of Biblical proportions. Images of apocalypse frame the narrator's commentary and are reinforced by water imagery. As a boy, for example, Martin was rescued from drowning by a black child named Pieletjie. Echoes of this memory permeate the text and return to Martin in a "dream" (nightmare): 
There's this dam with a water-lily in the centre growing all the time. I want to wade in to pick it for Bea who stands waiting on the other side. But the moment I touch the stem, my feet are caught in quicksand. Out of the corner of my eye I can see a black shadow hovering on the edge. It must be Miplo, but he looks like Charlie. 'Help me!' I scream. 'Help me, I'm sinking!' But he stands there with his arms crossed, watching me sink into the muddy water until I drown. Of course, it's only a dream. (59)

Crucially, it is in moments such as these, when his subconscious gains control, that Martin's sense of impending doom is most clearly envisaged. Martin's future is in the hands of the "black shadow", a figure offering the possibility of rescue and threatened inaction. S/he ironically enacts the action/inaction dichotomy by which Martin lives: non-involvement will result in his demise. The water-lily is also a threatening image: later, it is described as a plant which doubles in size each day, until it covers half the pond and there remains only one day to destroy it before its suffocates everything beneath (283). Clearly, Martin recognises, but refuses to consciously acknowledge, the impending crisis of his nation and of his people. Also paramount is his inability to see a future beyond the apocalypse symbolised by the ever-increasing lily.

In a complication of this imagery, water is also related not merely to impending crisis or doom, but also to a sense of freedom. It is on the rapids at Aughrabies Falls, during a canoe-trip with Bernard, that Martin feels most free. The thrill of danger and the ultimate defiance of death appeal to his competitive nature and revitalise him (38-40). Clearly, the impending flood, a possibility suggested by the novel's title and referred to in its imagery, represents a multitude of powerful and mixed emotions, in which doom is linked with the possibility of hope.

The vulnerability of the Afrikaner position is exposed here: her/his place of privilege is untenable, and yet there appears no acceptable alternative. This vulnerability is metaphorically envisaged as Martin commences his weekend trip to the family farm. A swarm of gnats is plastered against the windscreen of his 
Mercedes and the windscreen washer fails to operate $(11,62)$. Martin is suddenly exposed to a threat from his environment, and to his own vulnerability: he is unable to clear the gnats and does not possess the skill to investigate and repair the mechanical failure: “it made me feel, momentarily, that I wasn't in complete control; as if something had taken its course against my will" (66). The Mercedes, which has until now represented "security", now symbolises both the vulnerability and futility of the laager mentality. Simultaneously, the mass of 'insignificant' insects suggests an amassing of resistance to white power: the threat inherent in this image recurs throughout the novel.

Martin is forced to drive with obscured vision, the first of many metaphorical references to the need for a new perspective which prefigure ultimate illumination: "One can still see, even though it's through a glass darkly" (66). Here, Martin's impaired vision is "the myopia of the White South African" as described by Bernard (133) and most powerfully envisaged when Martin breaks his glasses and the familiar landscape of the family farm is suddenly altered, "all familiarity gone" (205). He notes, "Looking back on it now, the impression I have is not so much that the vagueness of myopia causes one to feel isolated and remote from everything, but rather that one is exposed to space and left without any protection against objects invisible in the distance" (217): this is the vulnerability of Afrikaners whose delusions have been erased and who are forced to view the environment from a new perspective, beyond familiar ideological frameworks. The suggestion is that only with illumination, or enlightenment, may Martin move beyond the constraints of his environment. 


\section{Expiation}

"like rain trying to wash out the scars of drought

(but something always remains)"

(Brink Rumours 29).

Throughout my examination, I have referred to a series of metaphorical rebirths which have shaped Brink's work. Rumours of Rain fictionalises a specifically Afrikaner re-birth. It traces a progression - from denial and justification, towards acceptance of a complicit role and consideration of one's future position and responsibility in the nation. In essence, this type of re-birth is from a traditional, stereotypical Afrikaner, an oppressor in the apartheid regime, to a contemporary version in which dissidence and the future possibilities of post-apartheid Afrikaner identity are posited. Throughout the text, Brink examines the ways in which privilege and oppression are justified and excused from within Afrikanerdom. The historical context from which this white privilege is inherited is that of On the Contrary. Estienne's extended confession provides an imagined historical precedent by which to examine the guilt of contemporary - specifically white - South Africans and outlines one possible (though centrally problematic) model for resolution and communion in contemporary apartheid South Africa. The confessional model offers the possibility of atonement, suggesting either punishment, forgiveness or a combination of both, as a means of expiating the past privileges associated with whiteness. As I have noted, however, Estienne pays an extreme price for his journey of self-discovery, losing his life. In these terms, the text is largely despairing of the process it outlines.

Rumours of Rain explores similar issues in a contemporary context, and simultaneously traces the urge towards dissidence, resistance to the exploitative role of the imagined, oppressive Afrikaner. Brink does not, however, imagine the movement from complicity to dissidence as a simple exchange of values, nor does he envisage it as a journey from guilt and blame towards innocence. Instead, he 
suggests that the associations of white privilege and the oppressions of apartheid inevitably and continually taint Afrikaners, regardless of her/his political or social views: Afrikanerdom and privilege are indelibly linked. Afrikaners who choose to challenge the ideological frameworks of Afrikanerdom become exiles, in some sense, while remaining exiled from non-white South Africans.

While the above claims may imply that Brink's fictional representatives of Afrikanerdom are idealised martyrs, the novel delays any possible redemption or exculpation: Bernard is imprisoned for life, the future of the rebellious Louis is uncertain, and the reader is denied full disclosure as to Martin's future. Rather than offering a simplistic solution to the problematic role of Afrikaners in South Africa, Brink instead outlines the issues, sketches some possibilities and raises questions. He forces readers to consider issues of complicity, blame and guilt. In Rumours of Rain Brink examines the manner in which contemporary imagined Afrikaners are entrapped in an historical and contemporary web of oppressive practice. He neither excuses nor endorses Afrikaner complicity, but rather examines the psychology of those forced to deal with the consequences of past injustice. His scrutiny of Afrikanerdom and of 'white guilt' is not a self-absorbed or self-pitying exploration of his own position but rather another facet to his ongoing examination of the larger social and political environment of his nation. The questions he raises are a further contribution to the cultural conversation initiated in earlier texts.

As I have noted, a number of crucial questions reverberate throughout the texts, questions which relate to the manner in which reconciliation may be realised. Each of these questions is underscored by, and leads to, a central concern unarticulated in the texts but which frames them both: what role will 'white South Africans' play in a new society? In Rumours of Rain, in particular, the recurrent references to apocalypse symbolise not merely Martin's struggle towards acceptance of guilt, but may also be viewed as the author's (perhaps tangential) exploration of an era beyond white control. Long before the end of apartheid, Brink imagines an impending apocalypse after which the white position in South Africa will irrevocably 
alter. The recognition that white rule will end is arguably the motivation which drives Brink to so consistently concern himself with the problems and possibilities of reconciliation, before that crisis occurs. During the period in which On the Contrary was written (May-December 1992) it was becoming increasingly evident that the apartheid regime was in its final death throes and that its dismantling was inevitable. In this context, Estienne's final insane and somewhat desperate rhetoric may be viewed as an increasingly desperate plea, on the part of the author, for some model in which white South Africans (and, in particular, Afrikaners) may redeem themselves. In this way, Brink highlights the Afrikaner desire - indeed need - to move from disgrace to grace.

Rather than becoming mired in debate as to whether Afrikanerdom is guilty of injustice and to what degree, Brink assumes the guilt of Afrikaners in the apartheid regime and continues his investigation of possible models for the future reconciliation of South Africans. Not merely are his protagonists cast in the roles of confessants, but so too is Brink himself - he enacts the process he endorses. In the two texts under discussion in this chapter, the author gestures towards a concern central to his work - the belief that, in order to move beyond past wrongs, they must be resolved. The self-examinations undertaken by Estienne and Martin are not merely individual, but also represent larger examinations of white complicity, responsibility and guilt which echo throughout Brink's oeuvre. He examines white guilt and offers a confessional model, in which the possibility of forgiveness and/or atonement exist. This model is not touted as a complete curative, nor as a means of eliminating guilt; rather, it is posited as a preliminary stage in an ongoing effort to address the burden of guilt experienced by specifically white South Africans; it is a sign of good faith. There is little emphasis placed on the post-confessional situation; instead, the focus is on the need for confession itself and for a movement from disgrace to grace. In every instance, Brink implies, Afrikaners must assume their guilt and initiate a process of reconciliation. 


\section{CHAPTER 6}

\section{Metafictional Challenges to Truth in}

On the Contrary

"History, too, is just another story"

(Kossew "Anxiety" 74). 
In earlier chapters I demonstrated that apartheid South Africa is founded on the conceived superiority and exclusivity of the elite. This set of beliefs is evident in both contemporary and historical records of the nation and its people(s). Traditionally, the nation has asserted singular renditions of pivotal historical moments. The first colonial encounter, for example, is narrated solely from an Afrikaner perspective, as is the Anglo-Boer War and the implementation and practice of apartheid ideology. In direct contrast to the proscriptive and prescriptive tenets on which the apartheid state is based and white history is narrated, postmodemist and poststructuralist theories emphasise that history and reality (in as far as it can be known to the percipient subject) are provisional, a result of their necessary mediation through linguistic structures. The use of postmodernist devices such as textual selfreflexivity and the textualisation of the world may be viewed as a development of the existentialist focus found in Brink's earlier texts, further extending his demonstration and critique of preclusion and prescription.

Metafictional devices draw attention to the fictional status of texts to foreground questions of authority, truth-claims and trans-ontological relationships. Brink uses these techniques to represent and perform a challenge to authority, demonstrating the ways in which both writing and language mediate truth. All, he suggests, is representational. In On the Contrary, Brink uses metafictional techniques as tools of dissent in response to prohibitive and censorial environments. Each of these texts employs metafictional techniques, urging the reader to consider not merely the fictional world created, but also the creative process. Further, the reader is urged to reflect on the implications of narrative construction beyond the fictional realm of the text; as Kim Worthington suggests, metafictional texts "invite the reader to share in the kinds of epistemological and ontological uncertainties engendered by the selfconscious inspection of narrativization as a mode for understanding" (17). Again, Brink's mandate appears to be not merely to confront his social and political environments, but to encourage his reader to do the same. 


\section{On the Contrary}

"the truth of my lies"

(Brink Contrary 225).

Published just one year before the dismantling of the apartheid regime, and dated May - Dec 1992 (376), On the Contrary returns to an historical era in which the nation and its inhabitants were being defined. In doing so, the text examines the historical South African context in order to imagine the creation of a new South Africa beyond the predicted fall of apartheid. The novel narrates both the official reaction to the colony and also a series of responses which contest the exploitative and controlling version of the coloniser. The protagonist Estienne's journeys across the land are mirrored by his inner journey in which he comes to critique Western epistemology and judgement (Kossew, "Anxiety" 70) and his involvement in these structures; as in much contemporary literature, the journey is emblematic of an interrogative experience.

The text represents a challenge not only to the recorded (colonial) history of South Africa, but also to textuality per se. In terms of form, On the Contrary is as resistant to categorisation as is its protagonist. Ostensibly a letter written to an illiterate slave-woman, this 'novel' is merely a series of excerpts which refute the traditional form of the genre. The manner in which they are both achronological and yet also numbered suggests that the author, or his implied authorial counterpart, purposely plays with the traditional notions of linearity and cohesion. Further, the majority of the numbered passages are extremely short, sometimes consisting of a mere sentence. This fragmentation of the text and the extent of blank space on the pages implies physical disintegration, a specifically postmodernist tendency. The text is also resistant to classification in terms of genre: the content is often framed in terms of an historical novel and yet its magic realist elements and the fragmentary narrative method do not fit this model. On the Contrary is a pastiche in which a variety of traditional genres - historical record, the epistolary narrative, myth and 
confessional - are imitated and reinvented. Further, frequent references to philosophical and literary theory, and the inclusion of reference notes and other critical appendages in an otherwise 'fictional' text, undermine the reader's attempts to classify the text's genre. In every sense, the form of the text defies categorisation, refuting traditional forms - those which attempt to disguise the distance between lived and written experience - and instead foregrounding the constructed quality of the text. Thus, the form of the text mirrors and reinforces the subversive theme of the novel: each rebels against constraints. The textual experimentation of $O n$ the Contrary echoes one of the central tenets of the Sestigers movement: Brink adopts new forms in order to engage with his material in innovative ways. This movement away from the traditional forms of the novel and its related literary conventions may be viewed as a further re-birth in Brink's literary development, this time in terms of literary technique and form.

Estienne's account is also a commentary on the disparity between language and that which it describes, a narrative disjunction from the ontology of the real. The text is permeated with references to "the inadequacies of [...] language" (356) and with characters "Unable to find words" (230) to describe their experiences. Drawing on a poststructuralist understanding of language and its relationship to reality, the text undermines the conventional modes of representation by which the world is narrated. Estienne's text exposes the manner in which language, as a means of representation, creates, rather than conveys, meaning. Rosette's inability to de-code Estienne's text

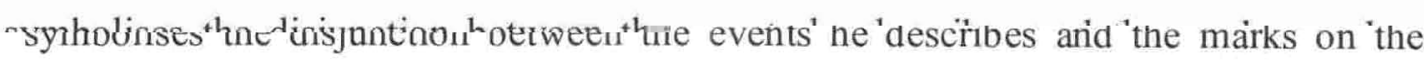
paper which represent those events - a disjunction independent to her illiteracy. Further, the inaccessibility of the text suggests the direct disjunction between the reader and the writer, via the text. ${ }^{74}$ A comparison between written text and "the loops and sentences inscribed by a bird in flight on the parchment of the sky" (147-8) reinforces the sense that written language is as arbitrarily conceived as its spoken counterpart. Rosette's inability to 'read' is due to her lack of knowledge of the signs which represent reality, suggesting that these are not essential, but rather constructed.

\footnotetext{
${ }^{74}$ See Barthes" "The Death of the Author" (1977) for further commentary in this vein.
} 
Thus, it is understood that it is not merely Rosette's illiteracy which disallows her knowledge of the text, but a disjunction between language and meaning. In this way, Estienne's narrative is exposed as a construction, ultimately deconstructed.

Estienne himself is also both constructed and deconstructed by means of his narrative, demonstrating the extent to which subjectivity - like experience - is created rather than described. Throughout, the reader is aware that Estienne is both writing and being written. The blatant exposure of Estienne's role as scribe and letter-writer foregrounds the process of writing and, in the context of a text which is constantly re-written, the reader recognises that Estienne is also vulnerable to rewriting. Estienne himself makes this clear: "this curious, disturbing sensation of being at odds with myself [...] not of writing but of being written; not of observing, but of being observed" (183). This sense of observation is aligned with that of being read and thus invokes the role of the reader at the level of interpretative construction. In instances where Estienne feels vulnerable and exposed, impotent against the higher authority of his employers, the Dutch East India Company, his feelings are likewise phrased in terms of writing: "from a great distance I observed myself, saw myself being written into a part I had no wish to play yet couldn't resist" (194). In these terms, it is the authorities who are 're-writing' Estienne; however, simultaneously, the reader is alerted to a further level of authorship, that of Brink himself. The inclusion of an acknowledgements page at the text's close reinforces this notion of an ongoing layering of further authors (374-6). The implication is that every author is her/himself written and that, in these terms, narrative is a continual transtextual play although, admittedly, with a crucial imbalance of power between ontological levels.

In the text itself, it is suggested that authority, power and control reside with those who write rather than with those who are written. The power of the pen is, in this framework, a metaphor for the authority of those who determine acceptable 'truths'. The apartheid state, like the Dutch East India Company of the text, prescribes truth by means of historical record, legislation and prejudicial practice. The subversive nature of Brink's text lies in its exposure of the constructed and 
arbitrary nature of this discourse and in its provision for alternative discourses. The novel avoids the authoritarianism of that which it challenges, not merely by positing an alternative to the prescriptive and static discourse of the authorities, but in offering a series of alternative narratives, each of which is in itself undermined. The use of metafictional strategies which foreground competing accounts undermines the authority of espoused, fixed truths and instead establishes a palimpsest of alternatives.

Each of the narrator's narratorial positions is undermined in the subversive context of the novel. Further, the use of metafictional devices such as textual selfreflexivity overtly encourages a subversive mode of reading, undermining the authority of the text. The reader of On the Contrary is immediately alerted to a certain subversive quality in the text, an aspect highlighted prior to the first page. The titular phrase "on the contrary" 75 heralds the foregrounding of dissent, of contradiction, reinforced in the novel. It is also placed in parentheses, as are the subtitles to the three parts which divide the text: these brackets operate as markers which point to the undermining of a singular author-ity, labelling the text as a supplement, another version to contest a singular historical rendition. Likewise, the appended subtitle - in the manner of Moll Flanders - suggests narratorial unreliability: "Being the life of a famous rebel, soldier, traveller, explorer, reader, builder, scribe, Latinist, lover and liar" (title pag.; emphasis added). Thus the title establishes the inevitable incoherence of the text proper, foregrounding the impossibility of gaining access to the truth of Barbier's epistle. In this way, the reader is coerced - arguably forced - to participate in the text's seditious conduct.

There is a constant tension in the text between that which is considered 'truthful' and that believed to be 'false', between belief and disbelief. This tension is foregrounded in the novel's subtitle, quoted above, in which the unreliability of the narrator is highlighted. Further, the opening sentence of On the Contrary establishes

\footnotetext{
75 The novel's first epigraph attributes this phrase to Henrik Ibsen, claiming these words were his last (n. pag.); (Brink "Writer in a State" 181).
} 
the putative impossibility of the text in its own ontological terms. The statement, "I am dead: you cannot read" (3), ${ }^{76}$ places two of the text's central characters beyond the realm of the narrative in which their stories are told: Rosette, an escaped slave, is illiterate and therefore unable to make sense of the text, while the executed narrator has no writing implements and is therefore ostensibly unable to write it. The unreliability of both the narrator and the intended recipient of his letter is foregrounded immediately, suggesting the manner in which the text will engage with issues of narration. This mistrust of the text's authority is central to an investigation of not merely the various versions posited as truth, but also of the concept of truth itself. In this way, the ideal reader is encouraged to participate in Estienne's consideration of the nature and extent of truth.

The various narratorial levels of the text also undermine the notion of a singular, fixed or verifiable truth. Much of Estienne's narrative is a retelling of stories or events and his own narratorial stance is often far removed, both spatially and historically, from the original narrator and/or events. Like Looking on Darkness, Estienne's narrative operates in an imaginative realm, beyond the 'factual' constraints of traditional historical records and real world expectations of causality. In this context, the concept of truth itself is considered:

All ages, since writing has been known in the world, have produced as does the present, and as doubtless will every one to come, swarms of the ignorant and the designing to plague the world with mutilated fact and historical fiction. Few people apprehend how truth may be injured by the Melancholic, the Phlegmatic, the Choleric, and the Sanguine tempers of the individual writers. Few have any notions of the wounds, the tarnishes and false beauties the truth may and does often receive from the reigning humour in the author. For my own part I think it does not little contribute to the discovery of truth in a history to know the temperament of the man who wrote it. It is not difficult

\footnotetext{
${ }^{76}$ As Brink notes, the opening line is derived from Derrida's "This (therefore) will not have been a book", the opening words of an essay entitled "Outwork" in which he discusses the creation of meaning through language ( 3 qtd. 375).
} 
to show that the constitution of a man frequently betrays him into a falsehood.

In outlining the motivations and humours of the narrator which may "tarnish" her/his narrative, Estienne suggests the possibility of an 'untarnished' truth. Simultaneously, his depiction of the ways in which a narrator influences her/his narrative suggests the impossibility of gaining objective access to this 'untarnished' truth. This revelation is central to the text's concern with the relationship between narration and truth. If the implied ideal, 'untarnished' truth cannot be narrated, then can it be seen to exist? If Estienne's notion of 'untarnished' truth is indeed inaccessible, then historical record and imaginative narrative are exposed as inextricably shaped and censored by individual and collective motivations. This challenge to absolute or categorical truth undermines the monolithic narrative by which history is recorded. Simultaneously, the challenge posits Estienne's own narrative(s) as provisional and supplementary, rather than definitive. Thus, when Estienne states, "I am no longer sure of what is real" (183), he points to the subjective, arbitrary nature of truth; each possibility is true, "in the sense that their truth is exchangeable" (Jean Baudrillard 32).

The relativity of truth suggested here is central to debate concerning Brink's understanding of truth. In order for Estienne's narrative to convey any meaning, it must bear some resemblance to an accepted/acceptable version of 'reality' and be framed in a manner which can be interpreted, or understood, by the reader. The fact that a single event may be multiply represented is not the same as claiming that all or any representation has equivalent representational value. Estienne's epistle, like any other form of representation, must operate in a field of mutually understood parameters of signification. His varying descriptions of key incidents do not suggest an infinite number of possible alternatives, but rather a limited range of meaningful possibilities. In respect to Brink's conception of truth, in which he envisages an interplay of multiple possible alternatives, evaluation of the meaningful nature of each is central. What is suggested is that each and every possibility must be

\footnotetext{
${ }^{77}$ The quotation is borrowed from a passage in which Baudrillard speaks of simulation and the manner in which the model and its various simulations become interchangeable, and therefore equally truthful.
} 
inherently truthful in some respect - it must operate within a pre-defined framework of 'reality'. It is implied that the narrator must participate in the narration of reality from a position of good faith, providing a rendition of experience which will add to the total pool of possible truths. Clearly, this conception raises a further series of concerns in relation to determining what is accepted/acceptable. Interpretation is both necessary and also an inherently flawed method of determining the meaningful. Who is to determine who will be muted and who will participate in this communal narrative and by what frameworks will this interpretation be undertaken? Questions such as these provide an ongoing framework against which Brink's texts must be gauged.

\title{
Madness, Magic Realism and Multiplicity:
}

\author{
"these flickering stories" \\ (Brink Contrary 137).
}

Estienne's claim to narratorial uncertainty has a marked effect on the reader as the reader's search for truth or reality is undermined. The inclusion of magic realist elements in the text defers - indeed rejects - the possibility of a static, fixed truth. Instead, the text provides a palimpsest of alternatives in which none is favoured over any other but in which all contest the unitary nature of the official version. How this equivalence is maintained among all versions but allowing all to contest one version is interesting. I contend that the text suggests not that the truth sanctioned by the authorities is necessarily untruthful, but that its claim to be the truth is false. Brink's manipulation of devices such as these ensures the 'reality' on which a character or reader may depend as a basis of truth is questioned: magic realist elements are visual metaphors for acts of narration. Brink demonstrates the mediated nature of truth by blending accepted 'reality' with the 'surreal'. The effect is to maintain a readerstance in which perspective is consistently altered and interpretation constantly undercut. 
Estienne's 'insanity', as outlined in the previous chapter, permits excursions into a surreal, alternative world, offering scope for aspects of the text which may otherwise appear untenable. The reader is granted access to an 'insane' perspective, in which the traditional boundaries between reality and non-reality, and between one version and another conflicting rendition, are blurred. The novel is permeated with fantastical creatures and improbable myths which are narrated alongside the everyday and mundane. The presence of fantastic or surreal elements refutes fixed and singular renditions of reality. In placing 'imagined' elements on the same plane as the 'real', the conventional favouring of one set of (proven) beliefs over the various (often imaginative) alternatives is challenged. Estienne's narrative stretches the boundaries of what is considered permissible in his contemporary society, operating beyond the realm of accepted 'reality' and its narration: he and his text are ex-centric. Despite Estienne's claim that his is a conscious decision to operate in the realm of madness, (282) his insanity is defined by the inability to distinguish the 'real' from the imagined. This distinction is similarly problematic in terms of the reader, whose 'insanity' suggests that the text forces the reader into a position of contestation. S/he is encouraged to engage with the uncertainties of the text but is ultimately refused any definitive resolution to the problem of truth. In this respect, magic realist techniques result in reader uncertainty, as no fixed reality is authorised. Thus, the text simultaneously undermines the concept of a fixed and singular narrative and also aligns the reader with an opposing series of alternatives.

Estienne's sighting of a unicorn provides textual evidence of the commingling of 'real' and mythical realms. For a brief moment, as Estienne sits astride his horse and identifies the unicom, both mythical and real possibilities co-exist in the same space and time - a metaphor for the various challenging accounts in Estienne's narrative(s). However, Estienne's subsequent slaughter of the mythical creature and the events which follow complicate the co-existence of competing accounts. The unicorn's slaughter reflects the manner in which the mythical is first identified and then censored and, in these terms, may be viewed as symbolic of the coloniser's desire to control. Estienne, however, describes the act of execution not as 
extermination, but rather as the introduction of "a creature of myth into the domain of the possible" (28). The unicorn's death, its decapitation and removal of the "unique horn” ostensibly 'create' physical evidence of its existence (28).

Notably, this event occurs early in the novel, when Estienne is still concerned with establishing $a$ truth and is resistant to competing 'realities'. He attempts, therefore, to merge two worlds by drawing the mythical into the realm of the real. However, the unicorn's head and horn, the "trophy" by which Estienne will prove both the unicorn's existence and his own power over it, is ultimately denied him. While Estienne attempts a reconciliation between competing accounts - the mythical unicorn and the markers of 'reality' which surround him - the ontological structures and ideological frameworks by which he has thus far existed disallow such reconciliation. Throughout the novel, there is a continual refusal to reconcile competing accounts. Estienne's efforts to effect this reconciliation represent both a challenge to the ontological rules which regulate these realms and also a refutation of their difference. In a telling footnote to the story, Estienne describes how, as he gazes at the corpse, his horse bolts into the distance. He is now alone, without means by which to carry his "trophy" back to his peers (28). Estienne's immersion into the mythical realm of the unicorn results in the disappearance of physical attachments to reality such as his horse. They cannot co-exist more than briefly because Estienne, at this point, accepts the possibility of only one ontological milieu at any moment. The next day, after his rescue, Estienne returns to the spot where he had built a cairn of rocks over the corpse. Although the rocks appear undisturbed, the corpse has disappeared, leaving no evidence of the mythical creature: it appears that his extermination of the animal is complete. His peers, who return with him to the cairn, cannot exist in the same heterocosm as the fabled creature - they are unable to acknowledge possibilities beyond accepted modes of reality, nor can Estienne reconcile their co-existence with that of the mythical beast. Thus, while the text foregrounds two different ontological realms, Estienne's stubborn hold on the 'real' ultimately instigates the disappearance of the mythical. As the text progresses, 
Estienne's descent into 'madness' allows his acceptance of competing, co-existent accounts and the mythical returns.

The impossibility that frames the beginning of the text is later extended to include all narrative. On the Contrary draws on a tradition of literature which reflects on its own narratorial construction, a tradition established long before the era of metafictional examinations of this kind. An early example is Miguel de Cervantes' El Ingenioso Hidalgo Don Quixote de la Mancha (1605; hereafter Don Quixote), arguably the foundational text of the novelistic genre. The narrator of On the Contrary carries a copy of Don Quixote on his travels, and the text becomes - like the other joumals and letters in On the Contrary - emblematic of the textualisation of experience, as well as a marker of the transtextual discourse at play. Further, the textwithin-the-text suggests the layers of discourse in operation in each and reinforces the narratorial and plot disruptions and exposures which refute the possibility of truth. Most crucially, the Don Quixote text signifies the paradox of narrative as defined by Georg Lukás: "the objectivity of the novel is the mature man's knowledge that meaning can never quite penetrate reality, but that without meaning, reality would disintegrate into the nothingness of inessentiality" (qtd. in Echevarría xi).

Estienne's constant companion, 'Jeanne', further highlights the layering of literary and historical reference foregrounded by the Don Quixote text. She is the legendary Jeanne d'Arc who continues to incite rebellion from beyond the grave: her voice guides and counsels Estienne, acting as his conscience as he develops as a dissident figure. Each of the transtextual references ${ }^{78}$ foregrounds the constructed nature of the text being read while simultaneously alerting the reader to the constructed nature of all versions of reality. Both language and narrative, in these terms, are undermined as reflections of 'reality', in poststructuralist terms. The inclusion of literary and critical material from various sources, and the 'borrowing' of

\footnotetext{
${ }^{78}$ A full examination of transtextuality in Brink's work is outside the scope of this thesis but clearly related to the topics explored. For further discussion regarding Brink's postmodernist response to dominant discourses see his article "Interrogating Silence: New Possibilities Faced by South African Literature".
} 
official and mythological historical narratives points to a concern to both re-write history and re-contextualise it. In this way, 'history' is ultimately re-written with the assistance of a multitude of alternative voices. This inter-weaving of material considered 'fictional' and 'factual' subverts these terms of reference, revealing them as arbitrary designations. Transtextual gesturing undermines the author-ity of any text, demonstrating that both author and text have inextricable ties to alternative authors and texts and so refutes the author-ity associated with authoritative or canonical versions. As Barthes notes in his essay, "The Death of the Author":

[w]e know now that a text is not a line of words releasing a single 'theological' meaning (the 'message' of the Author-God) but a multidimensional space in which a variety of writings, none of them original, blend and clash. The text is a tissue of quotations drawn from the innumerable centres of culture. ("Death" 146)

In these terms, Brink's trans- and paratextual tactics provide a further means of challenging fixed and dominant discourses while simultaneously allowing an ongoing dialogue with other artists and texts.

In the various ways described above, Brink's text denudes the writing process of much of its imperialist impulse and power. The text points to the ways in which narrative may be used as a mode of confession and apology and thus, a means of gaining access to the victims of history. 


\title{
Narrative
}

\author{
"'What is this thing you call a book?" \\ 'It is a man's life"'
}

(Brink Contrary 352).

\begin{abstract}
Although deconstructed as an unreliable depiction of reality, narrative is foregrounded in On the Contrary - as in previous texts - as a marker of identity and identification. While acknowledging that narrative, and the language in which it is phrased, are poor modes of representation they are, problematically, the only means of representation available: the lack which describes the relationship between words and truth is not countered by any more stable access to meaning. Demonstrations of the inadequacy of semiotic systems of representation recur throughout Brink's texts, as do characters who express their frustration at this inadequacy. Such claims raise some questions as to the mediation of reality which are of particular interest in considering the representation of reality in literature. If there is indeed no unmediated access to reality, then how may one calibrate the distance, or difference, between an established version of reality and a competing account? Further, how may various competing versions be judged against each other? Is reality merely conventionalism? In a semiotic system of representation is every account equally truthful, or equally untruthful? Is the dissident account automatically more truthful than that espoused as a categorical truth? Further, what is the value of a relative truth, as opposed to a categorical? Essentially, each of these questions may be reduced to one: how may the value of representations of reality be judged when the mode of representation is flawed? Brink unmasks the construction of truth claims, which suggests that he has some knowledge of what the truth is, or at least some notion of the means by which truth should be judged. Estienne's immersion in the unreal and the real provides opportunity to consider these questions and reflect on discursive and counter-discursive roles and their significance and meaning.
\end{abstract}


Estienne's fascination with the record of experience and his determination to discover truth metaphorically represent an authorial struggle with the same and the frustration which results from entrapment within restrictive modes of representation. As in earlier texts, the protagonist searches for meaning and, in his case, the search is undertaken by means of a series of journeys and a correlative series of narratives. The manner in which the search is linked to narration is revealed in Estienne's rendition of a creation myth, originally told by Rosette (184). Rosette's original myth reflects the poststructuralist concept that words grant access to reality: the original storyteller gives birth to the world and its inhabitants by speaking them into being. The narrative also depicts the ongoing search for meaning - identity and identification - which Brink's characters invariably undertake, and the desire to retum to an idyllic world.

Estienne explains the relationship between narrative and meaning stating, "I have given up trying to explain either others or myself. This is just a story" (4). He implies that words cannot express the self or others and therefore any attempts to describe or make meaning of experience must acknowledge the inevitable disparity between the experience and its representation in language. The suggestion is the fictive form, in its foregrounding of its own mutability and constructions, better reflects experience, because it does not claim to be truth. In Brink's text, Estienne in his role as writer of his own historical narrative - foregrounds the redemptive possibilities of the narrative form, suggesting that, despite the prescriptive nature of language, narrative may also reveal some sense of personal, individual truth(s). His rendition(s) of (personal) history fulfil(s) the understanding of history as argued by Worthington:

The history one tells one's self, through the process of one's memory and facilitated by the memories of others, is a narrative in which moments of the past achieve some kind of interconnection, even coherence. [....] it provides a more or less stable conceptual framework from which to begin to understand the present and anticipate the future. (14-15) 
Estienne's apparently unstable historical narrative or narratives represent an ongoing mediation of the events of his past which contest the static official and clearly censored rendition of official record. Thus, the narrative process enables an otherwise difficult - perhaps impossible - conceptualisation of selfhood in response to prescriptive models, providing a format for reconstruction of identity. ${ }^{79}$

In the larger context of Brink's text, the use of metafictional devices, in particular, demonstrates the avoidance of collective, totalitarian truth claims. Foregrounding the process of fiction-making in texts which employ metafictional devices counters authoritative truth claims by establishing the arbitrary ${ }^{80}$ nature of the selection and depiction of events narrated: thus, the disparity between 'reality' and its narration is highlighted. Estienne's narratives, like those of Brink, are understood as searches for meaning, a means by which to connect with oneself and with others. The imaginative possibilities of narrative also allow a freedom denied in prescriptive, authoritative, fixed or singular records, allowing the narrator freedom to create a specific experience or identity. Estienne notes, "I could literally invent myself through what I chose to tell. I could cancel myself by remaining silent. Or I could create whole multitudes of me through different stories. From that moment I had control over my destiny" (191).

Like Larsson's journals in An Instant in the Wind, a series of 'official' records trace colonial attempts to 'name' and 'tame' the land and its people. These records include Estienne's journal, the sanctioned version of the company's trek into the interior which is increasingly subjected to the censorship of the narrator's commanding officer until Estienne is eventually replaced as company scribe: his personal observations are "not part of the accepted or acceptable truth of the Cape of Good Hope" (27). Estienne's resistance to the prescriptions of officialdom, to colonial propriety, is the first stage in his developing awareness of the injustices and

\footnotetext{
${ }^{79}$ This understanding of narrative will provide background to the contestation of fixed historical truths in chapter eight.
} 
prescriptions of his environment. Initially, he considers their trek "a precarious invincible trickle of civilisation and noble aspirations moving through a dark interior, rewarding it with conscience and history" (18). He soon realises, however, that history and conscience are merely abstractions, framed by, and vulnerable to, the whims of those in power. Consequently, he becomes increasingly resentful of the suppression of his journal records: "this always: below the dull grammar of the daily account, a different course of consciousness. Intimate truths, discoveries, many questions" (36).$^{81}$ Essentially, his impossible epistle is a dissident response to such censorship, an attempt to narrate against the official version: "I am speaking against accepted history $[\ldots]$ which is the only version the world will know" (323). In Estienne's epistle, excerpts from his journal are preceded by accounts of his experiences in which his thoughts and feelings - rather than mere observation - are included. Estienne's 'version' is ostensibly a fuller - if not a full - account than that offered by the official record and represents his imperative "To interfere with history" (229). As I have intimated above, this 'interference' is also relevant to an understanding of contemporary history. Again, the cultural dialogue in which Brink's texts are arguably engaged encompasses a critique of the bias and prescriptive nature of both past and present historical narratives. At the time of publication, in a nation undergoing a crisis of authority - in terms of the impending first South African democratic elections and the alteration in authority that would certainly entail - the consideration of how and by whom history will be narrated is particularly significant. In its blend of historical subject-matter and metafictional self-reflexivity, the text fulfils Linda Hutcheon's criteria of historiographic metafiction, which transgresses fictional and non-fictional boundaries and establishes the discursive nature of the narrated world (summarised in Jacobs 40).

\footnotetext{
${ }^{80}$ The claims are arbitrary in the sense that their justification is premised on a set of accepted values which may easily be replaced by any other, rather than arbitrary in the sense that they have not been carefully chosen, implemented and maintained in order to fulfil a specific purpose.

${ }^{81}$ This demonstration of the manner in which the narration of history is specifically intentionalist is examined in Paul Carter's Living in a New Country: History, Travelling and Language, and will be further addressed in chapter eight, which is dedicated to historiographic issues.
} 
If representation is a failed approach to the 'real' then what is the alternative? Estienne's recognition of the flawed nature of semiotic systems of representation is correlated to his 'madness': in this respect, insanity is freedom from traditional cognitive systems. Further, Estienne suggests that the land itself, its contours and its landmarks are a "visible language", they are the reality usually (inadequately) expressed in semiotic terms (356). The rocks and mountains he observes in the last days of his journey represent the narrative creations of the original storyteller and are a direct means by which one may connect with the world (356-7). The text suggests that physical natural objects are the only reality, a reality immune to social discourses and human manipulation and operating beyond prejudice, politics and social constructions. They are the only (impractical) replacement offered to the flawed semiotic systems by which the world is traditionally narrated. These claims are revelatory in that they provide some answer to the question of value judgment, the calibration of truth discussed earlier. The depiction of the "original storyteller" suggests perfection of both narration and narrative, implying that she has access to the 'real'. Her access to the truth provides an ideal by which all other truth claims may be calibrated.

Each of the problems of representation explicated by Estienne relate also to the text's author, Brink himself. He too is confined by the inadequacies of language as a mode of representation. Likewise, he is defined by the knowledge that if language creates reality, he too is a construct, a creation of words. Recognition of these two delimiting factors has significant consequences for the text, its author and its reader. Each is bound by a mode of representation which is inadequate and yet is the only means available. Acknowledgement that oneself and one's world are reflected by a limited system of codes has a crucial effect on the relationship between text, writer and reader. The reader, like the author and the text, undertakes a search for meaning with the prior knowledge that this journey towards Truth must fail. There remains, however, some notion of provisional truth. Arguably, if provisional truths exist, then the pursuit of Truth is still valid and worthwhile. Again, the journey 
towards an ideal is posited as more crucial than the end goal - indeed, the end goal is unreachable.

\section{Journeying into the Interior}

\section{"Nothing like a joumey into the interior of a savage land} to separate the true from the false"

(Brink Contrary 13).

Journeying and the search for truth are primary motifs both in Brink's oeuvre and in this text. Each represents the process of exploration. The notion of a journey towards an impossible destination or goal speaks of the problems of representation, identity and truth described above. The journey represents an immersion in the provisional truths of which I have spoken, a means by which one may gain some understanding of the world and of one's place in it, ${ }^{82}$ while acknowledging the limitations of this 'knowledge'. In twentieth century fiction, the journeying subject purportedly undergoes a process of self-interrogation, challenging established beliefs and arriving at some conclusion/destination. ${ }^{83}$ In Brink's work, however, it is in the journey itself that some sense of fulfilment is found. Crucially, the conclusion or destination - in a journey, as in narrative - represents a foreclosure of alternative possibilities and thus refutes the palimpsest of competing accounts foregrounded in this metafictional text. The value in the journeying process is, therefore, in the arguable freedom of possibility which that process allows.

The motif of a journey towards an impossible destination or goal is also reflected in symbolism related to acts of reading and writing. Estienne's quest for Rosette enacts a search for meaning: "I write myself into another quest for you" (349). The processes of reading and writing mirror those of journeying just as written

\footnotetext{
${ }^{82}$ This claim reflects a modernist sensibility in which one exists in a Godless universe, with traditional structures damaged, and the only means of redemption is in self-knowledge. The problem is that this claim provides no justification for the ostensible link between self-knowledge and redemption.

${ }^{83}$ Joseph Conrad's Heart of Darkness is paradigmatic.
} 
accounts reflect the physical experience. In these terms, writing is described as a journey of discovery, rather than as the achievement of a fixed solution or conclusion: it is the process of writing or of reading which is emphasised, rather than the conclusion. The inclusion of acts of reading and of writing in the text places the characters as both readers and interpreters. In this way, the characters embody the reader function and allow a theoretical examination of interpretative acts. Thus, the relationships between the text and the reader and between the author and the reader are foregrounded. Ommundsen notes that such examination is an attempt to produce the appropriate conditions for the text's reception by the reader (65) and that any act of interpretation may represent the act of reading (66). The text thus manipulates the reader's response by encouraging a certain mode of reading. This 'guided' reading stance is crucial in order to deflect the problems associated with the requirements of a metafictional text, problems I have already outlined. The metafictional text's dependency on a certain type of "interpreting" reader and reception is therefore addressed: s/he is coerced - arguably, forced - to adopt the text's dissident attitude.

As I suggested in chapter two, various censorial practices delimit the imaginative realm in South Africa and are clearly problematic for the nation's literary artists. Both colonial and apartheid South Africa represented lands in which singular and fixed narratives of reality refuted imagination and myth. In apartheid South Africa, the material available to literary artists was clearly circumscribed by a prohibitive state: vast areas of the literary realm were deemed taboo. Therefore, artists were faced with a dearth of practical ways in which to address what (arguably) constituted the central issues of their era. Despite the constraints placed on artistic production, Brink managed to write of and to his specific political and social environment, adopting a dissident position against the prescriptive apartheid state. In the novel under discussion, for example, the text focuses on an historical era, in which the nation and its colonial inhabitants were 'under construction', in order to address issues of authority, identity, identification and truth relevant in a contemporary context. The anxiety of South African authorship represents a lament for the possibilities denied by a prohibitive state, but also reinforcement of the 
(marginal) existence of these possibilities. In these terms, Brink's text is a restorative project, like many of his others, in which the imaginative possibilities of the South African environment are revealed and endorsed. On the Contrary is not a plea to immerse oneself in the 'insanity' of the protagonist, but rather exaggerates the imaginative realm by the use of magic realist and metafictional devices in order to promote the possibility - indeed, the existence and worth - of alternative narratives.

On the Contrary engages with some primary issues in regard to both the South African context and the role of the writer. The establishment of a colonial nation in $18^{\text {th }}$ century South Africa resonates in a contemporary context. The negotiation of authority and social structures in the text provides commentary on a contemporary nation undergoing a renegotiation of the same, just a year prior to the first South African democratic elections. In each 'text' - that of the novel and of contemporary South African history - the challenge to authority and the search for individual identity and identification is central. Simultaneously, the novel engages with issues of narration and of narrative's relationship to truth. In this sense, the text, its implied and actual authors, participate in an ongoing dialogue surrounding postmodernist, poststructuralist and metafictional disruptions of historical meaning. It speaks of the paradoxical position of the writer who attempts to represent reality while acknowledging the impossibility of this act. Further, it describes the frustration of a writer forced to use an inadequate mode of representation, that of language. It is also concerned with the loss of identity and of authority associated with the refutation of metanarratives. In response to problems and paradoxes such as these, the text posits narrative creation as a restorative. The processes of writing and of reading, it is suggested, like those of journeying, are means by which one may gain some sense of identity and belonging. The end goal or destination is both impossible and undesirable, as it represents the foreclosure of alternative possibilities, a prescription of identity and identification. Instead, the journeying and narrative processes each allow a myriad of alternative possibilities and thus represent the freedom disallowed by prescriptive models. Therefore, the text suggests, it is in the act of reading or of writing, the imagining of the possibilities of selfhood and identification, that one 
gains some sense of personal and collective meaning beyond the prescriptive and static model demanded in an oppressive system. On the Contrary continues the cultural conversation begun in earlier texts, critiquing the status quo of the prescriptive and prohibitive apartheid state, the foundational truth claims on which these prescriptions depend, and encouraging the reader to undertake similar critique. On the Contrary, however, differs from the texts discussed previously in that this critique is both thematic and, most blatantly, structural: the technical and formatting devices of metafiction are utilised in order to strengthen thematic concerns. 


\title{
CHAPTER 7
}

\section{States of Emergency in}

States of Emergency

\author{
"In your own country \\ people are living in a permanent state of siege" \\ (Brink Wall 430).
}


One of the epigraphs which precedes States of Emergency reads:

The year which ends at midnight tonight has been so full of violence and sadness that many will feel that the sooner it is forgotten the better. Yet 1985 was a watershed year and before its manifold horrors are thrust out of mind it would be as well to reflect on the significance of what has happened. (Cape Times 31 December 1985, n. pag. qtd. n. pag.)

Brink undertakes this reflection in a text set firmly in one of the South African states of emergency of the $1980 \mathrm{~s}^{84}$ And yet his text also purports to consist of "[n]otes towards a love story" (1). The manner in which love and politics are both opposed and connected is the framework which binds these 'notes' together. The text is a commentary on the role of the artist in a censorial and prohibitive environment - a context discussed in chapter two. Using the work of Fugard and his dictum - "the only safe place is inside a story" (qtd. 29) - as inspiration, Brink's novel explores the impossibility of separating the personal from the social and story from history. The text is further example of Brink's use of metafictional devices to reflect a particular historical environment; it also demonstrates the consequent problems for the literary artist. This is the focus of the examination which follows.

South African State of Emergency legislation reinforced the security legislation already in place by allowing repressive measures to be taken openly and unchallenged by either the courts or the public. Commentators A. S. Matthews and R. C. Albino claim that the security laws "brought about a situation in which it is no longer possible to distinguish between the preservation of order and the preservation of the power of the ruling party and between opposition and subversion" (Dugard 121). ${ }^{85}$ Merrett concurs:

South Africa has existed in a permanent State of Emergency since 1960, so draconian have been the provisions of non-Emergency security legislation.

\footnotetext{
${ }^{84}$ Notably, States of Emergency is the only one of Brink's novels not to be published in Afrikaans or in South Africa; the novel was first published in Great Britain in 1988. The decisions to publish abroad and in languages other than the author's native tongue further suggest the censorial conditions of the era.

${ }^{85}$ In 1994, Merrett noted that the interim constitution still allowed the government to declare a State of Emergency at any time (209).
} 
To some extent, the Emergencies from 1985 to the present [1994] have related more to a psychological requirement on the part of the regime than the need for measures to deal with insurrection. Thus, some writers refer to this period as the Emergency of the State. (208-9)

Therefore, when Brink examines a State of Emergency in his novel States of Emergency, he investigates certain aspects of his everyday environment in an intensified context. In these terms, the text examines the central tenets of the apartheid milieu.

The period in which the text is set was one of uncertainty and tension. White South Africans began to glimpse a future in which their privilege would be revoked, and black South Africans likewise envisioned a renegotiation of control, of authority. The overwhelming tone of this text is, therefore, one of imminent apocalypse, of "an entire familiar order [...] passing away" (214). This tension and anxiety is reflected by the tone of the text: in both content and form, there is a mood of hesitancy, a lack of certainty. Largely, this is a result of the implied author/narrator's challenge to fixity, the refusal to conclude. It is also, however, a reflection of the political uncertainty of the era in which Brink was writing. In these terms, the text's plot may be hesitant, and yet its reflection of the social and political milieu is clear.

Clearly, the titular phrase reflects the state-imposed enforcement of the era in which the text is set - and the tension which results. In literal terms, the declaration of a State of Emergency represents the culmination of authoritarian measures to suppress protests such as those of the Soweto Riots of 1976. In his descriptive record of the era, Brink once again challenges the censorial and prescriptive environment in which he writes. More importantly for this discussion, however, the title also refers to a period of literary emergence which parallels the social. This form of emergence is linked to both the text and its author, Brink. The text is clearly an "emergent text" (19) which never coalesces into a definitive, complete whole. Further, Brink's use of metafictional techniques is essentially an authorial emergence, a technical re-birth in which he develops new forms to communicate his themes. This re-negotiation of 
literary form parallels his now well-established experimentation with traditionally 'taboo' subject matter and develops the experimentation begun with the Sestigers. Progressing from challenges to the authoritarian largely based on content, Brink now engages with the communication of that content, reformulating the means by which the author and the reader engage. A titular echo also pervades this experimentation: his authorial refusal to categorise and conclude is suggested in a play on the word 'emergency' - Brink's text 'merges' 'real' and 'unreal'. The sense of emergence suggested in the title is therefore one of both progressive and creative acts: there is a significant movement during this period in both the response to despotism and also to the authority of traditional literary forms.

Essentially, States of Emergency is an impressionistic text, consisting of a series of notes and fragmentary narratives. These segments never coalesce into the novel intended by the unnamed implied author/narrator. In a manner reminiscent of Ben Du Toit's posted package of notes and documents (A Dry White Season), this narrative begins with an unsolicited manuscript, sent to the implied author/narrator by a talented writer named Jane Ferguson. Her novella, A Sense of Occasion, is a tragic love story in which the abandoned heroine commits suicide (15). Attempts to have the manuscript published on her behalf are met with complaints concerning its insubstantiality; reputedly, it is too short to be published alone and requires the addition of a political slant to arouse the interest of audiences whose attentions are focussed on South African politics. As States of Emergency progresses, the publishers' recommendations are lent ironic significance: following Jane's own suicide, it is revealed that her manuscript is based on her love affair with the now deceased South African activist, Chris de Villiers (39). Jane's narrative and that of her novella - the embedded text - are intertwined with a variety of episodic narratives under the construction of the implied author/narrator of the surrounding text. He outlines events concerning Philip Malan, the text's protagonist, a middle-aged Afrikaner university professor. Philip's adulterous affair with a postgraduate student, Melissa Lotman, is the ostensible basis for this 'love story', and yet the fragmentary notes of the implied author/narrator also depict the violence, destruction and despair 
of South Africa during the State of Emergency. Simultaneously, Brink provides details so similar to his own biographical reality that the distinction between himself, as author of the text, and the implied author/narrator of its various narratives, is continually undermined. Further, there is a blurring between the unnamed authorimplied author/narrator and his fictional protagonist. As I will argue, the disruptions of both form and narration evident in this text are crucial in their reflection of Brink's thematic concerns.

\section{Writing}

"Winston Smith: "The act of marking the paper was the decisive one"" (Brink States 201).

As in much of Brink's literature, this text is concerned with the act of writing and employs a writer/narrator in the text as the means by which to explore this process. The multiple narrative threads of the text represent a series of attempts to narrate beyond, against, and of, the writer's particular environment. In these terms, the threads reflect the question which pervades the text, the query as to how one can write in such an unjust situation. This question is re-framed as the text progresses. The implied author/narrator complains,

[f]or years now I have been toying with the idea of writing a simple love story. Something like the perfect little novella she [Jane] has written, uncluttered by any 'political dimension' of the kind demanded of her by the agents and publishers. I don't know what has restrained me all the time. A fear of escapism, of 'opting out', perhaps? As if a love story might imply some form of betrayal towards the great current of history sweeping past me: this torn and plundered country, this goddamned time? Does one not have a weightier 'obligation' - as a human being, as a citizen, as a writer - towards what is happening around one? Barthes describes 'love' as 'a socially irresponsible word' (5). 
He ponders, as Brink does in his essays, whether it is a socially irresponsible act to turn from a politically ravaged milieu and write instead about subjects such as happiness and romantic fulfilment. This act, both the implied author/narrator and Brink suggest, would be a betrayal. The implied author/narrator also suggests that the fate of Jane's novella is indicative of the futility of such creative acts (6). In effect, Brink's text is an experimentation of literary freedom, testing the waters as to what content is acceptable - acceptable not in terms of the censorial environment, but in the context of his own sense of artistic responsibility. The implied author/narrator proposes "to test the extent of my own freedom - that freedom which may involve the choice to write a love story even (or especially?) when something else appears to be demanded of me (by whom, or what?). The freedom to follow a story wherever it may lead me" (6).

The text also asks how one can turn away from the violence and brutality of the nation, to put pen to paper at all - is that not a misuse of one's artistic energies? This concern is one widely argued in activist circles: do (dissident) artists succeed in challenging oppression, through their art, or is the act instead an avoidance of physical resistance? The implied author/narrator frequently abandons his writing when the realities of the South African troubles - often represented by the figure of Milton Thaya - intrude into his creative space; he claims, "it often seems like an act of betrayal to shut out the outside world" (106). Later, after Milton's death, he complains, "[h]ow the hell can I go on? I haven't slept a wink all night. How could I? Milton Thaya is dead. My friend - that ebullient, irrepressible man - is dead. And I'm supposed to go on writing about love" (238). Clearly, the completion of a love story is impossible under these circumstances: it will remain a series of notes, until the urgencies of the writer's environment are quelled.

\section{The Artist and Society}

"Every work is a meeting point between writer and reader"

(Brink "Censorship and the Author" 21). 
While the text is an examination of the relationship between the artist and society, ${ }^{86}$ a musing on the responsibility of the writer and a consideration of her/his lack of freedom in a censorial milieu, concurrently the reader's relationship with the text is emphasised. States of Emergency moves between the experiences of the implied author/narrator, the (various) imagined experiences of his characters, Jane's narrative and those of her characters. The result is a blurring of distinctions between author and text which undermines author, author-ity and authoritarianism. In this context, the reader is arguably employed as the final arbiter of meaning of a largely postmodernist text; s/he is the last in the line of interpreters of the text. In this respect, readers enter "into a kind of collaborative dialogue with the fiction, coauthors in a communal act of creation" (Jacobs 40). As I have suggested, the success of this relationship depends on a certain type of reader and a particular mode of reading.

Despite Brink's use of many self-reflexive devices in this text and his depiction of a postmodernist-styled deferral of truth, Brink's relationship with postmodernism is problematic. Postmodernist understanding is outlined in Barthes' notion of 'the death of the author': "the text is henceforth made and read in such a way that at all its levels the author is absent" ("Death" 145). Ommundsen adds that, in Barthes' formulation, "the demise of the author signal[s] the birth of the reader as the sole arbiter of meaning" (69). ${ }^{87}$ Postmodernist authors recognise that their authority over the meaning of the text is limited and that this meaning will be, at least in part, construed by the reader. In earlier discussion, I suggested that Brink's texts appear to operate in this way, creating a palimpsest of alternative narratives and

\footnotetext{
${ }^{86}$ This relationship will be examined in relation to Brink's texts in chapter ten.

${ }^{87}$ The critique raised against Barthes' theory and this suggested reader-position is one of essentialism. Rather than the traditional essentialist position of the author, in which meaning is inherent in the text and traceable to an author's intentions, in Barthes' model the position is inverted to reveal the reader as the primary source of meaning. However, the reader is always constrained by the text, as it is indelibly printed on the page, and thus cannot be the sole arbiter of meaning. The relationship is rather a dialectic between reader and (through the medium of the text) the author, in which each contributes to the overall meaning of the work and its effect on, and relevance to, the reader.
} 
encouraging the reader to choose a version. However, in each of his texts, Brink also maintains an authoritative stance, guiding his reader to a certain mode of reading and response. He attempts to manipulate or modulate the reader by using clues such as implied author/narratorial asides and the encouragement of reader sympathy to prompt a certain (often moralistic) engagement with the text and its themes. $\mathrm{He}$ ensures that a certain amount of information is provided regarding his characters, so that the reader may make moral judgements on which the credibility of their narratives may be judged. The reader, therefore, is technically given the freedom to interpret, but is guided in this interpretation; judgement is simultaneously placed with the reader and withheld. ${ }^{88}$ Not only is the reader's postmodernist contribution to the meaning of the text undermined, but also postmodernism's "commitment to difference" (Mansfield 184) is reduced to a hierarchical structure based on moral values.

\section{The Ongoing Search for Meaning or Truth}

“... [myth's] ceaseless efforts to transcend the mere facts of things in order to arrive at what may be termed their truth"

(Brink, "Imagining the Real" 215).

The failed narrative of the text - a love story which is never concluded - is centrally an attempt by the implied author/narrator to understand. His search for meaning or truth is a form of catharsis similar to Jane's. She asks, "[f]or how many hours have I now been sitting here, writing, hoping that by committing it to paper I can bring myself to understand what happened, is happening?" (145). I contend that this is (partly) Brink's motivation also: this text is not merely the reportage or testimony of A Dry White Season, but also represents both personal and communal catharsis, a processing of issues, both individually and collectively. The searches for meaning undertaken in this text and in Brink's oeuvre as a whole are indicative of a

\footnotetext{
${ }^{88}$ The danger in attempting to guide reader response lies in the assumption that a certain type of reader will engage with the text. Necessarily, an implied, or likely reader is addressed and, in Brink's case,
} 
parallel search as a nation. In this sense, the text continues the 'cultural conversation' with which I have aligned Brink's work: he is both speaking to, and of, his environment, while soliciting some form of response from his reader.

However, the love story is not merely a means by which the political may be contrasted: it also fulfils another function. Envisaged as a search, a quest for meaning - of both self and other - love metaphorically traces the search for meaning undertaken in both this text and Brink's oeuvre as a whole. In States of Emergency, the implied author/narrator asks

What is at issue in a love story? In languages like Spanish and Portuguese the word for 'to love' - querer (besides amar of course) - is related to the concept 'to want' (cf. in English 'acquire', 'require'). Which would tally with our ordinary, superficial experience of love as a personal form of imperialism. But should one not, in addition, acknowledge in it some relation to words like 'quest' or 'request'? Love as ceaseless interrogation, as a search without end - not necessarily moving towards a Promised Land where sooner or later the pilgrim arrives, but a voyage which, in search of sense, demonstrates only the sense of search (i.e. the very fact that it is a process, an experience of being in motion, without any clearly defined point of departure or arrival). (47)

In terms similar to those of On the Contrary in which the journey and the processes of reading and writing are emphasised, rather than the end goal or destination, here the implied author/narrator re-conceptualises love, not merely as a form of conquest of another, but also as an ongoing search. ${ }^{89}$ In this context, the text's resistance to beginnings and endings - to conclusion - is mirrored and reinforced by Brink's decision to frame these concerns in a love story. The "ceaseless interrogation" by which love is defined is also the imperative of the text and author: each questions self and other, undertaking the quest for meaning. This 'quest' represents a willingness to immerse oneself in the relationship between self and other and to investigate the manner in which this interrelation operates. Meaning, in this respect, is under 
revision: any Truth - as defined as fixed and singular - is set aside in favour of the process of discovery. The labels of both self and other are under continual renegotiation while this quest is in progress. The implication is that a greater sense - of both oneself and others - is possible when one rejects the conventional epistemological frameworks by which such knowledge is learnt, and instead permits a direct engagement with the object of inquiry. ${ }^{90}$ In terms of the text, this process is an attempt to find means of articulation beyond those allowed in an oppressive and censorial milieu.

\section{Fore-word and Pre-text}

"At this stage I prefer to leave the options open"

(Brink States 19).

Experimentation in terms of form is the central means by which this quest is undertaken. Developing an approach first used in Looking on Darkness, States of Emergency is framed by destabilising devices. Like Joseph's impossible 'disappearing' text, this text is explicitly framed by both an account of its construction and its deconstruction. In conventional styles of textual construction, the text is rounded and resolved; this style panders to the reader's desire for coherence and conclusion. In contrast, texts such as States of Emergency use destabilising devices to alter the reader's engagement with the text; $s /$ he is continually prompted to reassess the reading role and its implications. A refusal of textual certainty consistently counters the accepted conventions of the novel genre: the textual undermining of truth, in terms of plot, is paralleled by a similar deconstruction of conventional form. The traditional chapter divisions of the novel form are absent: rather, the text remains a series of notes, suggesting a manuscript under construction. Simultaneously, the appearance of the text on the page suggests 'stuttering' speech,

${ }^{89}$ This distinction is important in relation to earlier discussion centred on the imperialist tendencies of self/other interrelations (chapter three). 
the belaboured narration representing the struggle to find voice and audience in the face of a prohibitive and censorial environment. Whether these episodic pieces of narrative are fragmentary, or endlessly connected, is for the reader to determine. The experience of a search for meaning, for a means by which to communicate under censorial and oppressive conditions, is shared by the reader. In this way, the text represents the undermining of traditions of order and categorisation, resisting classification, beginnings, endings and conclusion, as does the text's favouring of alternate narratives and the blurring between them. The origination and conclusion of the text's love narrative, for example, are constantly renegotiated in a textual interplay which resists fixity. The text appears to be a series of tentative gestures towards narrative(s), rather than narrative itself. The initial meeting between the two protagonists, Philip and Melissa, is representative, manifested in several different guises, each of which recurs and echoes throughout the text (41). In this imaginative construction, the reader is complicit, unable to extricate her/himself from the creative processes of the author and forced to adopt an analytical role; s/he is urged to engage in the same dissident role of the author, undermining textual author-ity.

The text's resistance to containment also includes a disruption of linear chronology and of spatial stability. The experiences of past and present, and of 'real' and 'fictive' characters are blurred, as are the heterocosms these characters inhabit. Various events are re-membered or re-envisaged by different characters in a collapse of the different parallel narratives. A red mug, which recurs throughout the text, provides an example. Each of the characters associated with this object appears to have an instinctive connection to it. In her diary, Jane describes how, when weeding the gravestones, she suddenly had a desire to dig. She is rewarded with the discovery of "what looked like the rim of a red plastic mug", a relic which she subsequently returns to the ground (79-80). Later, the implied author/narrator remembers an incident in which, during her first visit to the sea, his young daughter began to cry, demanding her "little red cup". Inconsolable, the child moans for hours until they

${ }^{90}$ There are, of course, problems with the assumption that one can operate outside of one's particular
epistemology. However this is not an examination of the merits of the underlying arguments; rather it 
take her to the beach where she uncovers 'her' mug in the sand (208). Further echoes of these two events recur, lending a surreal atmosphere to the text. While it is arguably a common occurrence for writers to use elements of their own experiences and those of others in their works, there is a transparency in the way this is done which operates deconstructively, forcing on the reader an awareness of her/his own conventional expectations of fictional ontologies. The reader has no verifiable version to cling to, no fixed point of reference by which the 'real' may be judged. This distuption of reader certainty is a metafictional exposure of the processes of implied author/narratorial construction which simultaneously critiques fixed narratives and espoused truths. Instead, the reader is exposed to a number of alternate possibilities. As Melissa notes,

One must go further than Saussure. In his paradigmatic category each word in the sentence 'displaces' all other possibilities that might have operated there. But we tend to forget that this displacement is never absolute. It's not just either/or. All the others resound in the one which actually materializes, like vibrating strings. The totality of language vibrates in every word [...] It is a terribly dangerous game in which nothing is ever ambiguous or final or 'stated'. (130)

In one sense, the format of the text is unfulfilling, in that its resistance to conclusion and certainty leaves the reader largely dissatisfied. In contrast to a usual novelistic format, there is no single conclusion, and also a resistance to prioritisation of one version over another. The multiple narrative threads are not brought together except in a blurring of alternatives, a crossover of different possibilities which further reinforces the resistance to categorisation and conclusion. Often, this repetition of various images and incidents also constitutes a blurring of heterocosmic boundaries. The various milieus of the text, those of the author Brink, the implied author/narrator and putative author, Philip, Jane Ferguson and of her fictional lovers coalesce into one: there is the sense that nothing is 'real' or 'unreal', but all is constructed.

is a consideration of the ways in which Brink meditates on these through specific fictions. 
The implied author/narrator demonstrates a resistance to beginnings, in particular. He suggests that they are fascinating due to their inherent definitive nature: a beginning, he argues - the moment when the writer places the first words on the page - is essentially the moment when alternate possibilities are foreclosed (although this goes directly against the 'resonance' model of language that Melissa suggests above). This is one of the central problems of the postmodernist text which ostensibly favours multiplicity while remaining entrapped in modes of representation which are inherently delimited. Further, the postmodernist text can employ only a fixed number of alternatives, a limitation which denies its intent to demonstrate the limitless possibilities available. Brink's implied author/narrator suggests that the foreclosure of other options inherent in any beginning carries responsibility. Narrative holds the possibilities of both fixity and fluidity, the elements of both authoritarianism and the freedom of multiple alternate versions. The narrative of the conqueror, the authoritarian, the oppressor, may claim the status of truth, denying alternatives. It may also, as the implied author/narrator of this text suggests, close off possibilities: all beginnings are acts of exclusivity, in which a myriad of alternate possibilities are ignored, refused or silenced. The implied author/narrator explains, "[t]hat is the danger intrinsic to the story-telling act: having committed oneself to it, there is no turning back. Which is why I still insist that this is only a preliminary exploration, a testing of possibilities. I have not yet undertaken anything" (65), "[w] hat I have done so far is no more than fore-word, pre-text: isolated moments, episodes, character sketches, intuitions, trial runs" (104). The implied author/narrator is clearly both fascinated by, and wary of, beginnings because they inevitably lead to endings: the fatalism and finality of this fact appears to concern him (17). ${ }^{91}$ This drive towards conclusion is exemplified in the very form by which the conventional love story is framed: the romance novel, he notes, "creates its own set of expectations: namely of a certain consistency, a beginning, a middle, and an end, a centripetal structure" (103). Resisting these conventions, he claims, "There can be no

\footnotetext{
${ }^{91}$ Philip's musings on endings also prompt him to consider the reaction against such fatalism. He suggests, "[p]erhaps our most profound consciousness is this sense of an ending. Perhaps our most basic drives are those directed towards countering, or negating, or rebelling against it. Art, love, work,
} 
end to what has had no beginning. I find myself back where I started. [.... Novels have ends, stories run on in everlasting spirals, circles, rings" (243). The implied author/narrator suggests his text is not a novel, but is rather defined as a 'story' which resists closure and fixity. In these terms, the text is politically dissident in its refusal to be confined by conventional and preclusive definitions. There is a tension here between the (feared) textual determinism signalled by the fear of beginnings and the poststructuralist understanding of the indeterminacy of language which seems unresolved in Brink's text.

The implied author/narrator's prevarication is paralleled by that of the South African environment. Describing the beginning of the State of Emergency, he notes that what had happened from the start of the calendar year until 21 March, when the Emergency was enforced, "can now be seen as mere attempts of history at finding a starting point, a testing of paradigms, a playing with limitless options" (23). Prior to the declaration, a myriad of possible futures for the nation existed; once the State of Emergency was declared, however, these possibilities were drastically reduced, and the course of history inevitably determined. Like a narrative, once a beginning has been articulated, the possibilities for conclusion are consequently delimited. The implication of this particular conception of historical narrative for the South African

emate of the State of Emergency environment - in which ed is barely contained by that of the oppressor - appears violent conclusion. The result, it appears, will be one of ne victory of the oppressor over the oppressed or, more r to avoid a purportedly predetermined outcome, a return the foreclosure of alternate possibilities is considered each of them ends up by confirming what it has set out to deny" (17nanner in which certain historical decisions and moments determine is interesting in respect to his own work. Perhaps his unwillingness to s problems may be viewed as an avoidance of responsibility for the on' and the course of action which may follow. context is crucial. The sta the violence of the oppres destined to be brought to very few options, either likely, the reverse. In ord to the conditions prior to nec essary. ${ }^{92}$

religion, language, sex. Even if 18).

${ }^{92}$ Brink's understanding of the the subsequent course of history claim a 'solution' to the nation' consequences of any such "soluti 
The inconclusivity and fragmentation of the implied author/narrator's notes are symptomatic of an environment which denies articulation. Simultaneously, they also represent a refusal on the part of Brink - the ultimate author - to accept the foreclosure of that environment. The text's resistance to conclusion is essentially a refusal to define, to grant meaning. As is common in Brink's oeuvre, this refusal is couched in linguistic terms. The implied author/narrator notes,

[p]erhaps our traditional confidence in syntactical wholes rounded off with full stops is misplaced: who knows but that language, far from resembling a train consisting of a row of coaches, may not really be an unbroken flow, like a river, in which for pure convenience we artificially isolate moments in order to grasp at meanings drifting by like bits of flotsam and jetsam on the tide? To regard a sentence (or a narrative, of which the sentence is but an image) as a product, rather than as a continuous, forever unfinished process, may be as dangerous an illusion as to conceive of life itself as a satisfying syntactic encapsulation of sense. (47)

This metaphorical examination of the relationship between the articulation of experience and the meaning derived from it is a central concern in Brink's work. His suggestion is that any meaning is given momentary specification despite operating in a type of continuum. The implication is that authoritarian and prescriptive versions of reality are arbitrarily derived, or constructed, and fixed: they are therefore no more indicative of reality than any other alternate version. Here, Brink appears to subscribe to the popular notion that by challenging authority, access is granted to a range of alternate possibilities. He suggests that it is a redemptive act to destabilise Truth and to foreground the freedom which alternate options ostensibly allow. $\mathrm{He}$ establishes truth as provisional and highlights instead reciprocal truths. In these terms, subjectivity is not countered by objectivity, but rather intersubjectivity. Brink suggests that meaning is, more accurately, fluid, resistant to fixity and absolutism. This deconstruction of authoritarian truth is a development of the issues explored in earlier texts. In The Ambassador, Brink examines the personal and collective desire to find meaning. In Looking on Darkness, this search for meaning is more forcefully articulated, represented by a renegotiation of prescriptive identifying terms such as 
self and other: the search is for identification beyond the confines of authoritarianism and the acceptable, stultifying image this demands.

There are, however, problems in countering one fixed and singular Truth with a range of provisional truths. Brink demonstrates the invalidity of claims to objective truth, suggesting alternatives, but his own narratives are also inevitably limited by the medium in which they are voiced. Any range of alternate options he offers is inevitably defined and confined within the limited conventions of the text. His offerings are not, therefore, representative of the myriad of alternate and provisional truths available, but rather a selection, a finite number of possibilities. Further, one must attend to the conditions by which the rhetoric of truth sounds compelling in any given situation. While Brink envisages the destabilisation of fixed Truth as a celebration of alternate truths, he does not grapple with one of the central problems with this conception. A challenge to one set of frameworks leads to an awareness of frameworks also being at work in all of the various alternatives.

\title{
Authorial/Authoritarian Control
}

\author{
"What is the conviction about the authority of a text \\ if not a confession of faith in an author? \\ A good old-fashioned naturalistic God, \\ present everywhere but nowhere visible?"
}

(Brink States 26).

Each of the constructions and deconstructions of the text speaks to Brink's central exploration of author-ity. In the text, there is constant acknowledgement of the process by which narrative truth is constructed, and a consequent deconstruction of that truth. The implied author/narrator's manipulation of events is readily apparent. While Melissa and Philip are in the throes of sexual intercourse, for example, the implied author/narrator notes "[t]his is the moment I shall choose perversely - to intervene in their story. With diabolic design I cause the telephone 
beside the bed to ring" (34). His depiction of their shock at the interruption foregrounds the relationship between author(s) and text and encourages its examination. Further, in a footnote, he asks, "[h]ow will he ever find out that it was I who rang? What would he have said if he had indeed picked up the telephone? What would $I$ have said?" (35). The 'reality' or substantiality of the characters was previously undermined by the implied author/narrator's exposure of the methods of their construction. Here, however, the characters are seemingly granted a 'life' of their own, in the suggestion that they will react to the implied author/narrator's actions - that they may respond, independently. While such devices may appear to collapse the ontological levels of the text, they do not: the implied author/narrator retains the power to imagine his characters' (and his own) conversation should they have answered the phone call and thus, the text here merely draws attention to the process of construction, rather than dismantling it. ${ }^{93}$ There is a sense of Brink writing of the implied author/narrator, and of a further author writing Brink into his heterocosm in an endless chain of narrative construction. To some extent, this layering of authorial levels counters the manner in which the implied author/narrator correlates to a God-like figure with the power to both create and destroy. Authorial/implied author/narratorial intrusion of the kind demonstrated here is recurrent, a constant reminder of the implied author/narrator's manipulation of the text and its components $(63,65)$. Also evident are the various implied author/narratorial layers of the text in which the distinctions between the implied author/narrator and his characters, and those of Jane are constantly blurred. This layering of author-ity acts as a constant reminder of the construction and manipulation of experience and the reader bears witness to the construction process. In this way, the text's deconstructive tendencies initiate the same processes in the reader: s/he is sensitised to the construction and manipulation of experience by author-ity. In the context of South African politics, the challenge is again posited against the authoritarianism of oppressive regimes such as that of apartheid, most

\footnotetext{
${ }^{93}$ Jorge Luis Borges asks why does it bother us as readers that Don Quixote be a reader of Quixote and Hamlet a spectator of Hamlet? He responds to his own question, stating, "these inversions suggest that if the characters of a fictional work can be readers or spectators, we, its reader or spectators, can be fictitious" (n. pag. qtd. in Patricia Waugh 127).
} 
specifically envisaged in this text in the State of Emergency. Thus, the reader is encouraged to deconstruct the truth prescribed by the authoritarian state, to mirror the metafictional deconstruction undertaken in this text. Any claim concerning the disintegration of ontological boundaries is simply a means by which convention is broken. Notably, this type of frame-breaking is initially radical, shocking the reader; ultimately, however, it in turn becomes conventional.

The layers of author-ity are further disrupted by the implied author/narrator's commentary on the text. The critical interpretation of the text as it is written - not merely an exposure of the processes of writing but a commentary on the viability, worth and effect of that writing - is a masquerade in which the implied author/narrator adopts the role of critic. This adoption of a different stance in relation to the text further foregrounds the textuality of the novel and its constructed nature, while commenting on this process from another level of interpretation. At various times, the implied author/narrator occupies the role of the implied author/narrator and also that of critic and thus, he is able to foreground his simultaneous construction and deconstruction of the text.

Brink's imperative is not merely deconstructive, however, but also reconstructive. Just as narrative may be fixed and preclusive, it may also be used as a means by which to recover some of the stories disallowed by previous 'texts' (whether verbally or in print), as is demonstrated in novels such as An Instant in the Wind, in which both black and female characters are given voice, and in Looking on Darkness, where a coloured man 'confesses' before execution. In States of Emergency, the implied author/narrator claims, "[t]o tell a story is to drift on language. To be is to be in motion" (48). Here, the fluid attributes of narrative are foregrounded, suggesting the possibilities of a narrative which refutes closure and author-ity. In the framework of this text, a text which is clearly undertaking its own deconstruction, this claim holds the hope of possibility, suggesting that narrative may operate as a tool against the prescriptive - this is Brink's motivating belief. 
To provide a reference point against which the experimental tendencies of this text may be measured, the protagonist is ironically characterised as

[a] sound structuralist $[\ldots .].[w]$ ith, above all, an implicit faith in the text as Ding an sich, an authority to be respected, because it is there, it will always be there, immutable, to return to and be tested. Not necessarily Leavis's 'one correct reading', but at least a predetermined, finite, circumscribed set of permitted readings (16).

Brink's text works to challenge these claims: it actively resists such categorical definition and openly flaunts the manner in which it rhetorically rehearses the mode of its own construction. Melissa overtly challenges post-structuralism, verbalising a challenge to authority and prescription launched by the text itself. She states,

To keep things apart, distinct, separate (man and woman; life and death; beginning and end; the inside and the outside of a text; life and story), to define them in terms of their exclusivity rather than in terms of what they have in common, must end in schizophrenia, in the collapse of the mind which tries to keep the distinctions going. In this lies the failure of apartheid, and the failure, as I see it, of structuralism. What is suppressed, Jung said somewhere, comes back to take its bloody revenge. And surely the most terrible revenge must come from the denial of the fluid oneness of things in favour of the principle of isolation. (195-6)

The text is mimicking in form that which is suggested in terms of content: Melissa's refusal of the binary implications of the structuralist mirrors the text's refusal to be defined in similar, confining, terms, by the framework of apartheid.

In a further resistance to confinement, States of Emergency is an explicitly transtextual and paratextual work in which the philosophies and writings of other artists are constantly drawn on. Melissa, for example, is characterised by her frequent use of the philosophies of Saussure and Wittgenstein in her debates with Philip (130). Further, Philip's various musings on the act and nature of writing include his retelling of an anecdote originally told by Sartre, and reference to Ovid's Metamorphoses to reinforce his point (157) followed by a quotation from Harry Mulisch's The Assault 
(158). In this way, the boundaries of the text are extended beyond its own pages, to include larger literary and philosophical realms. Consequently, the text is viewed as engaging in a form of dialogue with other writers, artists and philosophisers, further evidence of Brink's participation in a 'cultural conversation'. Further, the transtextual interplay speaks to a universal concern with the reflection of one's world, an ongoing attempt to capture 'reality' on the page, with which all writers are concerned - a concern ironically juxtaposed against Brink's deconstruction of the creative process. This foregrounding reinforces the text's concerns with artistic endeavour and responsibility. Thus, each of the frameworks of the text is laid bare, inviting the reader to reflect on its construction.

Brink's transtextual interplay also extends to the remainder of his own oeuvre: this text includes the reinvention of scenes used in earlier works. One of the many iterations of the first meeting between Melissa and Philip provides evidence of this transtextual exchange. Melissa visits Philip in his office and is framed by the darkness of the doorway. The footnote which appends this scene explains the author's reasons for such 'recycling' of literary material:

This scene is, of course, a reinvention of the first meeting between Van Heerden and Nicolette in my early novel, The Ambassador. No doubt other parallels with my previous novels will be explored in the course of these notes. Part of the satisfaction of making them lies precisely in the exploration of alternatives, not only within the emergent text but also in terms of the larger framework of one's work as a whole; and, in fact, of the 'subtle immensity of writings' mentioned by Barthes, which surrounds every newly written text. (19)

Likewise, there is familiarity in many of the details of this text. This literary reinvention is more common as Brink's oeuvre progresses: later novels return to earlier themes and re-enact them, while various works offer a myriad of alternate narrative threads, as are demonstrated in this text. ${ }^{94}$ It appears Brink returns to earlier

\footnotetext{
${ }^{94}$ Arguably, Brink's characters are also reinventions. This would explain, to some extent, the similarities between the women, in particular, of Brink's novels (his female characters generally share
} 
themes, to re-envisage events in an ongoing search for 'answers' and resolution. The overt disclosure of such recycling of narrative incidents and characters in this text is, however, a new device for Brink. Explicit references of this type further expose the construction of the text and specifically draw the reader's attention to this construction. The reader is thus guided in her/his reading and encouraged to consider the implications of narrative construction in terms of its role as a mode of representation.

Narrative irresolution is arguably the central concern of States of Emergency. The crisis of the milieu is reflected in the crisis of the narrating writer. Searching for a means by which to tell a love story, his project is constantly undermined by the political realities of his environment. The text is not, therefore, merely a demonstration of resistance to proscriptive and fixed narrative, but also an indication of the frustrations of the imaginative artist where the theme of love is inextricably tainted by violence. Elleke Boehmer's summary of the text is revelatory: "White writing, in or of South Africa, is clearly a difficult endeavour. Behind the individual white liberal's question of 'what am I doing?' lies the more general, trickier 'what shall be done?"' (166). These two interrelated questions remain the central foci of Brink's oeuvre. As the text concludes, Philip wonders, if ever he was granted a wish, for what would he wish?: "Perhaps only the freedom, the openness, the openendedness, the endlessness - the silence, $[\ldots]$ - of a country for which the future is still possible, a love not yet circumscribed, a story not yet written" (244). This desire for irresolution is essentially a desire for possibility, a rejection of the ostensibly predetermined and constrictive environment of the State of Emergency period in which the outcome appears both horrific and inevitable. The refutation of fixed and predetermined Truth represents, in this respect, a desire for hope: the text may be viewed as a refusal to deny hope, an insistence on possibility. This was the wish during the years 1985-1987, in which the text was written (244).

physical characteristics, similar names and similar past experiences of abuse and degradation). The implications of arguably 'stereotypical' female characters will be further examined in chapter ten. 


\title{
Metafiction as a Disruption of truth
}

\author{
"all that is left is to imagine the real, \\ to improve on what has seemed like truth, \\ to find or invent the shaded meanings of it all"
}

(Brink Contrary 200).

In one sense, States of Emergency is more concerned with the act of creation, the construction of a love story, rather than fulfilling the conditions of the novelistic form itself. In these terms, the text is clearly metafictional. The text constantly moves from romance to the horrors of the South African environment in a juxtaposition which re-defines each realm. The constant commentary in relation to each of the text's milieus is metafictional in that the text is under both construction and deconstruction, simultaneously. As I suggested in the previous chapter, in Brink's work metafiction is a platform from which to critique proscription and prescription and a means by which to counter imperialist narrative models. Selfreflexive narrative strategies such as the use of magic realism, and the undermining of distinctions between binary oppositions such as fact and fiction, overtly foreground the fictionality of both text and language, and therefore undermine author-ity. Further, transtextual and paratextual strategies undermine textual author-ity and point to a range of (often competing) alternative versions. In these ways and others, Brink demonstrates that both narrative and the language in which it is expressed cannot contain any pure truth. As I have argued, this type of critique - a critique which exposes the constructed nature of ostensibly 'truthful' versions of reality - is found throughout the oeuvre, however, in this text, the critique is embedded in the very structure of the novel, in its metafictional framework, rather than merely in its thematic concerns. Metafictional tactics ensure the reader's continual awareness of the constructed nature of the textual, and the arbitrary and implied author/narratorial nature of 'absolutes' such as truth. 
In contrast to realist narratives in which an image is upheld as mimetic, here Brink undercuts both the 'truthful' nature of the represented, and of 'reality'. Brink's challenge to the 'truthfulness' of language and narration is also a refutation of the authority of fixed or authoritarian narratives in which acts of appropriation and dominance are in operation. Brink's continual demonstration of the mediation of absolutes, 'factuality' and 'reality' indicates an interest with the medium through which truth is defined, a concern which will continue to be a primary theme in the texts which follow. Brink's subversion extends to a deconstruction of accepted modes of reality in which he forces the reader's reconsideration of that which is accepted as 'real'. Thus, in texts such as States of Emergency, the distinction between a 'reality' traditionally associated with realism and 'fantasy' is blurred. Brink structures these novels in such a way that the reader's search for the truth is resisted: $\mathrm{s} / \mathrm{he}$ is therefore directed to assess the nature of the construction of each text, rather than focussing purely on its content. In this way, a postmodernist leaning towards the disruption of a linear or singular notion of truth is demonstrated: "[i]n the same sentence, the same story, the same book, in the same view of the world, was cohabit[s] with was not" (Brink "Reflections" 138).

As I have argued, the disruption, or blurring, of binary categories is one of the features used in Brink's work to subvert any notion of the oppositional nature of truth and 'fiction'. As if in response to comments such as those made by Michael Chapman who states, "the southern African situation is too complex [...] to permit choices of either/or" (94), Brink's writing can be seen to answer the request for "not only either/or, but also both/and" (Chapman 97). Brink's work demonstrates that binary pairings are not fixed dichotomies but rather co-dependent and dialectical relationships with an "inherence of each in the other" (Brink Novel 28; original emphasis). He notes that any search for truth "implies also an attack on facile polarities" ("Intellectual" 203) and claims "the old forms of binary thinking have to be treated as suspect and we have to move toward more 'lateral,' more 
'deconstructive,' more 'sliding scale' modes of thinking and of definition" ("Literaure as Cultural" 189). ${ }^{95}$

However, the rhetoric of the preceding quotation, couched as it is in analytical language, is transparent. Brink's reference to "old forms', and the use of mandatory declarations such as "have to" suggest that Brink's position - like that of any dissident - is not merely a challenge to authority but is also itself a claim to authority - a championing of an alternate position. Brink claims the destabilisation of authority, but the manner in which his texts draw attention to this destabilisation is arguably merely a mask behind which his own authoritative position is obscured. What Brink claims is predicated on a failure of truth that points to the concept of a more valid series of truths - truths which he has access to. Brink's explicit exposure of the limitations of narrative implies that there is an alternative of greater value - the alternative(s) he reveals. This realisation - that the dissident represents both a challenge to, and a re-assertion of, authority -will be of note in subsequent chapters related to the revisitation of historical narrative and the literary representation of otherness.

\footnotetext{
95 Similarly, in Postmodernist Fiction, Brain McHale notes the absence "of any third alternative to the polarity of true and false, any mode of being between existence and nonexistence" (106). Further, he records Umberto Eco's suggestion that "worlds in which the law of the excluded middle seems to have been abrogated [...] mount a subversive critique of world-building" (qtd. 106).
} 


\title{
CHAPTER 8
}

\author{
Revisiting History: \\ Re-mythologising South Africa \\ in The First Life of Adamastor, \\ Devil's Valley and A Chain of Voices
}

"Our continent has just invented another" (Montaigne, qtd. in Brink Reinventing a Continent 17). 
"South Africa was invented before it was discovered", claims M. van Wyk Smith (1). He refers to the absence of any pre-literate understanding of the nation, describing the manner in which early literary artists imagined a distant, and as yet undiscovered, land. Later, both during and after colonisation, explorers continued this fascination. In these depictions, as Paul Carter identifies, "the new country is never simply a geographical location and always a historical and poetic destiny" (8). Brink concurs, suggesting that the South African interior is "composed not so much of landscapes and climatological conditions as by the texts [of its various travellers]" ("Rcinventing" 242), ultimately becoming "a wild subconscious in the mind of the world" (Brink Act 28). van Wyk Smith's recognition of the literary preconception of South Africa is fundamental to a discussion of the mythological implications of its political and literary discourses. His statement suggests that one's initial relationship with the nation is framed by a prior knowledge, independent of the physical experience of the land and its peoples, the experience is formulated in terms of a predefined set of criteria. Thus, narratives such as that of the original colonial encounter between white settlers and indigenous black South Africans are framed by predetermined notions of, inter alia, selfhood and otherness, the ideological implications of a belief in white superiority and dominance and a pre-conceived ideal of the naturalness of the conquest of new lands. The colonial encounter is thus embedded in a network of mythological assumptions which determine the articulation of this experience - assumptions which continue to affect subsequent narrativisation of experience. In these terms, Brink's own conception of history is apt: history, he claims, "is not a series of events but a narrated (and manipulated) series of events; and at any moment in the series a mixture of orientations towards representation and invention is evident" ("Interrogating" 21). In these terms, the mythological and historical narratives in which the past is rendered are a further - and ongoing - act of conquest. 
The mythological aspect of historical narrative, its intentionalist role ${ }^{96}$ and the manner in which the mythological is inevitably canonised, are central factors in Brink's examination and subversion of the prejudicial and oppressive context of apartheid South Africa. Brink suggests the significance of myth lies is in "its ceaseless efforts to transcend the mere facts of things in order to arrive at what may be termed their truth" ("Imagining the Real" 215). In this respect, mythmaking may be viewed as a crucial tool in the implementation and maintenance of social customs and behaviours. Mythological and historical narratives operate like any another narrative process: the relationship between narrative and 'truth' hinges on a process of selection. In terms of both colonial and apartheid South Africa, the creation of and reference/deference to a mythological framework is arguably the central means by which ideology is perpetuated, justified and upheld. Several fundamental 'myths' operate within this prejudicial framework. As I have noted in earlier chapters, the mythical relevance of the Bible plays a pivotal role in claims to white superiority and rights of dominance. Diala claims, "the Bible is distorted to a justification of a racist ideology. Like historiography and cartography, theology too becomes a species of myth-making, annexed into the formidable machinery specifically created to empower the Afrikaner Establishment by the presentation of an authorised version of reality" ("Biblical" 36).

Further, a series of pivotal historical moments reinforce the Afrikaner's understanding of her/his place in the nation. The manner in which these narratives of past experience privilege Afrikaners and reinforce the central tenets of Afrikanerdom is crucial. A series of historical 'myths' delineate - indeed determine - the development of Afrikaner identity over the course of the group's inhabitance in South Africa. The first of these is the founding myth of the initial colonial encounter. This narrative establishes Afrikaners as colonisers and missionaries and indigenous inhabitants as inferior in every respect: it is the original discourse of selfhood and otherness in which racial others are found lacking, a process of negative projection.

\footnotetext{
${ }^{96}$ Paul Carter's Living in a New Country: History, Travelling and Language delves into the intentionalities behind history.
} 
A further example of a pivotal moment in the mythology of Afrikanerdom is realised in accounts of the Great Trek into the South African interior. The various (Afrikaner) accounts invariably establish Afrikaners as victims, forced to flee from British imperialists and the (real or imagined) threat of indigenous peoples. Narratives surrounding the 'interference' of outside influences in the affairs of settlers also focus on the issue of slavery; missionary lobbyists urged for the abolition of slavery while settlers depended on the labour they provided. Crucially, claims of victimhood spuriously neutralise Afrikaners' prior and problematic role as colonisers. The contours of the myth of victimhood also establish notions of the hardship and suffering of Afrikaners in a harsh and unforgiving land - the very aridity of the land symbolises lack of sustenance. Claims such as these ostensibly further neutralise any criticisms as to the historical 'privilege' conventionally associated with Afrikanerdom.

The mythological implications of narratives of the Great Trek also include reinforcement of the notion of Afrikaners as die uitverkore volk ([God's] chosen people), a central tenet of the Calvinist church, in which predestination is preached. The journey of the voortrekkers is likened to the exodus of the Old Testament - the search for a Promised Land, a new Canaan. ${ }^{97}$ The travellers themselves are commonly represented in terms of their piety and/or their ability to prove themselves worthy in times of trial. Colonial narratives of the years in the South African interior and the threat of the 'native' further emphasise the perceived hardship of Afrikaners. Thus, they justify the laager mentality ${ }^{98}$ of Afrikanerdom, according to which the unknown (and feared) is forcibly excluded. Further, the hostile and savage behaviour of racial others is emphasised, while the courage, determination and endurance of Afrikaners is stressed. Narratives of the Zulu and Anglo-Boer Wars further reinforce the purported necessity of exclusion and the victimhood of Afrikaners. This sense of exclusivity is implicit in Susan VanZanten Gallagher's summary of these early years.

\footnotetext{
97 The notion of Monomotapa, a fabled African city of riches and pleasure, operates in a similarly symbolic way, promising imagined pleasures ultimately withheld (see On the Contrary in particular).
} 
She notes, "Defining themselves in opposition first to the British, and then to the people of various colours inhabiting the land with them, the Afrikaners developed a nationalistic mythology premised on their uniqueness" (29). I contend that this "nationalistic" overview of (white) South African history is 'mythological' because it is specifically an ideologically determined and ideologically narrated version of historical events. The various myths, both independently and collectively, reinscribe the central tenets by which Afrikanerdom is defined. ${ }^{99}$ These myths purportedly justify the historical privilege and dominance enjoyed by Afrikaners and therefore may be described as "enabling myths"100, in that they support the prejudicial and oppressive environments of both colonial and apartheid South Africa.

Clearly, the historical record of any group may be subjected to a similar critique in which the ideological frameworks which govern or influence their history may be exposed and confronted. As Benedict Anderson professes in Imagined Communities, all communities are "imagined". A series of shared assumptions or mutually accepted narratives establish a sense of connectedness in these groups, homogenising individual experience and belief (15). It appears no group is exempt from accusations of bias and self-justification. English versions of the Anglo-Boer Wars, for example, clearly privilege the English position. Arguably, the extent to which ideology determines the rendition of experience is unrecognised by the group: Afrikaners, for example, may be so indoctrinated into the belief systems of Afrikanerdom that they are unconscious of any alternative relationship with, or reading of, their world. Diala concurs, claiming "[T] myths of the Other's sub-humanity are his own creations taken as truths" ("Biblical" 37). This condition may be viewed as blissful ignorance, or as imprisonment in a

\footnotetext{
${ }^{98}$ Brink notes that, '[i]n South Africa the 'laager,' traditionally the circle of ox-wagons within which Boers secured themselves in battles against black attackers, has now become the spiritual enclosure in which the mind entrenches itself against a hostile world" ("Hour" 31 ).

${ }^{99}$ Isabel Hofmeyer notes "a deeply rooted organic 'Afrikaner identity' which rumbles through South African history and mysteriously unites all Afrikaners into a monolithic volk. However, much recent theorising on nationalism has shown that nations are almost invariably artificial and manufactured categories which can be masked as historically contingent" (Building A Nation 95).

${ }^{100}$ The term is borrowed from A. J. Hassall, who uses it in his discussion of the Mrs Fraser myth (The Making of a Colonial Myth 9).
} 
confining, restrictive framework. ${ }^{101}$ Diala's understanding of Brink's work is relevant in this respect. He suggests that "Brink's insight [...] is the hardening of colonial myths into metaphysical facts and the imperceptible obliteration of the origins of colonial myths even in the coloniser's consciousness" ("Biblical" 37). As I have suggested in earlier chapters, narrativisation is arguably the sole means by which one may articulate and grant meaning to one's world/experience. The mythmaker's narrative acts are inevitably biased by a single perspective as well as by the motivations and justifications of the narrator. In outlining the various foundational myths of Afrikanerdom, therefore, I am not suggesting that Afrikaner mythmaking is a unique or uncommon element of the process of recording history nor is this Brink's claim - but rather that the influence of group mythology is central to all historical record. The mythmaking of Afrikanerdom is merely one example of unitary and exclusive renditions of history. An examination of historical narratives and of their counter-narrativisation in Brink's work is central. Exegesis of this kind is an exploration of the manner in which mythologising and re-mythologising operate as historical and ideological processes; it is an examination of the ways in which political and literary knowledge is determined, policed and inevitably challenged.

Central to Brink's understanding of white mythology in South Africa is his understanding of the manner in which singular and ostensibly fixed versions of historical record - such as those of Afrikaners/the apartheid regime - close off alternative possibilities, effectively disallowing other viewpoints. ${ }^{102}$ Again, Brink's challenge to such practices is centred on counter-narrativisation. His texts reenvisage South African history from a series of alternative viewpoints in order to undermine both the unitary narrative by which that history has conventionally been understood and also the political and social foundations on which it is premised. While this may be viewed as liberation from an oppressive, restricted understanding of historical record, the deconstruction of a fundamental belief system raises

\footnotetext{
101 Again, questions as to the ability of Afrikaners such as Brink to remove themselves from this 'diseased' environment and 'diagnose' it arise.
} 
questions similar to those posed in respect to earlier themes. Historiography's recourse to counter-narratives is as problematic as any other challenge to ostensibly fixed and unitary narratives.

In each of the historiographic texts under discussion in this chapter, the ideological implications of foundational South African myths are addressed. Simultaneously, each text creates a new narrative understanding of the South African era in which it is set. In each case, this process of re-mythologising is offered as a counter to the conventional, oppressive rendition of (white) history. The white view is effectively countered, undermined and contextualised as an ideologically tainted set of understandings by which South Africa's history is traditionally narrated. The manner in which the counter-narrative(s) offered as alternatives to this 'white' view are in themselves critiqued - in terms of their own ideological frameworks - varies from novel to novel and is perhaps the most crucial concern in this chapter. It is for this reason - in order to examine Brink's critique not merely of the mythologies of the state, but also of his own counter-position - that the three novels have been grouped together for discussion. It is beyond the scope of this work to examine the remainder of the novels in terms of their specifically historiographic concerns, as Brink's entire oeuvre deals, to some extent, with this concern. Therefore, I have chosen a selection I consider most representative. In each of the three selected, Brink both exposes and challenges a particular political mythology with a series of countermythologies. In The First Life of Adamastor (1993), ${ }^{103}$ the colonial encounter is reenvisaged from the perspective of the colonised, while the indigenous narrator's own rendering of historical narrative is also ironically problematised. Devil's Valley (1998) usurps the foundational myths of white purity, exclusion and exclusivity in a series of matriarchal narratives which invert the traditional patriarchal record. The text engages directly with the nature of past and present 'truth(s)' and deconstructs

\footnotetext{
102 Notably, black historians at this time were offering 'alternative' versions of history, recording events either absent in 'white' versions, or recorded from a purely white perspective. See, e.g., H. I. E. Dhlomo, Sol T. Plaatje and Thomas Mofolo.

103 This novel was published in Afrikaans as Die eerste lewe van Adamastor (1988). It was also published as Cape of Storms: The First Life of Adamastor in the USA in 1993 and is therefore often referred to as Cape of Storms.
} 
the myth of white purity that frames the community. Finally, A Chain of Voices $(1982)^{104}$ imagines the historical enslavement of men and women imported to South Africa from Batavia and Mozambique and the economic enslavement of the Khoikhoin or "Hottentots". This historical rendition is told not merely from the perspective of the enslaved, however, but rather engages a myriad of both black and white viewpoints. The result is a series of contestatory renditions of a pivotal historical event in which the accounts of both master and slave are putatively under dispute. Ultimately, however, the reader favours the oppressed voices, a factor which problematises the interplay of 'equally truthful' accounts. A brief examination of each of these texts will provide means by which to discuss the mythologising and remythologising of South African history in terms of both social and political implications. The discussion will also allow further consideration of issues related to the authority associated with narrative. ${ }^{105}$

\section{The First Life Of Adamastor}

\section{"One upon a time there was and there wasn't"}

(Brink First 1).

The colonisation of Southern Africa, and the representation of that process, are both central to consideration of subsequent relations between land and settler, and between indigenous and settler inhabitants. Narratives of first contact are a primary topos in colonial literatures, and South Africa's literature is no exception. A literary obsession with the desire and fear of both the hostile land and its original inhabitants recurs in settler literature, and still reverberates in contemporary works. As van Wyk Smith asserts, "Just as the history of South Africa essentially became the history of the struggle for the land and its resources, so its serious literature would turn out to be a record of the mythology developed by its people to justify or resist that process" (3). He claims that the myth of first contact is pivotal in this respect: "The literature

\footnotetext{
${ }^{104}$ The Afrikaans version of the novel was published under the title Hou-den-bek in 1982. The English version is not a translation, but rather an independent text.
} 
of the British settlers, and of much of the colonial period that followed, is largely the record of reinterpreting and modifying the founding myths of the Cape" (6). Issues of appropriation, of both the land and its inhabitants, are the primary focus of such examinations, as they reflect an historical precedent for the relationship between black oppression and white privilege. This issue was of particular importance in the last years of the apartheid era when this novel was written: Brink returns to original encounters in order to imagine a way forward. ${ }^{106}$

The myth of Adamastor has been described as the "root of all subsequent white semiology invented to cope with the African experience" (Stephen Gray qtd. in Cyril Coetzee 6). The myth is not merely fundamental to South Africa but also has literary precedence in traditional European literature. In the introduction to the text, the narrator makes specific reference to Rabelais' Pantagruel, in which the genealogy of giants includes the first known reference to Adamastor (1). However, it is with the text of Camoes' The Lusiads (1572), that he is fascinated. In Canto 5, as Portuguese explorer Vasco da Gama and his fleet approach the Cape of Good Hope - their first journey from Lisbon to Calicut round the southern tip of Africa - a black cloud threatens the group, and assumes the form of a monstrous being. The horrific physicality of Adamastor is the primary focus, a depiction which relates specifically to initial colonial experiences of the landscape. ${ }^{107}$ Such depictions fascinate the implied narrator of Brink's text who claims, "I have been nagged for a long time now by a particular question: from what raw material could Camoes have fashioned his typically sixteenth-century European version of the story? Is it possible that behind it looms an original, an unwritten Urtext?"' (6). Brink's novella is offered as this imagined urtext. His reinvention of the myth concentrates on one element of the Rabelais myth in which the protagonist becomes fascinated with the sea nymph Thetis and, wishing to marry her, is betrayed.

\footnotetext{
${ }^{105}$ These aspects of the discussion will be further addressed in the concluding chapter.

${ }^{106}$ Speaking of his abandonment of the manuscript some years prior to its completion and publication, Brink notes, "[w] ith apartheid gradually receding, I think there was more of an opportunity to go back to some of the gaps and silences imposed by those years... All these things had been accumulating, wanting to be written, and now I can do that"(de Waal 3).
} 


\section{Revisioning of Historical Precedents}

$$
\text { "[...] remember. }
$$

To put the members together again, to reconfigure"

(Brink Rights 92).

Brink's text may be viewed as a reactionary narrative, a direct response to the 'white view' of traditional narratives of first contact. The text addresses issues of identity, cultural contact, conflict and assimilation and reconfigures the Eurocentric perspective assumed in the narratives of both Rabelais and Camoes. In opposition to Camoes' endorsement of Western knowledge and power, Brink's novel undermines the role of the West in Africa; in this way, Luc Renders suggests, Brink's text is not merely pre-text but also post-text (6). However, rather than merely inverting the narrative viewpoint and countering the coloniser's myth with that of the indigenous, Brink's text also incorporates aspects of previous literary renditions, including, specifically, that of Rabelais. The glosses provided at the commencement of each chapter are one of many devices mirroring Rabelais' original narrative model. Likewise, the bawdy humour of the novella and the implicit focus on serious historical themes reflect Rableais' work. Further, the novella represents a blend of ethnic, cultural, religious, and historical influences. Intermingled in the text are references to classical and Biblical martyrs (C. Coetzee 21), allusions to 16th century literary figures such as Rabelais and Erasmus, instances of Christian and Khoisan cosmology (Brink "Reimagining the Past" 54), and parables which incorporate Khoi folk and European creation myths (C. Coetzee 15). The re-narrativisation of material from previous literary sources suggests that the novella be viewed not solely as a counter-text, but as a further episode in an ongoing renegotiation of fundamental myths. Thus, the text engages in an intertextual literary dialogue rather than operating as an isolated, purportedly conclusive and static version of history. The "defiant trans-historical voice of T'kama" of which C. Coetzee speaks (21) gestures

\footnotetext{
${ }^{107}$ Sandra Chait claims that "Although Camoes' Adamastor is not specifically described as black, his epic has been interpreted by white South Africans as inferring color" (27).
} 
towards a continual process of historical narrativisation, representing the manner in which an ostensibly fixed and singular 'history' is instead a process by which historical moments are revisited, renegotiated and renarrated. Rather than discarding or negating the relevance of earlier renditions absolutely, Brink's novella instead draws on these literary antecedents and reconceptualises them in order to reflect Brink's acknowledgement and foregrounding of alternative viewpoints and contestatory renditions. It is in this dialogic relationship that the text countermands, to some extent, criticisms regarding its arguably 'biased' mode of delivery and content.

Brink's proclaimed intention, in respect to this text, is to re-examine the 'curse' looming over Africa, and to explore possibilities for a less onerous future for the nation's various inhabitants. Brink recognises that the original curse of Camoe's Adamastor permeates South African literature in English as a motif of guilt and redemption (Brink "Reimagining the Past" 55). His imperative is to find some (narrative) resolution to this curse:

Adamastor's utterance must remain a curse as long as one thinks of Africa as the other, a dangerous, unexplored, dark continent. But the moment a process of identification begins, when opposites like black and white, or male and female, or whatever start merging, and we discover what they have in common without having to deny what makes them different, then I think the curse can be turned upside down. (Brink "Reimagining the Past" 55)

In order to examine the inception - and, by implication, the continuation - of this curse, Brink interrogates two specifically Eurocentric myths related to narratives of first contact. Firstly, he investigates the myth of Africa as the heart of darkness and secondly, the sexual prowess and potency of the black male subject (Graeber 23). Brink claims that in each of these myths lies "serious concern with the origins of racial animosities in South Africa and everywhere" (Graeber 23).

The depiction of Africa and of its indigenous people as 'the heart of darkness' is central to any examination of race relations in a colonial or neo-colonial context. 
Traditionally, the land and its people are described in terms of their otherness, descriptors which both reflect and inscribe fear and suspicion of a figure who is at once seen as unknown, uninterpretable and unknowing, ignorant, benighted. This figurative darkness represents, therefore, a lack of enlightenment in regard to the other - usually black. In a colonial context, this understanding of darkness relates both to the other and to her/his abode, the land. As I have suggested in previous discussions surrounding self/other relations, the indigenous 'black' subject is traditionally represented in overtly negative terms. In literature, as in history, s/he is traditionally the object of narration, rather than narrator and, without agency, is unable to contest negative representation. In Brink's texts, voice is granted to the historically silenced or muted subject foregrounding the possibility - indeed the existence - of alternative viewpoints. In this way, the fixity of oppressive discourses is challenged. In response to colonial narratives narrated from a European standpoint, Brink's text inverts the narratorial perspective, subverting and problematising traditional depictions of original contact between coloniser and colonised. The arrival of the Europeans' ships is narrated from the perspective of those on land, rather than by the colonisers. Crucially, the ships and their occupants are described in terms which foreground their strange appearance and demeanour - an overtly satirical inversion of the manner in which indigenous subjects are commonly described in exploration journals. The ships are envisaged as gigantic birds, and the smaller boats which row to shore are described as being laid, like eggs, from beneath their wings. Likewise, the beings who eventually come ashore are considered bird-like, their unshaven visages and their clothing imagined as a covering of feathers ( $1 \mathrm{ff}$ ), and the sounds they utter described as "bird-like" (48). In this respect, the text makes ironic reference to the common practice of describing native subjects in animalistic or bestial terms. Simultaneously, the text points to the way in which the initial selection of a metaphorical label (ships as birds) recurs as a descriptive reference point.

In contrast, the customs, dress and behaviour of the indigenous narrator and his tribe are 'normalised'. Inevitably, the narrator's familiarity with his homeland and his tribe imbues his descriptions of them with a sense of normalcy which is 
strikingly absent in his depictions of the colonisers and their 'abode', the ship. Further, the narrator describes his people in terms which emphasise their clearly defined system of governance, tradition, custom, and religious belief (24), undermining historically conventional depictions in which the indigenous subject is described as irreligious or heathen, ignorant and - significantly - incapable of selfgovernance. The veracity of the narrative of the colonisers is further subverted by the narrator who admits he is unsure which explorer first landed on the shores of the Cape (13). In this way, he undermines the authority of official accounts in which such details are the crucial foundations of historical narrative. The inversion of the white view and the suggestion of the uncertainty of historical evidence each operate in a clearly subversive manner. The reader is forced to view the colonial encounter from a perspective alternative to that conventionally assumed in (white) historical record, to re-envisage initial colonial contact between white and black. The 'conquest' of a 'newly-discovered' land is re-envisaged, from the landward side, as the appearance of strange creatures with bizarre habits of dress and custom who are described in often insensitive and ridiculous terms and subjected to a narrative in which they are couched in terms of otherness, a role conventionally associated with blackness. In this case, colonisers and their domiciles represent the "heart of darkness' - the unknown, misunderstood and misrepresented - while the 'colonised' narrator is redeemed as an authoritative figure. Thus, the unitary and fixed nature of official, traditional accounts is undermined with the offering of an alternative narrative of first contact.

Further, there are obvious shortcomings in the indigenes' account of the colonisers. This demonstration of cultural unfamiliarity - which applies to both the coloniser and the indigene - provides commentary on the limits of subjectivity, intersubjectivity and claims to objectivity. It encourages recognition of the manner in which both sides are subject to limitations of perspective and suggests that assumptions of objectivity are equally problematic. 
Thus far, I have suggested that the sense of otherness found in traditional colonial accounts of the black subject is inverted. It must be acknowledged, however, that, ultimately, the text is authored - if not narrated - from a position of power; implicit in Brink's position as an Afrikaner in South Africa is the possibility of the misuse of this privilege. His black characters are authored from a position which does not - indeed, cannot - understand or narrate a culture from the inside. In this respect, Brink's authorial stance may be imagined as a form of mimicry likened to that performed in the text: any form of representation remains at a remove from the experience of otherness and can only ever be a(n inevitably flawed) interpretation.

Sandra Chait's criticism of the novella focuses on a concern with perspective, contending that ultimately the text upholds a 'white view' and the black subject is ridiculed. She refers, specifically, to an incident in which T'kama attempts to woo the white woman, Khois, by mimicking the dress of the bird-like white men (Brink First 50ff). The act of mimicry is of crucial significance in the text, gesturing towards the processes of (mis)interpretation at play in any form of representation and foregrounding issues related to perspective. T'kama's garb of feathers and grease is so bizarre as to evince hysterical laughter from his intended sexual partner. Chait argues that this type of representation merely furthers traditional negative depictions of the native subject. It must be acknowledged, however, that on this particular occasion, T'kama adopts a style of dress he considers best represents the bird-like characteristics of white men. Further, T'kama produces what is considered - from a European perspective - an inaccurate representation. The absurdity, therefore, operates on a number of levels, pointing to the vagaries of perspective. It is unfortunate that the woman's hysterical laughter also situates T'kama as an object of ridicule, but the reader must acknowledge that, in representing Khois' reaction, the narrator and his narrative do not endorse this attitude; here is a clearly maintained distinction between the intentionalities of characters and the manner in which they are represented. This incident provides opportunity to consider the multiple instances and levels of misinterpretation at play in the colonial encounter described: T'kama both misunderstands and is misunderstood; he is both judge and judged. 
Chait focuses on such misunderstandings as further evidence of the uneven power play in operation. "[T'kama's] cultural mistakes", Chait claims, "make him an object of ridicule, while [the white woman's] - tramping on a mantis (Brink First 72) or killing a hare for food (Brink First 91) - confer power, in that the Khoi people believe her to be a carrier of death and fear her presence among them" (Chait 19). While Chait's examples do indicate an unequal distribution - or rather understanding - of power, a demonstration of inequality does not equate to its endorsement. I contend that the power imbalance is represented in such a way that any suggestion that it is fundamental is undermined; it is instead established as a function of circumstance. Chait's claims suggest that, in the usual exclusionary model - of the black by the white - there is no power conferred on the excluded black. However, if there were indeed no (imagined or real) power attached to the black subject, then there would also be an absence of fear. The superstition and fear conventionally appended to the black subject is directly correlated to a fear of the power of 'blackness' and of the qualities traditionally ascribed to blackness. In this text, this fear is arguably transferred to the white subject (here the racial other) and she becomes representative of the power of stereotypical 'whiteness'. The power granted to the white woman is not a reflection of actual white power as exhibited in colonial or apartheid South Africa, but rather a further instance of the inversion of prejudicial superstition and fear. When understood in this way, the imbalance of power further mimics and inverts the traditional depiction of black stereotypes in terms of a conventional 'white' viewpoint. In this way, the text points to the very fears and motivations behind exclusionary practice, and demonstrates these from an inverted point of view.

The second Eurocentric myth revisited in this text concerns the sexual virility and prowess of black male subjects and their assumed desire for white females - a myth also treated in An Instant in the Wind. ${ }^{108}$ Conventionally, the imagined

${ }^{108}$ Chait argues that the sexual signifier of the penis is represented "supposedly free of, because prior
to, the connotations the reader familiar with colonial discourse knows it to carry, namely, the European 
narrative of miscegenative contact includes the sexual pursuit of white women by black men, the impregnation of these women and the birth of miscegenative offspring - sullying an ostensibly racially pure group. As I have suggested in earlier discussion surrounding the theme of miscegenation, the sexual potency and threat of the black man is a theme which permeates the literatures of colonial nations and remains a dominant motif in both South African art and literature. The concern with miscegenative intercourse and, specifically, interracial rape points to the same fearand assumed threat - of transgressive otherness found in all self/other relations (but more specifically the fear of pollution). Historically, the concern with interracial sexual liaisons hinges on an assumption that the black male subject is both sexually motivated and well equipped to impregnate the white women responsible for maintaining and safeguarding the continued 'purity' of whiteness. Further, sexual liaisons of this kind are commonly depicted as acts of 'appropriation', in which the white woman is viewed as usurped property (van Wyk Smith 58). Sander Gilman's examination of sexuality, race and madness includes investigation of the sexual stereotypes attributed to various racial categories. He notes that both male and female black subjects are commonly associated with concupiscence (99) and that this association may be traced to the Middle Ages (79). By the $18^{\text {th }}$ century, he argues, black subjects - whether male or female - became "icon[s] for deviant sexuality in general" and were invariably coupled with white figures of the opposite sex in art and literature (81). He suggests that this historical stereotyping is indicative of an innate fear of the difference in anatomy of the other (107), an understanding central to the novel under discussion.

In Brink's text, the assumptions of black sexual potency and prowess are ironically represented. The narrator is named for his large penis - T'kama translates as "Big-Bird" and in the Khoi language, 'bird' is also slang for 'penis' (14). The initial meeting between the narrator and the white woman - a further narrative of first contact - is revelatory in terms of the comedic representation of sexual mythology. 
T'kama discovers Khois at a pool of water and it is evident (to a contemporary white reader) that she feels threatened by the black figure before her, attempting to distance herself from him. T'kama, however, attempts to allay any fear by removing his only item of clothing, an apron covering his genitals, attempting to demonstrate that he has nothing to hide. Unfortunately, his already large sexual appendage further enlarges as he nears her (from then on, it increases substantially in size every time she is near). Comically pursued by the naked and engorged figure of T'kama, the woman's subsequent actions reflect her fear of rape and reveal the layers of intercultural misunderstanding at play (24ff, esp. 27-8). Further, the respective racial positions represented by the colonial woman and the colonised subject configure this incident in terms of interracial intercourse (in its various forms).

Ultimately, the figure of T'kama becomes secondary to his sexual appendage - in both literal and figurative terms. Crucially, the union between T'kama and (the now enamoured) Khois cannot be physically consummated until he is effectively castrated. During an incident in which he rescues Khois from a crocodile attack, T'kama's penis is amputated by the reptile and he is reduced to a eunuch (108-110). The healer of the tribe fits a prosthetic penis and uses magical methods to bring it to life (112ff) and T'kama and his lover are finally able to consummate their relationship sexually. Interestingly, the black subject's castration enables interracial (sexual) union.

The brief outline of the sexual content given above raises a number of issues in respect to the representation of black sexuality in the text and the implications of these depictions. Notably, the fear of rape evident in the actions of the white woman is later countered by her acceptance of, and desire to engage in, (interracial) sexual intercourse with T'kama. The implication of this acceptance is that sexual fear-like any other - is attached to the otherness of the (here black) male subject, rather than to any actual physical threat. Once this otherness is overcome - in the text, barriers between self and other begin to dissipate when the two learn one another's language - 
the fear dissipates. However, the immensity of T'kama's sexual organ is not merely a comic representation of the myth of black sexual virility and prowess, or the threat this implies, but is also a physical barrier to their sexual union. ${ }^{109}$ The implications of this sexual metaphor, and of T'kama's subsequent castration, are significant. Does the protagonist's enlarged penis signify that miscegenation is unlikely, undesirable, impossible or merely difficult? If miscegenative union is ultimately dependent on the castration of the black subject, does such castration represent the rejection of stereotypes associated with the black subject - such as that of sexual potency and prowess - or does it instead symbolise a loss of power? Sandra Chait is critical of the text in this respect. She suggests that the impossibility of sexual union symbolised by T'kama's increasingly large appendage is reinforced by disruptions to the natural order each of which is related to the drought: boiling rivers, trees destroyed by the heat, and so forth (104) signify an unnatural and undesirable state, disfavoured by the gods. She suggests that it is the pairing of black with white which is ill-favoured: "Such bodies just do not fit, the first item in the mytheme of miscegenation registers; they are purposefully ill-matched by nature, the second notes; and nature, claims the third, is but an expression of the gods' own will" (20). Further, she compares this 'mismatch' to the sexual use of black women by the Portuguese sailors: "No sign of physical mismatch registers textually in the mating of white men and black women", Chait argues, "revealing perhaps that Brink's biases are phallocentric" (20). The phallus is clearly a symbol of generative power in this text. T'kama's enlarged sexual organ is, however, also a practical illustration of the absurdity of the myths surrounding black sexual potency; the phallus is here so engorged as to render its owner impotent. Thus, the putative threat of the racial others' sexuality is negated and the myth surrounding that threat ridiculed.

Apropos of this text, Brink notes that T'kama's castration was necessary "so that man's love for woman could be consummated" ("Reimagining the Real" 52). Interestingly, his statement addresses none of the racial concerns surrounding the

\footnotetext{
${ }^{109}$ In this respect, Abdulrazak Gurnah suggests that Khois "represents Europe as the irresistible nymph who provokes Africa's penetration but cannot bear it" (21).
} 
incident, but instead focuses on the gender pairing. In contrast, critique of the text, and of this incident in particular, centres on problems related to the interracial nature of the pairing. Mario Vargas Llosa suggests that the "dismal" symbolism of the scene refers to the renouncement of selfhood and the replacement of identity with a false one which is the cost of understanding between peoples of various ancestries and cultures. This loss of identity, he claims, is due to the domination and submission in operation in any interracial or intercultural relationship (23) - the imperialist nature of union identified in States of Emergency. Further, Chait describes the metaphorical loss as a "sacrifice" (20), critiquing the implicit suggestion that it is the black man, solely, who must make the sacrifice necessary to unite black and white (20).

However, Chait's conception of the castration as a 'sacrifice' incorrectly implies that T'kama offers his manhood in return for some sense of propitiation. It is my contention that what occurs is the will of T'kama's gods who consider the act either due punishment or reward for his behaviour. Alternatively, his castration may be understood as a readjustment of factors to accommodate new conditions ( $T$ 'kama's eventual rehabilitation provides evidence). The suggestion that the castration is a punishment is reinforced by the disorder of nature and Chait's linking of this disorder to the displeasure of the gods. The castration may be read as the gods' attempt to revoke all sexual privileges and thus forever disable any further attempts by T'kama to engage in interracial intercourse. Alternatively - if one understands T'kama's deities as omniscient - his castration may be understood as a release from sexual frustration and the allowance of unification with the white woman. Notably, the rain which signals the consummation of Khois' and T'kama's relationship also signals the end of the drought and re-orders the natural world (115-7) - surely the rain signals the pleasure of the gods? Crucially, the drought and the bad luck associated with the presence of the white woman both cease when she is fully accepted into their midst and when the self engages fully (sexually) with the other. Again, Brink's abiding concern is that the central "natural order" to be restored is that between male and female. The problems associated with the interracial version of this union are proven 
'unnatural' as compared to the overriding 'naturalness' of the imperative. The 'bad luck' associated with the white woman may simply be ill luck related to the failure of either side to overcome the barriers necessary to achieve this most 'natural' of all goals.

This re-establishment of natural and social orders promises a similar balance in the future, a hope unrealised in the novella. ${ }^{110}$ Whether described as sacrifice, punishment or reward, or simply practical readjustment, T'kama's loss is of concern in the terms to which the sexual metaphor points. Arguably, T'kama's alleged 'sacrifice' is a failure in respect to the current generation - the white woman returns with her compatriots and T'kama is murdered by them - and represents 'union' only in terms of the unborn child which Khois carries. If their union is symbolic of all contact between black and white South Africans, then it is at once a figure for possibility (these two model how apparently insuperable differences might be overcome) and a recognition that, at this point in history, this possibility (for genuine, cultural union) was squandered. It would, indeed, be naïve to represent this pairing as an ideal achieved, given the historical context of black/white relations in South Africa. In a furtherance of Chait's claims, the 'sacrifice' is both solely on the part of the black man, and is also a contemporary act made in the hope of a better future. In terms of the historical implications to which this text points, what is noteworthy is that the 'sacrifice' is made - T'kama loses both his 'manhood' and his life - and yet the white history which follows such colonial encounters continues to discourage/negate miscegenative acts. What then is the benefit of the 'sacrifice' of the black subject? At the level of its narratorial predicates, while not remaining radically open, the text nevertheless sustains a degree of equivocation.

Some exegesis of the criticism related to the use and effect of the specifically sexual metaphor in this text is necessary in order to discuss the text's examination

\footnotetext{
${ }^{110}$ Although the text was first published in 1993, the novella was written in 1985 during what Brink describes as "the very darkest period of apartheid". He notes, "it did not seem possible that we would ever experience the kind of change we are going through now. There was only a vague hope that in
} 
and critique of historical mythologies. First, it is necessary to emphasise that such criticism invariably focuses on the sexual metaphor and its myths to the exclusion of the myth of first colonial contact. Although the sexual metaphor clearly monopolises the text., this should not. detract from the successful inversion of conventional, stereotypical myths related to the colonised subject. The acute and comic depiction of the colonial encounter discussed above suggests that the process of remythologising may be a useful and enlightening means by which to deconstruct stereotypical and prejudiced views of key historical events. In respect to both of the central myths interrogated in Brink's text, there is benefit in an intertextual reading of the novella. This intertextual process is encouraged by the text itself, in the invocation of various literary and historical texts and in the adoption of a traditional literary model. The benefit of this type of reading is the acknowledgement that Brink's text does not purport to contain the 'answers' to central debates, but rather reflects on previous mythologies, deconstructs the means by which they operate and parodies the prejudices on which they are founded, imagining some further possibilities. Textual evidence as to the narrator's unreliability - ultimately he avoids narratorial responsibility - reinforce these claims: by undermining narratorial authority, the text encourages the reader to entertain alternative possibilities rather than one absolute, fixed 'truth'. Resisting closure in this way forces the reader to both acknowledge and participate in the representational process; it does not, however, prevent the text from making a point. Brink's notion of truth is linked to a commitment to undecidability.

Because the novella is not reliant solely on its own rendition of myth, but also benefits from the comparative effect between different versions, the text is merely one component in an ongoing negotiation of myth, its processes and effects. Whether there is sufficient textual evidence to suggest that the author acknowledges the extent to which some of his representations are problematic is doubtful. What is clear, however, is that this text calls on a wider understanding of historical precedent and

the next generation things might change. Perhaps if I began writing this story now, I would naturally begin with a more positive vision of South Africa" (51). 
historical and literary mythology than that contained in its own pages. The effect is to engage in an intercultural and transhistorical reflection on the modes by which the world is narrated and understood. In relation to often problematic representations of the sexual metaphor and its implications and the ultimate irresolution of the issues addressed, therefore, the text is not a failure.

In undermining the implicit accuracy of history and its narration, this novella furthers Brink's epistemological interrogations. The text directly confronts the specific prejudicial and stereotypical myths on which the narration of South African history is founded. Crucially, the text imagines an alternative version of a pivotal historical event and thus emphasises that history is merely an act of narration. The novella explores some of the possibilities for release from the myths of otherness, representing these in terms of conventional colonial and sexual stereotypes. The First Life of Adamastor clearly foregrounds the unreliability of historical narrative, suggesting that both originating myths and subsequent counter-mythologies are shaped and maintained by specific ideological and cultural contexts. Further, Brink's work suggests a causal link between creation (and recreation) of the myth and the contemporary, communal sense of identity. Texts such as this one demonstrate not solely that history is merely an act of narration but also that identity is subject to challenge (and redefinition) by altering/redefining the mythos. The myth-function of history is foregrounded and a central mythos is revised in order to introduce a renovated sense of identity. In these terms, the (specifically white) historical rendition of South Africa's past and the identification of its peoples is placed under review, a process of deconstruction which continues, in varied ways, in the next two texts under discussion. 


\title{
Devil's Valley
}

\author{
“To write up our story $[\ldots .$.$] '$ \\ 'History'
}

'One word is as good as another"'

(Brink Devil 230).

Brink's fascination with mythopoeia continues in Devil's Valley. ${ }^{111}$ As Brink notes, the text reflects further on the myth of Adamastor ("Reimagining the Real" 52), referring back to an initial colonial encounter and the manner in which interracial engagement is refuted by a separatist Afrikaner community. Employing a journalist and former historian as the narrator and protagonist of the novel, this text investigates 'factual truth' and, by implication, history, questioning the validity of historical record and examining its implications. The protagonist, Flip Lochner, travels to Devil's Valley determined to uncover the truth behind the various rumours and legends which surround the settlement. Flip's literal descent into the interior serves also as a metaphorical exploration of the mythologies surrounding Afrikaner identity - specifically, the myth of racial purity. The novel traces his frustrated attempts to separate fact from fiction and his inevitable realisation that 'history' is merely a series of narratives, and that 'fact' is a term used to favour and secure certain narratives over others. In the South African context, the implications of this realisation are central to an understanding of the manner in which historical record is established, maintained and, ultimately, contested.

Investigating the valley and its inhabitants by means of their oral history, Flip is confronted with diversity and discrepancy. The narrator complains, "[a]ll I have, I the historian, I the crime reporter, in search of facts, facts, facts, is an impossible tangle of contradictory stories" (352). A palimpsest of narratives is established in which competing versions occupy the same space and, ostensibly, no one claims

\footnotetext{
III For further discussion of this text see Dixon, "Shouting against Silence: André Brink's Voices of Truth.".
} 
precedence over any other. Flip's enforced reliance on conversations, rumours, myths and personal diaries to reveal the community's past allows a multiplicity refuted in more conventional linear and singular renditions of historical record. An absence of 'official' documentation (44) means that these multiple narratives do not refute any authoritative history, but rather undermine the possibility of the authenticity of one. Thus, the novel tends towards a postmodernist understanding of historical narrative in its challenge to a singular 'reality' or 'truth' and its resistance to closure of this kind.

As in Brink's earlier 'metafictional' texts, the textual aspects which encourage a deconstructive reading in Devil's Valley enforce reading practices in which the acknowledgement of narrative construction and its effects is central. The reader's attention is continually focussed on the construction of 'truth' or 'fact', and 'reality' is thus revealed as merely one (normally privileged) of many possibilities. When Flip complains that "[e]very word spoken here is a bloody new invention" (45), he foregrounds the manner in which all narratives, including putatively authoritative master narratives, are both creative and interpretative processes. In emphasising this, the text challenges the authoritative stance assumed by singular forms of narration such as official historical records. As in the multiple slave narratives of $A$ Chain of Voices discussed below, judgement is placed with the reader and simultaneously withheld. S/he is given no legitimate position from which to evaluate the various renditions in any hierarchical manner, as each is awarded some validity, both in its own right, and as a part of the whole. Thus, singular, fixed truth is seemingly undermined and a palimpsest of competing accounts offered in exchange. Debate surrounding the relativisation of truth - explored in the previous chapter - remains a central concern.

In terms of the fictional heterocosm of the text, however, and despite the townspeople's apparent resistance to closure, fixity and conclusion, there are a select number of fundamental myths which are fixed. These represent the ideological foundations and direction of the community. The most crucial of these founding 
myths establishes that the valley was uninhabited when discovered by the original white settlers. The emphasis on the land as terra nullius, and the community's subsequent exclusivity, putatively establishes both the original and the continued racial purity of the valley's inhabitants and has been used to confer legitimacy. Further, the oral narratives of the settlement are framed in terms of a patriarchal representation of history in which the founding fathers are central. As I will establish, the presence and authority of women in the community is negated or ignored by the male members of the valley. The persistence of this particular founding myth and of the patriarchal narration of the past is revelatory in that the palimpsestic model of history emphasised by the town is undermined. The town's lack of official, static records previously suggested a freedom of possibly in terms of rendering the past. However, the revelation of the founding myth of exclusivity and racial purity, and an acknowledgement of the patriarchal basis of historical narrative, reveal the prejudice that directs accepted accounts in the community. Throughout the text, these historical frameworks are continually undermined by an increasing number of contestatory accounts and an emerging alternative - matriarchal - historical model. In this way, the foundational myths on which the community has been defined are brought into question as is the manner in which historical record is established and rendered.

\section{History Reinterpreted}

"We have written them [indigenous peoples] out of our history.

$$
[\ldots] \text { An entire history }[\ldots] \text { of errors" }
$$

(Brink Act 490).

The founding myth of racial purity and the continued (physical/ethnic) exclusivity of the Afrikaner community are central to both an historical understanding of Afrikaner insularity and also to the analogous segregational conditions of South Africa. In its interrogation of the act of segregation and the grounds on which this is based, Devil's Valley addresses the macrocosmic situation of South Africa, both past 
and present. The valley is a representational specimen of extremist Afrikaner psychology, scrutinised and dissected to reveal its underlying structure. The myths on which the community is founded thus signify the established myths of Afrikanerdom in South Africa. As I intimated in the introduction to this chapter, narratives of the Great Trek establish the Afrikaner community as a harassed and victimised group, forced to traverse a harsh and hostile land in search of a place to settle beyond the reach of British authorities and the ostensible threat of indigenous tribes. The narratives suggest a desire for a place with which to identify, as well as a longing for both political and cultural independence. The sense of victimhood which characterises the original voortrekkers is ostensibly justification for attempts at exclusion; Afrikanerdom is premised on the laager mentality, a notion of insularity or exclusion which offers protection. This historical context forms the basis for the fictional events of Devil's Valley. The text begins with the premise that "Everybody's hand has always been against us" (79) and details the 'ideal' exclusivity of the Afrikaner people.

Racial purity is the most fundamental of the aims of Afrikanerdom - the putative 'superiority' of the Afrikaner, and the maintenance of authority depends on the careful policing of racial and cultural boundaries - and for this reason miscegenation is forbidden. ${ }^{I 12}$ This veto, however, extends not merely to those of "the wrong colour" (205) but to all 'outsiders'. The community's healer, Tant Poppie, is adamant that "What's in here is meant to stay here, and what's outside must stay out. It's clear as daylight that God didn't want us to mix with others. We got to keep our blood pure" (94). Clearly, the valley's inhabitants consider themselves die uitverkore volk. The reliance on limited theological interpretations, which putatively justify the ethnic exclusivity on which the community was established, specifically reflect the same justificatory ideological constructs in use in the apartheid context. In each, a warped theological interpretation putatively justifies

\footnotetext{
${ }^{112}$ Although this is technically true, Emma explains that only those who choose to publicly flout the law by choosing to give birth to their interracial babies are punished (146). The taboo is further undermined by the re-appearance of "throwbacks" (231-2), reminders of past miscegenation who are stoned to death.
} 
segregational practices which are otherwise morally and ethically unjustifiable. Ironically, (given Flip's later revelation as to the community's interracial genealogy), Tant Poppie adds, "[i]t was God's will that only Boers came in here [....] Kaffirs and Englishmen are enemies (94-5). ${ }^{113}$ The necessity of retaining a racially pure lineage is upheld as a justification for the punishment of those who transgress these boundaries. Emma tells Flip, "[n]o outsider may lay a hand on [the] womenfolk" $(144)^{114}$ and claims her mother was murdered by the townspeople because she was suspected of impregnation by an outsider $(150,167)$. The ideological foundations and political implications of obsessions with racial and 'insider' purity of this kind are addressed by Brink in an essay entitled "The Writer in a State of Siege". Speaking of power, he notes that it "is narcissist by nature, striving constantly to perpetuate itself through cloning, approaching more and more a state of utter homogeneity by casting out whatever seems foreign or deviant" (173). However, warnings as to the dangers of interpretation in the text challenge both the justifications of the inhabitants and the reader's complicity, undermining the historical justifications for exclusivity and prejudice in terms of which Afrikanerdom is conventionally defined.

The accepted version of the community's history excludes darker pigmentation. However, the presence of rock paintings in the area (353) and the endurance of indigenous custom and myth $(104-5,177,298)$ provide evidence of non-settler South African inhabitants in the valley and the settlers' contact with them. ${ }^{115}$ Ironically, the present townspeople claim these myths as their own (105), despite obvious blends of local tribal myth and Biblical characterisation (104-5, 171$2,244-5)$, illustrating the paradoxical nature of the town's history. Ultimately, one of the town's older inhabitants, Seer Lukas, makes a confession to Flip regarding the community's ancestry: “[w]hen we trekked in here [...] this whole valley was full of enemies $[\ldots .$.$] there were Bushmen and Hottentots all over the place" (285). He also$

\footnotetext{
${ }^{113}$ Thus, their prejudicial conduct is not merely versus the 'black', but is instead ethnically based. ${ }^{114}$ Notably, this law applies only to the women, the vessels of future progeny.
} 
admits that his second wife was a "Hottentot" and that the biracial "throwbacks" the community exterminates are a result of this union (285). He claims, "[w]e had to get rid of them to clear a spot for ourselves" (285), "[w]e fucked the whole Devil's Valley white" (286). The discrepancy between this version of events, and others in which the indigenous South Western Africans are wholly absent, illustrates the extent to which extremist ideals of racial purity determine the way in which representation is rendered and accepted in this community. In this text, mythology is exposed as a method by which cracks in an ideological framework are consciously obscured; mythological narrativisation favours and upholds one version of 'truth' by concealing or excluding unwelcome and/or contradictory accounts. This type of contradiction is inherent in all mythmaking. Further, the text demonstrates that the rules by which a myth may be understood as truthful or untruthful are rules of narrative reading, processes of assessing consistency, evidence, and putative teleology.

Historical reminders such as "throwbacks" to an interracial ancestry and the walking dead ensure that the past remains a living presence in the community. Magic realist devices are employed to blur conventional distinctions between the real and the surreal. Yet the various reminders of a past age fail to effectively speak the silences or revisit the absences in the town's histories. In addition to the erasure of indigenous narratives, women's stories are also disallowed - their voices are most often silenced: "They [men] took our whole history" (206). As Flip becomes trusted by the townspeople, he realises that a wealth of alternative narratives exist which contest the (itself contradictory) patriarchal rendition of history. Annie-of-Alwyn recounts one of many feminist accounts of the past when she tells the story of her ancestor, Katarina. When she prompts Flip to promise that Katarina's story will be recorded verbatim, she explains, "[t]hen somebody will at least know about her, you see. And perhaps about me too. It's terrible never to have been known about" (264; original italics). The retelling of history from a matriarchal viewpoint is a redemptive act, granting importance to women otherwise negated in historical terms.

115 Somewhat problematically, the text destabilises the 'superiority' of the townspeople by revealing
their miscegenative past, rather than challenging the fundamental issue of white racial superiority per 
As Flip is confronted with an increasing number of contestatory accounts of the past, he realises that history is inevitably interpretative; that is, in arriving at an historical account, one must select and interpret data. Throughout the text a painting motif is deployed in order to reflect on issues of interpretation and representation, concerns of particular relevance in terms of the text's interrogation of history and myth. Notably, the canvasses of the town's artist, Gert Brush, show evidence of previous portraits, beneath the current image. Flip's description of a portrait of Lukas Death details the palimpsestic effect of the canvas:

like most of Gert Brush's work it had been overpainted many times: on the top layer was Lukas Death as one saw him today, thin and righteous, with his hang-dog face. But clearly visible underneath was another portrait of the same face, only much younger. More shadowy in the background, in deeper half-obscured layers, loomed the ghost of yet another, a quite frightening face with two red glowing eyes. And behind this one still more shadows. (136-7)

There is a practical explanation given for the visibility of previous images. Their existence is explained by his habit of painting over already painted canvases) of shadowy images of the past - Gert frugally dilutes his paints with linseed oil "as a result of which all the earlier faces remained vaguely and disconcertingly visible, staring up at one as if through a bloody glass darkly. (52-3) - and yet the metaphorical connotations are also evident. The overlaying of images points to the manner in which historical process operates: history claims to narrate various past moments as equally true in themselves, but teleology operates as a function of history, suggesting that all previous moments are a necessary part of arriving at the present. The contours of 'the present', however, are ideologically skewed to the vision of the historian and as such, past moments are subordinated to that narration. Thus, the palimpsestic images reflect the historical groundwork which shows through in any contemporary representation. To return to the painting trope, the shortcomings of the current version (thinned paint) allow the images of the past to colour the present image in ways which unsettle and deconstruct its seeming definitiveness, its 
comprehensibility. Further, the overall process points to the manner in which the current version will itself, inevitably, be subordinated by new images. Essentially, the trope is further evidence of the text's exposure and critique of historical processes. Like history, the paintings essentially gesture backwards to previous versions in order to understand the present. Thus, the trope suggests that history is inevitably mythological: the putatively seamless logic behind history is revealed as teleology. History does not have meaning in itself, but rather explains the current moment.

Gert's paintings explain the present moment, but also point to the possibility of progressing beyond the prejudicial view they represent. When Flip views Gert's work, he notes:

[w] hat struck me, like on the other paintings by Gert Brush I'd glimpsed before, was the weird use of colour: everything was done in whites and pinks, like fucking marshmallows, so that all the portraits looked seriously sick to the point of unworldliness. (137)

Further, Gert complains that paint isn't made in "skin-colour" (137). Flip suggests, "I'm sure with only white and red you're never going to get it right. Shouldn't you mix in something darker? Brown, perhaps?" Gert's response is emphatic, "[b]rown? [.... But I'm painting white people" (137). Clearly, Gert's understanding of a suitable palette of colours to represent 'white' skin is shaped by prejudicial ideological beliefs which disallow any suggestion of 'colour' in 'whiteness'. Like the valley's history, Gert's paintings refute darker pigmentation and 'fail' to accurately represent the past. This failure is linked to certain ideological limitations. What is most interesting, however, is the suggestion that representation may be improved; the possibility of introducing new elements into the representational process - the inclusion of 'brown' paint (or narratives) - is proposed. 


\section{The Truth of Devil's Valley}

"The truth, almost the whole truth, and nothing but"

(Brink Devil 28).

Devil's Valley may be considered an historiographic novel in that it engages with epistemological questions in regard to the conception and rendition of historical 'truth'. The novel draws attention to the kinds of racist and patriarchal predicates that the valley's history is based on and, by extension, may be viewed as the type of narration on which apartheid is based and maintained. In these ways, the text undermines the credibility of (specifically colonial/European) history. In deconstructing the hegemonic discourse propounded by the patriarchal and white master narrative of the valley (and of apartheid), Brink demonstrates that unitary, linear or fixed narratives are insufficient representations of history, as they deny the experiences and voices of a multitude of others. In undermining the veracity of the 'factual', this text lays claim to the possibility of alternative 'truths'. Acts of representation, symbolised most notably in the act of painting, emphasise thematic concerns with the representation and recording of 'truth'. The text's foregrounding of acts of judgement and interpretation ensure the reader remains aware of the constructed and often oppressive nature of historical 'truth'. The reader is thus prompted to remain alert to the imposition of dominant discourses and the prejudicial bases upon which these are formed. In the larger context, the singular and fixed notion of 'truth' on which apartheid South Africa was constructed is de-constructed and revealed as shaped by myths of both white and male superiority. 


\section{A Chain of Voices}

"...perhaps someone will hear us calling out, all these voices in the great silence, all of us together, each one forever alone. We go on talking and talking, an endless chain of voices, all together yet all apart, all different yet all the same; and the separate links might lie but the chain is the truth. And the name of the chain is Houd-den-Bek" (Brink Chain 441).

The critique of history (as an archaeological record of fact) is also the focus of A Chain of Voices. In this novel, Brink uses a South African historical event to form the basis for his exploration of historical 'truth'. History records that in 1825, in the Cold Bokkeveld, twelve slaves and a free man revolted against their white South African masters - Dutch settlers - killing three men and wounding a woman. The documentation related to the criminal trial of the accused forms the historical basis for Brink's narrative which re-mythologises the original record. The chapters "Act of Accusation" and "Verdict" frame the novel and an imagined pre-history of the events leading up to the revolt is described between. Dealing with the final years of slavery of black Africans, the text engages with the enabling myth of white superiority and the right to white dominance putatively justified by Biblical injunction. The series of narratives reveals a thematic concern with the nature of oppression and of mutual bondage - the oppression of self and other, oppressor and oppressed, found in earlier texts is here defined in terms of master and slave.

Inevitably, the text also focuses on the nature of, and desire for, freedom and it is the unfulfilled promise of freedom which ultimately leads to the rebellion of the slaves against their masters. This is paralleled by the rebellious nature of the text itself, which also speaks out against prejudice and oppression. The novel delineates a period in South Africa's history in which the emancipation movement was placing increasing pressure on the government to free the nation's unpaid labour force. The effect of this promised freedom, and the frustration of both slave and master is the 
central focus of the plot, reflecting a similar frustration in contemporary apartheid South Africa. During this period, Brink declared,

Blacks in South Africa live in exactly the same situation today. There was the sudden hope triggered by the liberation of Angola and Mozambique and Zimbabwe. Then the fall from grace of Vorster and the totally unexpected promises made by P. M. Botha, which of course haven't come to anything. We're at this stage of terrible frustration at the moment. (qtd. in Wheatcroft 15)

This mood is important to motivate the plot and yet the novel's effect extends beyond these particular concerns; it is in its interrogation of historical narrative that the text is most effective.

The events surrounding the slave uprising are told from a variety of perspectives, creating a polyphony of thirty narratorial voices, each of which offers a different narrative version of events. The layering of narratives represented in this novel, Brink claims, was inspired by the original legal documentation related to the Bokkeveld uprising. He notes that, while reading these documents, he recognised traces of the slaves' voices within them: "occasionally, in unguarded moments as it were, could one hear, in an unexpected or ungrammatical turn of phrase, the 'original' voice of the speaker sounding through the palimpsest of transcriptions" ("Rcinventing" 239). Brink's use of the term 'palimpsest' to describe the various narratives returns to the notion of a layering of versions, each of which is inextricably tied to previous renditions. ${ }^{116}$ The reader is, therefore, again urged to acknowledge the teleology behind the refinement of historical accounts into a single, linear narrative. Brink notes that the original documents on which the novel is premised "brought into doubt most of the official versions of slave history in South Africa. (The very way in which such a significant episode had become 'lost' in official history, speaks volumes)" ("Reflections" 135). Further, he recounts, "[w]hat struck

\footnotetext{
${ }^{116}$ Ultimately, however, each account is judged against the legal record which encloses the text and the reader's sympathies lie with the condemned and executed slaves. The reader is ultimately discouraged from empathising with the perspective represented by the official accounts - the impersonality of their narration disallows any such identification.
} 
me $[\ldots]$ was the way in which the depositions of all the witnesses and accused in the trial had been transcribed by court officials (and, in fact, the scribe(s) had left more than one version of his/their transcriptions behind)" (239; original italics). This putatively 'factual' historical documentation, therefore, is revealed as tainted with inaccuracies and omissions, as well as repetitions and variations, which Brink expands into his own narrative. He emphasises and embellishes discrepancies between the respective narrators' versions and also between these versions and the act of accusation, predicting and resisting the reader's search for a singular 'truth'. Brink foregrounds the act of interpretation and the role of perspective in attempts to search for (here specifically historical) 'truth'.

Although predominantly concerned with giving voice to the slaves on whom silence has traditionally been enforced, the novel adopts the variety of perspectives imaged in the title - including those of the white 'masters' - allowing each member of the "chain' to speak and revealing how each is silenced, rendered inarticulate, or misinterpreted, in diverse ways. The confused and contradictory composite 'truth' which results, the text suggests, is a more complete reflection of a specific historical moment than the 'official' documentation which frames the text. Each of the voices and versions is linked, either by ancestry or circumstance. In creating a chain of voices which speaks out against silencing, Brink figures the chain as an image of the bondage of the oppressed and reclaims it as a means of allowing the slaves' stories to be told. The chain of voices represents a form of collective power and freedom from the oppressive position of silence and misinformation rendered in a purely colonial version of history. Each voice is both an independent link, and a part of the complete chain. No one link/voice has the ability to narrate every event, and each is limited to a singular perspective.

Throughout the novel, a series of events are retold from different perspectives, each of which offers a further dimension to the reader's understanding of events. Several narrators, for example, describe Hester's shorn hair, each of them infusing the act with her/his own interpretation. Alida Van der Merwe, Nicolaas' mother, and 
informal foster mother to Hester, takes great pleasure in brushing the girl's hair and is upset when she discovers it has been cut: “[o]nce again she'd asserted her independence from me; once again I was reminded that the solace I'd found in our relationship was my illusion only, no part of her reality" (79). Nicolaas also adores Hester's hair and recounts, "[u]ntil she discovered how much I loved to stroke or touch her long dark hair she would absently resign herself to my caressing; but once she'd discovered my addiction she cut it all off" (91). It is not until each of these self-centred interpretations of Hester's action has been narrated that Hester herself reveals the motivations behind her haircut. She notes that her step-brother Barend's bullying includes pulling her hair, and that "the only way to thwart him was to hack it off' (103). A further revelation, absent in both Alida's and Nicolaas' accounts, is the extent to which this upset Hester herself: she recalls that she lay in bed that night crying and "fingering the stubble in the dark" (103). Clearly, neither Alida nor Nicolaas views Hester except in relation to themselves, and thus, partial-sightedness is foregrounded.

In the ways described above, each character expresses her/his own beliefs or 'truth', each of which is subsumed by yet another individual perspective. Each singular narrative therefore resonates with traces of previous versions, is viewed in relation to these, and the context within which each operates is revealed. The result is a conglomeration or layering of differing perspectives and beliefs which ostensibly offers a fuller and more 'truthful' account (if not the 'truthful' account) than that of any singular narrative - an effect similar to that created in later Brink texts in which metafictional devices blur conventional distinctions between reality and unreality.

\section{Silence}

"a brief shout against silence"

(Brink Chain 505).

In its articulation of subordinated narratives, the text counters the threat of 
silencing posed by authoritarian and oppressive regimes. Traditional acts of silencing are symbolised by the farm of Houd-den-Bek. ${ }^{117}$ The property represents a place of refuge to which Grandpa Van der Merwe, the ancestral patriarch of the Van der Merwe family, trekked after quarrelling with the authorities. Translated as "Shut Your Trap" (501), the name appears to disallow any voice to those who would refute its own authoritarian stance. As Grandpa Van der Merwe stated when officials came to summon him from his self-appointed kingship, "[i]n this place your word counts for nothing [.... No one but I have the right to speak here" (33). Notably, the farm and its symbolic associations are constructed in opposition to the notion of a chain of voices and thus represent the censorial authoritarianism in operation both in South Africa as it is represented in the novel, and the apartheid regime during which the novel was written (1982).

Although given voice in the pages of Brink's novel, the slaves are granted little or no agential voice in terms of the action of the fictional heterocosm. Galant, who instigates the rebellion, represents those frustrated by disenfranchisement and enforced muteness: "[o]nly through killing", he claims, "can I, perhaps, be heard. I have no other voice" (508). The court's verdict, which concludes the novel, completes the cycle of Galant's enforced silencing: the transcription reads, "we have the evidence of the prisoner's co-accused and of those witnesses who have appeared before us, to stop the mouth of the slave Galant about these charges" (516). Throughout the text, Galant represents the victims subordinate to the official account, the narratives of those disbelieved, ignored or denied opportunity to speak. To counter this enforced muteness, Galant's narrative is imagined in Brink's text and he and his contemporaries are given voice, speaking in opposition to - and echoing within - the account of their lives and actions recorded in the legal documentation.

\footnotetext{
${ }^{117}$ The farm's name is used as the title for the Afrikaans version of this text.
} 


\title{
Perspective and (Mis)Interpretation
}

\author{
"Who are they? [....] Who are we?" \\ (Brink Chain 66).
}

The series of misunderstandings and misinterpretations structuring the text emphasise the manner in which narrative is perspectival and inherently ideologically biased. The novel first establishes a context of ideological antagonism and then demonstrates the incompatibility of their respective accounts. There is a striking contrast, for example, between the beliefs of the Afrikaners and those of their slaves. Afrikaner belief in (a specifically Calvinistic interpretation of) the Bible is juxtaposed with the slaves' adherence to the will of the "blue God", Tsui Goab (84) and the originating myths of each group are strikingly diverse. Each of these faith systems crucially shapes the manner in which the characters live their lives and interact with one another. More critically, these belief systems are the basis for any notion of objectivity, so by demonstrating several different systems and not necessarily valorising any one over the others, the text brings the very ideal of objectivity into question. It is suggested that a singular rendition of historical reality will ultimately fail to reflect the 'reality' experienced by each of these diverse groups. As in Devil's Valley, any pretensions as to historical 'fact' are promptly undermined.

The central motif by which the accuracy of historical record is undermined is that of the Cape newspaper which ostensibly reports the contemporary events of the nation - historical truth in process. The symbolic value of the newspaper - as reporter of 'truth' - is granted further significance by Galant's obsession with language, meaning, truth and the newspaper itself. Since the moment when Nicolaas first begins to learn to read, Galant is fascinated with the power of words, and their relationship with meaning. He recalls:

one day Nicolaas flattens a patch of the clay, and smooths it with his palm, and with a twig draws a series of strange marks on it, lines and curls and 
squiggles like the tracks of some small animal. 'What's this?' he challenges me. 'How must I know?' I reply. 'Looks like the spoor of a chameleon.' 'It's my name,' says Nicolaas. 'See? - It spells Nicolaas.' It still looks rather suspect to me. 'How come,' I say, 'that you can be standing over there and your name is lying in the clay here?' (51)

This is one of many - here Saussurean - critiques of the reflection of truth in language and narrative. Galant soon becomes enthralled with the newspapers, recognising the significance they have for his masters. He attempts (and fails) to decode the link between the printed word and its meaning. Without hermeneutic context - in this case, the ability to read - the words convey no meaning. In his inability to interpret the text on the page, Galant recognises a familiar refrain in which he is denied the right to access meaning. He complains, "in the silence of that maddening newspaper, spread open on the flat hard rock, I hear those taunting words again: in silence the rows of black ants run across the paper, telling wild stories of the place that haunts my dreams. But all they say to me is: It's not for you to ask" (54; original italics). The frustration of such denial overcomes Galant and he becomes consumed by the meaning apparently entrapped in the printed words:

[t]he newspaper is burning in my hand. By the Blue God, I think by [sic] myself, is there no one in the whole bloody world who can tell me what this damned thing says? I spread it open on an antheap and peer at all those weird small black ants running motionlessly across its pages. They are talking about me, that I know for sure, yet I can't make out a word they're saying. I press my ear so hard against the paper that it hurts, but I still hear nothing. Then something seems to burst inside me and I start tearing it to pieces; I thrust all the crumpled shreds into my mouth. If they won't talk to me I'll eat them up. Perhaps they'll start talking inside me. (295-6)

The very framework of the text emphasises the impossibility of direct access to meaning - a process of interpretation is necessary. In the novel, court proceedings are used to demonstrate the prejudicial nature of this process of interpretation or judgement and to examine its relationship to 'truth'. Because the text refuses to 
prioritise any one narrative over another, ${ }^{118}$ the reader is forced into the role of judgement, while such acts of interpretation are simultaneously challenged in the text. The impossibility of any one version's provision of 'truth', and also the impossibility of any consensus or composite 'truth', is foregrounded by discrepancies between each of the various characters' statements and the act of accusation and verdict which frames them. The act of accusation, for example, begins with an itemised account of the names, ages and titles of the accused (9) in an effort to record a singular, linear and factual rendition. However, such details are later challenged in the body of the text, and plurality and uncertainty is foregrounded. In this context, the precise legal language and apparently definitive statements recorded by the court are viewed as prejudicial judgements regarding the events that occurred during the uprising. The court's prioritisation of Joseph Campher's testimony over that of other witnesses, for example, is ironically justified by the court because he is considered "a free man and a Christian and consequently entirely trustworthy" (516). In terms of the characters' various statements, the language use in these passages is also ironic. Words such as "truth" (513), "justice" (513), and "proof" (513), for example, bear scrutiny when considered in relation to the remainder of the text. However, rather than just problematising truth, the withholding of resolution at the level of the text (notwithstanding that the official versions proclaim a kind of resolution of their own) foregrounds the readerly desire for resolution. Simultaneously, it is understood that to achieve this resolution the reader will be forced to construct a truth from insufficient materials, to decide in the face of the undecidability of the evidence. Thus, the reader is shown how the official version undertakes this process of selfauthorisation while s/he also understands that the drive for this kind of completion comes from somewhere more or less dark to the interpreter's eye.

\footnotetext{
${ }^{118}$ Notably, Brink's prioritisation of female narratives in later texts such as Imaginings of Sand and Devil's Valley does not occur in $A$ Chain of Voices. Arguably, the sole narrative distinguished as closer to (a) truth than others is that of the insane (female) slave, Lydia. It is her madness, however, which allows her access to this truth, rather than her gender. Thus, this earlier text avoids criticisms related to the inversion of genderism which may apply to others.
} 


\title{
The Truth
}

\author{
"It is, it must be, the truth, \\ the whole truth, and nothing but the truth"
}

(Brink Chain 449).

Arguably, historical 'truth' appears intangible. Frans Du Toit, Field-cornet of the settlement and investigator of the events surrounding the rebellion, articulates the problematic nature of ascertaining and reporting truth:

I thought I knew what had happened. I did what was expected of me, neither deterred nor encouraged by our several histories. Beyond the passions and terrors of our personal involvement lay, small and sordid, what seemed like irreducible fact. Now, having taken down all their statements, each the summary of an existence, I am perplexed by the obscurity of truth. Where does it reside? In these affirmations and contradictions, this incipient patter, or somewhere in the wild and senseless groping of that initial action preceding the word? Does it evolve from the litany of repetition, or is only the unutterable true? Can the virgin be celebrated except in the act of violation, or innocence established except in its corruption? (442)

Du Toit's gropings towards a definition and foundation of historical 'truth' encapsulate the novel's concern with the same, outlining the various ways in which the question is approached in the text. As in Devil's Valley, A Chain of Voices demonstrates historical process in operation. Beginning with a putatively 'factual' account of the uprising, the text then imagines some of the many subordinated accounts behind the one ultimately recorded. The novel illustrates how this ideologically-orientated process operates and invites its critique. Simultaneously, however, the reader is forced to participate in the same teleological process. In each of these texts, Brink establishes that history is mythological in intent and content; it is both determined by, and reinforces, an ideological standpoint. The very basis on which apartheid South Africa was founded - the belief and adherence to one dominant group's notion of 'truth' - is thus deconstructed and revealed as prejudicial. 


\title{
Conclusion
}

\author{
"the representations of history repeat, \\ in almost every detail, the processes of fiction"
}

(Nuttall and Coetzee 32).

"History", Brink claims, "provides one of the most fertile silences to be revisited by South African writers: not because no voices have traversed it before, but because the dominant discourse of white historiography (as well as temptations to replace it by a new dominant discourse of black historiography) has inevitably silenced, for so long, so many other possibilities." ("Interrogating" 22). Brink's conception of historical narrative as dialogic and mutable is demonstrated in varying ways in the three texts discussed above. In each, an exploration of historical 'truth' reveals constructions rather than 'facts', and demonstrates that our understandings are resolutely narratorial. An understanding of history as a narrative process allows for the disjunction between an ideal unbiased, unblemished 'truth', and the rendition of experience in semiotic terms.

The return to the seminal myth of first contact in The First Life of Adamastor addresses the prejudicial narrative of otherness while simultaneously providing an alternative perspective by which to understand engagement of this kind. Its interrogation and undermining of the mythology of otherness underpins black/white relations in all historical contexts in South Africa and is therefore relevant beyond the specifically colonial period in which the novella is set. The examination of this myth has implications for a number of subsequent myths including appropriation of the land and its peoples and the oppression of non-white peoples. The text's redemptive project, in which both black subjects and their homelands are historically renegotiated, provides a model by which other prejudicial and preclusive renditions may be similarly redressed. Despite various problems associated with such 
characterisation, the text succeeds - at the very least - in bringing issues of historical narrative to the fore and in providing opportunity to consider various associated problems as outlined above.

Likewise, Devil's Valley explores issues surrounding the narration of history and deals specifically with the subsequent implications of mythology surrounding colonial contact. In this case, the mythology denies the miscegenative ancestry of the Afrikaner community, privileging the valley's inhabitants as an exclusive and superior race. Undermining both racial and male superiority, the text addresses two of the central tenets historically used to justify and condone the oppression of nonwhite and female South Africans. In critiquing these myths Brink's text threatens the very foundations of prejudicial and oppressive practice in the nation. Deconstruction of the mythical is also, inevitably, deconstruction of the ideological frameworks which determine and govern social and political behaviours.

Finally, A Chain of Voices draws together the various subversive and dominant voices of the other texts. Adopting a multitude of perspectives, the novel's narrators enact historical process, reflecting the ways in which history is experienced, interpreted, censored and inevitably defined. The reader is encouraged to compare the various testimonials with the court findings and is thus implicated in the teleological process of historical production. An awareness of the reader's partiality is central; Brink's mandate is to interrogate both the positions of others and most crucially, one's own.

The three texts under discussion represent not merely alternative versions of history but are primarily concerned with the manner in which mythologising and remythologising operate as historical and ideological processes, in which various perspectives are at play. They suggest, as does Mark Freeman, that "the meanings one arrives at are in some sense as much made as found" (30). In response to preclusive practice, Brink reveals alternative narratives beneath official or traditional accounts and thus problematises the 'truthfulness' of official record. In 
foregrounding the processes behind any historical account, Brink demonstrates the teleology inherent in all historical narratives. These three texts offer versions absent in traditional accounts of history. Further, the novels enact the processes by which history is determined and recorded. Each forces the reader's involvement in a process of judgement, in which manifold versions are compared and the search for the 'truth' is undertaken. Playing on the reader's expectation of, and desire for, resolution, the form and content of the novels work to encourage the reader to make a choice, to decide: Brink notes, "the point is precisely that it is not a matter of preference but of comparison: by engaging with the manifold versions that become available, the reader is able to make an informed and, above all, contextual choice in response to the needs of a specific set of circumstances" ("Reimagining the Past" 57). Brink suggests that the 'correct' reading is always situationally correct, rather than finally correct. Thus, the expectation for convergence of reader and implied author is not absolute except insofar as these two positions are similarly situated. The reader is forced to adopt the role of judge and to experience historical process as the arbitrary imposition of order and coherence on random events. S/he is also encouraged to recognise her/his own positionality - one of partiality. Finally, s/he is made aware of the ongoing possibilities for historical renegotiation.

In the wider context of Brink's work, his demonstration that all history is not merely narratorial, but intentionalist, is crucial. In each text, there is a mandate to attend morally, with the implicit suggestion that, when forced to do so, the reader will make the morally correct choice. Implicitly, the texts suggest that the choice of truths must be made in terms of a moral framework. Brink suggests that texts which challenge historical accounts "prompt the reader to assume a new (moral) responsibility for his/her own narrative, as well as for the narrative we habitually call the world ("Interrogating" 23).

The implied suggestion that the reader will inevitably make the 'correct' moral choice is significant. It suggests not merely that a 'correct' choice exists, but that the author, the text, and/or the characters have access to this version while others 
remain unenlightened - again, the dissident/liberal position appears privileged. The assumed authority attached to such positioning is clearly problematic and is an ongoing concern in these texts as in the oeuvre as a whole. The texts are, however, redeemed, at least in part, by means of various literary devices which undermine both the historically sanctioned account and also the alternatives provided. A focus on narratorial uncertainty, exposure of the prejudices, misunderstandings and misinterpretations of both narrator and narrated, continual reassessment of central narratives and interrogation of both original and counter-mythologies provides some ongoing critique of both the sanctioned account and the various possible alternatives. It is in this continual interrogative process, I suggest, that the value of Brink's historiographic works lies. The process mirrors that by which history is imagined, determined and endorsed but also reflects a similar process by which it may be renegotiated - in this way, the focus on a past age is also, importantly, a debate concerning the present and the future. Most crucially, however, it is the process itself, rather than the product, which teaches that history is merely a series of culturally and politically determined myths by which one responds to the world. The core of Brink's liberal initiative, therefore, is not his proficiency in subverting oppressive renditions of historical narrative, or offering a flawless alternative model, but rather his mastery in revealing the framework behind professed 'truth(s)', including his own. In an essay discussing postmodernism in South African literature, Brink concludes: "what I have offered [...] is one side of the coin; what matters is neither this side nor the other, but the coin" ("South Africa" 489). 


\title{
CHAPTER 9
}

\author{
An Act of Terror \\ and Violence as Protest
}

Amandla! (Power!)

Ngawethu! (To the people!). 
Many of Brink's texts express a latent concern with an imagined future apocalypse. This impending revolution is the focus of much South African literature of the 1980s. The threat of the black other is often envisaged in terms of a revolution; the nonwhite inhabitants of the nation will rise up against the outnumbered whites and usurp their power. Crucially, it is assumed that black activists will be responsible for such reactionary violence. As I have suggested, this fear of the imminent violence of the black other has historical precedents but ignores any threat posed by the many white activists who also challenge the policies of the apartheid state from within its power structures.

A brief outline of the political and social contexts of this time is central to understanding the tone of the era and the roles played by dissidents of all racial categories. As is noted in An Act of Terror, the events at Sharpeville in 1960 marked a turning point in the resistance movement. This watershed came to symbolise the culmination of decades of oppressive practice, years of unjust and violent treatment at the hands of the authorities - state-sanctioned police brutality, unjust imprisonment, corporal punishment, torture and murder. Increasingly frustrated by both the relentless violence of the state and its moves to quell any form of political protest - of which the banning of persons, texts, meetings and organisations are examples - many resistance groups were prompted to armed resistance. After Sharpeville, the decision to form a new dissident group, Umkhonto we Sizwe (The Spear of the Nation) in 1961, symbolises this movement away from peaceful protest. The decades from 1960-80 indicate a significant increase in politically subversive activity and in authoritarian counter-measures. In 1966, President Hendrik. F. Verwoerd, the ultimate symbol of apartheid rule, was assassinated (an earlier attempt on his life had left him merely wounded), an event which undermined the complacency and security of the white regime. The exiled ANC, once advocators of peaceful protest, eventually conceded to the inevitability of violence. In 1985, the group's President Oliver Tambo stated, "I fear that [racial war] is not only coming but already here. We will fight and we will expect a blood bath" (qtd. in R. Conrad Stein 85). If not an 
outright declaration of war, Tambo's statement reveals the extent to which violence had become central to the political situation in South Africa.

The issue of violence is central to Brink's An Act of Terror (1991), to debates surrounding the contemporary political situation of apartheid South Africa and the future direction of the nation, and to my examination of these. Some primary questions are raised in this regard, each of which is described and interrogated in Brink's texts. The motivations and justifications for violent acts are crucial: how, and in what circumstances, ask the novel's characters, may violent acts be rationalised and justified? Again, my examination moves into familiar territory, a concern with the basis by which morality is evaluated. The text encourages the reader to consider these issues, to decide whether reactive violence - violence in response to prior oppressive and unjust acts - is fundamentally different to the violence of an oppressive state. This is perhaps the key question in An Act of Terror: who is the terrorist, the state or the dissident? Further, who defines terrorism? If there is a difference between state violence and its subversive counterpart, where does the difference lie? On what basis is one form of violence evaluated as immoral and another as just? Again, the basis on which the moral merits of a particular course of action are judged is central. One is foreed to consider - as Brink's characters must whether reactionary violence is merely the continuation of a violent cycle, or if it serves some other 'higher' purpose? In each of these questions there is a latent concern for the future of the nation.

A concern with the power of non-violent forms of protest underlies this consideration of the efficacy and morality of violent insurgency. The power of representation - in speech, art and literature - is implicitly interrogated. This novel cycles back to a recurrent theme in Brink's work, to an exploration of the role and effect of art in politically and socially contentious environments. Specifically, the reader is prompted to consider whether art is an effective subversive tool, or merely an avoidance, on the part of the artist, of engagement in the politics of her/his time. Again, the reader returns to the debates of revolutionary rhetoric in which peaceful 
protest is opposed to the ostensibly more committed and powerful stance of the saboteur. In this respect, the novel implicitly interrogates its own role and effect: here, Brink retains an awareness of the tenuous positions of his various characters while simultaneously critiquing his own authorial stance.

In An Act of Terror, the issue of political resistance is imagined in terms of an Afrikaner liberal, Thomas Landman, who acts (violently) against his own people and their leader. This representation has a basis in fact. As I have suggested, any threat to the apartheid regime was not posed solely by the black quarter; white activists also challenged prejudicial and oppressive state policies. Examination of the issues surrounding the violence of oppression and consequent counter-violence is then extended to include the viewpoints of a variety of racial, gendered and political representatives - including those of both 'oppressed' and 'oppressor' and some who do not fit neatly into either category. The protagonist is a variation on earlier Brink characters whose employment involves the investigation and revelation of the realities of the South African political and social environment. A freelance photographer, or visual recorder, Thomas shares earlier protagonists' desires to increase awareness of the horrors of the apartheid regime and, specifically, the current State of Emergency in which the novel is set. "How else", he asks, "would the world find out what is happening?

The novel begins immediately prior to an act of sabotage in which Thomas is involved. Planning to assassinate the State President, he and his lover and fellow activist, Nina, discuss the impending event and review their reasons and justifications for their stance. In the context of the novel as a whole, the failed attempt on the President's life is significant only as a means to explore the motivations and reasoning behind such extreme acts. Therefore, the text is essentially an examination of issues of morality; the manner in which it treats political loyalties, nationalism, treachery and guilt is secondary to this primary interrogation. More specifically, the text is a record and an interrogation of various debates surrounding violent resistance to an oppressive state. The novel delineates the intellectual, moral and ethical bases 
on which Thomas' decision is justified and the various debates for and against active, armed resistance. Multi-narratorial perspective aids in encompassing the spectrum of views in regard to (specifically violent) political activism. The protagonist's metaphorical journey traces the various aspects of these debates. Thomas first renounces armed protest as an effective subversive tool, then becomes convinced of its efficacy and is actively involved in a 'terrorist' attack which results in many deaths, before ultimately concluding that violence simply prompts further bloodshed. In this respect, the text is cyclical, progressing through the various options for the dissenting South African before finally returning to the stance of non-violent protest Thomas originally endorsed.

A chronicle of Thomas' ancestral history appends the novel proper, endorsing the non-violent ideal he ultimately adopts. Written by Thomas after the failed assassination attempt, this genealogical record traces a history of oppression and the various responses - ranging from passivity to violent retaliation - to that oppression. Thus, the chronicle enacts the varying possibilities and consequences available in unjust environments. Each of these possibilities reflects on the decision made by Thomas in the novel itself (60) and on the implications of that decision. Inevitably, the supplementary text is coloured by Thomas' new-found abhorrence of violence and interprets the family's - and, by implication, the nation's - history as a cyclical movement in which violent acts are avenged by further violence and the result is merely increased bloodshed (e.g. 709).

\section{Defending Violent Protest}

"Killing: so that the killing might stop. That is why"

(Brink Terror 89).

In The Wall of the Plague, Andrea wonders, "What is judged in the end: the act, or its motivation?" (270); this question is one of the central concerns of An Act of Terror and also one of the key bases by which the South African context is examined. 
There is no doubt that the oppressive regime in which the novel is set is undesirable and should be undermined - from the outset of the novel, the critique of the state and its leader, the President, is both overt and scathing (11) - but how can this protest be launched without causing further oppression? In order to explore this question further and engage with the themes addressed in the novel it may be helpful to provide a brief overview of the range of viewpoints and, specifically, the justifications given for the need for violent subversive acts. Maria's revelation as to the nature of the political realm in which she lives is relevant in this respect, providing a framework against which violent acts may be examined and understood. She asks: "What does our own - 'civilised' - history amount to other than a catalogue of violence? Through what else, if not violence, does our Christian country maintain its law and order?" (173). Putatively, the violence by which the state's prejudicial and unjust policies are policed and enforced is a given, a standard by which any retaliatory or revolutionary violence may be compared and assessed. Notably, the members of the subversive and unnamed organisation to which Thomas and Nina belong re-define a conventional understanding of terrorism, establishing a distinction between activism and terrorism. Activism, they argue, refers to the actions of a committed and subversive force, established to undermine the oppressive and unjust practices of a totalitarian regime. In contrast, the state represents the terrorist, the perpetrator of violent, unjust crimes on its innocent victims. In this vein, the conventional expectation concerning the relevance of the novel's title is inverted the title refers not to 'terrorist' acts such as those in which Thomas and the Organisation are involved, but instead to the actions of the oppressive regime. The text's overt critique of the apartheid regime and its representatives - including the State President himself - is further supported by this redefinition of 'terrorism'. The Organisation redefines terrorism; the text as a whole, however, urges the reader to recognise the relative nature of such definition. Erik points to this relativity, suggesting that terrorism, like any other abstract concept, depends on perspective (536). Thomas also realises that "What is a 'terrorist' in one part becomes 'hero' in the other; the 'law and order' of the one becomes the 'subversion' of the other" (500). 
Thus, the morality of an act is inextricably tied to the position from which that act is judged. This acknowledgement is central to the following discussion.

\section{Cyclical Violence}

“isn't it our own pious Boer Calvinist government

who first introduced violence as part of the whole system?

It's easy always to expect the 'opposite side' to renounce violence,

while we keep on using it ourselves"

(Brink Terror 499).

Criticism regarding violent means of protest invariably focuses on its effect. Specifically, it is suggested that violence is self-perpetuating, a claim reinforced by the cyclical effect of violent acts and counter-violence enacted in the family chronicle. Thomas' uncle, Oom Boet, recognises this ceaseless cycle, noting, "once you start using violence to change the world to your liking, you're stuck with violence to keep it going. And then there's no way out again" (157). Later, Lisa, the novel's representative pacifist, makes similar claims, suggesting that in using violence to right wrongs, one merely destroys everything, including any possibility of a new start (597). She argues that, because violence is a battle for power, it results in the replacement of one oppressor with another (480). Thomas fails to convince her that, rather than attempting to replace one group with another, they are merely trying "to get rid of a small corrupt all-powerful clique so that people can decide for themselves how to run their lives" (480). In an environment in which the majority of the population is suppressed by means of institutionalised violence, how can any effective change be made? It is unrealistic to expect that the oppressor will renounce violence when the method has been such an effective means of control. The only means of challenge to such a regime appears to be retaliatory and violent. And yet, there is also recognition that such a reaction may merely worsen an already untenable situation. 
It is also a commonplace to suggest that a violent response to state oppression is merely a vengeful act. The activists of the Organisation in this novel, however, assert that the armed struggle is not retaliatory - in the sense that it is not motivated by anger or revenge - but is instead a political tool designed to undermine the enemy. Justin, one of the activists involved in the bombing, tells Nina, "You don't throw bombs in anger, Nina. You do it because you've thought it right through and decided on the best strategy. You don't throw bombs with your heart or your guts, you do it with your head" (49). It is claimed that the attempted assassination is neither "cathartic violence" nor "retribution" (50), but rather a carefully considered and calculated strategy in the war on oppression. Any decision to act violently follows a period of introspection and is ostensibly considered only when all other methods have been exhausted. Violent protest is deemed a valid - putatively the only - means to protest versus the unjust and oppressive actions of the apartheid state. Thomas' own self-justificatory rhetoric centres on the belief that violence will undermine the oppressor to such a degree that ultimately negotiation will replace violence: he notes that he and Nina "recognised that there are situations where doing nothing may be worse than exploding a bomb and killing people. In order to prevent more violence" (402). In demonstrating the extent and effect of their power as a revolutionary force, the group hopes to undermine the complacency of the regime and, by instilling fear, push for negotiated change. The state's fear of apocalypse will ostensibly ensure a more peaceful future (599-600).

The defence for armed resistance, to which Thomas and his fellow activists appear to subscribe, centres on their willingness to sacrifice their own lives for the cause. The act of violence against others should not, they suggest, be viewed merely as an attempt to harm or eradicate the enemy. Thomas' acceptance of the fact that he and his compatriots may be sacrificed is proof, it is implied, that they act for the greater good, rather than with a view to usurp the power of the state in favour of their own. Mandela's famous words are invoked to support this claim: Nina muses, "How did Mandela put it many years ago? - 'It is an ideal I hope to live for and to achieve. But if needs be, it is an ideal for which I am prepared to die". She claims, "This is 
what sustains me. This knowledge inside myself. That I'm not sending, in cold blood, others - 'innocents', that charged word - to their deaths, but that I am prepared, if I must, to give up my own life" (89). This willingness to offer the ultimate sacrifice of one's own life apparently nullifies the possibility that one may also commit murder and represents a moral loophole by which otherwise untenable acts are justified.

\section{Black Dissent}

\section{"Violence our language"}

(Brink Contrary 235).

For many of the activists, violence is considered the only choice. The standard justification for the Organisation's policy of violence is that given by one of its members, Sipho: "The Organisation didn't choose violence for ethical or humanistic reasons, but because after fifty years of peaceful protest we had no other option left. And because it was effective" (47) - rhetoric which echoes that of Mandla in The Wall of the Plague (432-3). For the disenfranchised and therefore politically muted non-white population, violence becomes a means of articulation, a language which will be heard. For black activists, in particular, lack of choice is a standard complaint. Thomas suggests, "don't you think [...] people can be driven to a point where there is no other option left, nothing except violence, if they really want to change the world?" (167). Further, when forced by a fellow Afrikaner to state whether he favours violence, Thomas accuses him, "You can afford to reject violence $[\ldots]$ because you are the right colour. You're on the right side of the fence. All the power of the state is at your disposal" (135). Later, when told that "Violence has no place in the mind of any rational being", Thomas responds, "For you, violence is a philosophical concept, [....] Or a moral one. If you were black, you might discover that it is the only way to stay alive" (135). Sipho's understanding of violence is central, especially in respect to non-white South Africans. He suggests, "one cannot talk about violence as if it was some 'topic for discussion', a theme, a theory, a 
modus operandi. You can only talk about it if you know what it means, if your own body bears the scars of it. Because violence is not an abstraction" (438). In Africa, he explains, Sisyphus is black, and "His task is not metaphysical but social. His task isn't suicide but murder" (439). This is because evil cannot be thwarted with passivity, but must, according to this logic, be challenged with force. He believes that to attempt to overthrow political and military power with moral superiority is futile, as such an appeal relies on morality and goodness in the oppressor characteristics he believes the oppressor lacks. He concludes that it is not enough to condemn the oppressive state; one must actively challenge it (439).

In each of these variations on a theme, it is suggested that there is a lack of choice, no (effective) alternative but to adopt arms. The implication here, as in much of Brink's literature, is that the position of the oppressed is a special case allowances must be made for the oppressed that could reasonably be denied to the oppressor. Thus, it is implied that the evaluation of moral and just acts is relative. Specifically, the distinction between the 'moral' violence of the activist and the 'immoral' violence of the state is derived from a consequentialist line of argument. The morality of such acts is not derived from the means, but rather the ends. One set of ends (e.g. God's law, racial purity, social stability) is compared against another set (perhaps justice, equality, dignity). Clearly, for non-white South Africans under the apartheid regime, legislative means of control are severely restricted. Arguably, in this situation, the disenfranchised may be granted some moral latitude for otherwise untenable - here violent - acts.

However, one might ask how this flexibility in the evaluative or judgmental process alters when the roles of oppressor and oppressed themselves change or are renegotiated. Who decides where morality ends and immorality begins? Further, where does the white dissident reside on such a scale? Does s/he reside with the 'moral' oppressed, with whom s/he has chosen to stand, or with the 'immoral' oppressor whose privilege s/he shares? An awareness of this philosophical dilemma is evident in the text itself. Nina, in particular, realises the difficulty in assessing 
moral worth. When Thomas claims, "We know what we're doing is the right thing. The necessary, inevitable thing. It's the only moral choice", she replies, "I'm sure that is exactly how Judas argued. Or do you think it only depends on which side wins in the end? Morality can't be as provisional as that" (38). In Brink's texts, and in this novel in particular, morality is deemed a provisional, mutable term. The various definitions of morality rehearsed in the text - centrally those of the various dissident positions as opposed to that of the oppressive state - illustrate that one's understanding of moral acts is relative. However, as in previous texts, An Act of Terror ultimately chooses a moral position and endorses that stance in preference to all others.

The plan to assassinate the President is intended "To demonstrate the vulnerability of the system" (50), to shock the Afrikaner community out of its complacency and comfort. Notably, Thomas' involvement in the resistance movement does have this effect. Thomas' sister, Maria, is prompted to action; she claims, "It is only doing something about it that really matters. I think I am ready for it now" (175). Likewise, Raymond/Kholisile, a hitchhiker Thomas offers a lift to, decides to become a freedom fighter after his association with Thomas (186). Erik, Nina's brother and a member of the army, is also motivated by Thomas' commitment, and soon joins the Organisation. However, in contrast to the reactions of Maria, Raymond and Erik, a young man named Hennie, previously reluctant to undergo his stint of compulsory military service, is prompted to fight on the border, to protect the nation from 'terrorists' such as Thomas (300). Thus, in various ways, the complacency of the various people surrounding Thomas is undermined. This ripple effect, in which one action creates an ongoing reaction in others, is interesting when compared to the tenor of Brink's earlier novel, The Wall of the Plague. The earlier text concluded with Andrea's decision to return to South Africa, to join the resistance and act against the apartheid regime - Paul, too, decides to actively oppose the apartheid government. Each of these characters represents the ripple effect of which Maria, Erik, Raymond (and Hennie) become a part. The overriding ideal, in both novels, appears to be that individual action causes a chain reaction, a 
groundswell of small, individual actions which will gradually effect change. Again, hope for a better future resides in the individual and the call to action is a challenge, to each individual, to create ongoing, small but significant change. Thus, Brink's texts encourage action, but reject its more violent form.

\title{
Choice
}

\author{
All I know is that when it comes to violence \\ there must always be another option. \\ Otherwise we are forced to renounce whatever it is \\ - however little it is - \\ that makes us different from the animals"
}

(Brink Terror 583).

Just as the call to action is an individual one, so too is the responsibility associated with that action. Earlier, I suggested that the position of the dissenting oppressed represents a moral dilemma. Oppressed by violent means, s/he is apparently given only one option - to retaliate in a similarly violent way; while acknowledging that this retaliation will almost certainly perpetuate a cycle of violence, the subjected individual sees no alternative. The dilemma appears irresolvable, and yet Brink's text does offer some small suggestion of resolution this hope lies in individual choice. In a manner similar to that posed in The Wall of the Plague, this text suggests that every individual has a choice - a choice to be oppressed or to resist that oppression, ${ }^{119}$ a choice to act peacefully or violently and so forth. The possibility of choice, Fanon suggests, is what characterises the human condition. Therefore, the use of an apparently justificatory claim by the oppressed, in which s/he states that s/he has no alternative but to act violently, is revealed as bogus. While peaceful resistance may not be considered an effective choice (by the Organisation, for example) it is still a valid alternative to violence. This distinction

\footnotetext{
119 This may be summarised as a choice between philosophising (represented by Sartre and Marcuse) and action (represented by Fanon and Guevara).
} 
between a lack of choice and the rejection of available choices due to their undesirability or putative inefficacy is key to both the novel and the apartheid South African situation which it reflects. The justificatory claim that there is no alternative choice avoids any responsibility for the decision made. In contrast, if one acknowledges that other choices exist before making a decision, a sense of responsibility is acknowledged. The central concern here is that this responsibility be assumed and borne. With responsibility, it is implied, comes moral action.

Brink's own dissident challenge is launched through his literature, espousing a rebellious but peaceful dissent against the oppressor; his novels may potentially incite violent acts, but they are in themselves non-violent. Over the course of his oeuvre, there is a focus on the role and effect of art as a subversive political tool. Unremittingly, Brink's texts interrogate both the regime but also, implicitly, dissident positions. Latent in each of the texts is a recurring question: to what extent may the artist affect the unjust and prejudicial realm s/he critiques? ${ }^{120}$ Inevitably, this interrogation leads to a consideration of alternative subversive models. In earlier novels - A Dry White Season, Rumours of Rain, The Wall of the Plague and others the examination extended to active political resistance, first on an individual basis and, later, in collective, organised groups such as the one imagined in An Act of Terror. In this latest novel, however, the exploration turns to a concern with armed resistance, specifically. Interrogating the various possibilities for dissident action, Brink's texts suggest that, rather than the action itself, it is the will behind that action which is of the greatest significance. Although the novel's protagonist ultimately rejects violent resistance as a valid and effective tool of challenge, his compatriots are not condemned for their actions, but rather the reasoning behind their decisions is interrogated and found to be inadequate. An Act of Terror implies that it in a process of self-interrogation and in one's acknowledgement of individual responsibility that morality lies. As in all of Brink's work, this 'solution', if it may be termed that, is not without flaws. By linking a sense of morality to an individual sense of responsibility, this relativisation creates problems when any collective sense

\footnotetext{
${ }^{120}$ This question will be examined more fully in chapter ten.
} 
of morality is required. For legislative purposes, for example, a consensus is surely necessary to ensure that immoral and therefore criminal acts may be legislated against, policed and punished. Again, the ideal is inadequate in any practical terms. What is achieved, however, is a useful investigation of the many facets of the debate surrounding action and inaction in the South African context, particularly in relation to the ostensible need for armed resistance. In On the Contrary, the narrator states, "There are two ways by which men can come to honour. One is the way of Letters; the other the way of Arms" (348). Although Brink's works explore alternative possibilities, ultimately the way of arms is rejected in favour of the way of letters. 


\section{CHAPTER 10}

Accusations of Misrepresentation and Appropriation:

Female Representation in A Portrait of Woman as a Young Girl, Imaginings of Sand and The Other Side of Silence

"it was not my place"

(Brink Rights 172). 
An emphasis on the prejudicial treatment of racial others characterises Brink's literature during the apartheid years; however, in his post-apartheid works Imaginings of Sand (1996), Devil's Valley (1998), The Rights of Desire (2000) and The Other Side of Silence $(2002)^{121}$ - there is a distinct shift in focus. This thematic transition in Brink's works parallels the political transition of the nation. Prior to the first democratic elections in 1994, the nation existed in an "interregnum", 122 a period of indeterminacy and expectation in which hope for a better future focussed on the possibility of a new, more equitable, government. A landslide victory on the part of the ANC in the 1994 elections meant the inauguration of the first 'black' government and the abandonment of the last vestiges of racially prejudicial policies. Subsequently, hopes for a new and less violent regime mingled with feelings of fear in respect to an uncertain future. At pivotal historical moments such as this, writers are prompted to consider the future, both in terms of subject material for their literature and in terms of their role as artists. Clearly, there was opportunity for the literature of the time to imagine a way forward, to envisage a peaceable and equitable future society and to consider how this may be achieved. Likewise, there was scope to engage with the problems related to such significant political and social change. These issues are central to Imaginings of Sand and The Rights of Desire; in each text, the future possibilities of the nation are considered and hopes and fears for the future outlined. $^{123}$

A second theme, however, is more overtly pursued in all of Brink's postapartheid novels, including the two which return to earlier historical eras - Devil's Valley and The Other Side of Silence. Despite a newly 'democratic' mode of government in South Africa, the oppression of the nation's gendered others remained an ongoing concern. The nation's historical and social narratives remain patriarchal and men continue to make the decisions which affect the nation. Post-apartheid,

\footnotetext{
${ }^{121}$ The novels have been classified as 'post-apartheid' by means of their original publication dates. As Devil's Valley has been discussed in detail in chapter eight, and offers little more in terms of female representation than the other novels discussed here, I will not analyse it further.

${ }^{122}$ The term is a Gramscian (Marxist) one, used by Gordimer to outline the period of transition from racial oppression towards the possibility of democracy (Brink "Nadine Gordimer" 266).
} 
these silences, Brink suggests, "invite exploration" ("Stories" 30). Developing a thematic thread latent in his earlier works - e.g. An Instant in the Wind and The Wall of the Plague - Brink's post-apartheid novels delve deeper into the situations of female South Africans to explore a particular (gendered) mode of oppression. In a post-apartheid nation, Brink claims, he "can now portray women's experiences without feeling that the main struggle is somehow being ignored" (Keenan, qtd. in Kossew "Reinventing" 122). This new focus may be described as a further 'rebirth' in Brink's work. In this respect, Brink's oeuvre conforms to Gordimer's claim that "Art is on the side of the oppressed" ("Essential Gesture" 291): newly enfranchised and empowered non-white South Africans must fend for themselves while Brink's fiction turns to those still denied an effective voice. This distinctly feminist treatment of the South African situation will remain the focus of this chapter.

Related to this discussion, a consideration of the (specifically dissident) writer's role and responsibilities is central. In apartheid South Africa, dissident writers such as Brink have operated in a state of moral "siege"; post-apartheid this position must be reassessed. I will therefore briefly consider the writer's arena in a changing political and social environment - for which the post-apartheid milieu provides a fitting example - and engage with representational politics. Concerns as to whether a male, privileged member of the Afrikaner establishment has the ability or, indeed, the right, to speak of or for another - whether racial or gendered - have been implicit in each of the preceding chapters. In this chapter, I will address this issue, specifically relating it to the representation of women, but referring also to literary representation per se.

${ }^{123}$ These issues will be discussed further in relation to The Rights of Desire in the conclusion to this thesis. 


\title{
Speaking of/for the Silenced ${ }^{124}$
}

\author{
"Our craft is all in reading the other: \\ gaps, inverses, undersides; the veiled, the dark, \\ the buried, the feminine; alterities" \\ (J. M. Coetzee White 81).
}

"The writer's primary engagement", Brink asserts, "is with silence" ("Interrogating" 14). This silence is the "meta-text" of the contemporary South African novel of which J. U. Jacobs speaks, a silence which signals "the unavailability of a central portion of South African experience to narrative configuration" (39). Acknowledging the occlusion of these experiences, but refusing to accept their "unavailability", Brink argues that it is the artist's responsibility to respond to the enforced silencing of oppressive regimes. He encourages a constant process of $u n$-forgetting and $r e$-membering, using the fictional process to imagine the experiences of otherness. These originally 'erased' histories include restoration of the experiences of females, blacks, coloureds and homosexuals.

Such representation, however, poses a number of problems. In The Wall of the Plague, Paul considers how to approach the writing of Andrea's narrative, conversing with her in his imagination: "The only way I can possibly do justice to you is to try and imagine what it's like to be you. But does this also predestine failure? - how can I, how dare I presume to form you from my rib?" (446). The first concern - "how can I?" - relates to the impossibility of accurate representation, the fear of misrepresentation; while the second - "how dare I?" - concerns fears of appropriation, the misuse of the representational role. In essence, misrepresentation refers to an inadequacy in instances where women are spoken of, while the accusation of appropriation refers to attempts to speak for women. Further, Paul suggests that the role of the artist, or creator, is inevitably tainted by authority.

${ }^{124}$ This section draws on material originally prepared for my Masters Thesis, "Shouting Against
Silence: André Brink's Voices of Truth" Dixon, "Shouting against Silence: André Brink's Voices of 
In chapter three, I identified Brink's mandate to investigate the unknown and forbidden other who lies beyond selfhood. Here, the other is not prohibited by decree of prejudicial and segregational state policy, but rather by the restrictions of representational politics, precepts which inform artistic representation. How, one must ask, may a writer adopt a valid position from which to speak of (or for) another? Further, does such adoption of another's position silence the other or - as Brink claims - give voice to an otherwise marginalised group?

As I have intimated in earlier chapters, Brink's position as a white male South African speaking of/for racially and gendered 'others' is problematic in the terms described above. Kossew describes the dilemma of appropriation as the "messy involvement of the narrating voice in the very structures it is seeking to subvert" ("Resistance" 22), pointing to the inevitable 'taint' of the narrating self in depictions of the other. She summarises Cherry Clayton's accusation that the representation of alterity from a position of 'whiteness' is almost certainly 'a 'speaking for' rather than a 'speaking of'", given that the narrating voice is inextricably tied to, and narrating within, the power structures of whiteness ("Resistance" 25). In these terms, "white writing' specifically is viewed as a further example of "colonialism's territorial appropriation of land, and voice, and agency", a claim originally made by Stephen Slemon (qtd. in Kossew "Resistance" 21). As previously subjugated groups are granted the freedom and the means to speak for themselves, the position of the white liberal writer becomes more tenuous, her/his interventions 'on behalf of' less necessary (or desired). Is the appropriative voice of the empowered writer, therefore, a necessary evil - a means by which the other may be heard until s/he is granted voice? Or is the taint of appropriation so severe as to negate any value attached to granting voice to those otherwise silenced? Brink's constant representation of both racial and gendered others suggests that he asserts either his right or a need to cross boundaries of gender and race in a literary realm. ${ }^{125}$ It is implied that this need

Truth.".

${ }^{125}$ Notably, these are significantly intersecting/overlapping categories. 
overrides the inevitably problematic nature of such an appropriative act.

Further problems of misrepresentation surround the issue of homogenisation. Brink claims that he may now focus on "women's experiences" (Keenan, qtd. in Kossew "Reinventing" 122) but generally fails to distinguish between these various women, either in his original statement or in his texts. Kossew argues that, despite many "positive and reconciliatory tendencies" in Brink's model of feminism,

its emphasis on a shared experience of gender oppression, while seeking to incorporate white women into history, is itself complicit in eliding differences between the experiences of white and indigenous women, thus replicating rather than resisting the exclusionary practices of South African historical discourse. ("Reinventing" 123)

This putative elision of female experience into one 'type' suggests not solely a stereotypical understanding of female characters and experience, but perhaps also an archetypal one. Perhaps the intention behind such representation is to ensure the archetype is represented, in order to simplify, and thus more clearly identify, the central issues under examination in the novels. If Brink's characters - both male and female - are understood as archetypes, rather than stereotypes, in their exhibition of a select number of characteristics, the delimiting nature of this group of traits again has unfavourable implications in terms of representing either selfhood or otherness. In particular, the white male Afrikaner archetype falls into two distinct and dichotomous archetypal categories, each of which ostensibly excuses his involvement in the oppression of non-white, non-male and/or non-Afrikaner groups. $\mathrm{He}$ is either identified by his epiphanic new-found awareness of his oppressive role, concomitant with a willingness to atone for these past sins or, alternatively, by his continued selfjustifying belief in the regime in which he is implicated.

Whether understood in archetypal or stereotypical terms, in Brink's work physical signifiers identify femaleness, in particular, in specifically sexual terms, associating womanhood with sexual vulnerability and the ability to be appropriated. Ironically, while attempting to be inclusive in his work - representing all groups and 
types of people - Brink actually negates such individuality. Therefore, whether Brink's characters are understood as stereotypical or archetypal, I concur with Kossew's criticisms as to the elision of female experience. The problems associated with Brink's representation of his female characters - whether in terms of appropriation or, more particularly, misrepresentative homogenisation - detract from what I have claimed is an otherwise convincing interrogation of patriarchal renditions of South Africa's history. Whether it is possible to represent otherness, without the taint of authority which the self represents, remains one of the central debates in the artistic realm.

So far, I have introduced issues surrounding the representation of otherness by the empowered - a position which reflects Brink's own status during (and arguably beyond) the apartheid regime. However, a consideration of issues of authorial responsibility must also extend to writers beyond the privilege and empowerment Brink experiences as a white, male artist. If one extends suggestions made in the previous chapter - in relation to the morality of black revolutionary violence - to this issue, the position of the subjugated artist may arguably be viewed as exempt from such critique. Again, my discussion returns to a concern with an evaluative model by which the actions of the oppressed and the oppressor are judged. As I suggested in the previous chapter, in much of Brink's literature there is evidence that the position of the oppressed is considered a special case $-\mathrm{s} / \mathrm{he}$ is privy to allowances denied the oppressor. This moral and ethical relativity is interesting in relation to Brink's own defence of his literary role, specifically in relation to his representations of othemess. In the previous chapter, I asked where does the white dissident reside on a relative scale in which the oppressed is ostensibly exempt from criticisms related to the oppressor? Most importantly, in the context of this chapter, what does this positioning mean in terms of the permissibility and scope of literary representation of otherness? The (specifically dissident) artist, it appears - like the oppressed - has special licence but must still act with moral and ethical integrity. 
And what of the previously subjugated and newly-empowered subject? As I asked in the previous chapter, how does this flexibility in the evaluative or judgmental process alter when the roles of oppressor and oppressed themselves change or are re-negotiated? If the position of the oppressed is indeed a special case, then what is the position of the newly-empowered artist whose recent enfranchisement promises that her/his previously silenced or ignored voice will suddenly be heard? Is this artist now newly responsible for acts of representation? In effect, is s/he now required to operate under the same moral and ethical frameworks by which past oppressors have been judged - a judgement from which s/he was previously exempt? Must s/he now assume some responsibility for representation, or is the right to speak of otherness now revoked? A common aspect of all these questions is whether the representation of otherness is solely the domain of the subjugated.

Brink's decision to focus on women's issues is problematic. As I have noted, Brink's post-apartheid literature largely abandons racially oppressed groups and focuses instead on those oppressed in terms of gender. This shift in focus, while beneficial in foregrounding women's rights, also allows the author to avoid addressing one of the central questions concerning post-apartheid racial others. Earlier, I discussed the arguably 'righteous' role of the oppressed (specifically in terms of the oppressed artist), suggesting that, in the terms described by both Gordimer and Brink, the oppressed have special artistic licence. I raised questions as to the manner in which this role must alter with the withdrawal of oppressive practice after apartheid. Will artists of this type now be denied the immunity they previously enjoyed, and be held newly responsible for their artistic representations? In turning his attention from racial to gender oppression, Brink avoids consideration of this issue. Rather than remaining with the formerly oppressed and tracing their transition, Brink instead transfers his concerns to a female arena and the question of the newlyempowered (artist) remains unanswered in subsequent works.

Likewise, Brink's rendering of the voices of historically silenced 'others', like 
those of other racially- or gender-empowered writers before him, is of concern. His crossing of both gender and racial boundaries raises questions concerning his authenticity and right to speak on behalf of others. Criticism related to (authorial) appropriation permeates contemporary literary theory. Rosemary Jolly warns of the danger for the post-colonial novelist "in assuming access to the historical, native subject and his desire" (52). The appropriation of voice, she suggests, is a colonising or violent act, one in which artists usurp the rightful roles of women and slaves. Criticism related to speaking from a position other than one's own is twofold; it concerns issues of misrepresentation and appropriation. These two interrelated aspects of representation will provide a framework by which to discuss Brink's novels and the implications of his work.

Seemingly, literary artists are entrapped by the apparently irresolvable politics of representation - whether they represent or avoid representation of otherness, they are condemned. However, Tzvetan Todorov offers a possible solution to this dilemma, claiming that "one does not let the other live merely by leaving him intact, any more than by obliterating his voice entirely [.... Heterology, which makes the difference of voices heard, is necessary" (250, 251 qtd. in Parry 152). The idea, Parry explains, is based on Emmanuel Levinas' model of "commerce with alterity as a contact taking place in an intersubjective space where the non-identity of the interlocutors is respected and retained, and which leaves both 'I' and 'you' separate and intact but enhanced" (152). The idea of intersubjectivity is central. However, one must ask whether such an ideal - "commerce with alterity" - is possible, and how it is to be represented without appropriation of the other.

In an essay entitled "Speaking in Voices", Brink discusses the creation of $A$ Chain of Voices and confronts issues of appropriation, defending his right to speak on behalf of otherness. First, he claims that to deny an author the opportunity to explore another identity is to impose on her/him the same limitations as those enshrined in an oppressive system such as apartheid. He asserts that distinctions between self and other - whether in terms of race, gender or other divisions - are "artificially imposed 
barriers" which may be crossed (17). Further, he claims that his (imaginative) knowledge of friends and colleagues of other races makes it possible for him to vicariously experience "some essential ingredients of the specific conditions termed by others the 'black' or the "white' experience" (17). He concludes, "[i]t may be more presumptuous to exclude all exploration of the Other than to attempt the hazardous act of discovering in the Other the humanity you share with him or her" (14). It is implied that this imaginative stance is not merely the realm of the artist, but, ideally, should be shared by all members of society. Brink claims,

If the reader is invited to enter into an encounter with the text by those elements in it he can relate to because of their appearance of familiarity (man recognizing woman in terms of previous experience and of convention), the full relationship with it develops because of the challenge of the unfamiliar, the new, the strange, the defiance of this text which resists immediate consummation (the unknowable properties, the otherness of this person). ("Literature and Offence" 123)

In imagining the situation of otherness, he suggests, one experiences the pain of the other and may be prompted to end the exclusion, or segregation, by which the other is defined.

In various essays, Brink responds to criticisms relating to the appropriation of voice, claiming that he acts merely as a medium through which voices of the past may speak or be imagined. Referring to the original legal documentation which formed the basis of $A$ Chain of Voices, he notes that the voices of the accused

"were there, speaking to me: speaking, indeed, across a divide of a hundred and fifty years, but speaking in their own voices, telling their own stories, exposing whatever truth of their tortured lives they could grope at: and in this case, to have ignored their voices in favour of either silence or a Whites Only interpretation of the event, would have been [...] an obscenity. ("Speaking" 17-8)

Further, he suggests his desire was "to allow, as far as possible, the 'authentic voices' of slaves from the past to speak within the apartheid world in which I wrote" 
("Introduction" to Reinventing 12). Thus, he counters criticisms of appropriation with claims as to the noble purpose of granting voice to historically silenced subjects - it is considered a more acceptable alternative to traditional renditions which assert the white view. Problematically, he indicates that the responsibility for the narratives lies with the original speakers, rather than with his imaginative representation of them.

In order to fully address the many questions I have raised in relation to representation, it is necessary to consider the exact nature of acts of representation. Invariably, critique centres on the manner in which representational acts are appropriative. However, Wenche Ommundsen's examination of acts of representation includes a caution against assuming representation is inherently appropriative. She clarifies, "[t]he verb 'to represent' is generally understood to mean to 'stand for', in other words to symbolise something which is absent. But to represent also means to 'make present', to somehow restore the absent object to the mind and the senses" (32). It is my contention that this restorative aspect of representation is where its value lies: if one is to understand representation as a redemptive process - as Brink appears to - rather than as a static and authoritative act, much of the critique surrounding appropriation may be refuted. Therefore, if the charge of appropriation is to be defended, it is crucial to examine the manner in which such representations are rendered in Brink's works.

As I have intimated in previous chapters, the struggle to articulate othemess is a crucial aspect of Brink's imperative to redress the injustices of his environment. However, Brink's oeuvre has incited a barrage of criticism surrounding his representation, much of which centres on specifically female characterisation. Critique of this kind accuses the author of misrepresentation, claiming that in Brink's work the female subject is inadequately and/or incorrectly characterised. Arguably, characterisation of the other is stereotypical, and effectively reinforces the prejudicial view each text ostensibly aims to denigrate. Whether Brink's focus on feminist issues in the post-apartheid novels is, as I have suggested, a response to the political enfranchisement of the racial other, a response to the criticisms of his peers, or a 
combination of the two, is redundant. What is important is that Brink's works indicate a sustained attempt to engage with gendered others and to address the specific problems of female experience.

As I will argue, there is much to criticise in this regard - many of these criticisms also extend to the representation of racial others. Despite these significant shortcomings, Brink demonstrates a willingness to explore the contours and experiences of otherness and to convey this in fictional form. His sustained efforts to do so demonstrate courage and tenacity, qualities evident in all of his works. Further, there is some evidence of development, in terms of representation, in his latest work; the central character moves further away from stereotypical and prejudicial representation. While female representation remains a central concern in his oeuvre, it appears that the author is moving closer to the subtleties and complexities of characterisation which would arguably benefit his work. Given the textual evidence thus far - in terms of the constant reinventions which characterise his work - it is my prediction that this development will continue in Brink's work and that his characters will become increasingly complex, moving beyond the stereotypes in which they are currently entrapped.

\section{A Portrait of Woman as a Young Girl}

"Look at me, I am naked,

I am clothed in shadows and light;

[...] I am exposed and quite vulnerable"

(Brink Portrait n. pag.).

In order to address questions of misrepresentation and appropriation specifically, it is necessary to provide a brief overview of the representation of women in Brink's texts and of the problematic nature of such representation. The aspect of most concern relates to the stereotypical nature of Brink's female characters. Over the course of the oeuvre, the majority of primary female characters 
are defined in overtly sexual terms. Depiction of this kind reflects Brink's own positioning as a male viewing the (female) other in largely sexual terms and adds little to the descriptions of his female characters. Brink's collection of predominately nude photography, A Portrait of Woman as a Young Girl (1973), provides opportunity to introduce (visually) some of the more problematic issues related to the literary representation of women in his novels. Clearly, the collection of photographs of mostly nude women is remarkable in the context of the political and social expectations of the era in which it was published. During a time of increasingly stringent censorial impediments to artistic expression in South Africa, the photographs challenge the moral boundaries of the time. The manner in which the text was surreptitiously published is indicative of these restraints and of the legislative enforcement of social and moral boundaries: Buren Publishers released a limited edition of 500 copies. ${ }^{126}$ Clearly, both author and publisher were wary of the probable response to the text's contents.

The overt nature of the nudity in the collection both refutes and, paradoxically, reinforces traditional Afrikaner notions of the purity and sanctity of womanhood. The first photograph selected for discussion is indicative of the first section of the collection, entitled "Afternoon of a Nymph", which comprises a series of images of a naked child in various natural environments. The inclusion of a flute, which appears in a number of these images, suggests the mythical element emphasised in the accompanying text in which the girl is described as a "nymph" and likened to a "flamingo or little doe" (n. pag.).

The image invites discussion of Brink's problematic representation of women in that it reflects the manner in which women are frequently depicted in his literature. Many of his female characters are described in terms which reflect their vulnerability and sexuality. His female protagonists are invariably described as childlike, with figures which tend towards adolescence rather than adulthood. Invariably,

\footnotetext{
${ }^{126}$ Due to the limited availability of this text, a selection of photographs has been reproduced, with the permission of the author. This selection is discussed as representative of the whole.
} 
descriptions of women focus on their sexuality rather than their personality, with their anatomical particulars described in detail.

The stereotypical representation reiterated in Brink's fiction is also reflected in the photographs of this collection, particularly in the first section. Notably, Brink's subjects are usually turned away from the viewer or, alternatively, seemingly oblivious to the viewer's gaze (as in the first and second photographs reproduced here). This, combined with the young girl's nudity, places the viewer in a voyeuristic role, an uncomfortably intrusive perspective in which the subject is seemingly denied any opportunity to refuse 'permission'. Even in examples where the subject looks towards the camera, it is my contention that the viewer's gaze remains voyeuristic as the subject appears too young to give informed consent as to the manner in which she is posed and photographed.

The text which prefaces section one of the collection reinforces the stereotypical and idealistic rendition of women found in Brink's texts, his frequent insistence on their innocence and the suggestion that they are vulnerable to the sexual exploitation of males/viewers/readers. In terms of both text and image, Brink flirts with a line between the innocence of a young child and the sexuality of an adolescent female subject. Thus, the section raises questions as to the sexualisation of youth and is problematic in feminist terms.

Section two, which invokes the title of the collection, "A Portrait of Woman as a Young Girl", commences with commentary similar to that preceding the first section. However, the photographs are more mature in terms of both composition and technique. Here, the human form is not merely posed, but studied. Spanning a variety of adult subjects, the section includes examples of both nude and clothed women and a number of inanimate objects. Figures three and four demonstrate the photographer's creative use of photographic techniques. Here, Brink employs methods which add dramatic effect to the photographs, underscoring the beauty of the subjects' forms. Likewise, innovative technique is exhibited in figure five; an 
abstract patterning over the image obscures the specifics of the female genitalia while simultaneously emphasising the beauty of the subject's form. In each of these examples, representation of the subject is clearly more subtle and complex than that of the pre-pubescent subject in figure one. Figures three and four frame the women not merely as nude, but as examples of human form juxtaposed against the delicate fronds of a fern and web-like cracks in glass, respectively. There is little discomfort for the viewer, as the subjects face the camera and are clearly of an age to give their informed consent to such representation.

In the examples discussed, and throughout the collection as a whole, Brink demonstrates dramatic use of light and dark and of the framing of the subject. There is also clear indication of a development over the course of the collection: images which focus less on the nudity of the model and more on photographic technique and the interplay of light and shadow have more visual impact and aesthetic appeal. Unfortunately, although Brink has exhibited an intention to develop his literary representation of women, the subtlety found in the last three figures chosen for discussion remains - thus far - elusive in his literature. In his literature, Brink appears unable to move beyond the mythological and stereotypical views of womanhood represented in his earlier photographs.

The first stirrings of an ongoing search for alternative means of representation are evident in these photographs and yet, ironically, in this collection Brink both challenges and reinforces the patriarchal authority of the apartheid state. Attempting to challenge traditional representations of the purity and sanctity of women, Brink permits the viewer a more intimate relationship with the subjects, beyond certain prescriptive boundaries. Further, the images are experiments in different modes of representation, as are rehearsed in his fiction. However, as I have noted, this representation is inherently fraught with the same ideological, prejudicial and genderist concerns found in more traditional images. I will consider this paradox further in respect to his novels. This collection of photographs stands as an early engagement with artistic representation and provides illustrative counters by which to 
discuss Brink's later literary endeavours. The literature engages with issues of representation and articulation from a variety of perspectives, attempting to discover more adequate means of representation. Therefore, Portrait of Woman as a Young Girl may be upheld as an early example of Brink's ongoing struggle to represent the other, a conflict most clearly problematic in terms of female otherness.

The central concern in relation to Brink's female characters is that they are represented predominantly in terms of a (highly-sexualised) "male gaze". ${ }^{127}$ The term suggests the same problematic relationship between the viewer and the represented as is evident in Brink's collection of nude photographs: the subject's vulnerability is juxtaposed with the power of the viewer/photographer in a binding and potentially oppressive relationship. In this unidirectional power-play, the female subject is depicted solely in terms of benefit to the (male) viewer. As feminist theorist Laura Mulvey suggests in her discussion of cinematic representations of women, "the representation of female bodies and characters [...] are subordinate to the desperate meaning-making procedures of the masculine subject" (summarised by Nick Mansfield 97). Mansfield notes that, in Mulvey's terms, "woman functions [...] not as a category of living people, but as a representation alone, whose function is to reassure or encourage the subjective self-definition of masculinity" (Mansfield 97). The description of cinematic female characters as "representational" is crucial: whether in cinematography or literature, stereotypical female subjects arguably parade a set of characteristics which are inevitably limited by the requirements of male subjects.

Brink's female characters exemplify this type of sexual objectification, enacting the select set of (sexual- and gender-stereotyped) criteria by which the literal and figurative virility of the male may be co-defined. They remain steeped in patriarchal assumptions in which femaleness equates to either weakness, submission and sexually availability or voracity, sexual aggression and promiscuity. In framing the female protagonist - and, by inference, the male protagonist - in this way, Brink

\footnotetext{
${ }^{127}$ This claim is made independently by Vassiliki Kolocotroni and Olga Taxidou (46).
} 
arguably perpetuates, rather than undermines, the oppressive practices of the prejudicial society he ostensibly critiques. Such representation demonstrates the author's own pre-conceptual prejudices regarding the gendered other and his inability to deny his own entrapment in the self/other dichotomy which he attempts to critically undermine. Clearly, Brink's attempts to speak of women are equally as problematic as his attempts to speak for them.

Consideration of the characterisation and role of sexualised females in Brink's work must also include examination of the correlative role of the sexualised male. Speaking of $A$ Chain of Voices, Jolly critiques Brink's depiction of the male/female liaison:

the fiction itself participates, albeit subconsciously, in the practice of male domination, which is such a pervasive feature of the society it attempts to depict $[\ldots .].[\mathrm{T}]$ he women gain their recognition through their service to men. Their 'independence' $[\ldots]$ or in literary terms, their differentiation as characters, is ultimately dependent upon their allegiances to the men of both races whose action determines the central conflict of the novel. (48-9)

Her critique includes the claim that "the figure of the outcast Bet, trying in vain to get back into the favor of the narrative by persuading Nicolaas to recognize her submission to him, can be seen as emblematic of the only position afforded women by the exclusive structure of the narrative" (52). Clearly, "male domination" of the female is inherent in this text and persists in many of Brink's others; whether it is "subconsciously" participating "in the practice of male domination", as Jolly suggests is, however, debatable. I have intimated that any critique of representation must include consideration of the role and responsibility of the artist. Therefore, in order to adequately examine Brink's representation of women I will conjecture as to the intention and function of such representation.

The depiction of subjugated women is not necessarily an endorsement of this practice. It may be argued that instances of "male domination" are part of a literary tactic in which women are objectified in order to encourage the reader to recognise 
and acknowledge their oppression. Given the manner in which such scenes are described, and the larger novelistic context in which they appear, this would appear to be the case: the oppression of women is included as a reflection of societal practice but is not endorsed, but instead implicitly critiqued. Hester's protests against the denial of female identity in the patriarchal fictional heterocosm, for example, foreground societal objectification of women in the text: "[n]o one will think of liberating an ox or a horse. You can only bother about liberating a slave if you think of him as human. So how do you expect men to think of slaves in that way if they haven't even discovered that women are human yet?" (259). The entrapment of women in the patriarchal confines of the society in which they live is thus exemplified and gives context to depictions of women such as Bet who begs Nicolaas to oppress her. It may be concluded, therefore, that Bet's position is indicative of the represented societal objectification of women, rather than the author's. If read in this way, the objectification of women in the text forms part of Brink's critique of such prejudice, a critique with which the reader is invited to concur. Granted, the inclusion of this type of material must be managed well, as the reader may 'misread' or ignore the cues by which such female subjugation is critiqued, but the textual evidence clearly identifies a feminist purpose in this case. A postscript to an essay entitled "Speaking in Voices' reinforces my claims, suggesting that the intention of such depictions is to interrogate and examine, rather than to perpetuate prejudicial actions. Brink states:

[t]he crucial question concerns power relations $[\ldots$.$] there is a difference$ between men's appropriation of femininity in order to strengthen their own authority and their attempt to question masculinity through adopting a feminine position in the system of sexual difference; and the same would apply to a white writer speaking, in a racist society, in the voice of a black. (20; original italics) 


\section{Imaginings of Sand - Speaking for women ${ }^{128}$}

"There's the monuments for the ages;
ours, at most, the imaginings of sand"

(Brink Imaginings 332).

Brink's concern for the plight of South African women is explicitly addressed in his first post-apartheid novel, Imaginings of Sand. The text follows Kristien Müller as she returns from a state of self-imposed exile, travelling to South Africa to the bedside of her dying grandmother. Kristien's return to her abandoned homeland forces her to renew her acquaintance with her family and her nation, and to acknowledge her own troubled identity as a South African woman. Set immediately prior to the first democratic elections in South Africa in 1994, the novel also traces the uncertainty of a nation on the brink of a stupendous social and political transition detailing, in particular, the violence of this historical moment. This setting also provides opportunity to consider the role women have in this context and in a future society.

Crucially, it is the promise of narrative which prompts Kristien to return to her homeland and these female narratives foreground the text's thematic - specifically feminist - concerns. When Kristien's sister, Anna, telephones to say their grandmother is critically wounded after a terrorist attack, she urges Kristien to return, saying, "she has stories to tell you" (12). These tales have always been an integral and binding factor in the relationship between Kristien and her grandmother, Ouma Kristina. Kristien has been chosen as a receptacle for the narratives of her female ancestors. Representing the collective memory of eight generations of a matriarchal lineage, this counter-history or herstory is a series of fantastical and contradictory tales in which memory and history are constantly under revision. The stories invert traditional patriarchal accounts in which women are "sidelined by history" (98) and

\footnotetext{
${ }^{128}$ For further discussion in this vein concerning Imaginings of Sand see Dixon, "Shouting against Silence: André Brink's Voices of Truth.".
} 
"condemned unheard" (Miller 33). Ouma's counter-narratives, her memories and her imaginings thus fulfil "the need to record and bear witness", expressed by Brink ("No Way out" n. pag.), utilising language and narrative as weapons against the enforced silence of othemess. Brink declares, "[t]here lies a peculiar satisfaction in countering the tactics of secrecy with exposure: the dark fears nothing quite so much as light" ("Introduction: A Background" 35).

This idea is emphatically linked with notions of nation building, through purgative recollection, by Krog: "[s]torytelling brings freedom from the past, healing, reconciliation and an end to the silence" (219-20), a claim of particular relevance in a newly democratic nation. Notably, the notion of writing and/or articulation as a response to silence describes Brink's own relationship with the South African censorial regime in which his literature has operated, and is evidence of the manner in which voice has begun to counter enforced silencing in the post-apartheid nation as a whole. Arguably, voice in the artistic, political and business realms is now the right of all South Africans, and is the means by which both personal and collective notions of nationhood can be developed and expressed. However, Brink intimates that women's voices remain unheard.

For the first time in Brink's oeuvre, the challenge to the dominant discourse and its narrative claims is voiced exclusively from a female perspective. Earlier texts flirted with the notion of female narrators or focalisers, but female perspectives are either not sustained (as in The Ambassador and An Act of Terror where the narration is multi-narrational or An Instant in the Wind where the narration is shared), or ultimately revealed as filtered by a male narrator (as in The Wall of the Plague). ${ }^{129}$ In contrast, Imaginings of Sand consists of an (imaginative) series of female narratives, each of which is filtered through the female protagonist. These stories putatively resist the linearity, singularity and closure of a patriarchal master narrative. Commenting on the novel, Brink notes, "I [...] attempted a subversion of male 
historiography and linear genealogy by transforming dominant historical discourses into the inventions of the (female) imagination" ("South Africa" 489). These imaginative narratives act as symbolic representations of the voices of all those silenced by dominant discourses. The exploration of personal and collective female identities and their constitution in narrative also comments on discursive identity formation in other groups (both dominant and oppressed).

\section{Privileging or Problematising of Female Narratives?}

"Let's keep the men out of this.

They came with verse and chapter.

Our story is different, it doesn't run in a straight line"

(Brink Imaginings 174).

In order to redress the historical oppression of women, Brink foregrounds, and tends to privilege, the female view. However, this prioritisation of women's narratives is problematic in many respects. First, the foundation of these narratives on a series of gender-specific clichés invites accusations of misrepresentation. In Brink's portrayal of the novel's central female characters, the mind of the female is viewed as fluid and all-embracing, as is her narrative, and she is characterised as mystical and esoteric, "drawing on a formidable store of accumulated knowledge, female and arcane" (337). In contrast, the male model of history is seen as a linear, 'factual' record of events, a rendition which presumes male rationality. This is a relatively common set of claims articulated by many writers and theorists; essentially, masculine thought and writing is opposed to feminine. In a further cliché of the female condition and of women's responsibilities to motherhood, the women of the novel nurture the narratives, carrying them within them, as they would bear a child, until ready to pass the burden on to the next generation. Thus, the question must be asked whether Brink's text merely serves to invert the traditional binary opposition in

${ }^{129}$ Robert Plummer suggests, however, that the 'ventriloquism' of The Wall of the Plague continues in Imaginings of Sand, in that the author speaks for the female, but fails to speak about her. The latter 
which the authority of the male is dominant while maintaining conventional gender assumptions. Do the gendered clichés in the novel in fact undermine such an inversion? If the latter is the case, then binary inversion must ultimately be viewed as an unsatisfactory means of challenging relations of power and authority, yet no alternative model is offered. Again, the representational debate returns to questions of misrepresentation.

I have suggested that the matriarchal myths are an inversion of a binary opposition, in which the original patriarchal model is overthrown in favour of a matriarchal one. This is also problematic in terms of representation, inviting criticisms of reverse prejudice and raising questions as to the validity and sustainability of inverted authoritarian relationships. Toril Moi critiques this type of inversion which "runs the risk of becoming an inverted form of sexism. It does so by uncritically taking over the very metaphysical categories set up by patriarchy in order to keep women in their places" (13). This favouring occurs in Brink's texts despite Brink's own mandate to maintain plurality and therefore equality. The tendency illustrates the dangers inherent in revisionary endeavours based on the reversal of existing power structures: an inversion of a dominant discourse must itself be challenged in order to avoid becoming oppressive. While Brink appears to promote such ongoing truthful contestation, in fact he often stops short, privileging previously silenced 'voices'. Seemingly, the female narratives contest not only the patriarchal rendition of history, but also each other: like the titular imaginings of sand, the matriarchal myths are constantly shifting, resistant to any attempt at fixity. Thus, the truth of any individual version is undermined, just as the patriarchal understanding of history is. However, collectively, the matriarchal model of history is inherently favoured over that of the patriarchal, endorsed as a more inclusive and truthful historical model.

It can be argued, however, that rather than offering a new dominant discourse, an inversion of gendered relations of (narrative) dominance has several primary and 
inter-related objectives. The inversion undermines the current master narrative, revealing its authoritarian stance as arbitrarily constructed and upheld. Further, provided that the inversion is not foregrounded as a fixed alternative to the current dominant discourse, it can be seen to function as a marker, filling the position of authority momentarily, in order to suggest the possibility of alternatives to current power structures. Simultaneously, the temporary positioning of matriarchal discourse as an alternative to that of patriarchy demonstrates the inherent dangers in replacing one mode of authoritarian discourse with another. The next stage in the resistance to authoritarianism must be an acknowledgement of the undesirability of any singular master narrative, and the need for a more diverse and pluralist model. Inversion is, therefore, merely the initial stage in a continual challenge to dominant discourses. It is the ongoing nature of such discursive challenges that, I argue, Brink emphasises in his claims to a narratorial truth which undermines - but does not replace - the official version. As he himself argues, "if anything may be invented, why should any one particular invention carry more weight than another? If all is text and there is nothing outside the text, how can anything be morally or historically valorised?" ("Reinventing a Continent" (Revisiting History) 23). Interestingly, Brink’s work never fully exemplifies this radical level of contingency.

In her discussion of Imaginings of Sand, Kossew criticises Brink's apparently paradoxical claims, critiquing the manner in which he posits the novelistic form as "the perfect vehicle for rewriting history while, at the same time, drawing attention to the fictionality of both discourses". She raises concerns as to the manner in which the narratives in Imaginings of Sand are posited as "healthier alternatives" to the official version but are never in themselves interrogated ("Reinventing" 116). As I suggested above, Brink ultimately favours his narrative model over the traditional record of history. He does, however, point - to a greater or lesser degree in various novels - to the similarities in fictional and historical narratives in order to demonstrate the mutable nature of each and to counter any suggestion that his fictional accounts are more authoritative than the official version. Arguably, it is not the narratives themselves he favours, but rather the narrative model by which history may be 
related. In using an overtly mutable narrative model, he exposes the same processes at work in official counterparts and undermines their claims to veracity.

Imaginings of Sand does not merely write back against the silencing of otherness, but also discloses the manner in which any narrative is informed both by its inclusions and its exclusions, its presences and its absences. It is in this respect that one may counter criticisms as to the ostensible 'privileging' of female narratives and the problems associated with an inversion of the patriarchal model. Imagery related to astronomy suggests the extent to which presence is defined by absence. Jacob Bonthuys is curious about the nature of black holes and asks Kristien, "[i]f you can't see them, then how do you know they're there?" She replies, "I read in a book that it's like a man in black clothes who dances in the dark with a girl in a white dress. You see only the girl, but from the way she dances you know the man must be there" (243). Repeatedly, the correlative relationships between absence and presence, or silence and sound, are foregrounded in this novel. In insisting that the reader remain alert to the formative or signifying nature of absence, the text offers not only a protest against singular narratives such as those of traditional patriarchy, but also challenges the simple inversion of any such dominant narrative. Without such an injunction to ongoing contestation, Imaginings of Sand would itself become merely an inversion of traditional historical narrative: the dominant discourse would merely be replaced by the previously subjugated one. Crucially, inversion must only ever be the first stage in an ongoing process of challenge from counter-discursive voices. In this respect, the problems associated with historical privilege, evident in Imaginings of Sand, are defendable.

In her exploration of female narratives, Kristien narrates a symbolic journey of self-discovery in which the historically silenced and exiled may regain personal and collective identification through ancestral memory and imaginative narrative. Although restrained by the problematic nature of the author's representation of female subjects, the often conflicting narratives of Brink's text represent an alternative historical model which grants representation to historically marginalised 
females. In respect to this text, Brink's feminist focus is arguably an effective counter to the patriarchal marginalisation of the gendered other. Brink's critique of the manner in which narration is utilised as a mode of enforced silencing is countered by his demonstration of its ability to militate against such dominance and reclaim both female voice and narrative.

\section{The Other Side of Silence}

\section{"Here is only silence, a silence of distance and of space"}

(Brink Other 3).

The Other Side of Silence encompasses many of Brink's central themes, and may be discussed under a number of (arguably arbitrarily categorised) topics. Specifically, the text is a further example of Brink's concern with the remythologising of history, the countering of historical silences with new narratorial perspectives and imagined stories. For this reason, discussion of this text may have been accommodated in the chapter dedicated to that subject. However, rather than discussing the novel as a further example of the inversion of patriarchal history, I have chosen to focus specifically on the representation of women and of feminist issues in this text and the implications of these. The novel's explicit engagement with feminist concerns provides opportunity to make some summative claims in the context of the oeuvre as a whole.

The Other Side of Silence may be described as an imagined (at times phantasmagorical) biographical account. The text traces the life of a woman identified merely as Hanna X, a German orphan and later settler in German SouthWest Africa. The unnamed narrator's fascination with the name he discovers in historical records prompts him to create an entire history for Hanna. The life he imagines is one of abuse and oppression; Hanna is victimised by all, but most specifically by the men with whom she is associated. 
The physical depiction of Hanna is one of the most interesting aspects of this novel, in that it demonstrates an attempt to move away from some of the stereotypical aspects of Brink's previous female characters. Hanna is described as physically 'ugly', both before and after her physical mutilation. In contrast to the parade of attractive and therefore physically desirable women in previous texts, Hanna is unique. The impact her physical characteristics have on the politics surrounding gender relations is crucial and a comparison between her treatment before and after her physical mutilation is revelatory. Prior to her disfigured state, Hanna is described as ugly, (with the exception of her hair), and yet she is still sexually 'desirable' to the men who take advantage of her. After she is beaten, however, the manner in which men react to her is substantially altered. She is rejected as a suitable sexual partner, a rejection which both protects her and yet is also hurtful. If Hanna is indeed ugly prior to her mutilation - as the characters who describe her suggest - then the desire men experience for her is not in response to a physical attraction, but something more insidious. Crucially, the desire is framed in terms of a wish to dominate rather than unite, a desire which arguably pertains to all self/other relations, but which is explicitly foregrounded in this case. If the relationship between Hanna and her oppressor is understood in these terms, then there is no need to demonstrate further dominance over her after the attack, as she bears the physical (and permanent) signs of her victimisation. Thus, Hanna's 'lack' of physical beauty shifts the focus from the sexual implications of the interplay to the power which drives such domination and submission. Therefore, not merely is Hanna's physical unattractiveness a deviation from Brink's norm, but it also aids in foregrounding the gender politics at play in inter-gender relations.

Despite the ostensible movement away from stereotypical female representation described above, the sustained focus on Hanna's physicality remains problematic. Arguably, ongoing exposition of the nature and extent of Hanna's 'deformities' - both prior to and after her attack - suggest a fetishistic relationship 
between the author and his subject, ${ }^{130}$ a relationship in which the reader is implicated. This fetishistic response operates contrary to any feminist resolve indicated in the text's thematic concerns. As in earlier texts, female subjects are depicted in terms of their bodies - they are bodies, rather than people. Despite some attempts to introduce motive, thought and feeling to the character of Hanna, the reader remains largely isolated from her character, except in terms of an intimate knowledge of her physical 'defects'. In respect to the female characters with which we are primarily concerned, this type of reader-character relationship endorses the notion of women as objects. Whether such denirtions are part of an attempt to expose this tiype of societcit objectification, or rather the unwitting result of an author unable to move beyond a prejudicial view of women, is unclear. What may be determined is that the depiction of women in terms of bodies endangers the feminist concerns of the text.

Clearly, this text deals with oppression in ways reminiscent to earlier Brink novels. As in Imaginings of Sand, however, the specific focus on women's oppression becomes central, rather than remaining secondary to the racial oppression explored in the apartheid novels. This specifically gender-based abuse is most powerfully portrayed in physical terms, in the beatings and physical mutilation of Hanna and in the various rapes and attempted rapes described. The way in which such physical domination correlates to more subtle forms of gender-oppression is obvious and need not be scrutinised. What is most interesting is the feminist response to such domination, the textual exploration of not merely the female experience, but also of the options available to women under such conditions.

The powerlessness of women in the specific social and political environment of this novel is clearly articulated. Various female characters complain that their lives are determined by the men with whom they are associated. Crucially, each suggests that she "has no choice" (197). Countering this assumption, Hanna claims that there is always a choice: echoing Andrea of The Wall of the Plague, and Kristien

\footnotetext{
${ }^{130}$ The inclusion of an implied author putatively distances the actual author of the text from any narratorial critique and yet ultimately Brink himself remains responsible.
} 
of Imaginings of Sand, Hanna proclaims that oppressed women have the choice to either submit, or to instead shout the defiant 'No!' of Antigone in the face of their oppressors. In Brink's text, this defiance is realised in two distinct ways: the first is (less forcefully) represented by the sexual rejection of men, and the second, by her commitment to revenge.

Hanna is the first of the novel's characters to reject men. From the initial platonic friendship with her former teacher Fräulein Braunschweig, to the specifically sexual relationship with her travelling companion, Lotte, Hanna appears to tum from men towards women. Relationships with women, it appears, are non-threatening in that they do not represent the roles of domination and submission inevitable in intergender unions. Problematically, her lesbianism seems prompted or determined by the brutal treatment she has experienced at the hands of men. Her sexual preference may be viewed as either a form of active rebellion against the sexually determined roles of women in a patriarchal society or, rather, an inevitable result of such oppression. Whether viewed as environmentally determined, or chosen, lesbianism is problematically deemed an unnatural state (in the sense that it is not arrived at organically). If understood in this way, Hanna and Lotte's relationship may be described as political lesbianism, in that they each turn to homosexuality as an alternative to the oppressive nature of female-male interaction.

The danger here is that, while the novel appears to attempt a restoration of female identity and worth, simultaneously lesbian identity is problematically represented. While the introduction of homosexual elements in this text may be viewed as a further development in Brink's work - a continuation of his ongoing quest to explore further realms of occlusion - the nature of this lesbian relationship appears framed in terms of political dissidence against a patriarchal regime, rather than as an opportunity to explore the silences which surround homosexuality itself. If the suggestion that lesbianism avoids male-female oppression is to be taken seriously, how does this work in practice? Thus far, an avoidance of self/other relations has been cited as the origin and perpetuation of prejudice - black/white segregation, for 
example, is posited in earlier Brink texts as detrimental to any possibility of understanding between racial groups, while interracial union is upheld as a counteractive. Here, however, Hanna avoids any suggestion of inter-gender union, reserving her affections for her own gender. ${ }^{131}$ While this rejection of the male is understandable from a psychological perspective, given the traumatic experiences she has suffered, the implications in terms of gender politics remain problematic. In the context of the novel as a whole, where female-male relationships are rejected, abandoned or destroyed, there appears little hope for the type of union encouraged in Brink's earlier texts. Equally, the stereotypical representations of oppressive males and dominated females are of concern.

The second form of defiance portrayed in this novel is active revolt, most specifically depicted in terms of vengeance. Like the sexual rejection of men described above, revenge is also framed in specifically physical terms. Hanna and her 'army' traverse the continent murdering soldiers who represent the domination and oppression of the patriarchal regime. Rebellion of this kind is also premised on the notion of Antigone's defiant 'No!' - a declaration lent ironic significance by Hanna's muted state. Inspired by the narratives of historical women who defied their traditional roles and their men - Biblical women (48), and historical figures such as Jeanne d'Arc (64ff) - Hanna too asserts her right of defiance. Denied voice, the women (and a few male tribal representatives) adopt an alternative means of articulation, that of violence. Previously ignored, they feel their violent actions will finally allow them to be heard. It is implied in the text that, in the act of revenge, each of the members of the army will regain their individual identities, in that they will finally be acknowledged. While Hanna recognises the ultimate futility of their actions, she focuses on the act of defiance, rather than the result: "I have no illusions [....] I know I cannot change the world. I just want to do something. To show that it is possible to say No" (221; original italics). Her decision is a movement from passivity to activity, the adoption of responsibility for her plight: "All my life things

\footnotetext{
${ }^{131}$ Kahapa, a Herero she rescues from impending death in the desert is a notable exception. Hanna develops a platonic relationship with this man as he poses no (sexual) threat: he too has had his
} 
have been happening to me. I cannot allow that to go on. From now on, whatever happens, I must be the one who makes it happen" (221; original italics). Like Andrea of The Wall of the Plague, Hanna recognises that she has the choice to remain subjugated, or to act against such submission. Whether in terms of rejection or violence, the female response to male oppression is inevitably physical.

The commentary above focuses on women's experience and feminist issues specifically, (speaking of women); speaking for women is equally problematic in this text. I spoke earlier of the dangers of narratorial 'appropriation'. Brink appears to avoid this problem by rendering his protagonist mute: "There is no tongue. Only a small black stub, far back" (9). Clearly, Hanna's speechlessness signifies the historical patriarchal occlusion of female experience. Notably, narration of events preceding the amputation of Hanna's tongue are described as memories, rather than chronologically and are therefore also interpreted, rather than voiced. It is in this context of muteness that the titular phrase - derived from George Eliot's Middlemarch - operates. The novel imagines a territory beyond silence, in which women's narratives may be heard and towards which Hanna and her silenced female compatriots journey. Arguably, Hanna's inability to speak may also be considered an attempt, on behalf of both the implied author and the author proper, to avoid speaking for, or (mis)representing the gendered other. In contrast to Brink's earlier Imaginings of Sand where the narrative was rendered in first person from the perspective of the female protagonist, in this text the author alters the relationship between narrator and protagonist, placing the experiences of Hanna at a remove from the narrating voice. The ostensibly third person limited omniscient narrative point of view in the novel is, nevertheless, limited almost exclusively to events, dialogue and thoughts experienced by Hanna - the exception is in the various interruptions of the implied author who muses on the creation of the narrative. Therefore, despite the third person narrative perspective, the only viewpoint in the fictional heterocosm is that of Hanna. In this way, although technically voiceless, Hanna is granted narratorial capabilities by proxy. Like J. M. Coetzee's subaltern, Friday, her muteness alters, but does not 
avoid the problems associated with representing otherness: the politics of agency remain of significant concern.

Arguably, Hanna's enforced physical silencing operates along lines similar to any other type of metaphorical or literal silencing, disallowing the (here gendered) other to speak for herself and instead allowing the appropriation of that right by the articulate. The relationship between the voiced and the voiceless is, however, significantly altered in Brink's text: in Foe, (black) Friday symbolises the silences unreachable by the (white) author; in The Other Side of Silence, however, the 'unreachable' otherness of the female is imagined and interpreted. Hanna's voicelessness means that she is granted voice only by means of interpretation: in the fictional heterocosm, Katja interprets for Hanna, while both the implied author and Brink himself interpret - indeed, manipulate - the rendition available to the reader. These various interpretative relationships re-enact the narration of otherness by the putatively authoritative oppressor - re-enactments which appear to perpetuate, if not endorse, the appropriation of voice. ${ }^{132}$ Simultaneously, however, the foregrounding of the interpretative process acts as a constant reminder that all representation is interpretative. Throughout the text, the process of invention is transparent, and the reader is constantly reminded of the representational medium through which Hanna's life is imagined. This deliberate transparency suggests both the author's sensitivity to the problems of representation and also his recognition that there is no way to completely avoid them: textual acknowledgement of these processes is the only 'answer' offered in this text. Again, Brink rehearses different methods of representation, while acknowledging the inevitable pitfalls.

The feminist tendencies in this text are evident. Clearly, Brink's postapartheid focus on women's issues is central: the text details not merely the experience of oppressed females, but also considers the various options to overcome such subjugation. However, the problems associated with an examination of the 
experiences and themes of (here gendered) otherness, remain. Most specifically, the author appears involved in a continuing search for a stance from which to represent female experience without further endorsing the objectification and oppression of women. The dangers of misrepresentation and appropriation remain, dangers acknowledged in the text itself.

\section{Writing of otherness}

"One thing is clear:

ours is a period when few can claim the absolute value of a writer

without reference to a context of responsibilities"

(Gordimer "Essential" 288).

The implied author of The Other Side of Silence states, "I believe more and more that as a man I owe it to her [Hanna] at least to try to understand what makes her a person, an individual, what defines her as a woman" (153). Given the textual evidence examined thus far, it appears Brink's mandate is also to attempt to imagine and understand the female perspective. Throughout the discussion in this chapter, I have argued that Brink's representations of gendered otherness remain problematic, both in terms of the specifics of stereotypical (particularly sexualised) (mis)representation and also in respect to a more general appropriation of voice associated with such acts. The former is a concern for individual instances of representation, the second, an issue pertaining to the rights of the artist per se. I contend that each of the questions regarding the artist's ability and right to speak from a position of otherness - whether gendered, racial or otherwise - revolve around the issue of the artist's role and responsibilities.

Earlier, I posed questions that encouraged consideration of the artist's moral and ethical positioning. I asked, should the rendition of black experience be the

\footnotetext{
132 Notably, Hanna's interpreter in the text is also female, a factor which ostensibly avoids the traditional narration of women's experiences by a patriarchal record(er) of history; the narrator,
} 
exclusive domain of the black writer, or the white of the white author? In the context of the preceding discussion, we may now extend this question to encompass the gendered other; should the articulation of female experience be exclusively the domain of female authors? I also asked if subjugated artists have special licence to speak of the oppressor without being subjected to the same ethical codes? These questions and others of a similar nature resound in any context where oppression segregates two or more distinct groups of experience. Ultimately, these issues remain under dispute. Gordimer, however, provides a useful framework by which representation may be discussed and critiqued. In response to the question as to whether white writers should write of black characters, she states:

I challenge my challenger to deny that there are things we know about each other that are never spoken, but are there to be written - and received with the amazement and consternation, on both sides, of having been found out. Within those areas of experience, limited but intensely revealing, there is every reason why white should create black and black white characters. For myself, I have created black characters in my fiction: whether I have done so successfully or not is for the reader to decide. What's certain is that there is no representation of our social reality without that strange area of our lives in which we have knowledge of one another. ("Living" 279)

She suggests that, while alterity is a significant and undeniable aspect of self/other interaction, there is also shared knowledge and experience.

Essentially, there cannot be an all-encompassing prohibition on representing otherness - this would result in the destruction of the fictional project. The literary artist, however, must be held responsible for this representation:

The creative act is not pure. History evidences it. Ideology demands it. Society exacts it. The writer $[\ldots]$ comes to realise that he $[$ sic $]$ is answerable. The writer is held responsible: and the verbal phrase is ominously accurate, for the writer not only has laid upon him responsibility for various interpretations of the consequences of his work, he is 'held' before he begins 
by the claims of different concepts of morality - artistic, linguistic, ideological, national, political, religious - asserted upon him. (Gordimer, "Essential" 285-6)

In Gordimer's terms, a writer's responsibility is twofold: a commitment to literature is twinned with a commitment to society. The writer's "essential gesture as a social being" - a phrase she borrows from Roland Barthes (no ref. qtd. 286) differs in various social and political contexts, Gordimer claims. In an oppressed society, the demand is first to speak for the oppressed and, second, to bear the state's punishment for that act. The 'responsible' artist in apartheid South Africa, therefore, is inevitably dissident: her/his responsibility to society is at least equal to, if not outweighs, that to art (Gordimer, "Essential" 289). The white writer, Gordimer continues, must endeavour to raise the political consciousness of the white group; for the black writer, the task is as composer of revolutionary hymns ("Essential" 293). For each, the essential gesture is a "revolutionary" one ("Essential" 296). It is also a mandate to tell the 'truth' at all costs (Gordimer "Essential" 294), "to describe a situation so truthfully ... that the reader can no longer evade it" (Berlin qtd. in Gordimer 299). Each of these considerations is equally relevant in terms of artists who speak for the gendered other. Throughout my discussion, I have signalled the necessity for an evaluative framework by which to judge concepts such as morality, truth and worth; Gordimer's model provides such a framework, and allows the reader to trace the development of a similar model in Brink's oeuvre. This evaluative basis is a central aspect of any defence against claims of either misrepresentation or appropriation: the intent of the representation is central.

Brink's proclaimed notion of the writer's role and responsibilities is closely aligned to that of Gordimer. Each considers the writer's primary responsibility to be the portrayal of 'truth'. In his seminal essay "Mapmakers", Brink compares the writer's mission to that of the mapmaker, charting territory deemed terra incognita by the authorities. He describes this role in terms which highlight the noble and revolutionary stance of the cartographer in a censorial environment. Despite threats 
of imprisonment, the cartographer continues in his work, meticulously redrawing the map, attempting to more closely represent the land he has explored. "Here", Brink claims, is the parallel of a "writer slaving away in his ceaseless attempt to draw the map of his vision of truth, risking his liberty in order to offer the world a new view of itself" ("Mapmakers" 167).

This idealistic conception, however, is challenged by literary critics Vassiliki Kolocotroni and Olga Taxidou who argue that Brink's conception of the artist is merely a further act of colonisation:

Brink's story fails to acknowledge that the explorer's lonely and misunderstood venture is a direct result of an historical process of colonisation; a fact which might help put in perspective his company's refusal to have the map drawn and thus offer its exploits to competition. More important, however, is the absence of any real or historical consideration for the actual land (including its people) which was there to be mapped; the assumption being that it exists as a result of its reconstruction by the cartographer. 'Refined' and 'enlightening' as it may be, this representation conceals and displaces an act of exploitation. The fact that in Brink's formulation, the map reflects the vision of truth of its maker, ultimately exposes the whole enterprise in both its actual and metaphorical sense as a self-glorifying appropriation. (44).

This particular form of critique returns us to the debate with which this chapter began, the questions of authorial misrepresentation and appropriation. Arguably, the 'truth' which Brink identifies in the cartographer's map is untruthful in respect to the colonised/oppressed peoples of the land he represents. Any version of truth, it appears, displaces a multitude of other contesting versions. In this respect, the examination of representation is also an examination of truth, of the validity of any one version of another.

Whether Brink's position as a white male writer speaking of/for the other is interrogated in terms of a colonial/colonised perspective, gender, or racial politics, or 
some other theoretical format, the implications of the inevitably dominant position from which he narrates are clear. The relationship between Brink as author and the oppressed groups he chooses as his narrative subjects is fraught with the pitfalls of representational politics. However, in the earliest chapter of this thesis, I identified the necessity of dissenting voices such as Brink's in a regime which negates the voices of the oppressed. His voice may be described in terms of proxy, dissenting against the oppressions of the regime until the oppressed may fulfil that role for themselves. Thus, I support Brink's right to represent otherness, provided that this does not preclude any opportunity for the other to speak on her/his own behalf accusations of appropriation, I believe, are largely invalid.

However, I remain concerned as to the nature of this representation, to the issues of (mis)representation outlined above. Any form of representation of otherness is defined by its inevitably interpretative nature, and thus flawless representation remains an impossible ideal. However, as I have detailed, there is significant room for improvement in Brink's representation of women, in particular. While Brink's novels suggest an intention to demonstrate and critique female oppression, in their specifically sexual representations they (arguably unconsciously) further endorse stereotypical and damaging views of women. The flaws in Brink's work are ostensibly balanced by his proclaimed intention to revisit such representation; like his metaphorical cartographer, there is an ongoing commitment to re-envisage and rework until the images mirror the reality he describes. As I have argued in terms of the gendered other, this intention remains largely unrealised. Despite an increasing number of central women who assert their power - Andrea in The Wall of the Plague and Kristien of Imaginings of Sand are representative - Brink's characters remain largely entrapped in the ideological frameworks of female otherness. Nevertheless, as fraught with problems of misrepresentation and appropriation as the literary process is, it remains an invaluable tool in imagining the experience of otherness and in considering means by which this type of oppression may be overcome. Given Brink's proclaimed resolve to continue to mirror the work of the cartographer in literary terms, I predict that future novels will further interrogate the state of gendered 
otherness and represent this femaleness in more subtle and less stereotypical forms. 


\section{CONCLUSION}

\section{The 'New' South Africa,}

The Rights of Desire

and

Before I Forget

"The white, as writer and as South African,

does not know his place 'in history' at this stage, in this time" (Gordimer "Living" 276). 
To label the era following the first democratic elections in South Africa postapartheid is clearly problematic. Crucially, both the new government and the nation as a whole continued to struggle with the after-effects of an oppressive regime and post-electoral euphoria soon dissipated. Despite an ostensibly newfound-freedom for non-white South Africans, many of the practical considerations of daily life remained largely unaltered. While the new ANC government attempted to progressively address South Africa's central concerns, the promise of a peaceful and prosperous nation - a hope which had inspired so many for so long - still remained a distant, future ideal. The frustration of black, white and coloured South Africans in this interim period was significant. In terms of a literary examination of this period, several central questions invite consideration. First, if the hope of a better future remains unrealised post-apartheid, how and when will this ideal state occur? Second, what role will white South Africans have under a new (black) regime? Perhaps most significantly, in terms of this exposition of Brink's work, questions surrounding the roles and responsibilities of (specifically dissident) artists continue to resound in a post-apartheid context. And, in terms of Brink's work, what does his cultural conversation amount to, what are its problems and how successfully have these been resolved? The two novels under discussion in this chapter provide a point of entry for consideration of these questions.

\section{The Rights of Desire}

$$
\begin{gathered}
\text { "From their excessive euphoria not quite five years ago } \\
\text { they now cannot find enough words to fulminate } \\
\text { against everything that has gone wrong" }
\end{gathered}
$$

(Brink Rights 261-2).

The Rights of Desire is a diffuse novel and, for this reason, is difficult to discuss in any meaningful way in relation to the central themes I have identified in Brink's work. The novel is, however, useful as a means by which to reflect on the earlier novels, and to make some summative claims about the development of the 
oeuvre as a whole. In one respect, the text may be described as a love story of the type attempted, and ultimately abandoned, in States of Emergency. Simultaneously, the novel depicts a post-euphoric age almost five years after the first South African democratic elections described in Imaginings of Sand, and details a nation finding its way, seeking answers for its many troubles. Arguably, it is this mood of despondency, the tone of uncertainty in both personal and social terms, which results in the diffuse nature I have identified. Brink's tendency to confront the problems of his age continues in this novel; however, because of the immediacy of the issues identified, possible solutions remain particularly tentative and largely unclear. Essentially, the text may be described as a twofold examination. The personal exploration pertains to the male Afrikaner protagonist, Ruben Olivier who symbolises a once-privileged group. In a post-apartheid context, Ruben represents those whose position of power has been usurped, a now dying order; the imagined apocalypse of earlier novels has occurred. The social examination concerns the nation as a whole, and reflects a society for which the promise and hope of a newly democratic future has become tarnished. The juxtaposition of Ruben's past memories and contemporary events provides opportunity to reflect on the transition from one historical age to another, in both personal and social terms.

The return to a white male perspective in this novel is of particular interest in the context of Brink's cultural conversation, specifically as it pertains to a postapartheid nation. Although the text treats, inter alia, the historical and contemporary oppressions of the ghost-figure, Antje, and the housekeeper, Magrieta, there is an ongoing inference that the narrator considers himself oppressed under the new regime. Ruben's thoughts and speech often represent the self-justifying rhetoric and despondency of a recently usurped locus of power for whom the future holds no promise. This is a new turn in the politics of South African oppression, in which the once-powerful now claim victimisation. Crucially, Ruben ultimately realises both his historical privilege and also his need to redeem himself; what is interesting, however, is the explication of white victimisation throughout the novel. If art is always on the side of the oppressed, as both Gordimer and Brink assert, then this focus on Ruben's 
experience suggests that he represents the newly oppressed group in a post-apartheid nation. Once again, consideration of the role of the newly empowered is avoided in favour of a focus on a newly 'oppressed' group. To signal Ruben's oppressed state is, of course, perilous, in that it aligns the experiences of the post-apartheid white group with the oppression of non-white South Africans under the apartheid regime a comparison which is clearly unsatisfactory in that it trivialises non-white oppression.

Throughout the text, Ruben is prompted to interrogate his past and to consider the present social and political realities in terms of this past; he soon realises that he has always been defined by his non-involvement. The most pertinent example of this type of avoidance of others and of his environment is his failure to assist his horrifically wounded friend and neighbour, Johnny MacFarlane, as he lies bleeding and gesturing frantically for help after a brutal attack. This incident demonstrates both the violence of the social environment, in which the previously oppressed overcome those who represent white oppressors, but also indicates the continued noninvolvement of the narrator in a post-apartheid society. Despite Ruben's selfjustificatory rhetoric, in which he claims he did not recognise his friend, the implications of the event are clear. The part Ruben played in the apartheid regime was that of a silent (as distinct from silenced) spectator. In this respect, his noninvolvement may no longer be used as a denial of his role as oppressor, but rather represents complicity, a (silent) endorsement of the regime and its oppressive practices.

Over the course of his life, Ruben has used books and libraries to shield himself from reality, avoiding the unpleasantness of the world. Libraries, in particular, represent an order and manageability impossible in the real world. Even after retirement, Ruben researches material for articles he admits it is unlikely he will write, attempting, by immersing himself in history, to retain some hold on a past order. However, in doing so, he also avoids the urgencies of the present. Ultimately, Ruben realises the incongruity of his actions: 
I'm beginning to lose my faith in making notes. Or is it just in my ability to face them, once made? For so many years I have done this to obtain a hold on my world, on the treacherous water of life running through my fingers. Frost's momentary stay against confusion. But the downside is that once it has been written down, irrevocably, on paper, one cannot pretend it has not happened. Even if the account is not reliable - or perhaps especially if it is not reliable? - it compels one to face it. (229)

Evidence in this text (and indeed in Brink's oeuvre as a whole) suggests that this type of (historical, social, moral and political) confrontation is necessary in order to survive the present. The role of the white group under a new order, it is implied, is to investigate the injustices of the past and to adopt both personal and social responsibility for that past. As in Brink's earlier texts, the guilt of white South Africans is assumed and the means by which to redress past injustices considered.

\title{
Hope
}

\author{
"“Kafka wrote somewhere [...] "There is hope. But not for us"" \\ 'Kafka is dead,' she said. 'We are here"' \\ (Kafka, no. ref. qtd. in Brink Rights 210).
}

The possibility of a peaceful and just future persists in Brink's oeuvre; there is a persistent glimmer of hope in each of the texts. Characters who suffer - whether in enslavement, or under apartheid - often look to a better future in which their children may live without suffering. Whether this hope is realisable, however, is uncertain. In a post-apartheid nation, Brink's characters continue to struggle in a violent and unjust society, and the promise of peace and prosperity appears elusive. Nevertheless, this text stubbomly upholds the promise of a better future signalled in each of the earlier novels; Ruben ponders,

how can I myself understand - that a desert holds the promise of flowers, that the dark of a moonless night is a condition of the light, that only in solitude can we discover the need of others, that even after a storm like the one outside 
the little birds can begin to sing? Yet it is something new. It is something I grew up with. The miracle of rain after three years of drought. The flowers bursting from the parched earth. The flying ants. (305)

The promise of hope, it is suggested, is inherent in the violence and despondency of the present day. This promise is not, however, inevitable, but depends on action: a better future is linked to the need for personal responsibility and action. So, when Ruben complains that, post-apartheid, "It's supposed to have changed", Tessa responds, "It's for us to make the change" (210). Again, Brink places any possibility of hope for a better future with the individual and her/his commitment to action.

Gordimer suggests that "The white writer has to make the decision whether to remain responsible to the dying white order - and even as dissident, if he goes no further than that position, he remains negatively within the white order - or to declare himself positively as answerable to the order struggling to be born" ("Living" 26). Textual evidence throughout Brink's oeuvre, and most specifically in this postapartheid novel, suggests that his sympathies and energies lie with the order being born. As in all of his works, Brink identifies and critiques the undesirable aspects of white South Africans and adopts responsibility, on behalf of his Afrikaner compatriots, for past injustices. While imagining the possibilities of a better future, Brink's post-apartheid texts do not evade the issues of the past, but instead suggest that resolution of the past is the only way to facilitate such a future.

\title{
Before I Forget
}

\author{
"My thousand and one nights have ended. \\ The stories now are over, finita la commedia. \\ My darling Scheherazade will have to wrap it up" \\ (Brink Before 305).
}

Brink's most recent novel, Before I Forget, is likewise obsessed with the past and its resolution. Rehearsing the same themes of earlier texts, this novel returns to 
past issues in an attempt to make sense of the present post-apartheid state, and of the implied author's role in that context. Revealingly, Chris Minnaar, the protagonist, is another of Brink's writer/narrators who shares many characteristics with Brink himself. While Chris recognises the problems and issues of his contemporary milieu, he returns to the well-rehearsed and familiar issues of the past in order to avoid confronting present day concerns. Chris offers a rendition of his life in which the many women of his past are aligned with key historical events in South Africa: "Every turn and convulsion and shiver of history over the last century," he claims, "I could mark with the memory of a woman" (296). Therefore, his narrative is a survey of both personal and national histories. This 'reading' of South African history is also set against contemporary media coverage of the Iraqi conflict. Inclusion of the US/Iraq conflict is clearly a new theme; however, the material is merely a new framework by which to compare the apartheid and post-apartheid conditions of South Africa - the thematic concerns remain those of previous novels. Tellingly, the 'novel' is figured as a collection of "notes" (9); as in previous novels such as States of Emergency, conventional form is rejected in favour of a more formless, stream of consciousness effect. The entire narrative device - in terms of content and form appears designed to address and revise key historical moments and themes. This results in a collection of memories which trace the highlights of a lifetime but refuse to coalesce into any one, solid claim. Like Brink's overall project, there is no trite or smug conclusion, but rather a welter of possibilities and frustrations - essentially, this novel is a summary of Brink's entire oeuvre - both this text and his work as a whole are part of a conversation concerning issues which affect the author. There are no definitive claims or concrete solutions, but rather dialogue and some tentative suggestions for a way forward.

The narrative may be understood as the implied author's attempt to resist death: "What else does one write for? What else could possibly drive us so? Whence this unnatural urge? To defy death, like Scheherazade?" (7). At the age of 78, he reflects on those he has loved and lost - either through various turns of his life, or in terms of death - while simultaneously both celebrating and lamenting the passing of 
his own life. His focus on the deaths of his elderly mother and his love, Andrea, foreground the sense of his own impending demise. In the context of the readings I have made of previous novels and of this one, the narrator's experience of writer's block reflects the feelings of paralysis experienced by dissident artists in a newly democratic state - what is the role for a dissenting voice in a newly 'free' society, the text implicitly asks? Disconcertingly - if the implied author is aligned with Brink himself - both Chris and Brink himself appear to have exhausted their material, and to despair at the possibility of any new and fulfilling role as dissident artists in this context. Arguably, the implied author's acknowledgement of his own mortality is aligned with Brink's acknowledgement that this phase of his writing life has come to an end. It appears there is no significant role for these artists to adopt in this realm they must merely live out their time and pass the role of dissent on to the next generation. There is a distinct tone of frustration and melancholy associated with the realisation that one's voice is no longer required.

This tone prompts further consideration of the role of dissent. In Brink's model of truth, it is the potential for contestation which is central - truth is an acknowledgment of subjectivity. However, in a democratic society, the potential for Brink's notion of truth is upheld within the democratic system and thus, there is no need for it to be articulated from outside. Therefore, with the apartheid government and its associated oppressive policies and practices defunct, the counter-discursive position becomes suddenly moot. Where certain historical conditions allow dissenting voices a particular authority, the removal of these conditions results in altered (or redundant) roles for dissidents. The tone of resignation found in this novel signals the time-bound nature of Brink's particular project. It is for this reason, I believe, that Brink's post-apartheid work has lost much of its fervour. In this most recent novel, in particular, the energy and force of his cyclical thematic concerns is largely absent. The only new insight offered in this novel is that discussed above that the authors (both implied and actual) have no further role as dissenting voices against an oppressive regime. In this respect, Before I Forget is both a record of what Brink has achieved and also a lament for the loss of his position as a dissident artist. 
There is also, however, a sense of release linked to the closure this text represents; as his protagonist reveals near the conclusion to Brink's most recent text,

This is it then. I cannot postpone it any longer; I am approaching the end. In the beginning, and all my life, I think, I believed that I was writing to hold on, not to let go, not to lose it all for ever. But [...] I know the opposite is true.

We do not write to hold on, but to let go. (306)

This is the cathartic aspect of Brink's literary project, to which I have previously referred. Narration of the brutalities and horrors of the apartheid regime represents not merely a protest against such injustices, but also a means by which victims, witnesses and, (potentially at least), perpetrators may be healed.

\section{Irresolution}

The flawed nature of The Rights of Desire and the 'recycled' nature of both this text and Before I Forget provide opportunity to reflect on similar flaws in earlier texts and on the tenor of Brink's work as an ongoing project. As I have demonstrated throughout the preceding chapters, Brink reworks his material continually, returning to central themes and considering certain aspects of his social and political milieu from new perspectives and with new knowledge. Each novel is a revisitation or reexamination and it is therefore useful to consider the texts not merely as independent entities but also as parts of the oeuvre entire. In this respect his oeuvre may be viewed as a developing project; each of the novels may be flawed and 'incomplete' in certain respects and yet, when viewed as a whole, the body of work represents a thorough and ongoing examination of Brink's environment and traces a developing political (specifically dissident) consciousness. The Rights of Desire and Before I Forget may not be particularly revelatory or significant interventions when read independently; however, in the context of the oeuvre, they provide useful demarcation points at which Brink reassesses his own position and that of the nation he describes. 
In the preceding discussion, I have examined Brink's works from a number of perspectives and in relation to a number of central themes. My approach in looking at the oeuvre from different perspectives is highly suggestive of the problem as it plays out for Brink: he has not been able to straightforwardly resolve the themes he treats, but has refused to give up or shy away from the central issues. Indeed, this is the very nature, and arguably the most interesting aspect, of his work, that Brink leaves things unresolved. In this way, he allows the possibility for future investigation, a further dialectic interrogation of the issues in a new context.

Rather than representing a linear progression from one idea to another, or from problem to solution, the oeuvre looks at various facets of the same issue, and revisits these. In each chapter, I introduced a text or a number of texts focussing on a central thematic concern and/or political context and using the novels as a means by which to consider not merely the literary treatment of that topic, but also the worldly implications of such treatment. The chapters look at Brink's various ways of treating dissident, anti-authoritarian politics. They provide a survey of his engagements with the novel form, tracing the ways in which he considered his questions about, and challenges to, authoritarianism. In every instance, I have endeavoured to relate both the literary examination and the related discussion to the specific historical and social milieu of the South African nation with which Brink is concerned. In this respect, I have followed Brink's own journey, tracing the ongoing cultural conversation in his work and attempting to plot various developments and inevitable failures in relation to his thematic and strategic concerns.

In the introduction, I provided an overview of the specific social and political contexts which flavour Brink's work. I addressed the nature and extent of the apartheid regime and described its implications in terms of both a societal milieu, and its representation in literature. The assessment of these contexts was intended to provide a framework against which Brink's literature may be compared and assessed. I also delineated the initial stirrings of literary dissent in the group of Afrikaans writers known as the Sestigers. This group, I claimed, signalled a cultural and 
literary revolution, a dissident stance with which Brink was intimately involved. Further, I considered the value of dissenting voices in oppressive realms and established an evaluative model by which Brink's works would be examined, emphasising that the social and political contexts in which the texts were created are as crucial a component as any other. I suggested that Brink's work may best be understood as a cultural conversation, in which the texts both speak of and respond to South Africa's specific social and political environments. Throughout my introductory remarks, I was concerned to emphasise the specifically dissident stance of Brink's work, and to state my intention to trace the development of this challenge over an historical period which encompasses (predominately) the apartheid era and also the recent years of the post-apartheid nation.

Overall, my examination of Brink's work traces Brink's developing political consciousness while simultaneously examining the politics of writing as dissident politics. It is a discussion concerning the effectiveness and potentially paradoxical nature of writing as a dissident project. Clearly, Brink's personal mandate is to write for the oppressed. Having discarded the prejudices of his Afrikaner upbringing, Brink stepped outside of his environment and committed to resistance versus authoritarianism.

Behind each of the claims described above, there is an overtly dissident intention, a challenge to prescription and prohibition and to the authorities responsible for such totalitarianism. This situation is the state of moral "siege" to which Brink refers. Throughout his texts, there is an emphasis on individual choice as a counter to prescriptive contexts - for Brink also, the power of choice is central. I made reference to Brink's claim that "the Greek word for 'heresy,' originally meant choice, which made of the heretic "one who chooses"' (qtd. in Miller 44). In these terms, Brink is clearly characterised as 'heretical'. Throughout the preceding discussion I have delineated the ways in which Brink's texts challenge his political environment in diverse ways, disrupting the truth claims of a prejudicial and unjust state and offering alternative truths under which a new society may arguably be 
negotiated. I have traced an increasingly overt dissidence in the texts, considered the effect of this position and discussed the reactions of the authorities (most specifically represented by the censors). Throughout, there has been an underlying assumption that not merely Brink's cause is just, but also the dissident stance itself; it has been assumed that political subversion is both necessary and just, that the dissidence with which Brink's texts are aligned is a moral and noble position. While I have interrogated aspects of this assumption as they arose in relation to specific topics, it is necessary to reconsider the question of dissidence in light of Brink's entire project.

Crucially, dissidence is defined as a breaking away from authority, a questioning of the status quo. Arguably, and problematically, dissident stances are not in themselves questioned or undermined, but rather assumed noble and moral positions against oppressive authorities. One must ask, on what basis is a dissenting position granted moral impunity? Surely dissidents are not precluded from (possibly unconscious) misuse or abuse of their position? They are as ideologically determined and confined as any other individual, and inevitably delimited by these factors; therefore, they cannot symbolise any 'purity', in terms of intent or motivation. Further, dissidents are mutually defined by an 'enemy' of some kind, a (usually dominant) individual or group considered oppressive, unjust, or wrong: clearly, this simplistic binary association - oppressor versus dissident - does not indicate the subtleties or complexities of relationships of this kind. To assume that a dominant group is invariably 'evil' or oppressive in some way is as perilous as it is to deem dissident causes inevitably just.

While I clearly sympathise with the anti-prejudicial position Brink adopts in his works, and with his dissent against an oppressive regime, I have also sustained a critique of Brink's own position. Mirroring Brink's own proclaimed intention to reassess his work and his role as an artist, I have attempted to identify the ways in which Brink succeeds in his subversive tactics, but also the various problems and failures which permeate his work. Brink's representation of women provides many pertient examples, suggesting that while Brink is clearly anti-prejudicial in his works, 
he also perpetuates many of the societal assumptions regarding women which ensure their continued subjugation. I have suggested that the representation of female subjects in Brink's oeuvre remains under construction. Likewise, the texts are often flawed in terms of the naiveté of their politics, or in respect to literary technique. Interestingly, it is in the texts' various flaws that some of the most valuable exegesis originates; Brink's arguably flawed account of various aspects of this milieu points to ideological and prejudicial factors of the author with which we all must contend. Of significant interest, however, is that Brink constantly attempts to 'correct' these 'errors' - he re-visions and retries, constantly. I contend that dissident positions are not inherently favourable, and that they must instead be judged by some evaluative model - in assessing Brink's own dissenting position, I believe I have identified an evaluative framework and determined the value of Brink's dissident project.

Throughout these discussions I have identified the ways in which Brink speaks both of and to his environment; often, this reference to a specific social and political context is framed in terms of a question, a suggestion or a mandate designed to impel others to action. In each instance, Brink actively engages his reader in the dialogue he initiates, compelling individuals to engage in the ongoing cultural conversation which characterises his work. The suggestion that Brink's work is engaged in this type of dialogue is central to my debate concerning the positions of dissident artists and of the value of those positions. If Brink's works were characterised by their endorsement of an alternative system of belief, a static truth designed to replace the apartheid monologue, then I would judge the dissenting position they upheld of little value. However, Brink's texts arguably attempt to perpetuate a series of mutable alternatives in order to contest static truth per se. Further, despite Brink's own problematic authoritative role as the creator of his texts, the cultural conversation therein invites participation from a number of sources. This invitation endorses the need for not one, but many, in negotiating narrative and truth. It suggests the relativity of truth and acknowledges the impossibility of static monolithic truth being representational. Brink's value as a dissenting voice, therefore, lies in his willingness to critique what he considers unjust, but also to 
continually interrogate his own stance. This self-interrogation is twofold, consisting of his own ongoing re-assessment of his work and also of an invitation to others to critique all claims, including his own. It is this process of self-interrogation which refutes many of the criticisms as to Brink's own authoritative and problematically delimited perspective. Brink's novels do not pretend to answer the problems of his age, or to redress the manifold injustices of the apartheid era, but rather raise concerns as to the inadequacies and problems of a particular social and historical milieu, posing some possible solutions, and leaving others largely unresolved. A common thread throughout Brink's texts is the posing of questions and the irresolution of these issues. Common to all the texts is a mandate to expose these issues, no matter how distasteful, and to encourage the individual reader's involvement in finding solutions.

My understanding of Brink's work as a developing project - rather than as a series of independent texts - has shaped my assessment of the oeuvre in substantial ways. Brink's (re)cycling of theme and content, I contend, is a central aspect of Brink's cultural conversation, a factor which counters, to some degree, many of the criticisms of his work. The various weaknesses I have identified in terms of both theme and technique are, I contend, crucial indicators of a process of development, the journey towards a more ideal conception. As in Brink's own use of the metaphor of journeying as a symbol of (self-) assessment, the texts as a whole represent a progression of both technique but also, most importantly, of Brink's philosophy. While the individual texts describe Brink's various (often flawed) depictions of and responses to his political and social milieus, the oeuvre as a whole traces a developing philosophy regarding the (ever-changing) South African situation; thus, as I have emphasised, it is crucial to consider the works as a complete project as the sum is clearly of greater significance than any individual novel.

I have delineated a number of failures in Brink's oeuvre thus far, suggesting aspects of his work which require further assessment on the part of the author. It is not, however, the success or otherwise of the individual texts or the project as a whole 
which is the sole determinate in assessing the value of Brink's work. Rather, one must also consider the dissident mandate behind the project. What is most interesting in respect to the oeuvre is that Brink lives in a politically intense and contentious time, and that he responds so willingly and courageously to this context. Despite his ethnic and cultural alignment with the Afrikaners responsible for the apartheid regime, Brink, significantly, broke away from the laager and inhabited an initially indeterminate and arguably still marginal position as a white dissident voice. Brink attempts, throughout his work, to investigate central issues from a variety of perspectives; however, the oeuvre centrally traces Afrikaner self-consciousness, the development of a social, political and historical consciousness. In his acknowledgement of the ideological implications of Afrikanerdom, Brink makes a willed decision to respond to these historical conditions. Admittedly, he is not always wholly successful in maintaining a politically correct stance within that dissident space, and yet his willingness to return, again and again, to that space is remarkable.

When the largest exemplar of authoritarianism - the apartheid state - fell, Brink sought another cause, adopting a feminist stance against gender prejudice; he saw feminism as another battle to be waged on behalf of the oppressed. This search for new causes continues; where does one turn one's attention when the battle against oppression has been waged? This is the overriding question both within and beyond Brink's oeuvre. Brink is so committed to a dissident stance that he appears unable to operate outside of this context. This is the situation reflected in the two novels discussed in this concluding chapter - it is clear that, post-apartheid, Brink is a crusader without a crusade. This is perhaps the central concern in dissident writing; the notion that the dissenting position relies on an authority of some kind to challenge. Brink's diagnosis of, and attempts to heal the diseased state depend on its continued ill health; when the problems of society are largely relieved, Brink's position as a dissenting voice become increasingly tenuous. Brink's later novels demonstrate his awareness of this authorial dilemma. Simultaneously, they illustrate that this is yet another issue which Brink clearly articulates, but which remains unresolved. 
The Rights of Desire, with which I introduced this concluding chapter, illustrates that Brink has not arrived at a static and certain position. This irresolution - often a deliberate attempt to resist fixity and conclusion, but sometimes representing merely the author's uncertainty - characterises his work. Rather than representing a 'lack' in the oeuvre, however, the irresolution signals instead the possibilities of further investigation, of an ongoing dialectic interrogation, Brink's cultural conversation. The recent publication of Before I Forget raises the question as to what this cultural conversation will address next. With the dissident position largely unavailable in a democratic milieu, Brink's next task appears to be to find a new theme and a new challenge for his work. Again, Brink returns to an unresolved aspect of his work; for the majority of his dissident career, Brink remained dedicated to challenge without resolving his difficult position as a dissenting voice or coming to any clear conclusion as to what exactly constitutes dissidence. While attaching himself, through his texts, to various causes such as the feminist one, Brink does not identify an ongoing niche for himself as a dissenting voice, except as he speaks on behalf of others. The return to male narrators in the last two novels under discussion points to an attempt to create a new position from which to raise a challenge against an oppressor of some kind; however, as I have argued, the victimhood Brink appends to the white male voice is unconvincing. Brink seems to be searching for a new mode of challenge but fails to find one.

The concluding paragraph of Before I Forget is pertinent in this regard:

I have to stop writing. It is the end. But it is never the end. I must go on living, that is not done yet. Yet nothing remains as it has been. For the first time I can imagine Don Giovanni old. He is still woman-struck, a man possessed by love and loving. The only difference is he no longer needs a camera. (311)

It is my sincere hope that these are not the final words from Brink, but rather a hiatus while he searches for new inspiration and direction, a new means by which to continue his cultural conversation. However, it is my contention that, like his texts, 
Brink himself was a product of his times; his dissident stance was the result of a particular set of social, political and now clearly historical, circumstances. Now that these contexts have shifted so dramatically, it is difficult to imagine Brink's next reincarnation as a dissident artist; the likelihood is that, like many notable dissenting voices, Brink's will inevitably fall silent. 


\section{APPENDIX \\ Photographs selected from \\ A Portrait of Woman as a Young Girl}

"She cannot be said"

(Brink Portrait n. pag.). 


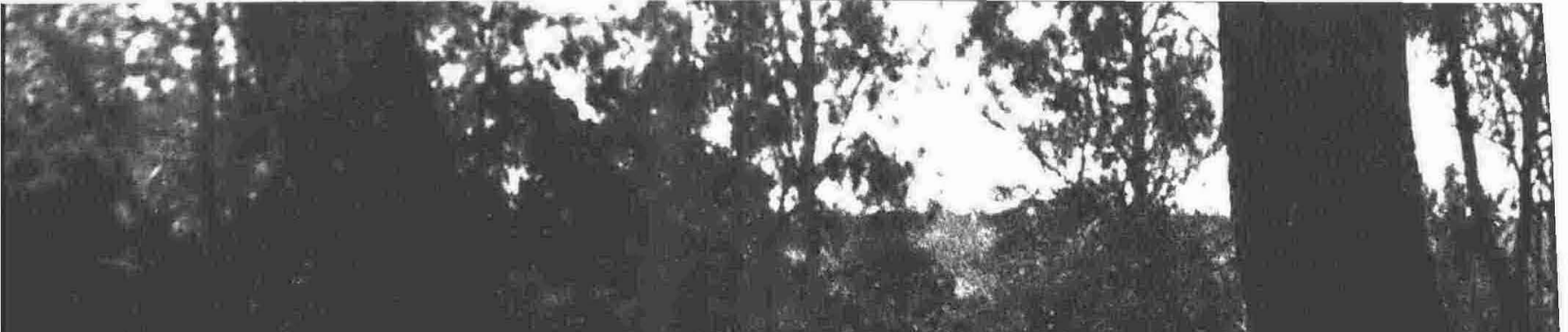

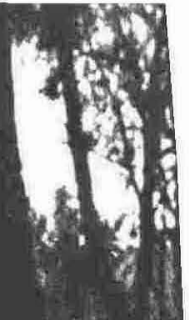

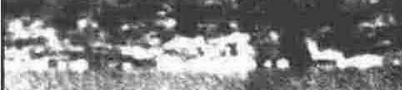

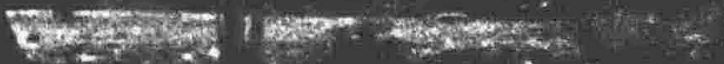
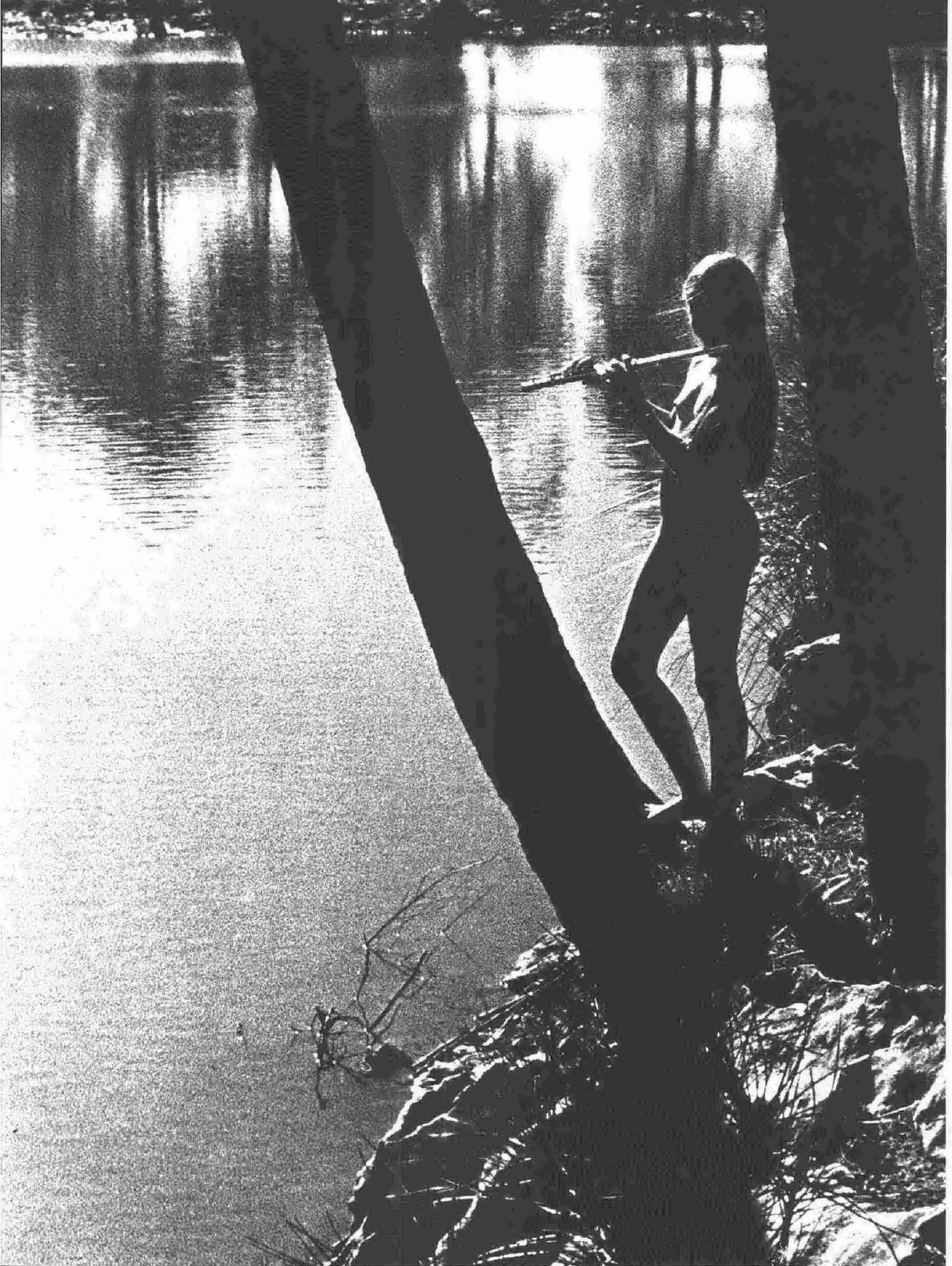


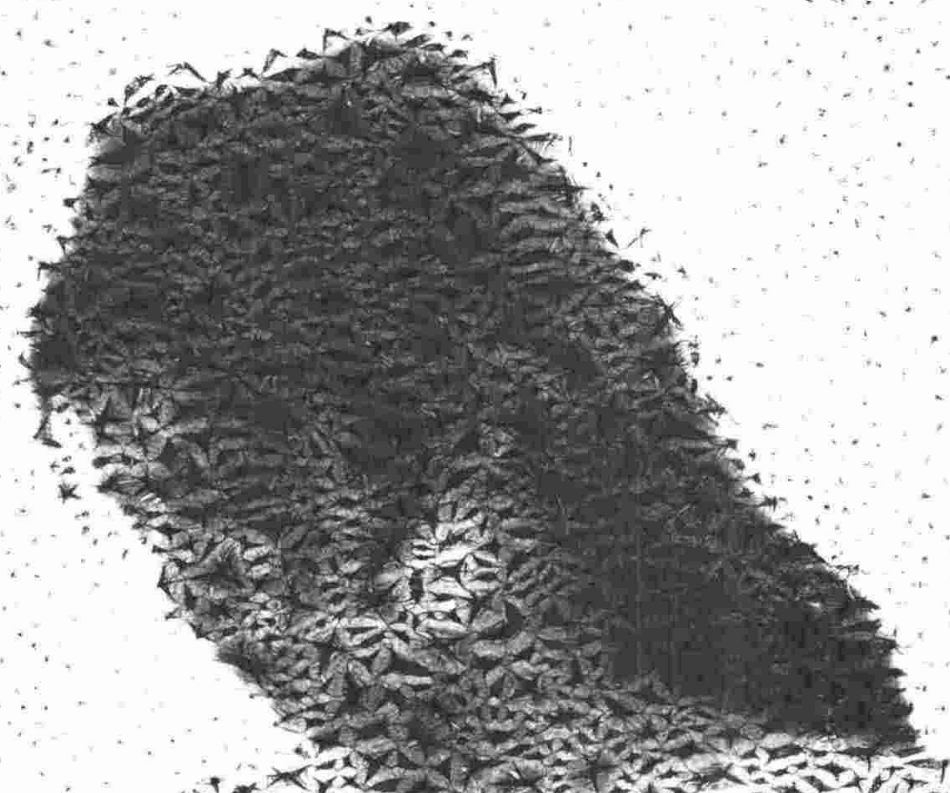

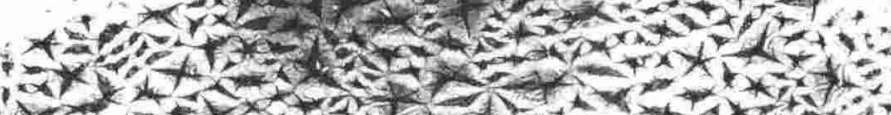

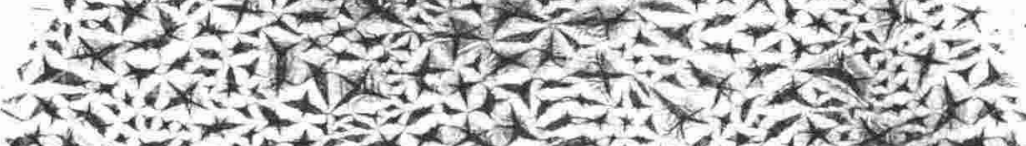

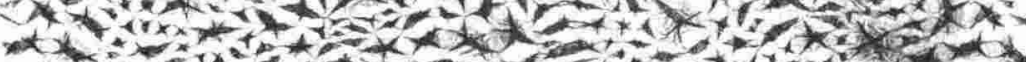

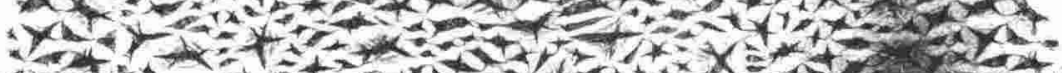

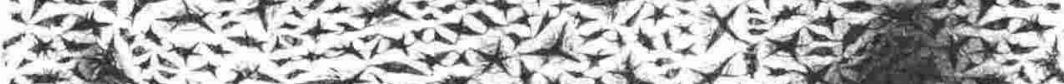

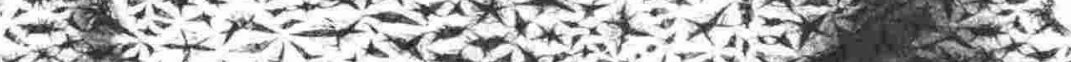

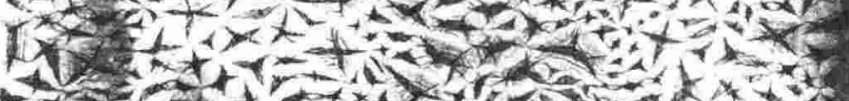

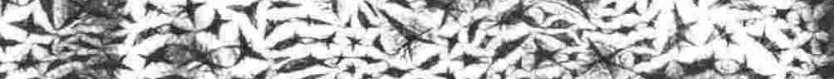

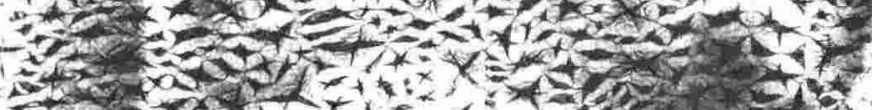

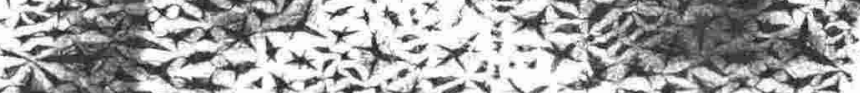

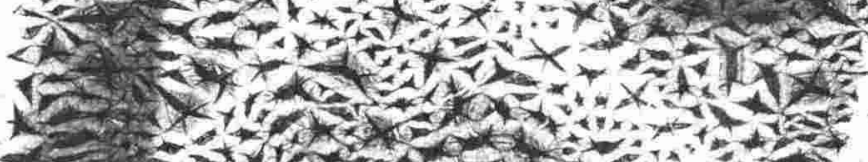

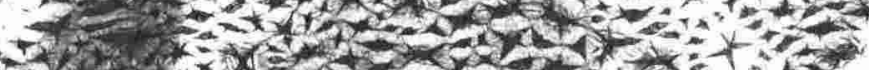

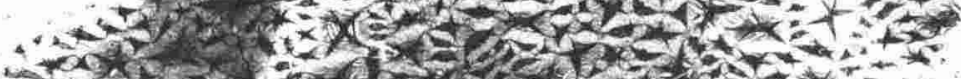

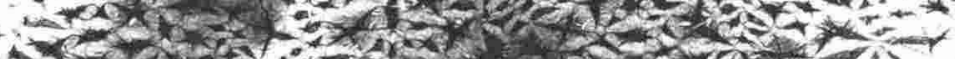

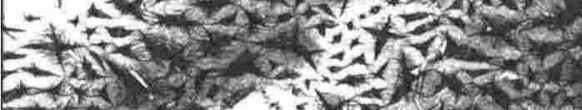

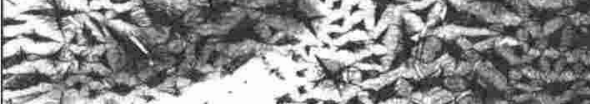

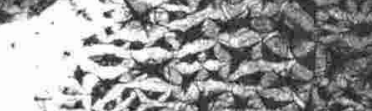

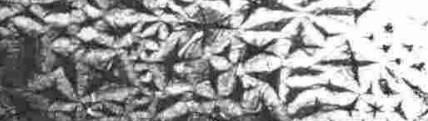

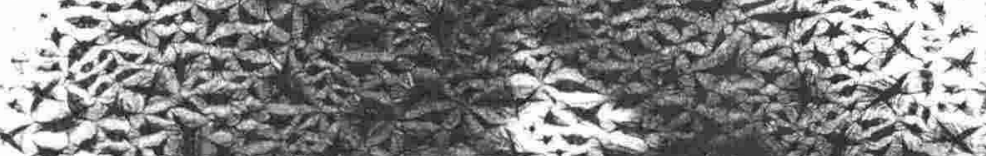

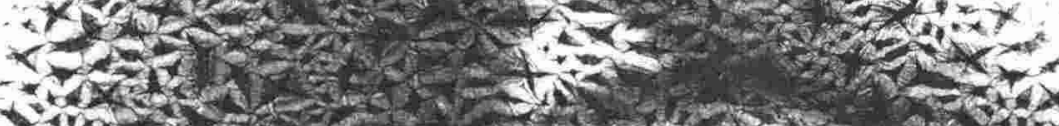

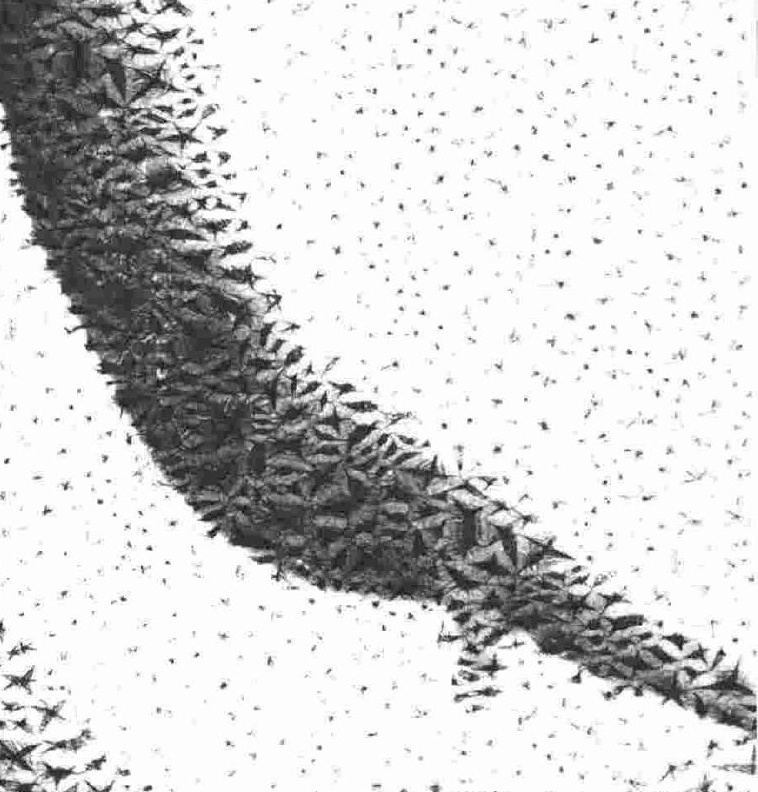

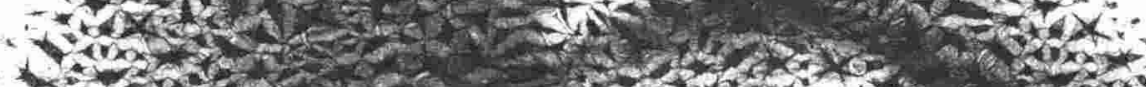

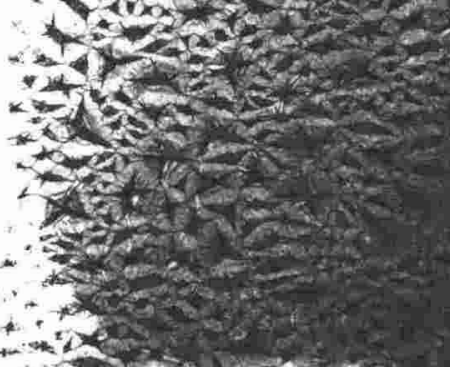

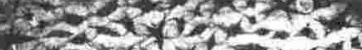

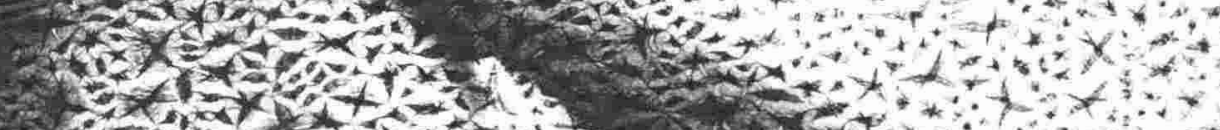

$0000+2+3 x^{2}+4 x+x$

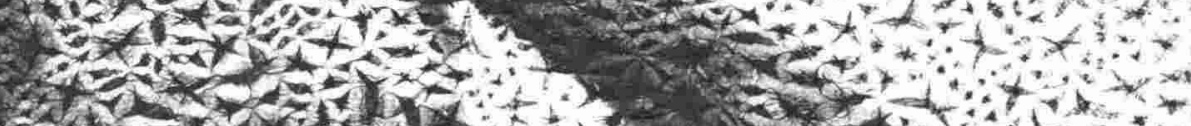
is

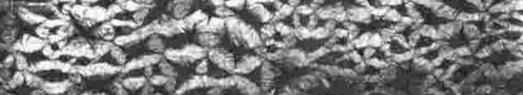




\section{Works Cited}

Anderson, Benedict. Imagined Communities: Reflections on the Origin and Spread of Nationalism. London: Verso, 1986.

"André (Philippus) Brink." Major Twentieth Century Writers. Vol. 1. Ed. Bryan Ryan. London: Gale Research, 1991. 386-87.

Attwell, David. "Confession and Double Thoughts: Tolstoy, Rousseau, Dostoevsky (1985)." Doubling the Point: Essays and Interviews. Cambridge, Massachusetts: Harvard U P, 1992. 251-93.

Ayling, Ronald. "André Brink." Dictionary of Literary Biography: South African Writers. Ed. Paul A Scanlon. Vol. 225. Detroit: Gale Group, 2000. 42-72.

Barkan, Elazar. The Guilt of Nations: Restitution and Negotiating Historical Injustices. New York: W. W. Norton, 2000.

Barthes, Roland. "The Death of the Author." Image-Music-Text. (1977): 142-48.

--.. The Pleasure of the Text. Trans. Richard Miller. London: Johnathan Cape, 1976.

Baudrillard, Jean. Simulations. Trans. Paul Foss, Paul Patton \& Philip Beitchman. New York: Semiotext(e), 1983.

Beekman, Jan F. "The First National Conference in Censorship." Critical Arts. 1.2 (June 1980) 42-6.

Berlin, Isaiah. Russian Thinkers. London: The Hogarth Press, 1978.

Bevan, David. "Introduction." Literature and Exile. Ed. David Bevan. Amsterdam: Rodopi, 1990. 3-4.

Birley, Robert. "Freedom of the Press." Index on Censorship, 5.1 (1976): 32-40.

Boehmer, Elleke. "Speaking from the Periphery." Third World Quarterly. 11.1 (1989): 162-66.

Borges, Jorge Luis. Labyrinths. 1964. New York: Penguin, 1970.

Breytenbach, Breyten. "Conflict and Literature in South Africa." End Papers. 1974. London: Faber, 1986. 77-86.

---. The True Confessions of an Albino Terrorist. London: Faber, 1984.

Brink, Andre. Before I Forget. London: Secker \& Warburg, 2004.

--. An Act of Terror: A Novel. London: Secker \& Warburg, 1991.

---. "After Soweto." Writing in a State of Siege: Essays on Politics and Literature. Asahi Journal. Tokyo, 1976. New York: Summit, 1983. 128-53.

---. The Ambassador. 1963 Afrik. 1964, 1967 Engl. London: Faber, 1985.

--. "André Brink." Interview. Writing against Apartheid: South African Authors Interviewed by Dieter Welz. 1987. Grahamstown: National Literary Museum, 1989. 55-61.

--.. "André Brink Talks to Bahgat Elnadi and Adel Rifaat." Interview. UNESCO Courier. (1993): 4-8.

--.. "The Arts in Society." Reinventing a Continent: Writing and Politics in South Africa. Keynote Lecture, Winter School, Grahamstown Arts Festival, July 1987. Massachusetts: Zoland, 1998. 47-58.

---. "The Breytenbach File." The New Review. 3.25 (1976): 3-8.

--.. "Censorship and Literature." Writing in a State of Siege: Essays on Politics and Literature. Censorship, South African Institute of Racial Affairs, Johannesburg, 1982. New York: Summit, 1983. 231-56.

---. "Censorship and the Author." Critical Arts. 1.2 (1980): 16-26. 
---. A Chain of Voices. London: Faber, 1982.

---. Devil's Valley: A Novel. 1998. London: Vintage/Random, 2000.

---. A Dry White Season. 1979. London: Minerva, 1997.

---. "The Failure of Censorship." They Shoot Writers, Don't They? Index on

Censorship 1980. Ed. George Theiner. London: Faber, 1984. 142-49.

---. File on a Diplomat. 1963 Afrik. 1964 Engl. Trans. André Brink. London: Longmans, 1967.

--.- The First Life of Adamastor. 1993. London: Vintage/Random, 2000.

---. "The Hour of the Idiots." Reinventing a Continent: Writing and Politics in South Africa. Der Stern, October 1986. (In slightly shortened form). Massachusetts: Zoland, 1998. 25-46.

---. "Imagining the Real." Writing in a State of Siege: Essays on Politics and Literature. Introduction to discussion on "Myth in Literature" at the International Writers' Reunion, Lahti, Finland, June 1981. New York: Summit, 1983. 215-22.

---. Imaginings of Sand. 1996. London: Vintage/Random, 2000.

---. An Instant in the Wind. 1976. London: Vintage/Random, 2000.

---. "The Intellectual and His World." Writing in a State of Siege: Essays on Politics and Literature. Graduation Ceremony Address, University of Witwatersrand, Johannesburg, April 1980. New York: Summit, 1983. 196-203.

---. "Interrogating Silence: New Possibilities Faced by South African Literature." Writing South Africa: Literature, Apartheid, and Democracy, 1970-1995. Eds. Derek Attridge and Rosemary Jolly. Cambridge: Cambridge U P, 1998. 1428.

---. "Interview." Interview with Hans Neervoor. Bzzlletin (1989).

--.. "An Interview with André Brink by Jim Davidson." Interview. Overland 94/95 (1984): 24-30.

---. "Introduction." Reinventing a Continent: Writing and Politics in South Africa. Massachusetts: Zoland, 1998. 1-12.

---. "Introduction: A Background to Dissidence." Writing in a State of Siege: Essays on Politics and Literature. New York: Summit, 1983. 13-35.

---. "Literature and Offence." Writing in a State of Siege: Essays on Politics and Literature. Philosophical Papers. 5(1) Rhodes University, Grahamstown, 1976. New York: Summit, 1983. 116-27.

-.-. "Literature as Cultural Opposition." Reinventing a Continent: Writing and Politics in South Africa. Paper delivered at a seminar on "Literature as a Political Force", Salzburg, July 1993. Massachusetts: Zoland, 1998. 185-202.

--.. Looking on Darkness. 1974. London: Vintage/Random, 2000.

---. "Mahatma Gandhi Today." Writing in a State of Siege: Essays on Politics and Literature. The Gandhi Memorial Lecture delivered at the Phoenix Settlement, Durban, October 1970. New York: Summit, 1983. 54-70.

---. "Mapmakers." Writing in a State of Siege: Essays on Politics and Literature. 43rd International PEN Congress, Stockholm, May 1978, incorporating material from talk at Cape Town Book Fair, April 1980. New York: Summit, 1983. 163-71. 
---. "Nadine Gordimer." They Shaped Our Century: The Most Influential South Africans of the Twentieth Century. Cape Town: Human \& Rousseau, 1999. 266-70.

-.-. "'No Way out": 'Sizwe Bansi Is Dead" and the Dilemma of Political Drama in South Africa." Twentieth Century Literature. 39.4 (1993): 438-54.

---. "Of Slaves and Masters." Writing in a State of Siege: Essays on Politics and Literature. Argus. Cape Town, January 1978. New York: Summit, 1983. 15462.

---. "On Culture and Apartheid." Writing in a State of Siege: Essays on Politics and Literature. Study Project on Christianity in an Apartheid Society, Spro-cas Publications 1 Johannesburg, 1970. New York: Summit, 1983. 71-95.

---. On the Contrary: Being the Life of a Famous Rebel, Solier, Traveller, Explorer, Reader, Builder, Scribe, Latinist, Lover and Liar. 1993. London: Minerva/Reed, 1994.

---. The Other Side of Silence. London: Secker \& Warburg, 2002.

---. A Portrait of Woman as a Young Girl. Cape Town: Buren Publishers, 1973.

---. "The Position of the Afrikaans Writer." Reality. (1971): 12-15.

---. "Reflections on Literature and History." Reinventing a Continent: Writing and Politics in South Africa. De Balie, Amsterdam, Symposium on "Collective Memory", 1990. Massachusetts: Zoland, 1998. 133-43.

---. "Reimagining the Past: André Brink in Conversation with Reingard Nethersole." T'kama-Adamastor: Inventions of Africa in a South African Painting. Ed. Ivan Vladislavic. Johannesburg: U of the Witwatersrand, 2000.

--.. "Reimagining the Real: English South African Fiction Now." Reinventing a Continent: Writing and Politics in South Africa. Paper read at the Winter School of the Grahamstown Festival of the Arts, July 1992. Massachusetts: Zoland, 1998. 145-63.

--.- "Reinventing a Continent." Reinventing a Continent: Writing and Politics in South Africa. Written 1995. World Literature Today, Winter 1996. Massachusetts: Zoland, 1998. 229-45.

---. "Reinventing a Continent (Revisiting History in the Literature of the New South Africa: A Personal Testimony)." World Literature Today. 70.1 (1996): 17-23.

---. Reinventions: Old Literature; New Climates. New York: Delos/William Drenttel, 1996.

---. The Rights of Desire: A Novel. London: Secker \& Warburg/Random, London 2000.

---. Rumours of Rain. 1978. London: Flamingo/Fontana, 1984.

--- "South Africa: Postmodernism in Afrikaans and English Literature." International Postmodernism: Theory and Literary Practice. Eds. Hans Bertens and Douwe Fokkema. Amsterdam: John Benjamins, 1997. 483-90.

---. "Speaking in Voices." Reinventing a Continent: Writing and Politics in South Africa. Le Matin. Paris, June 1982. Massachusetts: Zoland, 1998. 13-20.

---. States of Emergency. 1988. London: Flamingo/Fontana, 1989.

--. "Stories of History: Reimagining the Past in Post-Apartheid Narrative." Negotiating the Past: The Making of Memory in South Africa. Eds. Sarah Nuttall \& Carli Coetzee. Oxford: Oxford U P, 1998. 29-42. 
---. "Summer, Sun and Sapphire: A Tribute to Sestiger Publisher Daantjie Saayman." Leadership. 16.1 (1997) Online edition. 28 November 2002.

<www.leadership.co.za/issues/1997july/articles/dantjie.html>

---. "Transgressions: A Quantum Approach to Literary Construction." Journal of Literary Studies. 1.3 July (1985): 10-26.

---. The Wall of the Plague. Faber, Great Britain, 1984. London: Continental Flamingo/Fontana, 1985.

---. "The Writer in a State of Siege." Writing in a State of Siege: Essays on Politics and Literature. Paper read at AGM of Afrikaans Writers' Guild, Durban, July 1979. New York: Summit, 1983. 172-95.

-.-. "Writers and Writing in the World." Writing in a State of Siege: Essays on Politics and Literature. Collation of two lectures delivered at the University of Natal, Pietermaritzburg and Durban, July 1969. New York: Summit, 1983. 41-53.

---. "Writing against Silence." Writing in a State of Siege: Essays on Politics and Literature. Speech on Brink's acceptance of the Martin Luther King Memorial Prize for A Dry White Season, London, April 1980. New York: Summit, 1983. 204-07.

Brooks, Libby. "My Inner Woman." Promotion for The Other Side of Silence. Mail \& Guardian Online 13 September 2002. 28 November 2002. $<$ http://www.chico.mweb.co.za/art/2002/2002sep/020913-inner.html >.

Camus, Albert. The Plague. 1947. Trans. Stuart Gilbert. 1948. Harmondsworth: Penguin, 1960.

Carter, Paul. Living in a New Country: History, Travelling and Language. London: Faber, 1992.

Cervantes, Miguel de Saavedra. The Ingenious Hidalgo Don Quixote de la Mancha. 1605. New York: Penguin, 2001.

Chait, Sandra. "Mythology, Magic Realism, and White Writing after Apartheid." Research in African Literatures. 31.2 (2000): 17-28.

Chapman, Michael. "The Problem of Identity: South Africa, Storytelling and Literary History." New Literary History. 29.1 (1998): 85-99.

Coetzee, Ampie. "Afrikaans Literature in the Service of Ethnic Politics?" Afrikaans Literature: Recollection, Redefinition, Restitution: Papers Held at the 7th Conference on South African Literature at the Protestant Academy, Bad Boll. Eds. Robert Kriger and Ethel Kriger. Amsterdam: Rodopi, 1996. 103-09.

Coetzee, Cryil. "Introducing the Painting." T'kama-Adamastor: Inventions of Africa in a South African Painting. Ed. Ivan Vladislavic. Johannesburg: U of the Witwatersrand, 2000.

Coetzee, J. M. "André Brink and the Censor." Research in African Literatures. 21.3 (1990): 59-74.

---. "The Novel Today." Upstream. 6.1 (1988):2-5.

---. White Writing: On the Culture of Letters in South Africa. New Haven: Yale U P, 1988.

Conrad, Joseph. Heart of Darkness and Other Tales. 1902. Oxford: Oxford U P, 1996. 
Cope, Jack. The Adversary Within: Dissident Writers in Afrikaans. Cape Town/New Jersey/London: David Philip/Humanities Press/Rex Collings, 1982.

de Jong, Marianne De. "The Morality of Historiography and the Immorality of the Sestigers." Journal of Literary Studies. 13.1/2 (1997): 246-53.

de Lange, Margreet. "Afrikaans Authors and Censorship." The Muzzled Muse: Literature and Censorship in South Africa. Amsterdam: John Benjamins, 1997.

de Waal, Shaun. "A Time for New Imaginings." Mail \& Guardian. 17-23 May 1996 1996: 3-4.

Defoe, Daniel. A Journal of the Plague Year. 1722. Trans. G. A. Aitken. London: Dent, 1908.

Derrida, Jacques. Dissemination. La Dissémination. Paris: Editions du Seuil 1972. Trans. Barbara Johnson. London: Athlone, 1981.

Dhlomo, H. I. E. "Valley of a Thousand Hills." Collected Works. Eds. N. Visser and T. Couzens. Johannesburg: Ravan Press, 1985.

Diala, Isidore. "Biblical Mythologies: Apartheid and Anti-Apartheid Readings." Alternation. 6.2 (1999): 35-49.

---. "Nadine Gordimer, J. M. Coetzee and André Brink: Guilt and Expiation and the Reconciliation Process in Post-apartheid South Africa". Journal of Modern Literature. 25.2 (2004).

---. "The Political Limits of (Western) Humanism in André Brink's Early Fiction." Studies in the Novel. 34.4 (2002): 422-48.

Dixon, Shelley M. "Personal and National Knowledge in André Brink's South Africa." AULLA XXXII Knowledge and Nation. Victoria University, Wellington, New Zealand,: unpublished, 2003.

---. "Shouting against Silence: André Brink's Voices of Truth." M. A. Wellington, New Zealand: Victoria University of Wellington, 2002.

---. "Stories or History?: Female Counter-Narratives in André Brink's Imaginings of Sand." AUMLA 101 (May 2004): 39-70.

Driver, Dorothy. "Women and Nature, Women as Objects of Exchange Towards a Feminist Analysis of South African Literature." Perspectives on South African English Literature. Eds. Michael Chapman, Colin Gardner and Es'kia Mphahlele. South Africa: Ad Donker, 1992.

Dubow, Saul. Scientific Racism in Modern South Africa. Cambridge: Cambridge U P, 1995.

Dugard, John. Human Rights and the South African Legal Order. Princeton, New Jersey: Princeton U P, 1978.

Echevarría, Roberto González. "Introduction" The Ingenious Hidalgo Don Quixote de la Mancha. Miguel de Saavedra Cervantes. 1605. New York: Penguin, 2001.

Foucault, Michel. Discipline and Punish. 1977.

--.. "Don Quixote in the Lettered World." Critical Essays on Cervantes. Ed. Ruth El Saffar. Boston, Massachusetts: G. K. Hall \& Co., 1986. 117-21.

Freeman, Mark. Rewriting the Self: History, Memory, Narrative. London: Routledge, 1993.

Gallagher, Susan VanZanten. A Story of South Africa: J M Coetzee's Fiction in Context. Cambridge, Massachusetts: Harvard U P, 1991. 
Galloway, Francis. "Breyten Breytenbach." They Shaped Our Century: The Most Influential South Africans of the Twentieth Century. Cape Town: Human \& Rousseau, 1999. 125-29.

Gilman, Sander L. Difference and Pathology: Stereotypes of Sexuality, Race, and Madness. Ithaca: Cornell U P, 1985.

Goldblatt, John. "A Glimmer from the Gloom." Index on Censorship. 4.1 (1975): 95, 97.

Gordimer, Nadine. "Apartheid and the Primary Homeland." Index on Censorship. 1.3-4 (1972): 26.

---. "English-Language Literature and Politics in South Africa." Aspects of South African Literature. Ed. Christopher Heywood. New York/London:

Heinemann/Africana Publishing, 1976. 99-120.

---. "The Essential Gesture." The Essential Gesture: Writing, Politics and Places. The Tanner Lecture on Human Values, U of Michigan, 12 October 1984.

Published in The Tanner Lectures on Human Values Ed. Sterling M. McMurrin (Salt Lake City, Utah: U of Utah P; Cambridge: Cambridge U P; 1985), and in a slightly different version, Granta, n15 (Spring 1985): 135-51. Ed. Stephen Clingman. London: Penguin, 1989. 285-300.

---. "Living in the Interregnum." The Essential Gesture: Writing, Politics and Places. Given as the William James Lecture, New York U Institute of the Humanities, 14 October 1982. 1st published in slightly different version New York Review of Books. v29, n21 \& 22, 20 (January 1983): 21-2, 24-9. Ed. Stephen Clingman. London: Penguin, 1989. 261-84.

---. "Selecting My Stories." The Essential Gesture: Writing, Politics and Places. Introduction to Selected Stories (London: Johnathan Cape, 1975; New York: Viking, 1976). Ed. Stephen Clingman. London: Penguin, 1989. 111-17.

Graeber, Laurel. "Let Everyone Speak at Once." The New York Times Book Review. July 2519931993 , sec. 7:23.

Gurnah, Abdulrazak. "Prospero's Nightmare." Times Literary Supplement. New York, 1993. 21.

Hassall, A. J. "The Making of a Colonial Myth." Review of International English Literature. 18.3 (1987): 3-28.

Herndon, Gerise. "From Rue Cases-Nègres to a Dry White Season: The Evolution of Resistance in Euzhan Palcy's Film." Beyond Survival: African Literature and the Search for New Life. Vol. 5. Trention, N. J.: Africa World Press, 1999. 233-41.

Hofmeyer, Isabel. "Building a Nation from Words: Afrikaans Language, Literature and Ethnic Identity, 1902-1924." The Politics of Race, Class and Nationalism in Twentieth-Century South Africa. Eds. Shula Marks and Stanley Trapido. London/New York: Longman, 1987. 95-123.

Honderich, Ted, ed. The Oxford Companion to Philosophy. Oxford/New York: Oxford U P, 1995.

Hugo, Vitor. Napolean Le Petit. 1852.

Hutcheon, Linda. A Poetics of Postmodernism: History, Theory, Fiction. New York: Routledge, 1988.

Jacobs, J. U. "Naming a Crisis: André Brink's States of Emergency." Nomina 
Africana, (4) 1990. 35-48.

Jameson, Fredric. The Political Unconscious: Narrative as a Socially Symbolic Act.

New York: Cornell U P, 1981.

Jolly, Rosemary Jane. Colonization, Violence, and Narration in White South African

Writing: André Brink, Breyten Breytenbach, and J. M. Coetzee. Ohio: Ohio U P, 1996.

Joseph-Vilain, Mélanie. "Writing Women Back into History: Magic Realism in Andre Brink's Imaginings of Sand". Commonwealth Essays and Studies. 26.1 (2003): 61-70.

Keenan, John. "André Brink." The Good Book Guide Magazine (March 1996): 3.

Kerby, Anthony Paul. Narrative and the Self. Bloomington: Indiana U P, 1991.

Kolocotroni, Vassiliki, and Olga Taxidou."A Dry White Season: The Personal and the Political." Cinema and Fiction: New Modes of Adapting, 1950-1990. Eds. John Orr and Colin Nicholson. Edinburgh: Edinburgh U P, 1992. 39-53.

Kossew, Sue. "The Anxiety of Authorship: J. M. Coetzee's the Master of Petersburg (1994) and André Brink's on the Contrary (1993)." English in Africa. 23.1 (1996): 67-88.

-.-. Pen and Power: A Post-colonial Reading of J. M. Coetzee and André Brink. Amsterdam: Rodopi, 1996.

---. "Reinventing History; Reimagining the Novel: The Politics of Reading André Brink's Imaginings of Sand." Journal of Literary Studies. 13.1/2 (1997): 11326.

---. "Resistance, Complicity and Post-Colonial Politics." Critical Survey. 11.2 (1999): 18-30.

Krog, Antjie. Country of My Skull. London: Vintage, 1999.

Krupnick, Mark. "Introduction: Derrida and Displacement." Displacement, Derrida and After. Ed. Mark Krupnick. Bloomington: Indiana U. P., 1983. 1-17.

Kundera, Milan. "Comedy Is Everywhere." They Shoot Writers, Don't They? Ed. George Theiner. London: Faber, 1984. 150-56.

Levett, Ada Elizabeth, and Adolphus Ballard. The Black Death on the Estates of the See of Winchester: With a Chapter on the Manors of Whitney, Brightwell, and Downton. Oxford: Clarendon Press, 1916.

Llosa, Mario Vargas. "Love Finds a Way." The New York Times Book Review. 51 (1993) 1, 23-4.

Malan, Charles. "Introduction: Race and the Writer." Race and Literature (Ras En Literatuur). Ed. Charles Malan. Pinetown, South Africa: Owen Burgess, 1987. 2-11

Malraux. La Condition Humaine. 1933.

Mansfield, Nick. Subjectivity: Theories of the Self from Freud to Haraway. Cultural Studies. Eds. Terry Threadgold, Rachel Fensham \& John Tulloch. St Leonard's, N. S. W.: Allen \& Unwin, 2000.

McHale, Brian. Postmodernist Fiction. London: Routledge, 1987.

McNiven, Ian J, Lynette Russell, and Kay Schaffer, eds. Constructions of Colonialism: Perspectives on Eliza Fraser's Shipwreck. London/New York: Leicester U P, 1998.

Memmi, Albert. The Colonizer and the Colonized. Boston: Beacon, 1965. 
Merrett, Christopher. A Culture of Censorship: Secrecy and Intellectual Repression in South Africa. Cape Town: David Philip, 1994.

Microsoft. The Concise Columbia Encyclopedia. 1996-97. CDROM. Columbia U P.

Miller, Chris, ed. The Dissident Word: The Oxford Amnesty Lectures 1995. New York: Basic, 1996.

Millin, Sarah Gertrude. God's Step-Children. 1924. London: n. p., 1927.

Mofolo, Thomas. Chaka: An Historical Romance. 1931. Trans. Daniel P. Kunene. London: Heinemann, 1967.

Mohamed, Abdul R. "The Economy of Manichean Allegory: The Function of Racial Difference in Colonialist Literature." Critical Inquiry. 12.1 (1985): 59-87.

Moi, Toril. Sexual/Textual Politics: Feminist Literary Theory. London: Routledge, 1985.

Moyana, T. T. "Problems of a Creative Writer in South Africa." Ed. Christopher Heywood. Aspects of South African Literature. London/New York: Heinemann/Africana, 1976, 85-98.

Nuttall, Sarah, and Carli Coetzee, eds. Negotiating the Past: The Making of Memory in South Africa. Oxford: Oxford U P, 1998.

Ommundsen, Wenche. Metafictions?: Reflexivity in Contemporary Texts. Melbourne: Melbourne U P, 1993.

Ormond, Roger. The Apartheid Handbook. Middlesex: Penguin, 1985.

Parry, Benita. "Speech and Silence in the Fictions of J. M. Coetzee." Writing South Africa: Literature, Apartheid, and Democracy, 1970-1995. Eds. Derek Attridge \& Rosemary Jolly. Cambridge: Cambridge U P, 1998. 149-65.

Paton, Jonathan. The Land and People of South Africa. Portraits of the Nations. N. p.: Harper Collins, 1990.

Peleg, Ilan, ed. Patterns of Censorship around the World. Colorado: Westview, 1993.

Petzold, Jochen. "André Brink and the Alternative Past" Re-Imagining White Identity by Exploring the Past: History in South African Novels of the 1990s. Trier: Wissenschaftlicher Verlag Trier, 2002, ?

Plaatje, Sol. T. The Boer War Diary of Sol. T. Plaatje. Ed. J. L. Comaroff. Johannesburg: Macmillan, 1973.

---. Mhudi. 1930 Ed. Stephen Gray. Lovedale: Lovedale Press; London/Washington D. C.: Heinemann/Three Continents Press, 1978.

---. Native Life in South Africa. 1916. Johannesburg: Ravan Press, 1982.

Plummer, Robert. "New Past for Old." Southern African Review of Books, 1996. 910. Vol. 8.

Renders, Luc. "Voices from the Past: The Depiction of the Khoisan in Contemporary Afrikaans Historical Novels." Mots Pluriels 13 (2000).

Roberts, Sheila. "Inheritance in Question: The Magical Realist Mode in Afrikaans Fiction." Postcolonizing the Commonwealth: Studies in Literature and Culture. Ed. Rowland Smith. Ontario: Wilfrid Laurier U P, 2000. 87-97.

Ryan, Ray T., and John de Smidt. Cape Town: Scenic City of the South. Cape Town: Purnell \& Sons, 1979.

Schaffer, Kay. In the Wake of First Contact: The Eliza Fraser Stories. Cambridge: Cambridge U P, 1995.

Shakespeare, William. "Romeo and Juliet." 1595. Ed. A. J. J. Ratcliff. London: 
Thomas Nelson \& Sons, n. d. 211.

Sheckels, Theodore F. Jr. The Lion on the Freeway: A Thematic Introduction to

Contemporary South African Literature. New York: Peter Lang, 1996.

Slemon, Stephen. "Unsettling the Empire: Resistance Theory for the Second World."

World Literature Written in English. 30.2 (1990): 30-41,

Stein, R, Conrad. Enchantment of the World: South Africa. Chicago: Children's

Press, 1986.

Todorov, Tzvetan. The Conquest of America: The Question of the Other. Trans.

Richard Howard. New York: Harper and Row, 1982.

Toerien, Barend J. "South Africa." Ed. André Brink. World Literature Today. 53.

(1979): 549.

Tutu, Desmond. "Nothing Short of a Miracle." The Right to Hope. Ed. Catherine

Thick. London: Earthscan, 1995. 1-3.

van Rooyen, J. C. W. Censorship in South Africa: Being a Commentary on the

Application of the Publications Act. Cape Town: Juta \& Co., 1987.

van Wyk Smith, M. Grounds of Contest: A Survey of South African English

Literature. Jutalit, South Africa: Jutalit, 1990.

Viljoen, Louise. "Civilization and Wilderness: Colonial Spatial Binaries and the

Construction of Contemporary South African Identity in André Brink's An Instant in

the Wind and Kirby Van Der Merwe's Klapperhaar Slaap Nooit Stil Nie (One Can

Never Sleep Quietly on a Coir Mattress)". Storyscapes: South African Perspectives

on Literature, Space and Identity. Eds. Hein Viljoen and Chris Van der Merwe. New

York: Lang. 2004. 137-53.

Waugh, Patricia. Metafiction: The Theory and Practice of Self-conscious Fiction. Ed. Terence Hawkes. London: Methuen, 1984.

Weschler, Lawrence. Calamities of Exile: Three Nonfiction Novellas. Chicago: U of Chicago P, 1998.

Wheatcroft, Geoffrey. "A Talk with André Brink." Interview. New York Times Book Review. 13 June 1982, ed., sec. 7: 14-16.

White, Patrick. A Fringe of Leaves. London: Johnathan Cape; Vintage/Random, 1976.

Worthington, Kim L. Self as Narrative: Subjectivity and Community in Contemporary Fiction. 1996. Oxford: Clarendon Press, 2001.

Wren, Christopher S. "Apartheid's Children: Afrikaner Writers Today." The New York Times Book Review (1992): 1, 29-30.

Wroe, Nicholas. "Out of the Laager" Guardian Unlimited Online Saturday 14 August, 2004. 12 January, 2006.

$<$ http://books.guardian.co.uk/review/story/0,12084,1282495,00.html\#article continue>.

Young, Robert. White Mythologies: Writing History and the West. London: Routledge, 1990. 